\title{
LEAKAGE FROM WASTE TANK 16 AMOUNT, FATE, AND IMPACT
}

W. L. POE

\section{Contributors}

J. W. FENIMORE

J. H. HORTON

I. W: MARINE

W. E. PROUT
NOTICE

This report was prepared as an account of work sponsored by the United States Government. Neither the United States nor the United States Energy Research and Development Administration, nor any of their employees, nor any of their contractors, subcontractors, or their employees, makes any warranty, express or implied, or assumes any legal warranty, express or impility or responsibility for the accuracy, completeness or usefulness of any information, apparatus, product or process disclosed, or represents that its use would not infringe privately owned rights.

Publication Date: November 1974

Approved by

B. C. Rusche, Director

Environmental Sciences Section

\section{E. I. du Pont de Nemours \& Co. Savannah River Laboratory}

Aiken, S. C. 29801

PREPARED FOR THE U. S. ATOMIC ENERGY COMMISSION UNDER CONTRACT ATI07-21-1

This document is 


\section{DISCLAIMER}

This report was prepared as an account of work sponsored by an agency of the United States Government. Neither the United States Government nor any agency Thereof, nor any of their employees, makes any warranty, express or implied, or assumes any legal liability or responsibility for the accuracy, completeness, or usefulness of any information, apparatus, product, or process disclosed, or represents that its use would not infringe privately owned rights. Reference herein to any specific commercial product, process, or service by trade name, trademark, manufacturer, or otherwise does not necessarily constitute or imply its endorsement, recommendation, or favoring by the United States Government or any agency thereof. The views and opinions of authors expressed herein do not necessarily state or reflect those of the United States Government or any agency thereof. 


\section{DISCLAIMER}

Portions of this document may be illegible in electronic image products. Images are produced from the best available original document. 


\begin{abstract}
On September 8,1960 , a small amount of high activity waste leaked from Tank 16 at the Savannah River Plant and reached the surrounding soil. Calculations based on the measured ground water flow velocities, estimated flow paths, and the measured ion exchange capabilities of soil samples indicate that the radionuclides that leaked into the ground will decay before reaching the nearest creek, and thus will have no effect on the public.

Intensive investigation and monitoring since 1960 confirm that only a few tens of gallons of waste entered the soil. This waste contained 7.4 curies of radionuclides $\left(85^{1}{ }^{137} \mathrm{Cs}\right)$ per gallon. The radioactivity in the leaked waste reached the ground water almost immediately, but has moved only a few feet since 1960. The radioactivity level in the ground water fifteen feet from the edge of the concrete construction pad under Tank 16 is about ten times background, and between $2 \times 10^{-4}$ and $4 \times 10^{-4}$ curies of radioactivity have moved beyond this point. No radioactivity increase has been observed in wells $1700-2800$ feet from this tank.
\end{abstract}




\section{CONTENTS}

Introduction ................

Summary .................. . 11

Tank Construction ............. 15

Tank Leakage . . . . . . . . . . . . 20

Initial Leakage of Primary Vessel . . . . . . 20

Rationale for Continued Use of Leaking Tanks . . . 21

Steel Annulus Pan Overfill . . . . . . . . . . 22

Inleakage of Waste into Annular Space . . . . . . 34

Fate of Leaked High Activity Waste in SRP Soils.$\cdot 37$

Hydrology of the Waste Tank Farms . . . . . . 37

Waste Composition ............... 49

Quantitative Description of Radioactivity Migration

in Soils ............... 53

Application to Tank 16 Leak . . . . . . . . 58

Evaluation and Conclusions . . . . . . . . 61

References................ 71

Appendices

A - Chronology of Tank 16 Leakage and Detection

B - Extended Monitoring Program

C - Factors Influencing Migration of Radionuclides in SRP Soils

D - Inspection to Establish Cause of Waste Tank Leakage

E - Water Table Elevation

F - Reversal of Ground Water Gradient 


\section{LIST OF TABLES}

Table

$\underline{\text { Page }}$

1. Radioactive Constituents of Tank 16 Supernate . . 26

2. Analyses of Waste from Tank 16 . . . . . . 26

3. Samples from Tank 16 Annulus . . . . . . . . 36

4. Chemical Composition of H-Area High Activity Waste . . . . . . . . . . . . 50

5. Physical Properties of Aged Waste........ . 50

6. Low Concentration Nonradioactive Constituents of H-Area Supernate . . . . . . . . 51

7. Radioactive Constituents of H-Area Supernatant Waste... . . . . . . . . 51

8. Ground Water Flow. . . . . . . . . . 59

A-1. Analyses of Waste from Tank 16 . . . . . . . A-6

A-2. Radioactivity of Ground Water One Foot from Tank 16 . . . . . . . . . . . . . A-16

A-3. Radioactivity in Core Samples from Dry We11 Boring............ . A -25

A-4. Samples from Tank 16 Annulus - February 1972 . A-29

B-1. Statistical Analysis of Ground Water Radioactivity $15 \mathrm{ft}$ from and $10 \mathrm{ft}$ below Construction Pad . . . . . . . . . . B-12 


\section{LIST OF FIGURES}

Figure Page

1. Waste Storage Tank 16 . . . . . . . . . . . 15

2. Water Addition System . . . . . . . . . . . 17

3. Detail of Lower Section of Waste Tank . . . . . . . 19

4. Waste Level in Tank 16 Annulus . . . . . . . . 23

5. Waste Tank 16 Leakage . . . . . . . . . . 23

6. Waste Tank 16 Leakage Details . . . . . . . . 25

7. Radioactivity Located above Construction Pad . . . 29

8. Radioactivity of Ground Water above Construction Pad. . . . . . . . . . . . . . 29

9. Radioactivity of Ground Water Pumped from We11 6 above Construction Pad . . . . . . . . . 30

10. Radioactivity Removed from Water Addition System . 31

11. Radioactivity of Ground Water below Construction Pad ................... . 33

12. Ground Water Radioactivity below Construction Pad . 34

13. Waste Tank 16 Annulus Inspection. . . . . . . . . 35

14. Surface Formations and Drainage at the Savannah River Plant . . . . . . . . . . 38

15. Generalized NW to SE Geologic Profile across the Savannah River Plant... . . . . . 38

16. Hydrostatic Head in Ground Water Near H Area . . 39

17. Flow in Tuscaloosa Aquifer. . . . . . . . . . 41

18. Surface Water Table Contour Map with Water Flow Route . . . . . . . . . . . . . . 42

19. McBean Water Pressure Contour with Water Flow Route ................ . . 45

20. Congaree Water Pressure Contour with Water Flow Route .. . . . . . . . . . . . . 45

21. Soil Profile near Tank 16 . . . . . . . . . 46

22. Location of Ground Water Flow Velocity Measurements ............. . 47

23. Probability Curve . . . . . . . . . . . . 55 


\section{LIST OF FIGURES (CONTINUED)}

Figure

$$
\text { it... }
$$

24. Contaninant Front Profile ....

25. Section of Waste Tank 16 Encasement . . . . . 61

26. Radioactivity Removed from Water Addition System . 69

27. Elution Characteristics of Ion Exchange Media . . 69

A-1. Photograph of Initial Leakage - Tank 16. . . A A-2

A-2. TV Image of Initial Leakage - Tank $16 \ldots . .$. A-4

A-3. Construction We1d $X-R a y$ of Point of Initial Leakage - Tank $16 \ldots \ldots \ldots \ldots \ldots \ldots$. . . . . . . . . . .

A-4. Waste Leve1 in Tank 16 Annulus. . . . . . . A-8

A-5. Waste Tank 16 Leakage . . . . . . . . A -9

A-6. Waste Tank 16 Leakage Details . . . . . . A-10

A-7. Existing Ground Water Monitoring Wells . . . . A-11

A-8. Wells Five Feet from Tank $16 \ldots \ldots$. . . . . 12

A-9. Ground Water Radioactivity . . . . . . . . A-14

A-10. Circumferential Wells Surrounding Tank $16 \ldots$. . A-15

A-11. Wells to Determine Leak Path to We11.6..... A-17

A-12. Water Addition System Under Tanks 13, 14, 15, and 16 . . . . . . . . . . . . A-18

A-13. Radioactivity Removed from Water Addition System A-19

A-14. We11s to Detérmine Horizontal Movement and Water Table Drawdown . . . . . . . . . . A-21

A-15. Leak Areas below South Annulus Access Port of Tank 16, February 1961 . . . . . . . A A-22

A-16. Deep Wells . . . . . . . . . . . . A-24

A-17. Tank 16 Annulus Inspection of February 10, 1972 A-28 


\section{LIST OF FIGURES (CONTINUED)}

Figure

$\underline{\text { Page }}$

B-1. Ground Water Radioactivity Sampled above Construction Pad. . . . . . . . . . . . . B-2

B-2. Wells above Construction Pad. . . . . . . . . . B-3

B-3. Ground Water Radioactivity above Construction Pad. . . . . . . . . . . . . . . B-4

B-4. Wells below Construction Pad. . . . . . . . B-6

B-5. Ground Water Radioactivity below Construction Pad. . . . . . . . . . . . . B-7

B-6. Ground Water Radioactivity from Wel1 2. . . . . B-8

B-7. Ground Water Radioactivity $15 \mathrm{ft}$ from and $10 \mathrm{ft}$ below Construction Pad - North and West Sides . . B-9

B-8. Ground Water Radioactivity $15 \mathrm{ft}$ from and $10 \mathrm{ft}$ below Construction Pad - North and South Sides. . B-10

B-9. Ground Water Radioactivity $15 \mathrm{ft}$ from and $10 \mathrm{ft}$ below Construction Pad - North and East Sides . . B-11

B-10. H-Area Monitoring We1ls 1700-2800 ft from

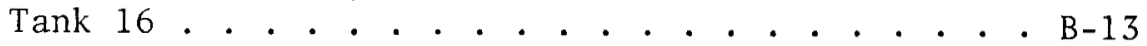

B-11. Ground Water Radioactivity $1700-2800 \mathrm{ft}$ from Tank 16 . . . . . . . . . . . . . B-13

C-1. Sorption of Various Cations by SRP Soils. . . . C-3

C-2. Possible Configurations of the Crystal Lattice of Mica Materials . . . . . . . . . . . C-5

C-3. Movement of Simulated Waste in Soil . . . . . C-8

C-4. Penetration of Soil by Simulated Waste. . . . . C-9

D-1. Face Map of Tank 16 Wall (1962 Inspection). . . D-3

D-2. Tank 16 Primary Wa11, by Periscope, 1962. . . . . D-4

D-3. Tank 16 Primary Wa11, by Periscope, 1972. . . . . D-4

D-4. Leak Point in a Vertical Seam Weld of Tank 16 Prior to Sandblasting . . . . . . . . . . D-6

D-5. Periscope Inspection of Sandblasted Vertical We1d, Access Hole 151 . . . . . . . . . . D-7 


\section{LIST OF FIGURES (CONTINUED)}

Figure

$\underline{\text { Page }}$

D-6. Leak Deposits around Crack across Vertical Weld . D-8

D-7. Same Area as Figure D-6, after Sandblasting . . . . D-9

D-8. Composite Photograph of Crack Shown in Figure D-7 . D-10

D-9. Sample Removed from Wall of Tank 16 . . . . . . D-11

D-10. Photomicrograph of Sample from Wall of Tank 16 . . D-13

D-11. Photomicrograph of Sample of Tank 16 Wall Showing Area near Arc Strike . . . . . . . . . D-14

D-12. Photograph of Sample of Tank 16 Wa11

Showing Numerous Cracks on Inner Surface . . . . D-14

E-1. Water Table Level around Waste Tanks . . . . . . E-2

E-2. Water Table Level Measuring Wells . . . . . E-3

F-1. Location of Ground Water Level Monitoring Wells . F-2 


\section{INTRODUCTION}

Radioactive waste from the chemical processing of nuclear reactor products at the Savannah River P1ant is stored in large tanks buried near the ground surface. Each tank has multiple containment barriers designed to prevent leakage to the surrounding soil and ground water. Tanks have been constructed as needed since plant operations began in 1954, and currently 30 such tanks (with a capacity of 31 million gallons) contain 20 million gallons of radioactive waste.

The only known incident in which waste leaked through the multiple containment of a waste tank at SRP occurred at Tank 16 on September 8, 1960. Tank 16 is constructed with a steel tank, or primary containment vessel, resting in a shallow steel pan, or saucer (see illustration). A massive concrete encasement surrounds the tank and pan. In effect, the pan is a liner for the concrete encasement. Any leakage through the steel tank wall is collected in the pan in the annular space between the steel tank and concrete encasement.

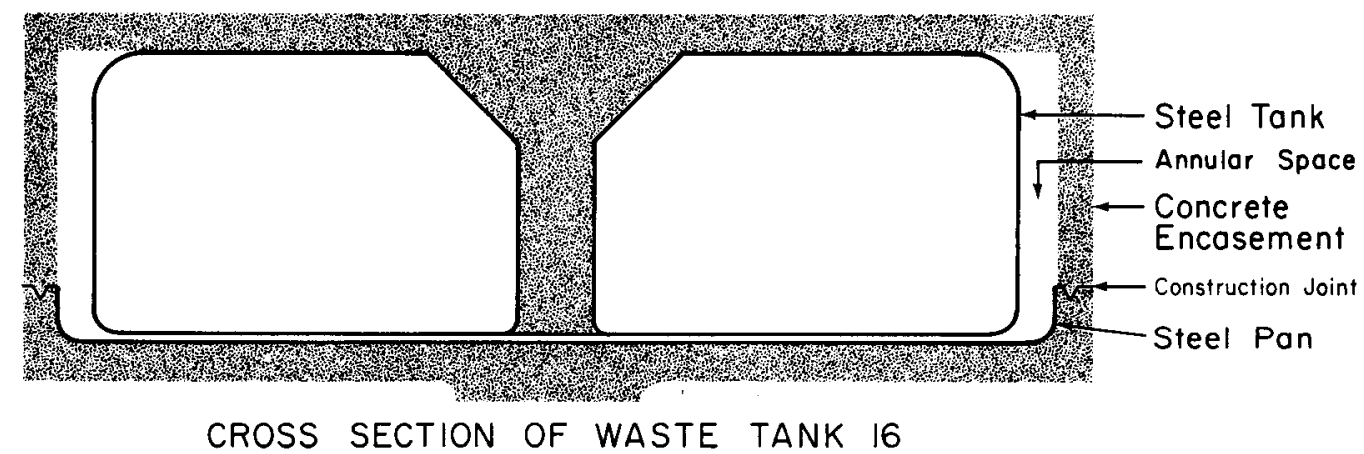

Slow leakage through cracks in the steel tank wall of Tank 16 was first observed in November 1959. Leakage increased rapidly in early September 1960 and overfilled the pan in the annular space on September 8. Some waste leaked through the concrete encasement before the contents of the annular space could be pumped to another tank six hours after the overfill. The amount of waste that leaked to the surrounding soil and ground water was not directly measured. Intensive investigations and monitoring efforts over the intervening years have confirmed that only a few tens of 
gallons of waste containing up to a few hundred curies of radioactivity likely entered the soil.

The purpose of this report is to assemble in one place the available information on the leak, to give the best estimate of the amount of waste that leaked into the soil, and to estimate the fate and impact of the leakage. Such a report is practical now because of the accumulated data and observations conducted over the 14-year period and because of the growing knowledge of waste technology, much of which has evolved subsequent to the leak. As part of the continuing development in waste management, the causes of the leaks ${ }^{1}$ in the primary containment of this tank have been established, and newer tanks are built to an improved design. ${ }^{2-4}$ 


\section{SUMMARY}

A maximum of 700 gallons of waste rose above the top of the steel secondary containment pan of Tank 16 for about six hours on September 8, 1960. The precise amount of waste that leaked through the thick-walled concrete encasement, which contairs the tank and pan, and into the soil is not known, but monitoring of the area indicates some radioactivity did escape the containment structures. Most of the 700 gallons was contained within the annular space by the concrete encasement, and was transferred to Tank 14 on September 8,1960 . (This transfer to Tank 14 plus others made during the next month totaled 185,000 gallons that leaked from the tank into the annulus.) Based on available information, a few tens of gallons of waste may have leaked into the soil. The waste contained 7.4 curies of radionuclides $\left(85 \%{ }^{137} \mathrm{Cs}\right)$ per gallon.

Since the tank bottom is below the water table, the radioactivity that escaped from the concrete encasement reached the ground water almost immediately, but it has moved only a few feet in the ensuing 14-year period. The slow movement results from placement of the waste tank farm in an area of very low flow of the ground water and from the ion exchange capacity of the soil. Monitoring the ground water in the area surrounding the tank confirms that radioactivity movement is quite slow. Calculations based on the measured ground water flow velocities and estimated flow paths and the measured ion exchange capabilities of the soil determined in laboratory samples indicate that the leading edge of the radionuclides should not reach the nearest creek and thus ultimately the populated area for $1 \times 10^{5}$ to $8 \times 10^{5}$ years.* Movement of the "core" or central section of the radionuclides would be delayed and should require $2 \times 10^{5}$ to $12 \times 10^{5}$ years* to reach the populated area. In any of these time periods, all of the radiocesium would have decayed, leaving harmless solutions of stable barium. The above calculations assume that climatic conditions, hydrology, and ground water usage remain unchanged during the periods covered by the calculation. In times as long as hundreds of thousands of years, some of these conditions might change. If these conditions were assumed to remain unchanged for a hundred years or so, and then the radioactivity from this leak was released to the creek by some mechanism, or if the radioactivity moved at the same rate as the ground water (travel time of 70-350 years), the concentration of radionuclides in the creek from this release would be below the concentration guide limit for cesium in drinking water.

* The range of times denotes the range of uncertainty in travel path to the creek. 
The present information suggests that overfill of the secondary containment pan in September 1960 resulted in leakage of waste into the ground at several locations with each individual leak being relatively small (probably the equivalent of a few gallons of waste). This judgment is based on the following observations:

- Multiple areas with low level of radioactivity were found around the circumference of the tank soon after the annulus pan overfill.

- Construction details of the tank would make seepage from several points around the periphery of the tank more likely than a single large leak.

- No point with high levels of radioactivity, but several with low levels of radioactivity, were found after the annulus pan overfill.

- The reaction of alkaline waste with clay particles of soil would cause the clay particles to disperse and plug the soil thus limiting the amount of leakage in a given area.

- The one area of leakage detected by the water addition system (an interconnected drain field under the bottom of the waste tank) is estimated to have contained about 1-2 gallons of waste.

- At the expected slow rate of radioactivity movement, only those leaks that could channel to a monitoring well have probably been detected.

Knowledge of the details of the tank construction and sequence of the annulus pan overfill suggests that the amount of waste that could have leaked from the tank was small. The short duration ( 6 hours) of the overfill of the secondary containment pan, low head (maximum of 1-1/2 inches if no leakage occurred), and tight construction of the concrete encasement suggest also that the volume of waste that could have leaked immediately to the soil was small. Waste that leaked into cracks and that could later seep into the soil was estimated to be a maximum of about 16 gallons.

Similar knowledge of the tank construction details indicates that the most likely path of waste leakage to the soil through the concrete encasement was a horizontal construction joint around the circumference about five feet above the bottom of the tank. This joint is probably not as watertight as the monolithic pour of either the upper or lower side walls of the concrete encasement. Leakage through this joint would probably be a seeping, 
not a free flowing, leak. Under this condition, a waste holdup cavity within the tank encasement would be required if many gallons of waste were to leak from the tank. The construction joint itself might serve as this cavity with a maximum estimated holdup capacity of 16 gallons provided it was an average of $1 / 32$ inch wide around the tank circumference. The assumed 1/32 inch wide crack in the construction joint is probably larger than the actual crack.

Based on soil ion exchange characteristics measured in laboratory-sized samples, assumed homogeneous soil, and area hydrology, the leading edge (containing less than $1 \%$ of the cesium and strontium activity) would be expected to have moved less than 10 feet in the 14 years since the annulus pan overfill. The center of the radionuclide deposit would have traveled less than 0.1 foot. The ion exchange data used in these calculations do not consider the effects of cesium fixation by weathered mica in the soil nor soil dispersion due to chemicals in the waste and the resulting flow restriction. Both of these would reduce the rate of movement of the radionuclide (or radionuclides).

Conditions conducive to channeling of ground water and thus more rapid flow have been observed in similar soils. A major effort to locate areas of ground water channeling in the vicinity of the waste tanks was made. Soil permeabilities ranged only a factor of ten, and statistical analyses of the permeability data indicate that regions of higher permeability would be rare. If the radioactivity were channeling at ten times the average flow rate, the distance moved since the leak would be expected to be less than 100 feet for the leading edge and 1 foot for the center.

Wells drilled 15 feet from the edge of the concrete construction pad (35 feet from the outer edge of the tank) have shown a slight increase in radioactivity to about 10 times background during the 14-year time interval since the leak. This tends to confirm the calculated slow movement rate of radionuclides discussed above. Between $2 \times 10^{-4}$ and $4 \times 10^{-4}$ curies of radioactivity from the tank have moved more than 15 feet from the edge of the construction pad. We1ls that are 1700-2800 feet from the waste tank and are part of the SRP environmental monitoring network have shown no radioactivity increase. No radioactivity levels above concentration guide limits for cesium in uncontrolled areas have been measured beyond the concrete construction pad. With this slow movement, it will be many centuries before this radioactivity will find its way to the creek, and by that time the radioactivity would have decayed.

Radioactivity was leached from one area of leakage, which must have been near the water addition system, and was drawn to the 
water addition system by extracting water from this system by pumping. Radioactivity recovered from this leak area during the ensuing years indicates the leakage was slightly greater than one gallon of waste. 5.6 curies of cesium was removed from this system (most of the cesium was recovered, and the water transferred to the seepage basins), and an estimated $0.8 \mathrm{Ci}$ migrated from the system with the ground water, primarily between 1962 and 1974. Based on the change of concentration of the radioactivity from the water addition system, calculations show that $\sim 0.6 \mathrm{Ci}$ remains in the area of the leak. Detection of radioactivity in the water addition system almost immediately after the September 8 incident probably indicates that the leak occurred in an area that channeled to the water addition system.

The decision was reached to remove Tank 16 from service in 1972 as a result of continued deterioration of the tank walls. The November 1971 inspection, part of the continuing waste tank inspection program at SRP, showed that the salt deposits on the primary containment wall were thicker and more numerous than before, indicating continued seepage. The tank (with an estimated 350 leak sites) was emptied except for the sludge heel in March 1972 as a first step in retirement. 


\section{TANK CONSTRUCTION}

This section briefly describes the design and construction of Tank 16 and the three other tanks constructed at the same time with emphasis on parts of the tank that are thought to be significant in understanding the leakage of this tank.

Tank 16 was one of four waste tanks constructed in $\mathrm{H}$ Area in 1955. Figure 1 shows the structure of these four waste tanks. The basic specifications for these tanks are as follows:
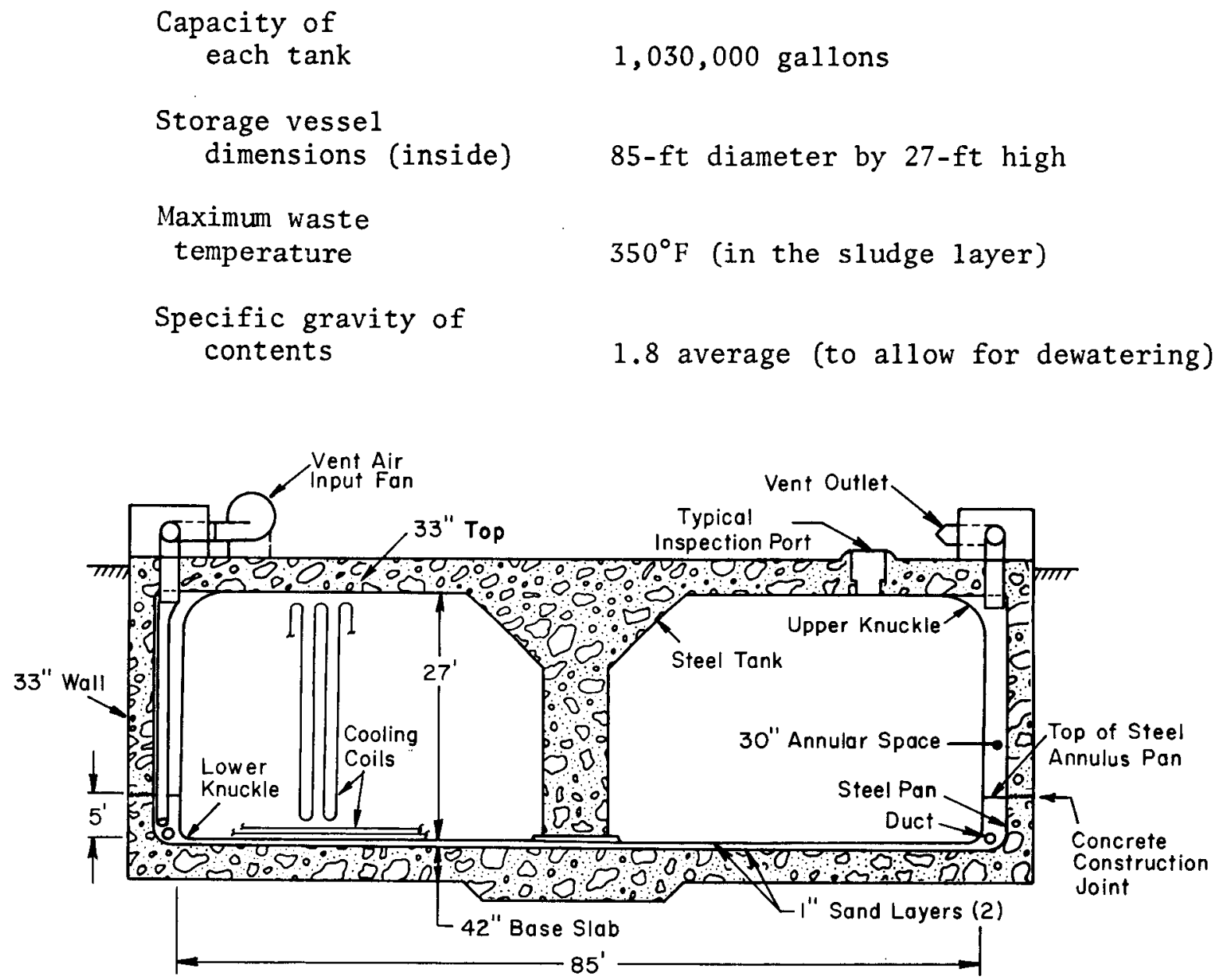

FIG. 1 WASTE STORAGE TANK 16 
The elevation selected for the tank was influenced by several factors: water table level, radiation shielding, blast resistance, hazard from tank or fill line leakage, and economics. The elevation of the tanks was as high as possible to minimize the depth the tank extended into the water table.

The installation of these tanks was preceded by a drilling exploration intended to determine the type of earth, load bearing capacity, the presence of cavities in the soil, and the profile of the water table. The tank substructures were built on undisturbed earth.

A soil hydration water addition system was installed beneath the tanks to prevent uneven drying of the ground due to heat from waste in the tanks. Dehydration could cause soil shrinkage and settling of the waste tanks. The water addition system consists of a grid of loose-jointed 4-inch drain tiles, with five risers to grade for introduction of water. The tiles are placed in two-foot-deep by two-foot-wide trenches, which are in a square pattern (see Figure 2) under all four tanks.

A 6-inch concrete construction pad was installed over the entire four-tank area. The pad extended some 20 feet beyond the edge of the tanks and provided a hard working surface for construction equipment. Photographs made during tank construction show cracks in the pad, some of which had been repaired.

The tank base slabs were constructed on the 6-inch concrete construction pad. These base slabs are reinforced concrete 42 inches thick near the edges increasing to 64 inches under the center column.

The secondary container, a saucer-shaped steel annulus pan, was constructed on the concrete base slab. The pan is approximately 90 feet in diameter and 5 feet high. When construction of the pan was complete and the pan was determined to be leak free, it was raised, and the concrete tank base was thoroughly cleaned. A layer of sand was spread and screeded to a uniform depth of 1 inch. This sand was contained by a continuous ribbon of "Sika-Igas."* Then the pan was lowered onto the layer of sand, compressing the "Sika-Igas."

A 6-inch by 4-inch stiffener angle was welded to the top of the steel annulus pan to ensure rigidity of the top of the steel pan. The 6 -inch dimension of the angle is in the horizontal plane and the 4-inch leg extends downward.

* U. S. Registered Trademark of Sika Chemical Corp, , Lyndhurst NJ. It is a black non-meltable mastic manufactured from blends of refined asphalts, resins, and plasticizing compounds reinforced with long-fiber asbestos. 
Lead flashing was installed in the concrete encasement side wall four inches above the top of the steel annulus pan and brought down and wrapped around the stiffener angle. The flashing diverts any water that might leak into the concrete vault into the steel annulus pan.

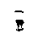

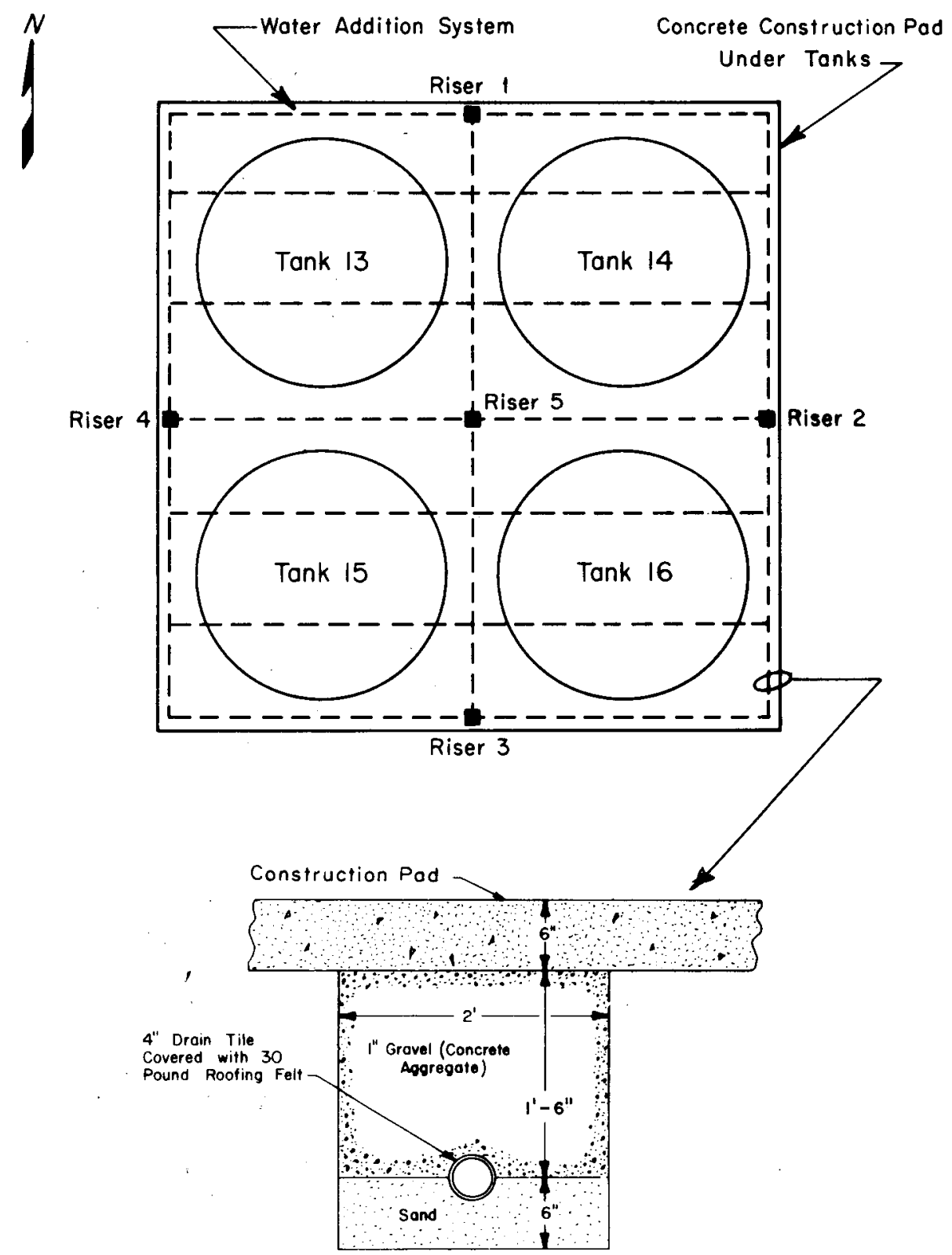

FIG. 2 WATER ADDITION SYSTEM 
The primary waste container or tank consists of two concentric steel cylinders assembled with a flat bottom and a flat top into a form somewhat like a doughnut. The top and bottom are joined to the outer cylinder by rings of curved knuckle plates. The inner cylinder, around the roof support column, is flared at the top to accommodate the capital of the roof support column.

All welds in the primary tanks were radiographically inspected. Any detected defects were corrected, and the welds were rechecked radiographically.

When construction of the bottom portion of the tank had been completed, the bottom was raised (as was done for the annulus pan) and all welds were assured to be adequate (by radiographic testing) and the pan was thoroughly cleaned. A layer of sand also contained by a "Sika-Igas" gasket was spread and screeded to a uniform depth of 1 inch; then the tank bottom was lowered into place, and the remainder of the tank was constructed.

The side walls of the reinforced concrete encasement are 33 inches thick and cast in two sections. The joint which connects the lower section of the side wall to the base $s$ lab is keyed for increased strength and contains a $24-0 z$ copper flashing water stop cast into the concrete. A schematic diagram of this joint can be seen in Figure 3 . The lower section of the side wall utilized the steel annulus pan as an inner form for the concrete. The side wall was poured to approximately the top of this pan. The top of this pour was scored to improve structural strength and bonding before the remainder of the side wall of the encasement was poured. (No metal water stop was provided.)

To facilitate inspection of the tank wall (after leaks were observed), eleven 8 -inch inspection ports were drilled through the concrete tank top into the annulus. The inspection ports are normally sealed with concrete plugs. These inspection ports plus the four original access ports provide capability for inspection of $\sim 73 \%$ of the side wall area of the primary tank.

The side walls and top of the concrete encasement were dampproofed with two layers of hot pitch. A cotton fabric was smoothly broomed on to the first layer while it was still hot. A coating of insulating material (i.e., "Cellotex"* or roofing paper) was applied to protect the second layer of pitch during backfilling with earth.

* U. S. Registered Trademark of National Chemical \& Plastics Co., Baltimore, MD 
The area surrounding the tanks was backfilled with soil removed from the lower section of the initial excavation and compacted to $98 \%$ of the maximum Proctor density.*

Dehumidification equipment consisting of a fan, a heater, and ductwork is installed on each tank to keep the annular space dry by circulating warm air at a temperature above its dew point. The ductwork shown in Figure 3 distributes the heated air around the bottom of the tank annulus. It contains 16 equally spaced slots with each opening $14^{\prime \prime} \times 6^{\prime \prime}$. The duct is constructed of sections of loosely fitting ducting. Several years after the initial waste leak into the annulus, a filter was installed on the annulus exhaust to prevent spread of radioactivity should any be entrained in the dehumidifying air. The dehumidification system has proved quite effective in promoting the self-sealing of the leaks by evaporating water from the waste and thereby causing salt deposits to form and seal the cracks.

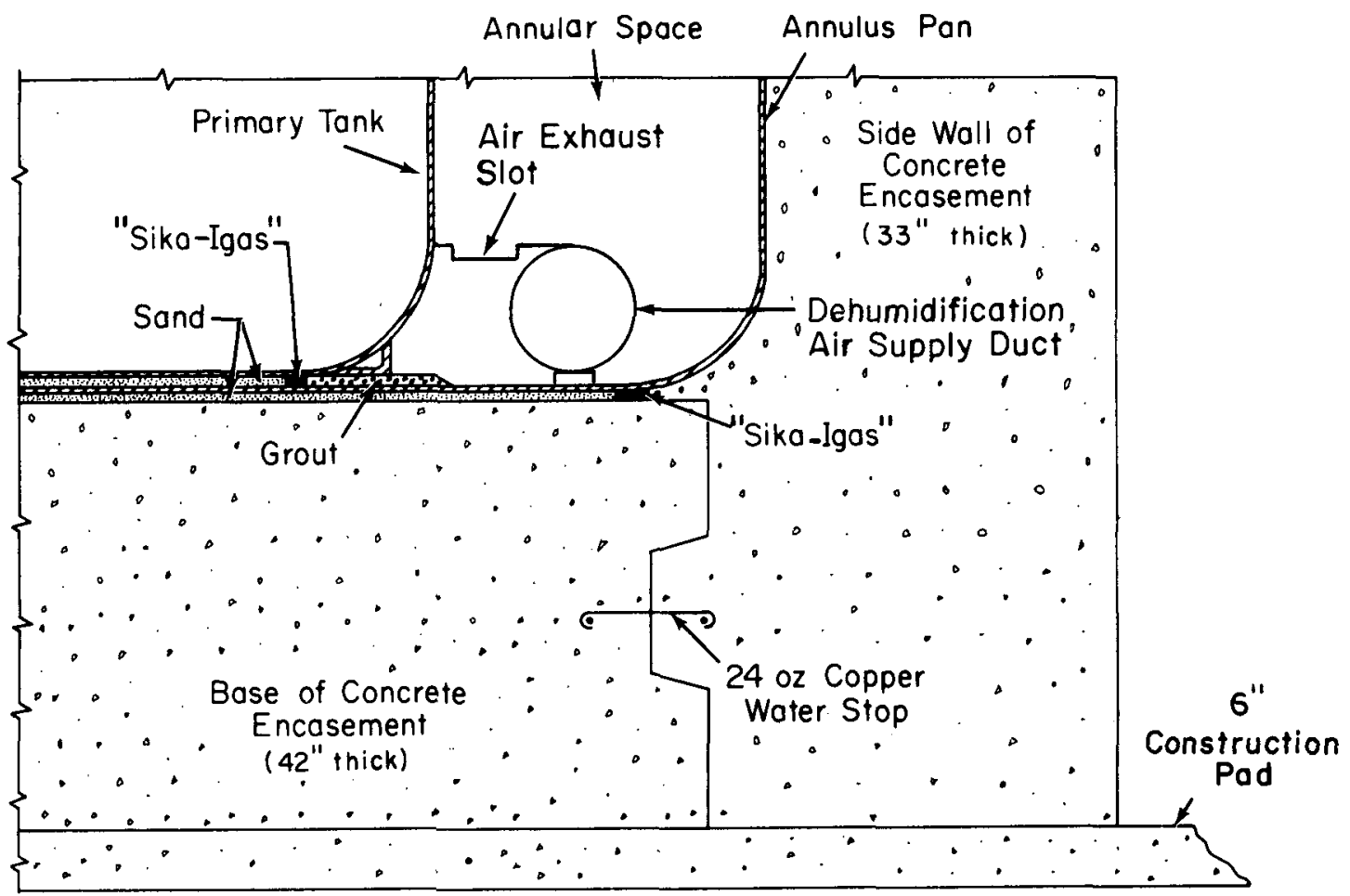

FIG. 3 DETAIL OF LOWER SECTION OF WASTE TANK

* Proctor density is a measure of the degree to which soil has been compacted. 


\section{TANK LEAKAGE}

Tank 16 was placed in service in May 1959 receiving HAW (high activity waste) from the $\mathrm{H}$-Area chemical separations process for the recovery of enriched uranium from SRP fuel elements. This alkaline waste contained principally sodium nitrate and sodium and aluminum hydroxides with some sulfates and carbonates. The following three sections describe the leakage of the primary containment barrier, the rationale for continued filling of the tank with a leaking primary containment barrier, and finally the overfill of the annulus pan (secondary containment) wiht the resulting leakage of radioactive waste into the soil, and monitoring efforts to locate the waste.

\section{INITIAL LEAKAGE OF PRIMARY VESSEL}

During October 1959, the Tank 16 annulus moisture alarm activated several times during periods of heavy rains. Annulus moisture alarms on Tank 13 and the empty Tank 15, and the sump alarm in Pump Pit 3 also indicated leakage, probably surface water, in these locations. Visual inspection of Tank 16 indicated that rainwater was leaking through the sealing compound used to seal the access port plugs. The Tank 16 annulus was inspected frequently, and was purged with heated air to dry the rainwater. In mid-November a small puddle of liquid was observed in the annulus under the north access port. A swab dipped into this liquid picked up radioactivity. No radioactive liquid was observed under the other three annulus access ports. White solid material was, however, observed protruding from the side of the tank beneath the south access port. While not the first known leak, it was the first observed leak location from any SRP primary waste container into the secondary containment annulus pan.

When the leakage was initially observed, the annulus dehumidification system was shut down to prevent spread of radioactivity to the atmosphere by the dehumidification air, which, at that time, was released directly to the atmosphere.

Within one week of the initial observation of waste under the north access port, contaminated liquid and white crystals were detected in the annulus pan under the south access port. The white crystals that had been observed during the previous week protruding from the side of the tank were found to be at the intersection of 
the lower knuckle plate and the vertical side wall of the tank. The crysta1s were in two groups separated by about a foot. These crystals were analyzed and shown to be crystallized waste.

Since this was the first time a leak point had been located, considerable effort was focused on inspection of the site in an attempt to establish the cause of the leak. As other leaks were discovered they were also examined. The cause of leakage was concluded to be stress corrosion cracking ${ }^{1}$ caused by the action of caustic or nitrate solutions on areas of high local stress in steel plates of the tank. The observed cracks are normally perpendicular to the tank welds and probably start at the inside surface. In al1, several hundred small cracks have been observed in Tank 16. More detail on the primary tank wall inspection can be found in Appendix D.

\section{RATIONALE FOR CONTINUED USE OF LEAKING TANKS}

The question of whether to continue to fill Tank 16 after observing leakage into the annulus was considered in November 1959 after the initial leak was discovered. Continued use was considered safe and prudent in view of the facts available at the time. The bases for this decision were:

- Experience with previously leaking tanks (Tanks 9, 10, and 14) during the previous two years indicated that the rate of leakage from waste tanks was slow $(<0.05 \mathrm{gal} / \mathrm{min})$ and intermittent. Generally, normal evaporation that takes place in the annulus had been sufficient to evaporate the liquid and plug the cracks with salt, thus preventing further leakage.

- The level of waste could be maintained within the steel annulus pan. If needed, a transfer jet could be installed in the annulus pan to transfer leakage to the primary container of another tank. A transfer jet installed on Tank 9, the tank with the largest previous leakage, was used to transfer the contents of the annulus back into the tank. This transfer capability was demonstrated during 1958 and 1959.

- The amount of storage capacity in $\mathrm{H}$ Area, at the time of the Tank 16 leakage, was limited to the unfilled volumes in Tanks 14 and 16 and that in the unused Tank 15. When the leak sites in Tank 16 were determined to be in the weld joining the lower knuckle plate to the side wall, an inspection and defect correction program was completed on Tank 15 before committing it to waste service.

Filling of the tank was completed in May 1960. 


\section{STEEL ANNULUS PAN OVERFILL}

The leak rate from the Tank 16 primary tank into the annulus pan was low between November 1959, when the leak was first discovered, and July 1960. Natural (not forced) ventilation of the annulus was sufficient to dry leakage and maintain an insignificant level in the annulus pan during the winter and spring months. With the coming of summer and higher humidity, leakage increased slightly in July and the liquid level in the pan reached $\sim 1$ inch by the first of August. (To eliminate release of possible contaminated air to the atmosphere, no forced dehumidification had been used since the leakage was discovered.) In an inspection of the annulus on the first of August it was observed that all of the salt deposits previously seen in the annulus and on the side of the tank had dissolved. The tank walls, dehumidifier duct, and annulus pan were dripping wet from condensed water vapor.

Due to the worsening conditions in the tank annulus, another attempt to dehumidify the tank annulus was initiated and the system was operated between August 12 and 21. Heated air was blown through the annulus and then to the tank before discharge to the environment through the tank reflux condenser and vent filter. This forced dehumidification was discontinued because contaminated air leaked from the annulus through defective seals on the annulus access port plugs. The radiation level of the forced air from the annulus to the tank had also increased significantly. The dehumidification was apparently successful since on the August 19 inspection, no condensation was observed. The liquid in the annulus, which had previously been clear, was turbid, probably due to crystallization of the waste salts.

The amount of waste in the annulus increased significantly between the August 19 and September 7 annulus inspections. The level in the annulus pan was rodded and found to be $4 \frac{1}{2}$ feet deep on September 7. Fabrication of a jet assembly for transferring the liquid from the annulus of Tank 16 to Tank 14 was undertaken immediately on an emergency basis.

Before the jet could be installed and the transfer started, the liquid level in the annulus reached the top of the steel annulus pan, and an estimated 700 gallons of waste exceeded this level for $a_{1}$ short time. Figure 4, a graph of the levels in the annulus during this period, shows the overfill. The estimate of 700 gallons is based on a straight line extrapolation of the measured level in the annulus to the time the waste transfer was started. Periodic operation of the annulus jet kept the level in the annulus below the top of the pan (Figure 5) after the initial annulus pan overfil1. The leak rate continued to increase until the liquid level in the tank decreased to the height of the horizontal weld between the top knuckle plate and side plate. The continuing 


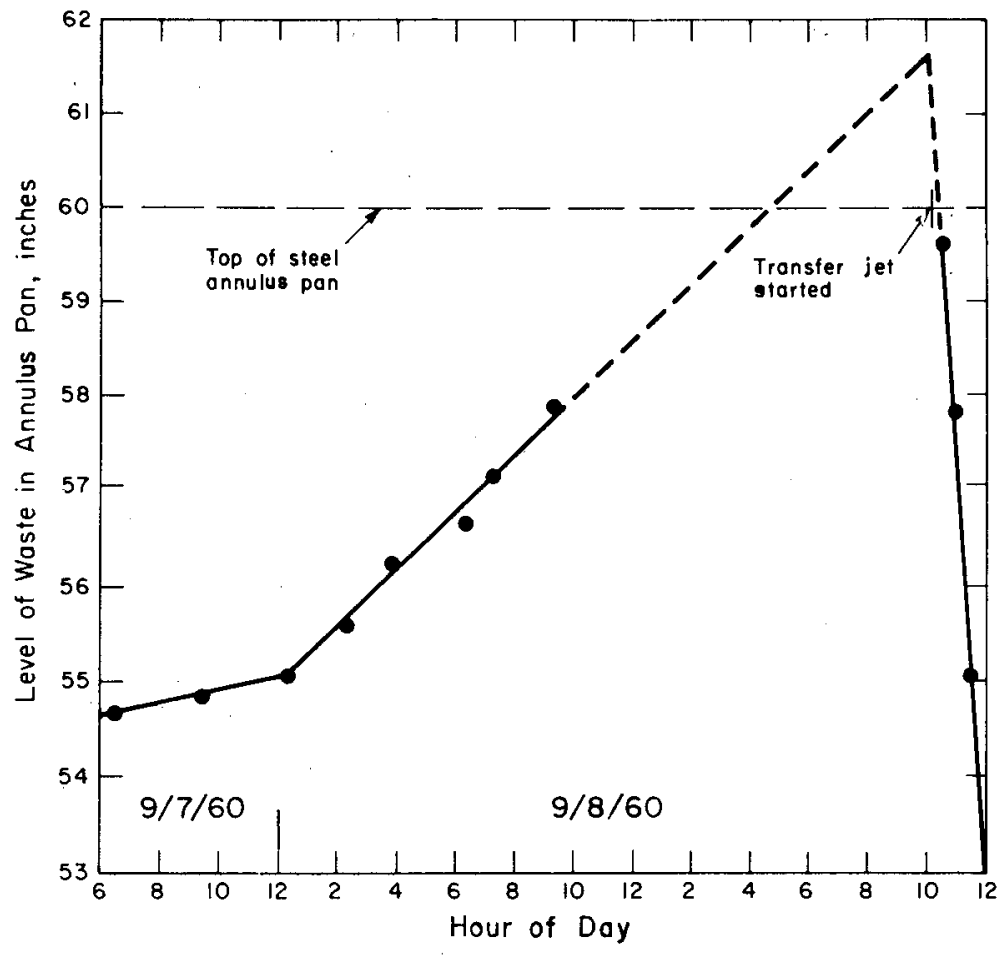

FIG. 4 WASTE LEVEL IN TANK 16 ANNULUS
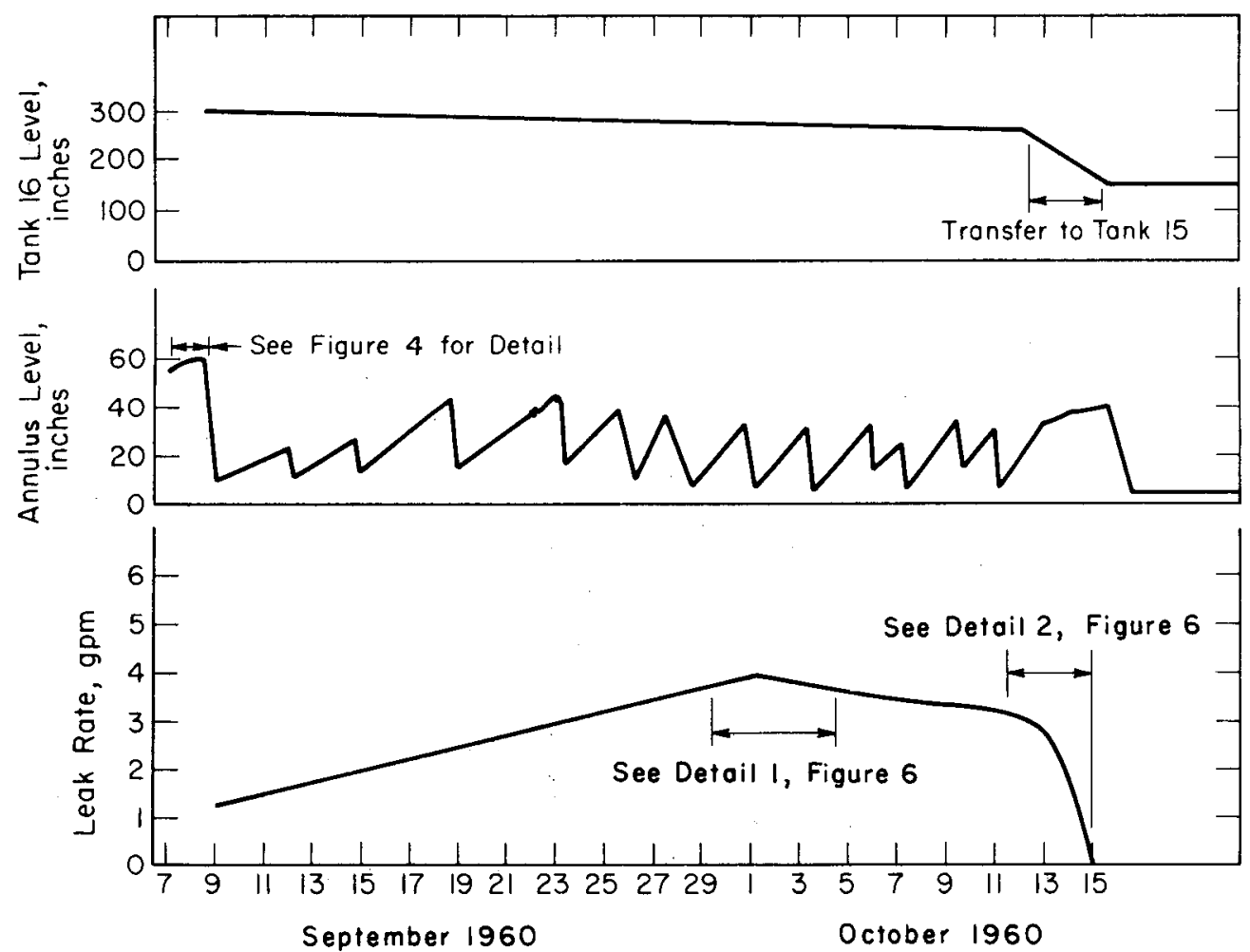

FIG. 5 WASTE TANK 16 LEAKAGE 
increase in the leak rate (Detail I of Figure 6) indicated that the size or number of the fault or faults on the upper knuckle plate weld continued to increase. When the waste inside the tank decreased to about the level of the upper knuckle plate weld, the leak rate decreased to $3.5 \mathrm{gpm}$ and leveled out at this rate. A total of about 185,000 gallons of waste leaked from the tank into the annulus pan and was transferred to Tank 14. The air supply duct, located at the bottom of the annulus, filled with waste; when the waste level was reduced, the waste leaked from the duct back into the annulus. As indicated earlier, the dehumidification system was not in use at this time.

A jet was installed to begin transferring part of the Tank 16 contents to Tank 15. Approximately 350,000 gallons was transferred by October 15. During the transfer from Tank 16 to Tank 15 the leak rate from Tank 16 into the annulus decreased stepwise. This pattern in the leak rate indicated three major areas of leakage existed below the upper knuckle plate weld. The areas were at about 223 in., 192 in., and 160 in. (Detail 2 of Figure 6).

Alkaline waste separates into two phases, sludge and supernate. The sludge phase, which settles to the bottom of the tank, is composed of a mixture of oxides and hydroxides of manganese, iron and some aluminum, and contains most of the fission products from the irradiated fuel. Cesium is the major fission product in the supernate. Samples taken of the supernate from Tank 16, given in Table 1 , indicate the waste had not completely separated into sludge and supernate as evidenced by the higher than expected radioactivity of $\mathrm{Sr}, \mathrm{Zr}-\mathrm{Nb}$, and $\mathrm{Ru}$. Samples of the waste in the tank annulus (Table 2) indicate that it was similar to the supernate in Tank 16 at the time, and contained 7.4 curies of radionuclides $\left(85 \%{ }^{137} \mathrm{Cs}\right)$ per gallon.

The estimated 700 gallons of waste that exceeded the level of the steel annulus pan represents an upper limit on the amount of waste that could have escaped from the tank into the ground. This amount of waste would contain 5,200 curies of radioisotopes. The actual amount of waste that reached the soil is not known, but for the waste to leak into the soil requires passage through a tortuous route and probably only a small fraction of the 700 gallons left the annulus. Possible routes that would lead to release are discussed in more detail in the section beginning on page 61 . 


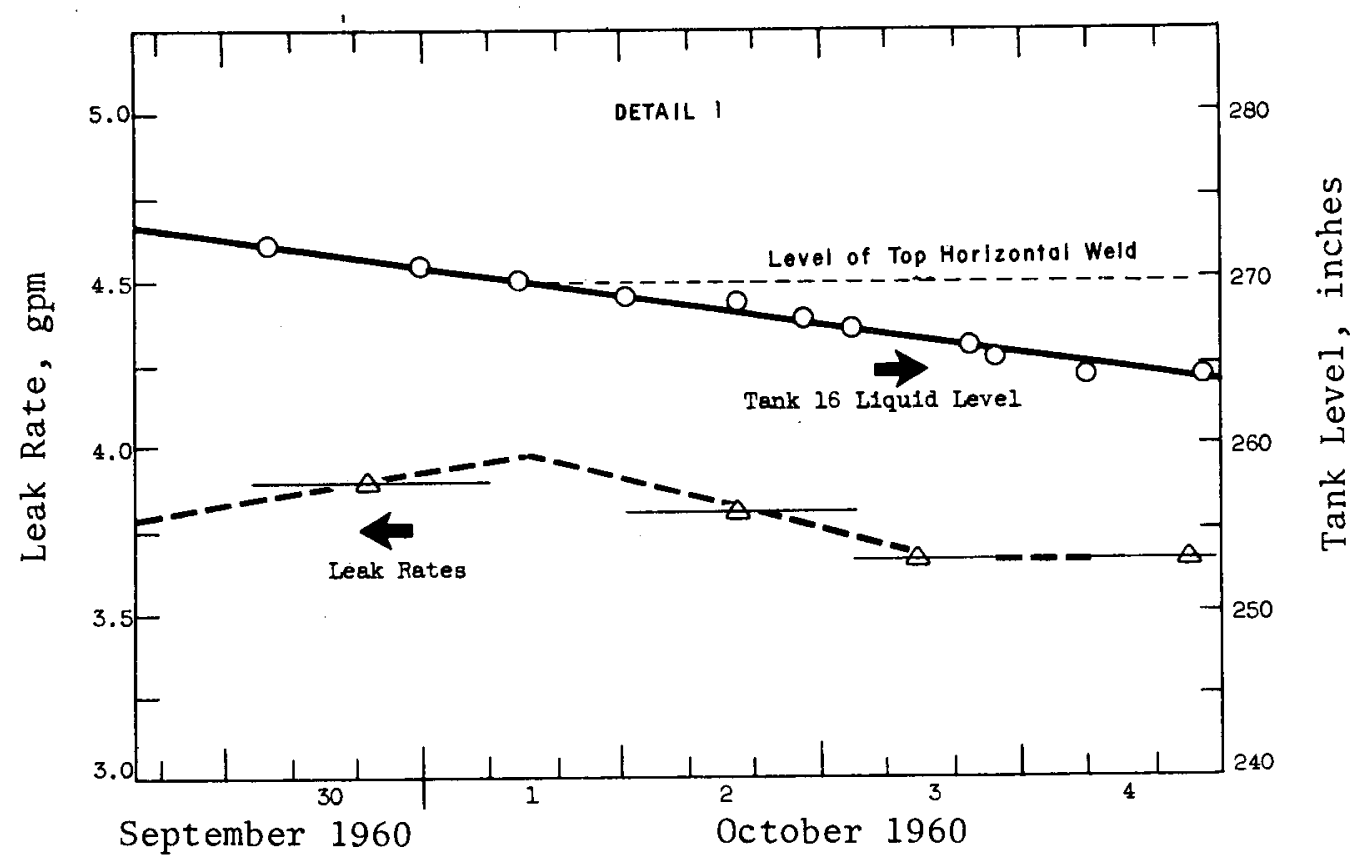

$\overline{8}$

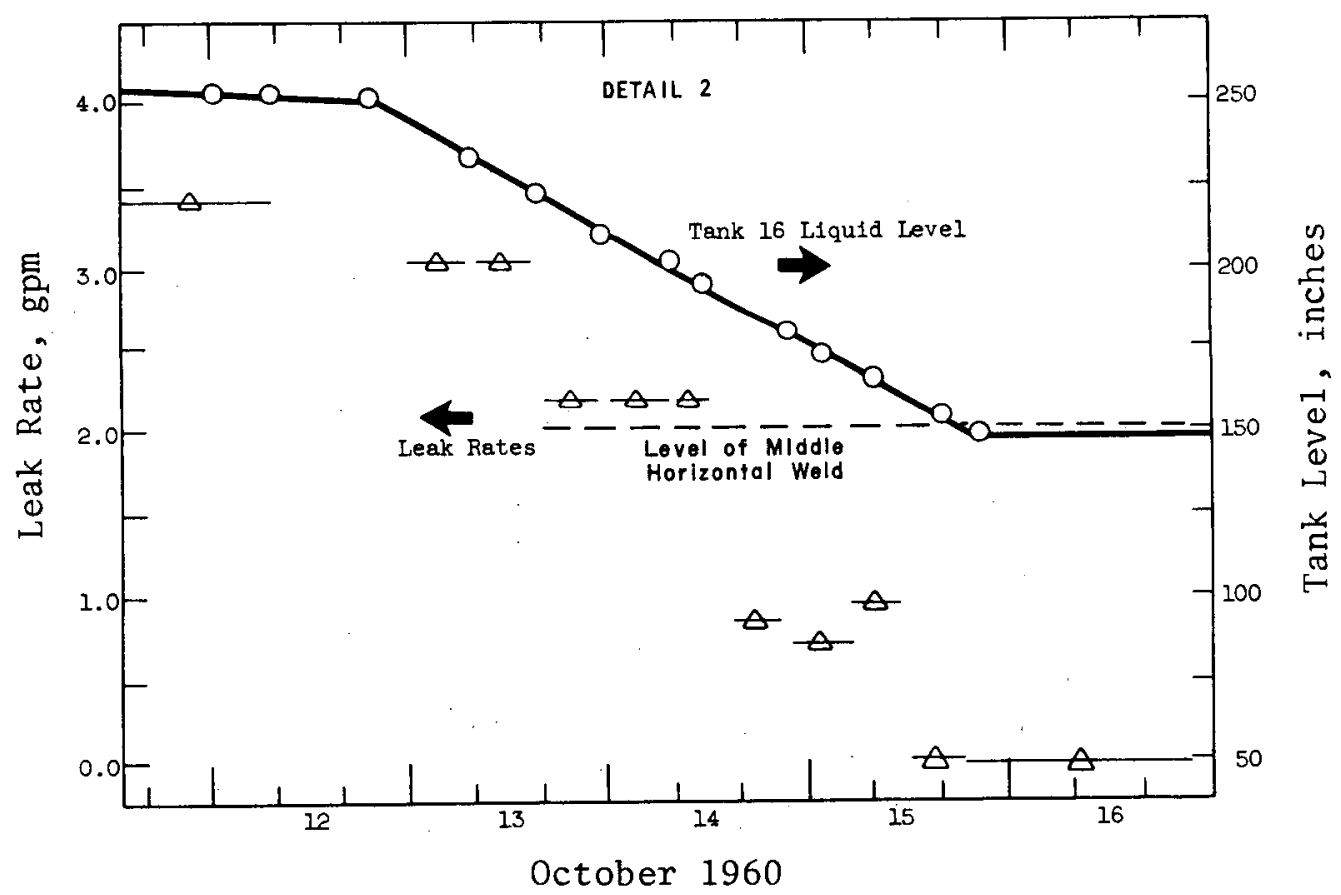

FIG. 6 WASTE TANK 16 LEAKAGE DETAILS 
TABLE 1

RADIOACTIVE CONSTITUENTS OF TANK 16 SUPERNATE

Concentration in

Concentration in Aged

Supernate from Tank 16

H-Area Supernate,

Constituent $\mu \mathrm{Ci} /$ gal

at Time of Leak, $\mu \mathrm{Ci} / \mathrm{gal}$

\section{${ }^{60} \mathrm{Co}$ \\ $141 \mathrm{Ce}$ \\ $154 \mathrm{Eu}$ \\ $243 \mathrm{Pu}$ \\ $237 \mathrm{~Np}$ \\ ${ }^{3} \mathrm{H}$}

$<3-12$

$<0.3-<35$

$30-3,600$

$<5-<10$

$<1-2$

$<2-4,900$

$1,500-6,800$

$100,000-170,000$

$1,000,000-15,000,000$

$<1-<44$

$<8<440$

$<3-5$

$0.01-240$

$<1-4$

$\sim 75$

$a$

\} 130,000

\} 540,000

\} 320,000

\} $6,400,000$

\} 3,200

12

$a$

4

0.03

a Not analyzed.

TABLE 2

ANALYSES OF WASTE FROM TANK 16

\begin{tabular}{lccc} 
& $\begin{array}{c}\text { From } \\
\text { Annulus }\end{array}$ & $\begin{array}{c}\text { Tank Supernatant } \\
\text { Solution }\end{array}$ \\
\cline { 2 - 2 } $\begin{array}{l}\text { Date of Sample } \\
\text { pH }\end{array}$ & $9 / 17 / 60$ & & $5 / 25 / 60$ \\
Specific Gravity & 11 & & $>11$ \\
Solid Content, wt $\%$ & 1.36 & 1.37 \\
$\mathrm{OH}^{-}, \mathrm{g} / 1$ & 42.0 & & 45.8 \\
$\mathrm{CO}_{3}=, \mathrm{g} / 1$ & $a$ & & 64.8 \\
$\mathrm{HCO}_{3}-, \mathrm{g} / 1$ & $a$ & & None detected \\
Gross Alpha, d/(min) (m1) & $5.2 \times 10^{3}$ & $7.6 \times 10^{3}$ \\
Gross Beta, c/(min) (m1) & $2.1 \times 10^{8}$ & $1.6 \times 10^{8}$ \\
Gross Gamma, c/(min) (m1) & $1.2 \times 10^{8}$ & $1.1 \times 10^{8}$
\end{tabular}

$a$ Not determined. 
Immediately following the overfill of the Tank 16 annulus pan a search was begun to determine how much radioactivity had leaked from the concrete encasement of the waste tank into the ground and also the radioactivity movement pattern. Monitoring wells were installed in the vicinity of Tank 16 as the initial phase of the assessment program. Sixty wells were installed above, below, and beyond the periphery of the concrete construction pad during the three months following the annulus pan overfill. These wells augmented detection capabilities of the four existing wells and the water addition system and provided the capability for monitoring radioactivity slightly above, immediately below, and 10-12 feet below the concrete construction pad. Four years after the annulus pan overfill, 17 soil samples were taken from the area surrounding Tank 16 to depths of 70-120 feet. (Appendix A describes a chrono1ogy of Tank 16 leakage and detection, and Appendix B presents results of the extended monitoring program.)

Radioactivity* has been found above and below the concrete construction pad in the vicinity of Tank 16 and at a distance of 15 feet from the edge of the concrete construction pad (35 feet from the outside surface of the waste tank). Samples taken 17002800 feet from the tank show no increased radioactivity. Only ${ }^{13{ }^{4}} \mathrm{Cs}$ and ${ }^{137} \mathrm{Cs}$ radioactivity has been detected adjacent to the tank or construction pad. (The other radioactive isotopes of the waste might have been masked by the cesium radioactivity.) The levels of radioactivity, except in 2 wells, have been significantly below the concentration guide (CG) level for cesium $\left(2 \times 10^{4} \mathrm{pCi} / 1\right)$ in drinking water given in Chapter 0524 of the AEC Manual. (The same value is used as the maximum permissible concentration in the Code of Federal Regulations-10 CFR 20.) The only ground water radioactivity exceeding CG limits was found in two well systems adjacent to the tank. These systems were pumped to accelerate water (and radioactivity) flow to the well system and the maximum activity reached $1.3 \times 10^{7} \mathrm{pCi} / 1$. Most of the radioactivity was detected in the water addition system (located immediately below the concrete construction pad and shown on Figure 2, page 17).

Samples of the ground water 15 feet from the concrete construction pad indicate very low levels of radioactivity to the northeast and to the south. The radioactivity is about $30 \mathrm{pCi} / 1$ (several times background) in the area east of the tank. One well to the northeast of the tank reached about $1400 \mathrm{pCi} / 1$ (apparently due to more rapid movement through an area of higher permeability) by 1965, when it became necessary to abandon sampling the well due to pluggage. Radioactivity up to about $50 \mathrm{pCi} / 1$ was observed to the

*Non-volatile beta analysis was used to determine the radioactivity of ground water unless otherwise noted. This general purpose analysis measures both beta and gamma radioactivities of the samples. Calibration for this analysis was established using Radium D \& E standards. 
south of the tank. Radioactivity to the north of the concrete construction pad is essentially at background (5-15 pCi/1). It should be noted that the wells to the north of the tank are also about 100 feet farther from Tank 16 than those to the south and east (but not from the water addition system, which was known to contain radioactivity). The radioactivity to the west of Tank 16 exhibited a short initial increase, but has since returned essentially to background.

Figure 7 shows the location of radioactivity found above the concrete construction pad. This figure shows the location of the wells and indicates the areas examined, and shows where ground water radioactivity was found immediately after the leak. We1ls from which contaminated soil and water-proofing mastic were removed are also listed. All other soil samples from these wells were at background radioactivity levels. Most of these we11s were installed and used only for a limited period of time and then backfilled. Wells 5, 7, and 8 have been used for long-term monitoring. Figure 8 , which gives the ground water radioactivity from these wells from January 1961 to the present, shows the effect of the mixing of radioactivity and ground water caused by pumping ground water from the water addition system in 1961 and 1962, then the slow decrease as the system came to equilibrium, followed by the slow increase in radioactivity probably caused by dispersion as the radioactivity moved through this soil. Figure 9 shows the radioactivity of the water pumped from Well 6. As can be seen, the concentration of radioactivity decreased after pumping from the water addition system was started, indicating some connection (probably through cracks in the concrete construction pad) between Well 6 above the construction pad and the water addition system below the pad.

A pump was installed in the water addition system (Figure 2, page 17) and used intermittently to remove water at 11.4 iters $/ \mathrm{min}$ from December 1960 through August 1962 and again from August through mid-November 1973. The radioactivity removed during the above times is shown on Figure 10. As Figure 10 indicates, water was pumped from two of the five risers, but since the entire system is one well field, the riser or risers are unimportant. What is important, however, is that the contaminated water was returned to the water addition system during December 1960 and January 1961 (top part of Figure 10) and continuously removed thereafter. The radioactivity found initially in the water addition system was 1.2 curies (based on average water analysis of $9 \mu \mathrm{Ci} / 1$ ). This decreased to 0.5 curies before activity removal began, probably due to ion exchange with the soil at the interface of the water addition system. A total of 5.6 curies of radioactivity was removed from this system over the next few years. The 5.6 curies of radioactivity removed compared to the 1.2 curies initially found indicates the pumping of the system caused radioactivity to move to the system from the ground. 


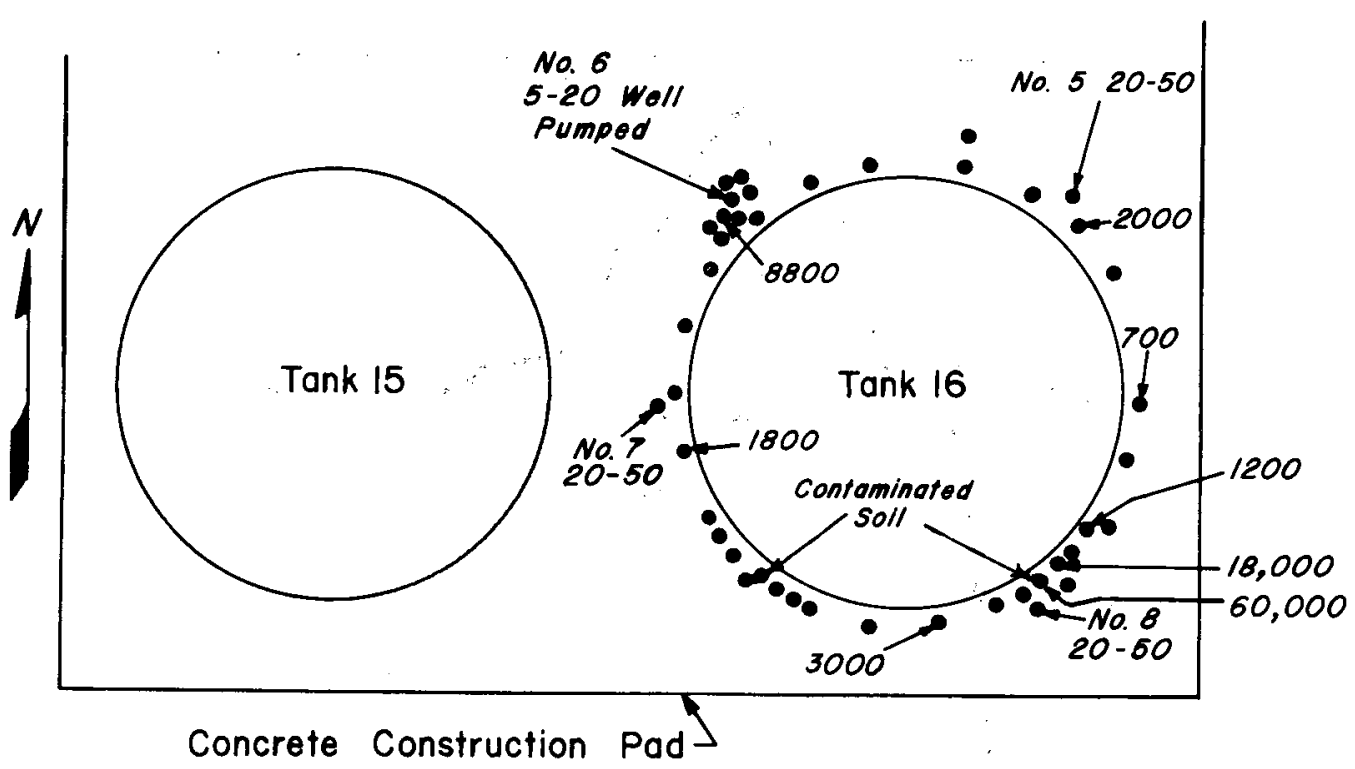

Radioactivities in $\mathrm{pCi} / \mathrm{I}$

Wells with no indication of rodioactivity were of background $(5-15 \mathrm{pCi} / 1)$

See Figure 8 for Long-Term Monitoring of Wells 5, 7, 8, and Figure 9 for Well 6

FIG. 7 RADIOACTIVITY LOCATED ABOVE CONSTRUCTION PAD

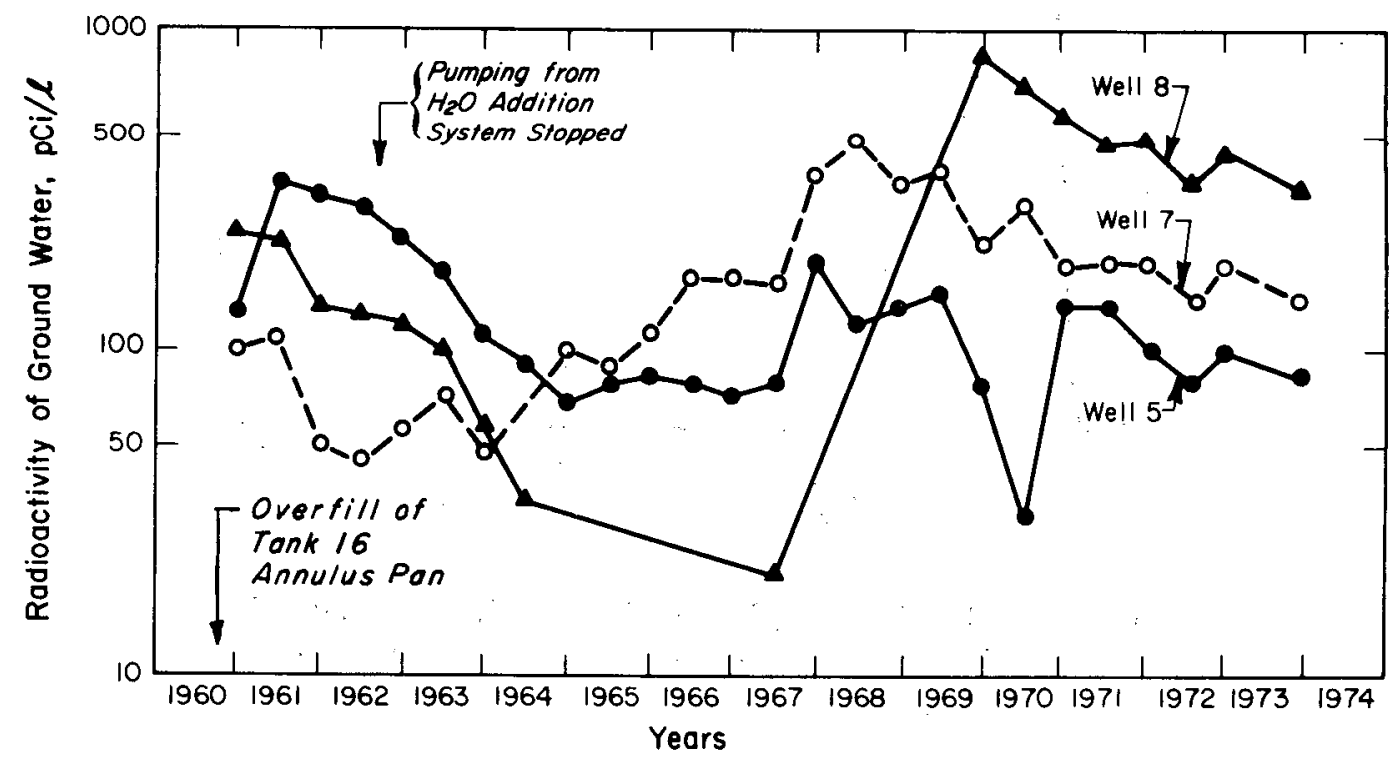

FIG. 8 RADIOACTIVITY OF GROUND WATER ABOVE CONSTRUCTION PAD 


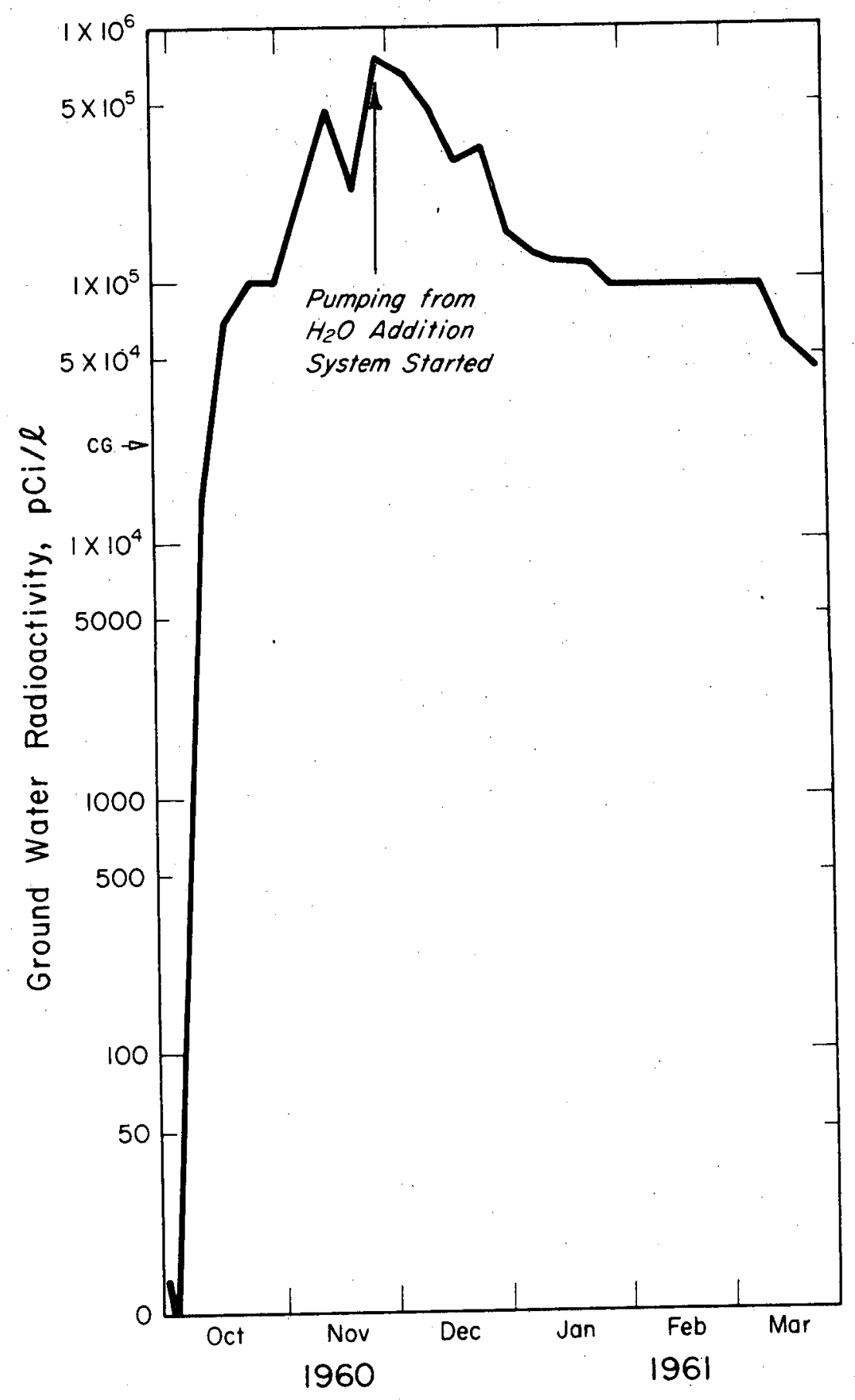

FIG. 9 RADIOACTIVITY OF GROUND WATER PUMPED FROM WELL 6 ABOVE CONSTRUCTION PAD 


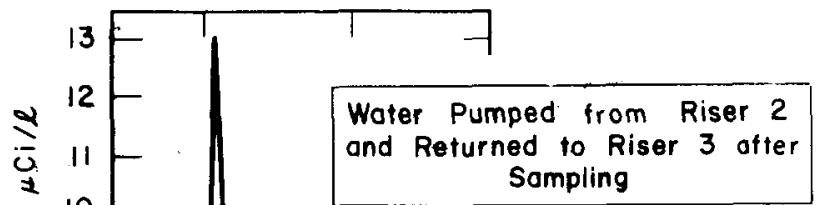

2: Radioactivity Removed

by Vermiculite Ion

Water Pumped from Riser 5: Radioactivity Removed by Exchange Column Vermiculite lon Exchange Column

Woler Pumped from Woter Addition System Not Returned

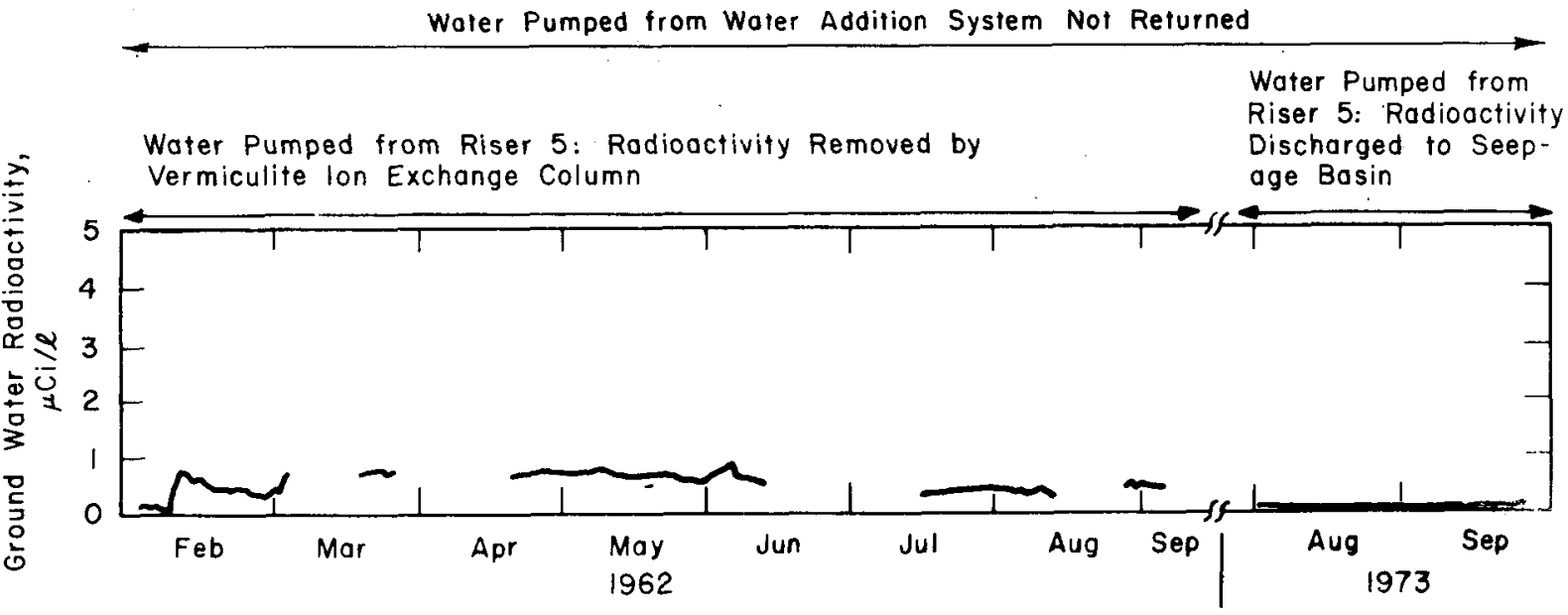

FIG. 10 RADIOACTIVITY REMOVED FROM WATER ADDITION SYSTEM 
Figure 11 shows the location of wells 10 to 12 feet below the concrete construction pad. The gray areas bounding these wells show the radioactivity of the ground water from these wells. Concentrations are given at two different times: within 1-3 months after the annulus pan overfill and at a later date (normally after 1963 , 3 years after the overfi11). Concentrations have been reasonably constant since 1963 except in Wells 2 and 3 (see Figure 12). Samples taken from We11 2, located near the center of the construction pad showed water radioactivity only slightly above background for the first several months after the overfill. A significant increase was observed about 9-10 months after the overfill, and the radioactivity approached that of the water radioactivity in the water addition system. This radioactivity reached a peak in Spetember-November 1961 (about 14 months after the overfil1) and has since decreased. The concentration of cesium in Wel1 2 was probably influenced by the radioactivity of the water addition system. Well 3 radioactivity to the east of the tank area steadily increased, reaching $\sim 1400 \mathrm{pCi} / 1$ in 1966 when sampling was abandoned due to pluggage of this small (1-in. diameter) well.

The wells represented by the triangular symbols on Figure 11 were installed about four years after the overfill to provide soil samples to depths of 70-120 feet below the concrete construction pad. Soil from only three of these wells contained radioactivity above background with the other wells at or near background. In the three wells containing radioactivity, the maximum radioactivity was just below the concrete construction pad, and the radioactivity decreased to background within 20 feet.

Pumping the ground water from an area of leakage is one means of preventing leachable radionuclides in the ground water from moving from the site of a leak. It also allows slow removal of the leaked radionuclides. If this technique is to be successful, the pumping rate must be sufficient to create a depression in the water table adequate to cause all water containing the radionuclides to flow toward the pump. This technique was demonstrated at Tank 16 by pumping only $4 \mathrm{gpm}$ of ground water from the water addition system (located under Tanks 13, 14, 15, and 16). Appendix F describes this demonstration. In view of the low concentration of radioactivity in the ground water pumped from this system, its use was discontinued in 1962 . 


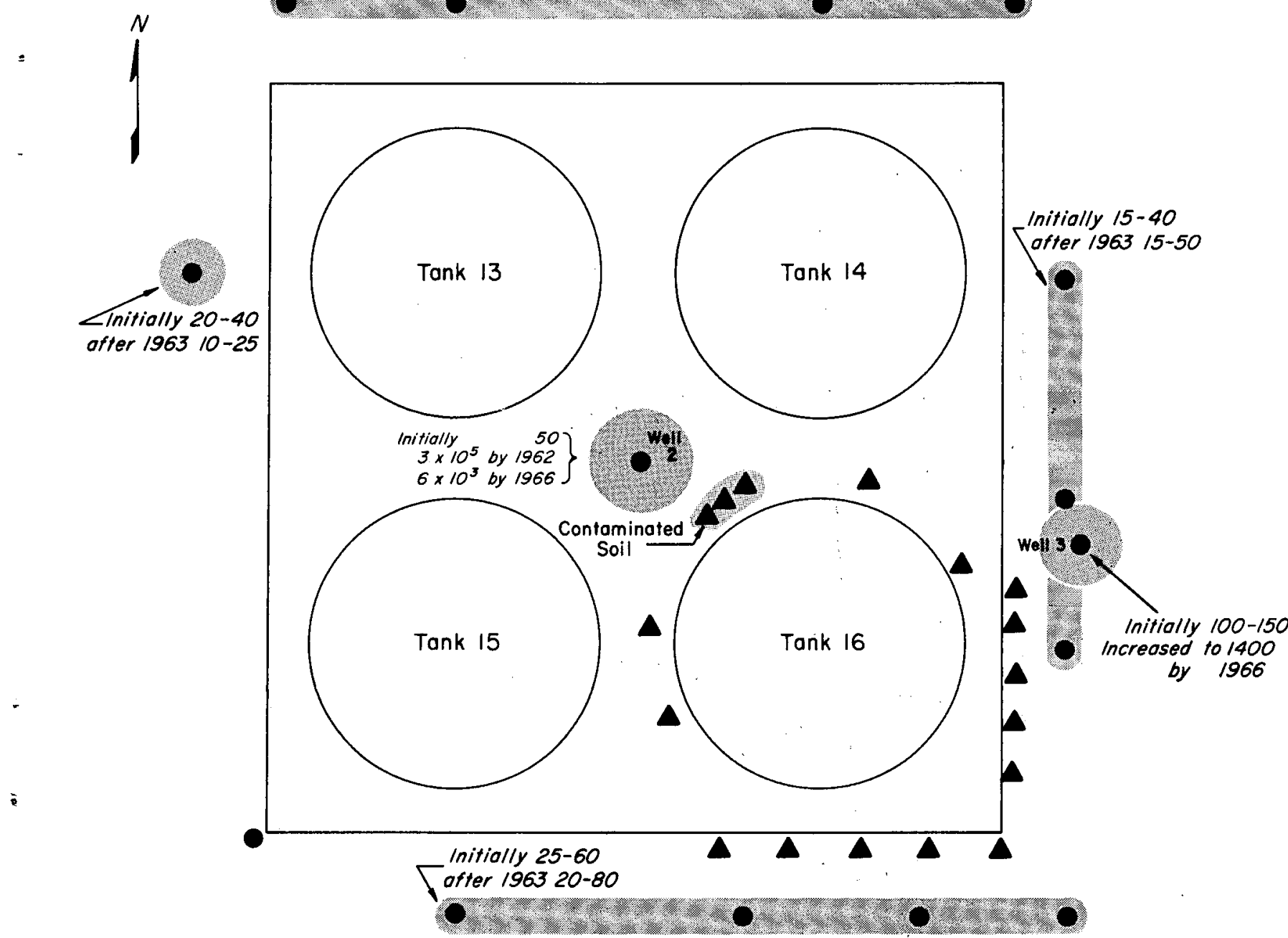

Legend:

- Ground Water Somple Points $10-12^{\prime}$ below Pad

- Soil Core Samples" to 70-120' below Pad

Radioactivities in ocill.

Soil Radioactivity Found in Ist $20^{\prime}$ below Fad (Ranged $15-180 \mathrm{pCi} / \mathrm{g}$ ) Other Core Samples at Bockground.

FIG. 11 RADIOACTIVITY OF GROUND WATER BELOW CONSTRUCTION PAD 


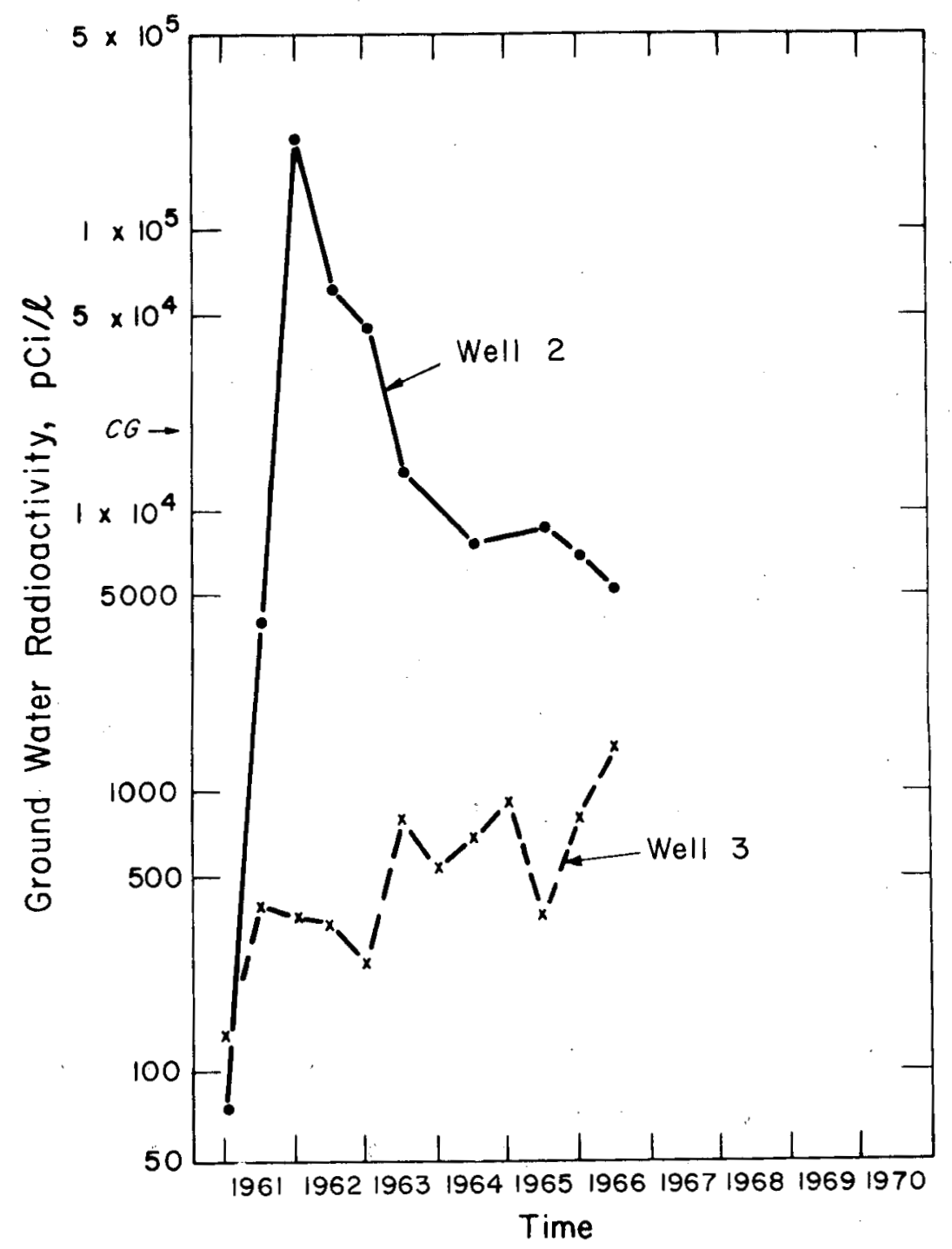

FIG. 12 GROUND WATER RADIOACTIVITY BELOW CONSTRUCTION PAD

\section{INLEAKAGE OF WASTE INTO ANNULAR SPACE}

During a periodic inspection of waste tanks in February 1972, streaks of white solids were observed on the wall of the annulus pan of Tank 16 at several locations. Figure 13 is a photograph of some of these streaks. They appear to have formed from the drying of solids-bearing liquids that ran down from the top of the annulus pan. White solids were also observed on top of and hanging from the ledge formed by the stiffening ring at the top of the pan. Samples were taken of the material on the ledge, hanging from the edge of the ledge, and also from the top of the salt bed at the bottom of the annulus. Attempts to scrape a sample of the streaks on the pan were hampered by the intervening ledge and poor visibility so no sample was obtained. 


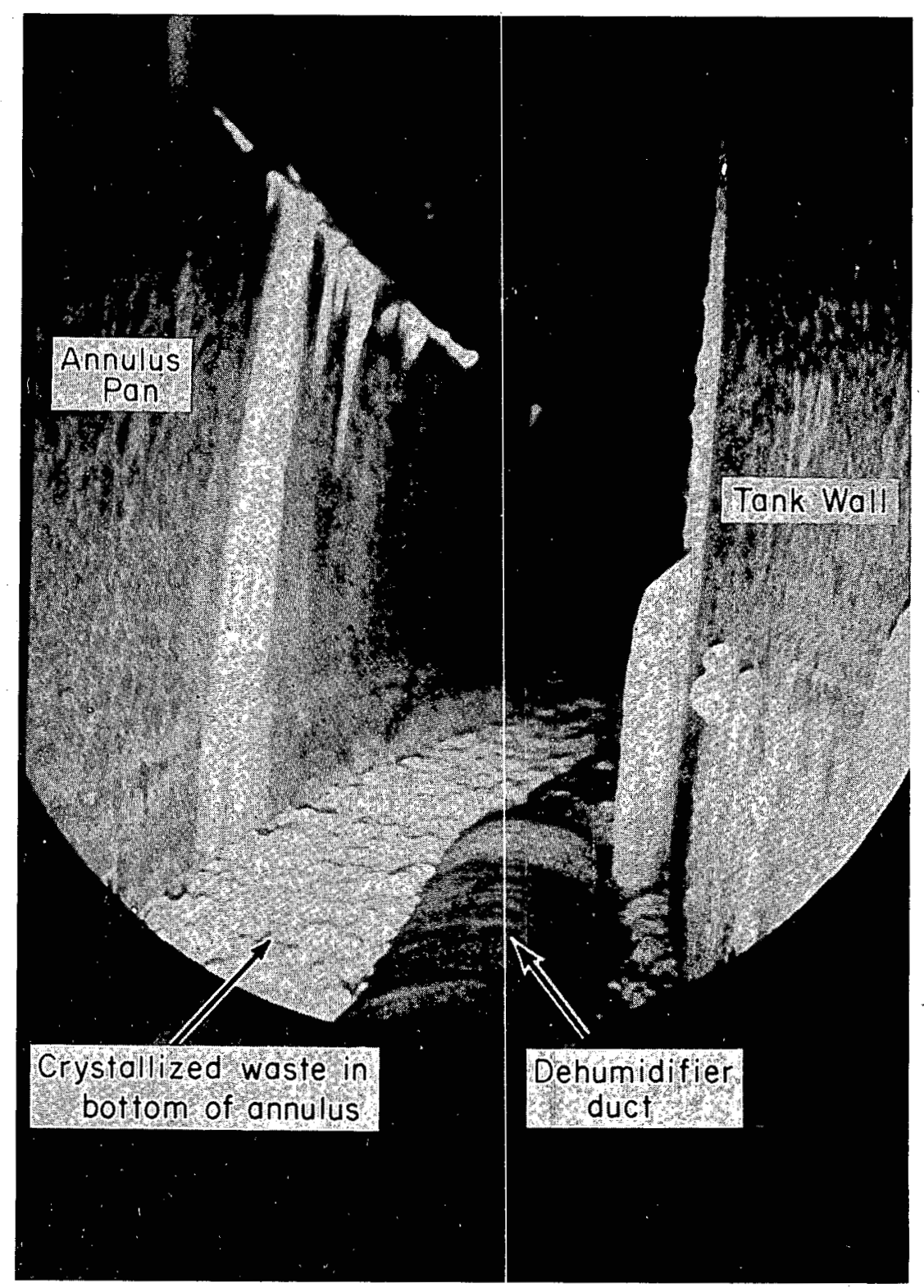

FIG. 13 WASTE TANK 16 ANNULUS INSPECTION February 10, 1972

Analyses (Table 3) show that the samples are all highly radioactive and largely water-soluble. The ${ }^{137} \mathrm{Cs} /{ }^{134} \mathrm{Cs}$ ratio indicates that the ledge material was about the same age as the waste that leaked out of the tank in September 1960. The sample of the top layer of salt from the pan was about 10 years younger and indicates 
continued leakage of new waste from the tank into the annulus. Neithe the salt streaks on the pan wall nor the salt on the pan ledge were visible in color photographs taken through the periscope in the annulus following the overfill of the annulus pan. Thorough examinations were made in 1961 and 1962, and therefore it can be assumed that they formed since that time. Two hypotheses could explain the pan-wall salt; both assume that some part of the waste that overfilled the pan in 1960 was retained in the space outside the pan but still within the concrete encasement.

- Increased hydraulic loading as the tank was refilled may have decreased the volume between the pan and concrete encasement, forcing some of the waste diluted with ground water back into the annulus.

- Waste between the pan and the concrete slab (or, conceivably, even in the earth surrounding the tank) may be carried or displaced into the annulus by slow inleakage of ground water. Appendix E shows that the ground water elevation near Tank 16 was above the pan top for a considerable time during the interim.

TABLE 3

SAMPLES FROM TANK 16 ANNULUS

February 1972

\begin{tabular}{|c|c|c|c|}
\hline & Top of Salt Bed & $\begin{array}{c}\text { Edge } \\
\text { of Pan Ledge } \\
\end{array}$ & $\begin{array}{l}\text { Top } \\
\text { of Pan Ledge }\end{array}$ \\
\hline Description of Sample & $\begin{array}{l}\text { Wet, Iight } \\
\text { brown, sandy } \\
\text { appearance }\end{array}$ & $\begin{array}{l}\text { Dry solid, } \\
\text { white to } \\
\text { brown, } \\
\text { oatmeal } \\
\text { appearance }\end{array}$ & $\begin{array}{l}\text { Dry solid, white } \\
\text { and brown, oat- } \\
\text { meal appearance }\end{array}$ \\
\hline $\begin{array}{l}\text { Solubility in } \mathrm{H}_{2} \mathrm{O} \text {, wt } \% \\
\text { Relative sample radiation } \\
\text { compared to top of pan } \\
\text { ledge sample }\end{array}$ & 82 & 99 & 99 \\
\hline $\begin{array}{l}\text { mrads } \\
\mathrm{mR}\end{array}$ & $\begin{array}{l}20 \\
20\end{array}$ & $\begin{array}{l}2.7 \\
3\end{array}$ & $\begin{array}{l}1 \\
1\end{array}$ \\
\hline \multicolumn{4}{|l|}{ Radioactivity, d/(min) (g) } \\
\hline $\begin{array}{l}137 \mathrm{Cs} \\
134 \mathrm{Cs}\end{array}$ & $\begin{array}{l}1.5 \times 10^{9} \\
2.5 \times 10^{8}\end{array}$ & $\begin{array}{l}8.3 \times 10^{8} \\
5.5 \times 10^{6}\end{array}$ & $\begin{array}{l}4.5 \times 10^{8} \\
3.7 \times 10^{6}\end{array}$ \\
\hline${ }^{137} \mathrm{Cs} /{ }^{134} \mathrm{Cs}$ ratio & 6 & 151 & 122 \\
\hline $\begin{array}{l}\text { Age, years (assume } x \text { years } \\
\text { at i } 3^{7} \mathrm{Cs} /{ }^{13}{ }^{4} \mathrm{Cs} \text { ratio of } 6 \text { ) }\end{array}$ & $\mathrm{x}$ & $x+10.6$ & $x+9.9$ \\
\hline
\end{tabular}




\section{FATE OF LEAKED HIGH ACTIVITY WASTE IN SRP SOILS}

The following four sections describe 1) the location of the waste tank farm containing Tank 16 and how radioactivity that leaked into the ground would reach the public, 2) typical waste composition, 3) description of radionuclide movement through SRP soil, and 4) impact of the Tank 16 leak.

\section{HYDROLOGY OF THE WASTE TANK FARMS}

The Savannah River Plant is located in the Atlantic Coastal Plain about 25 miles from it western edge. Most of the plant surface consists of a plateau (Aiken plateau) dissected by five tributaries of the Savannah River. The H-Area Waste Tank Farm, containing Tank 16, is on the plateau in an interstream area between Upper Three Runs on the north and Four Mile Creek to the south. Upper Three Runs rises off the plantsite and is a large stream. Four Mile Creek rises a few miles above the tank farm and is smal1 by comparison. Consequently, Upper Three Runs is more deeply incised than Four Mile Creek. The bed of Upper Three Runs is about 160 feet below the plateau elevation, while Four Mile Creek is only 100 feet below the plateau elevation.

Figure 14 shows the surface distribution of geologic formations; the Congaree is included with the McBean because both are of Claiborne age. The Tuscaloosa crops out in the Savannah River valley a few miles upstream from the plant, but not on the plantsite.

The near-surface sediments of the area near the waste tank farm consist of nearly a thousand feet of mostly unconsolidated sands, clayey sands, sandy clays, and clays overlying the basement metamorphic crystalline rock. Figure 15 shows the southeastward dip and thickening wedge of these Coastal Plain formations. One zone in the unconsolidated sediments contains lime and shells. This calcareous zone is in the lower section of the McBean formation and crops out at Upper Three Runs, but is well below the bed of Four Mile Creek. The McBean and Tuscaloosa formations contain the principal aquifers for the areas surrounding the Savannah River Plant. All formations in the tank farm interstream area contain ground water. Figure 16 shows the vertical distribution of hydrostatic head in ground water near the H-Area Waste Tank Farm measured in eleven piezometers.

$\mathrm{H}$ Area is on a topographic divide between Upper Three Runs and Four Mile Creek, where meteoric water (rain, snow) enters the ground and is drained into valley streams. In general, shallow ground water 


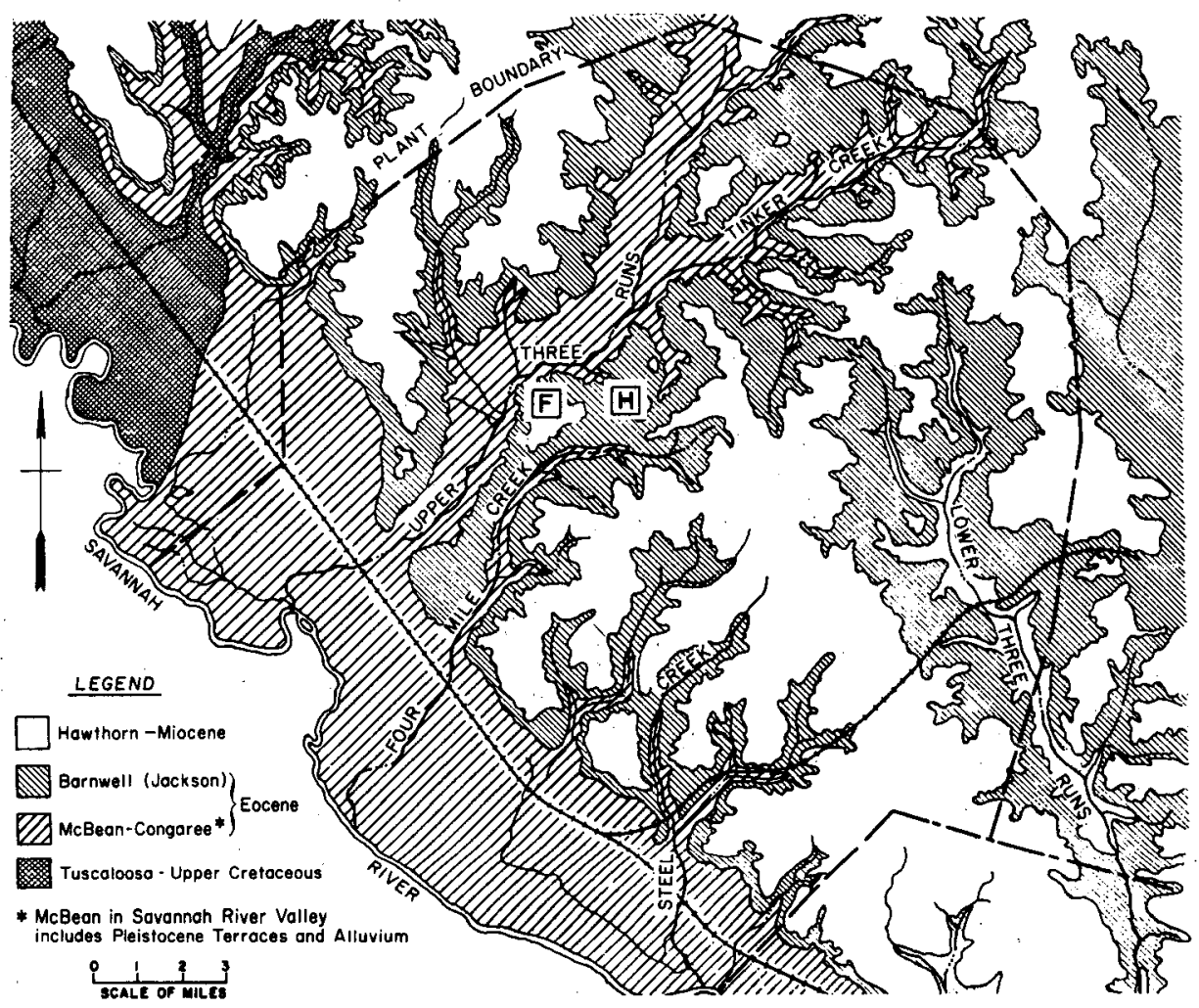

FIG. 14 SURFACE FORMATIONS AND DRAINAGE AT THE SAVANNAH RIVER PLANT

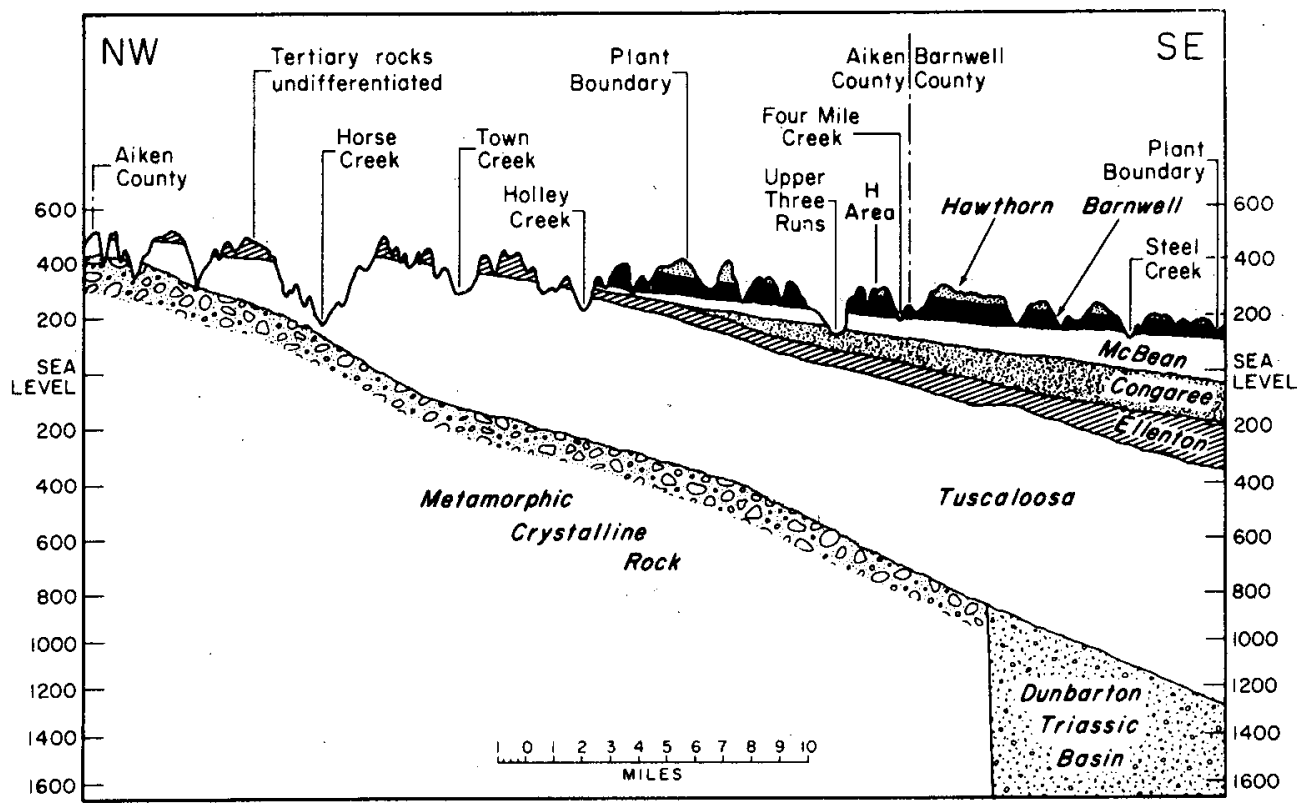

FIG. 15 GENERALIZED NW TO SE GEOLOGIC PROFILE ACROSS THE SAVANNAH RIVER PLANT 


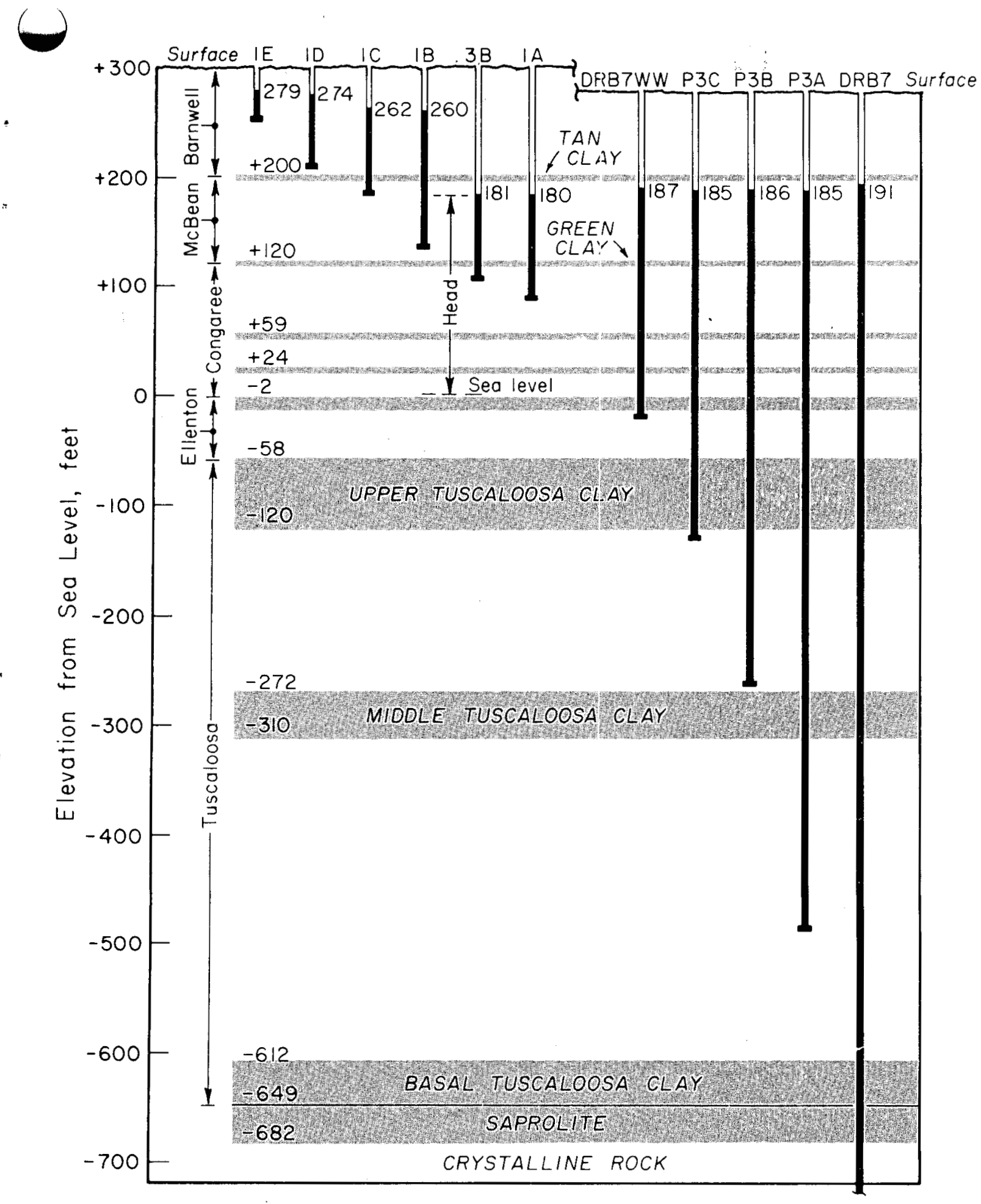

FIG. 16 HYDROSTATIC HEAD IN GROUND WATER NEAR H AREA 
is drained by local streams, and deeper ground water is drained by more-distant streams. Downward percolation of water from the water table is indicated by decline to minimum head in the Congaree formation. In the two piezometers in the Barnwell formation above the tan clay (1E and 1D, Figure 16), the decline is probably fairly uniform with depth. Across the tan clay (1D to 1C), the decline is relatively abrupt (12 ft of decline in about $18 \mathrm{ft}$ of depth). The tan clay is about $12 \mathrm{ft}$ thick and is sufficiently impermeable to divert much of the water laterally to creeks. The nearest creek is several thousand feet away.

Within the fairly permeable sands of the McBean formation, the head declines only $2 \mathrm{ft}$ in $\sim 50 \mathrm{ft}$ of geologic material (1C to $1 \mathrm{~B}$ ). The green clay at the base of the McBean formation (shown on Figure 16) is one of the more-significant hydrologic units in the region; it is only 6 to $10 \mathrm{ft}$ thick under H Area (although somewhat thicker elsewhere), and its importance is easily missed if only drilling information is available. The $80-\mathrm{ft}$ decline in piezometric head ( $1 \mathrm{~B}$ to $3 \mathrm{~B}$ and $1 \mathrm{~A}$ ) across the green clay indicates that the clay is continuous over a large area and is quite impermeable. Thus the green clay also diverts water laterally to creeks that have eroded down into the McBean. These points of discharge are farther from $H$ Area than the discharges from the Barnwell formation.

Ground water in the Congaree zone below the green clay also discharges into Upper Three Runs. This formation has the lowest hydrostatic head. The Ellenton formation has a head $\sim 7 \mathrm{ft}$ higher. than the Congaree, thus indicating the Ellenton is not receiving water from the Congaree formation.

Head is uniform in the three Tuscaloosa piezometers (P3C, P3B, P 3A), lower than that in the Ellenton formation (DRB7WW), but higher than those in the Congaree. These Tuscaloosa piezometers are within the influence of the cone of depression caused by pumping water-supply wells in $\mathrm{H}$ Area, and to a lesser extent in F Area. The condition that their head's are about equal may be imposed by the pumping. The natural water level would be higher than the present water level, and some data indicate that the natural level is $2192 \mathrm{ft}$. Both the recharge and discharge regions of the Tuscaloosa are principally off the plantsite, and they control its water level within the plantsite. 
Piezometric contours for the Tuscaloosa formation (Figure 17) indicate that the Tuscaloosa water flows from the Aiken plateau in a curved path to the Savannah River valley. This lateral flow through the very permeable formation supports the Tuscaloosa water level on the plantsite. Recharge by vertical percolation from above is unimportant.

Any contamination entering ground water from $\mathrm{H}$ Area would be transported both downward and laterally, especially laterally at each clay barrier. Because water heads in the Tuscaloosa and Ellenton formations are higher than in the Congaree, such contamination would be discharged into Upper Three Runs before it could enter the Tuscaloosa.

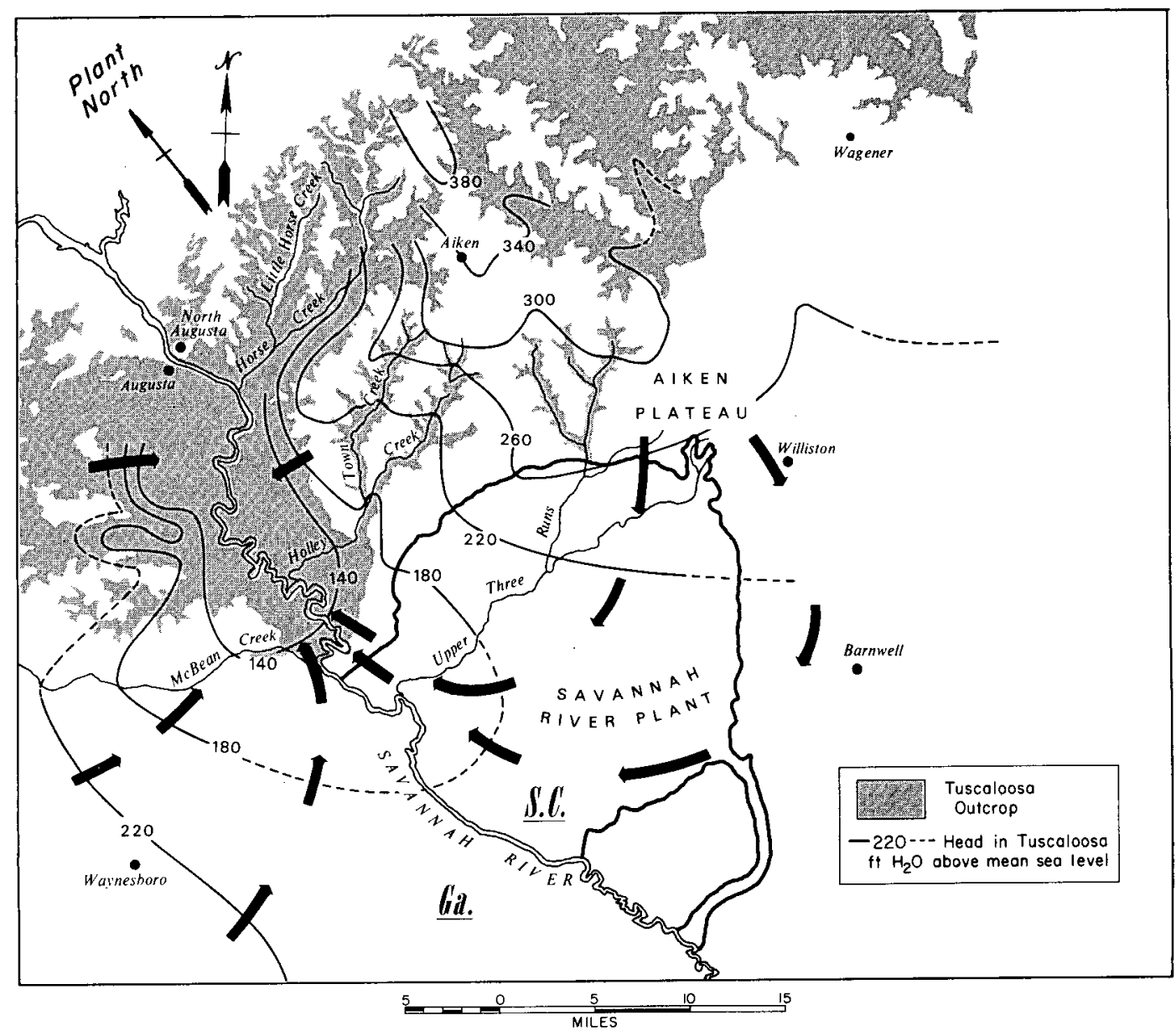

FIG. 17 FLOW IN TUSCALOOSA AQUIFER 
The flow path of ground water in the Hawthorn and Barnwell formations from H-Area waste tanks to the creek is not well defined because of the proximity to the water table divide where the gradients are very low. The slope is 0.2 to $0.7 \%$ near the tanks and increases to $10 \%$ near the outcrop along Upper Three Runs. Because of the very flat water table, several flow paths are possible. Fenimore ${ }^{5}$ concluded that the most likely path is shown by the solid lines of Figure 18 and is about 9000 feet long. The normal flow path was obtained from numerous ground water table contour maps (some drawn at 2-foot contours). Fi.gure 18 is given at 20-foot contours and shows the water table divide. Two shorter flow paths are possible and thus must be considered. One such flow path follows the dashed line on Figure 18 leading to a tributary of Upper Three Runs which is only 2500 feet north and east from Tank 16. Another possible flow path would lead to the tributary of Upper Three Runs which rises west of H-Area. This flow path would also be 22500 feet.

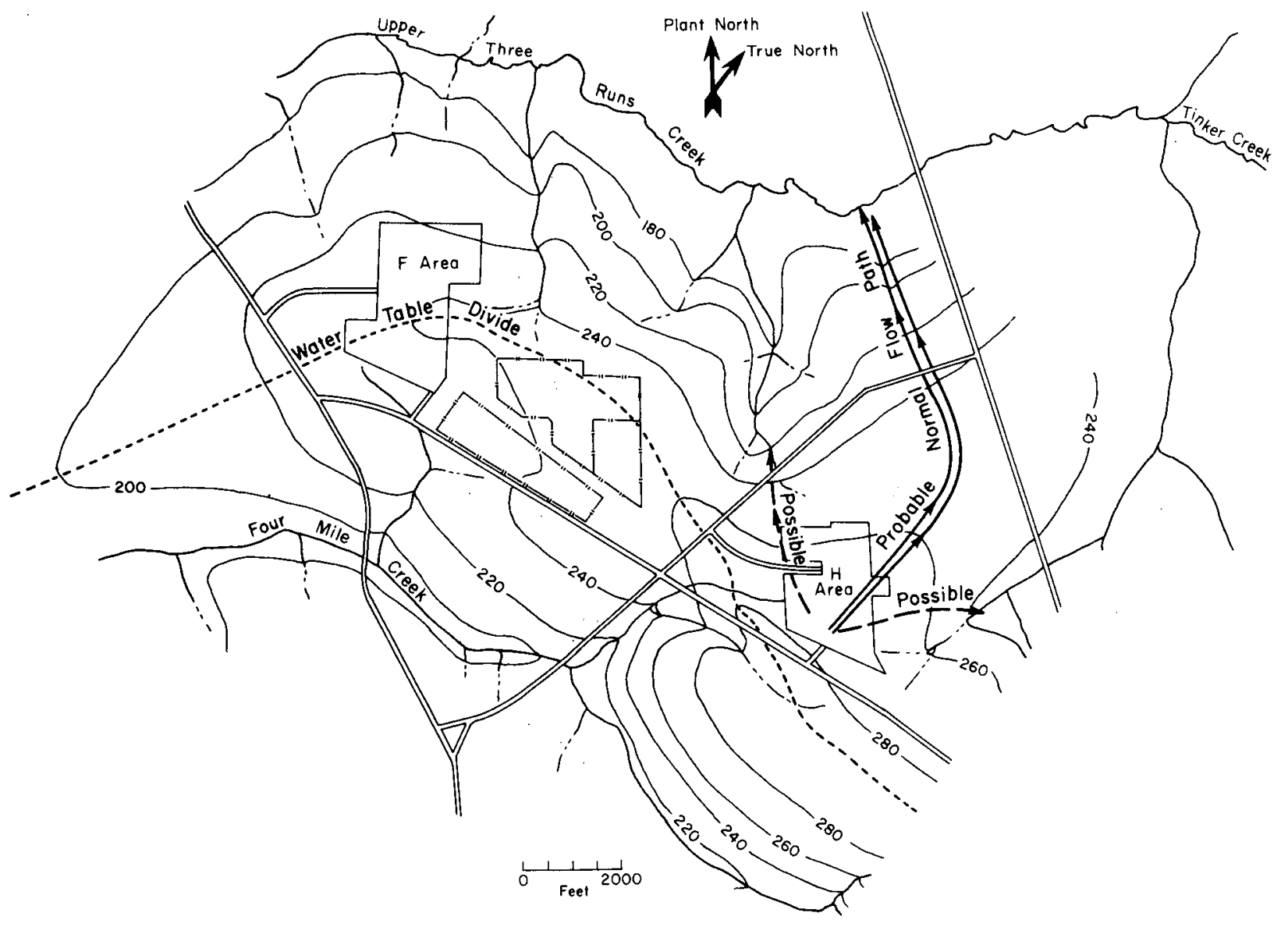

FIG. 18 SURFACE WATER TABLE CONTOUR MAP WITH WATER FLOW ROUTE 
The time required for ground water to travel from the area of the waste tanks to Upper Three Runs has been estimated to be between 70 and 350 years. The former value was obtained using laboratory measurements of hydraulic conductivities and effective porosity and using the shorter flow path discussed above. Fenimore ${ }^{5}$ measured the rate of ground water movement using ari "injectiondetection test" procedure. In this procedure, tritium tracer is injected into the ground water, and the arrival of the tracer in detection wells downstream from the point of injection is timed. Velocities were measured in the H-Area tank farm, near the H-Area tank farm, and at the creek. These results show that the ground water velocity at the H-Area tank farm is 0.01 to 0.02 feet per day and increases to 0.2 feet per day halfway down gradient to the outcrop zone and to 1.3 feet per day at the outcrop zone.

The water pressure contour for the McBean formation is given in Figure 19. The map shows a high contour centered near $\mathrm{H}$-Area tanks, and thus many flow paths exist in this formation. The shortest flow path, also shown on Figure 19, is to a tributary of Upper Three Runs and has a flow length of 4100 feet.

The flow time along the shortest flow path from the area under the tanks in the McBean formation to a discharge point was estimated to be between 44 and 530 years. The lower value was based on an average horizontal hydraulic conductivity determined in laboratory tests on undisturbed samples. The higher range of values was based on an average horizontal hydraulic conductivity determined from the pumping tests. Pumping tests on Wells $1 \mathrm{C}$ and $2 \mathrm{H}$ indicate a flow range of 450 and 530 years, respectively.

In normal water supply considerations, field determinations. of hydraulic conductivity are considered more reliable than laboratory determinations; however, for waste disposal problems, the fastest possible movement rate and point of discharge should also be considered.

The lower zones have not been completely delineated, but at least two zones exist: the sand just below the green clay in the Congaree formation, and the sand in the Tuscaloosa formation.

The few data collected on the sand in the Congaree formation permit the preparation of a map of the water pressure contours, which shows that the pressure surface slopes to the northwest (see Figure 20). The shortest flow path from the tanks to a discharge point, which is northwestward from the tanks to the mouth of a tributary of Upper Three Runs, has a length of 8,000 ft. Based on measured hydraulic conductivity and an effective porosity, the flow time along the shortest flow path in the sand just below the green clay is estimated to be 7,000 years. 
The flow time in the sands in the Tuscaloosa formation was not calculated because the head in sands of the Tuscaloosa formation is greater than the head in the Congaree formation; thus the Congaree formation limits the depth to which surface water can migrate.

Water flow times of 44-530 and 7,000 years estimated above for water flow from below H-Area waste tanks through the McBean and Congaree formations, respectively, to the creek do not include the time necessary for surface water to reach these sub-surface formations. This could add an additional 8-16 years to the flow times given above for the flow through the McBean formations and 12-42 years to the Congaree times.

Being in the Atlantic Coastal Plain, the soils at SRP are sedimentary and stratified texturally. These cause considerable variation in ground water flow rates and ion exchange characteristics. A more specific description of soil directly beneath Tank 16 is not available; however, well logs of the soil in the area of Tanks 13, 14,15 , and 16 were obtained before tank construction began. Figure 21 shows a north-south profile based on these samples. For 20 feet below the tank bottoms the soil is either clayey sand or sandy clay. (The "Unified Soil Classification System" used does not specify the percent clay required for these classifications, but past experience at SRP would indicate at least $30 \% \mathrm{clay}$ in the sandy clay and probably $20 \%$ in the clayey sand.) At about 20 feet below the tank bottoms there is a sand stratum about 5 feet thick and a second of similar thickness about 45 feet below the tanks. Well logs at other locations on the $241-\mathrm{H}$ tank farm show these strata do not extend over 200-300 feet laterally.

The soils in the water shed between $\mathrm{H}$-Area waste tanks and Upper Three Runs Creek are generally considered as clayey sand and sandy clay with some localized sand and/or clay lenses.

An unusual feature of the Hawthorn and Barnwell formations in which Tank 16 is located is the numerous sediment-filled fissures or clastic dikes. 6 Some of these serve as channels of more rapid ground water flow. ${ }^{7}$ As an example, several of these clastic dikes were evident at the H-Area seepage basins which receive large volumes of liquid waste containing very low concentrations of radionuclides. Water has been observed trickling through these fissures from a full basin to an empty or partly filled basin; ${ }^{8}$ also, some seepage basin monitoring wells have had concentrations of radioisotopes that could only be explained by these avenues of rapid ground water flow. 


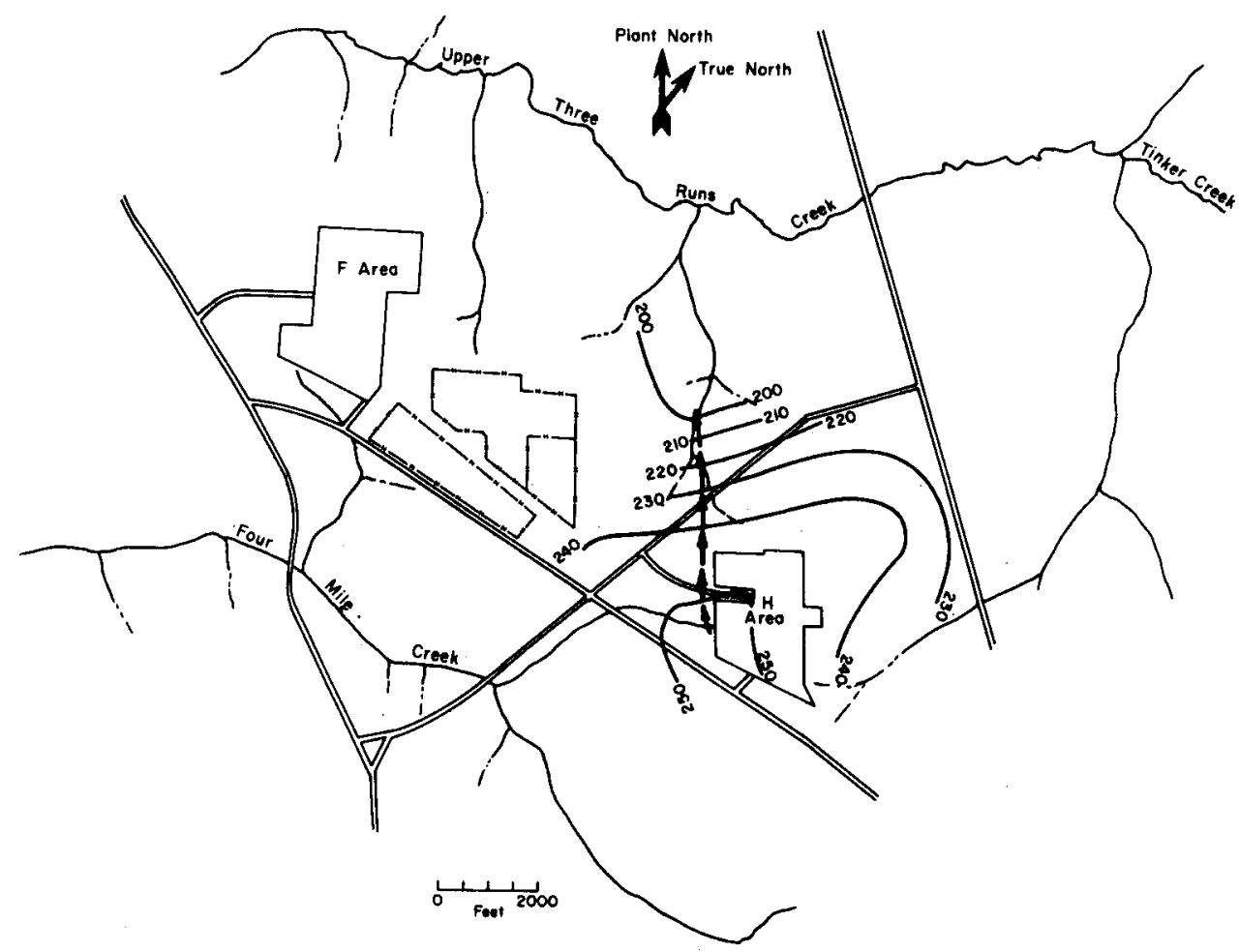

FIG. 19 MCBEAN WATER PRESSURE CONTOUR WITH WATER FLOW ROUTE

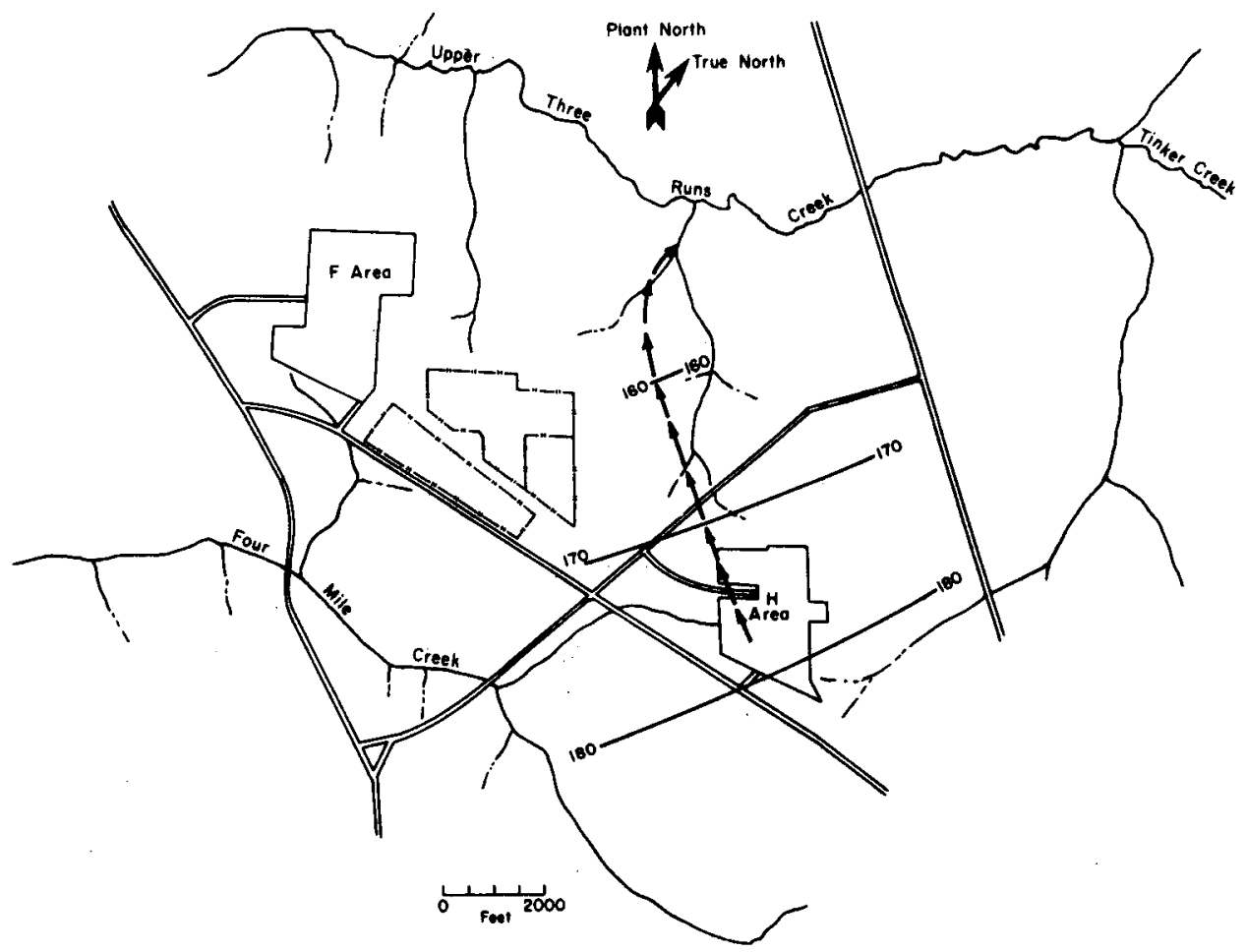

FIG. 20 CONGAREE WATER PRESSURE CONTOUR WITH WATER FLOW ROUTE 


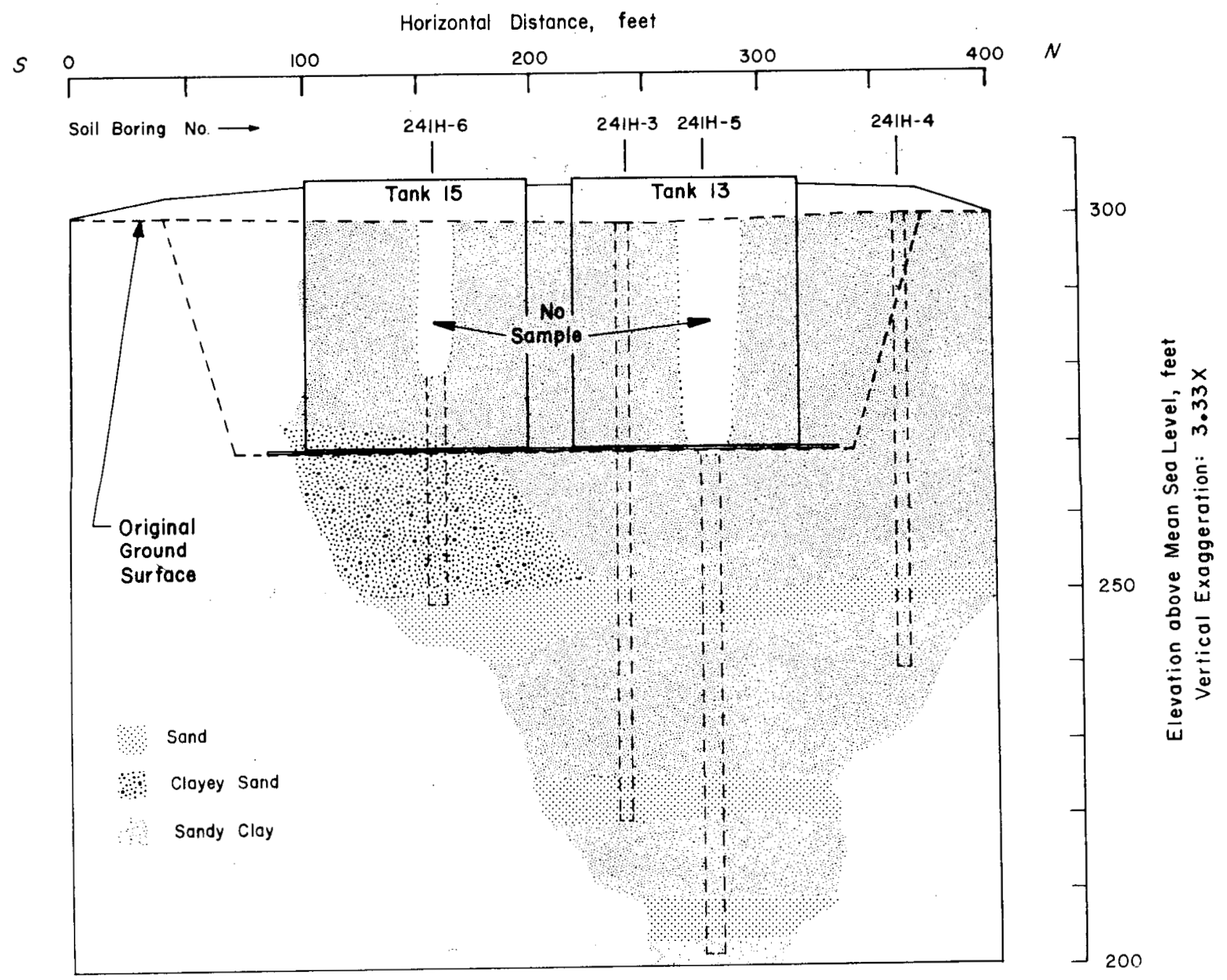

See Figure 2 for relative positions of Tanks 13-76.

FIG. 21 SOIL PROFILE NEAR TANK 16 
A search ${ }^{5}$ was made for such fissures near Tank 16 by measuring the ground water velocity in 53 wells drilled at 22-foot intervals around the west side of the tanks (see Figure 22). These velocity measurements utilized a "point-dilution" test* in which a materialbalance was taken of the tracer while a volume of tracer solution moves out of the well on the down-gradient side, and equal volume of fresh ground water moves in from the up-slope side. The velocity is calculated from changes in concentration. Ground water flow velocities ranged from 0.016 to 0.106 feet per day. The mean for these data was $0.045 \pm 0.022$ feet per day. No wells with high flow rates were found. A statistical analysis of the 53 measured velocities predicts that there is less than one chance in 1000 that the ground water flow velocity will exceed $0.20 \mathrm{ft} /$ day. This indicates that channeling in the vicinity of Tank 16 is expected to be rare and of little significance in the evaluation of movement of radionuclides contained in the waste.

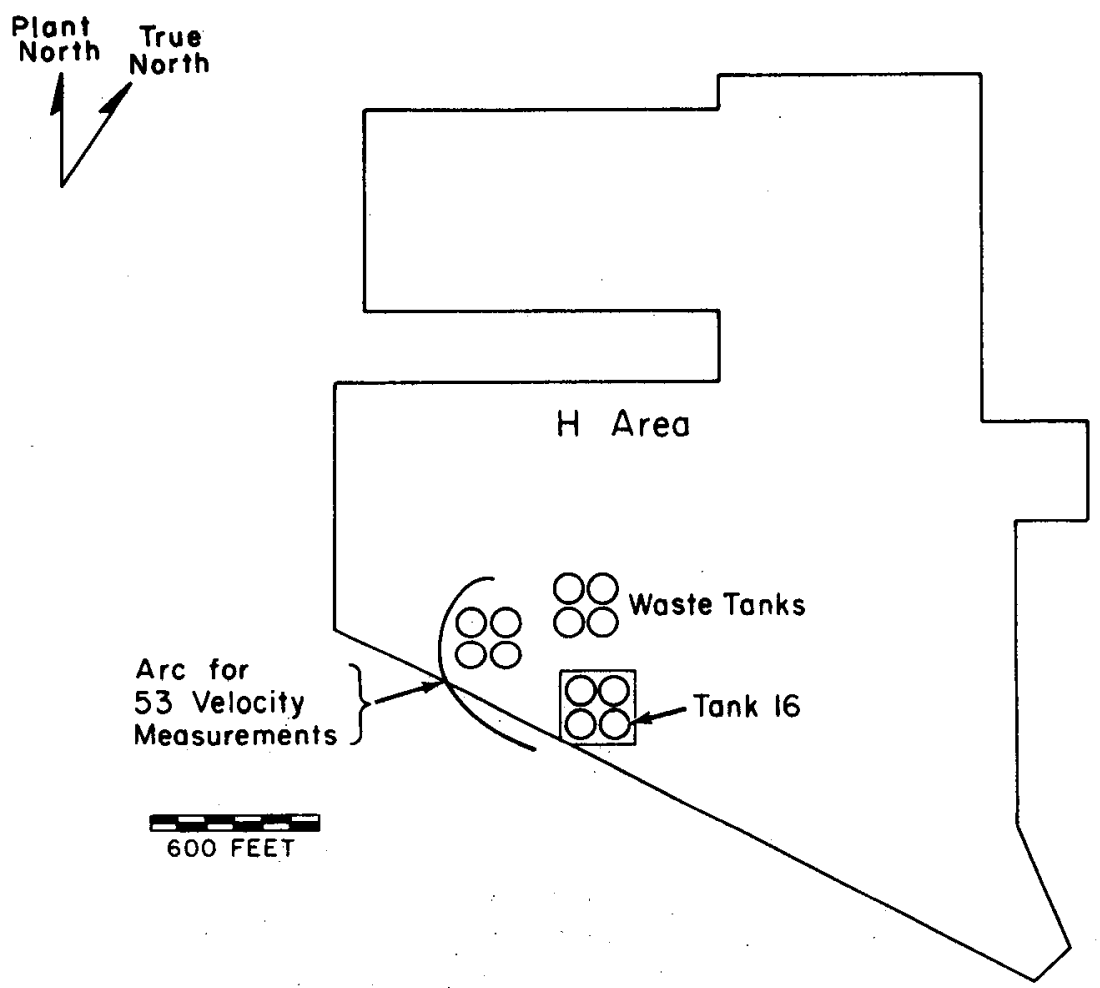

FIG. 22 LOCATION OF GROUND WATER FLOW VELOCITY MEASUREMENTS

* The "point-dilution" method of measuring velocity of ground water movement is not considered as accurate as the "injection-detection" method. Results of measurements using the "point-dilution" method do indicate relative differences. The injection-detection values were used to calculate flow time of water to the creeks. 
The next few paragraphs will discuss ion exchange, cesium fixation, and soil pluggage as they relate to alkaline waste leakage and subsequent release of activity to Upper Three Runs. Additional details are given in Appendix $C$. The principal effect of all of these actions in the soil is to slow the movement of constituents of the waste relative to ground water flow.

Clays are the predominant ion exchange media in the soil. They appear in all soils at Savannah River to some degree. The cation exchange capacities of clays found around the world range up to 150 milliequivalents (meq) per $100 \mathrm{~g}$ of mineral." Kaolinite, the predominant clay of the SRP soil, is reported to have a capacity of 3-15 meq/100 g. The above capacities were measured at $\mathrm{pH} 7$. Prout ${ }^{10}$ measured the ion exchange capacity of samples obtained from soil under the waste tanks and found a capacity of $1.9 \mathrm{meq} / 100$ grams of clay at a pH of 6 . He also found the capacity increased with increasing $\mathrm{pH}$, reaching $6 \mathrm{meq} / 100 \mathrm{~g}$ at $\mathrm{pH} 10$. Based on laboratory distribution data, the order of the rate of movement of chemicals contained in alkaline waste through the SRP soil has been established to be

$$
\text { ground water }=\mathrm{NO}_{3}>\mathrm{Na}>\mathrm{Ru}>\mathrm{Sr}>\mathrm{Cs}>\mathrm{Pu}
$$

(Relative rate of movement is discussed in more detail in the section beginning on page 53. )

The movements of $\mathrm{Sr}, \mathrm{Cs}$, and $\mathrm{Pu}$ are all quite slow due to high ion exchange of these cations with the soil.

Relative rates of movement of $\mathrm{Sr}$ and $\mathrm{Cs}$ in SRP soils indicate that another mechanism increases the measured retention for Cs in this soil, further slowing the rate of Cs movement. Fenimore and Horton ${ }^{8}$ proposed as an explanation of this phenomenon that Cs becomes fixed by the weathered mica minerals in the soil and is only slowly released after fixation:

The alkaline high-activity waste when diluted with ground water causes the kaolinite clay aggregates to disperse and form colloids which plug the soil pores. Clay particles normally exist as aggregates with large pores. The dispersion results in reduced soil permeability and has been determined to reduce the rate of water or waste flow through the SRP soil by a factor of a least 3700 . The pluggage occurs at a sodium concentration of $0.03-0.035 \mathrm{M}$. 


\section{WASTE COMPOSITION}

The primary source of highly radioactive liquid waste is the chemical separations processes where enriched uranium or plutonium is recovered. Liquid wastes are categorized as HAW (high activity waste) and LAW (low activity waste). The HAW contains most of the radioactive fission products processed in the Separations area or concentrated in canyon evaporators. The concentrate is combined with suspended solids from preextraction treatment and neutralized with sodium hydroxide before discharge to waste tanks. The HAW is principally sodium nitrate, sodium aluminate, and sodium hydroxide with some sulfate and carbonate. HAW contains sufficient radioactive fission products to produce a decay heat of 0.5 to $5 \mathrm{Btu} /$ (hr) (ga1). The LAW has a fission product content $1 / 1000$ to $1 / 100,000$ that of HAW and is made up of solutions from secondary solvent extraction cycles and solvent washers. These wastes are concentrated in canyon evaporators and neutralized with sodium hydroxide before discharge to waste tanks.

Tank 16 was initially filled with HAW from enriched uranium processing, and the tank wall first leaked while it contained this HAW. Part of the contents were removed and the leaks sealed themselves by depositing salt in the cracks in the tank wall. After years of no leakage, the tank was refilled with LAW. The following description of the composition of stored waste is for HAW. LAW may be similar chemically but contains less fission products.

High activity. waste received into a waste tank for storage has a dissolved solid content of about 35 weight percent (primarily sodium nitrate and sodium aluminate). While the waste ages, suspended solids settle into a sludge layer at the bottom of the tank. The sludge is a mixture of oxides and hydroxides of manganese, iron, some aluminum, small amounts of uranium, plutonium, mercury, and essentially all of the fission products from the irradiated fuel. Cesium is the major fission product that remains in the supernate. The major chemical and physical properties of aged ( $\sim 10$ years) H-Area wastes are outlined in Tables 4 and 5.

Compositions of the minor components of the waste supernate have been determined from samples obtained from various waste tanks. Somewhat less is known of the sludge components. The non-radioactive minor components of the H-Area waste supernate are given in Table 6. Table 7 gives radioactive elements. Table 7 is representative of wastes that have been cooled $\sim 5$ years.

In aged waste, the principal long-term biological hazards are from the radioactive constituents that are mostly concentrated in the sludge. Cesium is the major exception: Analyses of the sludge layer of ferric hydroxide and manganese dioxide show that it contains greater than $99 \%$ of the strontium and plutonium, about 
$10 \%$ of the cesium (which is thought to be in the occluded supernate), and the mercury. The biological hazards in aged waste from radioisotopes are outlined on page 52 .

\section{TABLE 4}

CHEMICAL COMPOSITION OF H-AREA HIGH ACTIVITY WASTE

\section{Constituent}

Concentration

Supernate

$$
\begin{aligned}
& \mathrm{NaNO}_{3}, \mathrm{NaNO}_{2} \\
& \mathrm{Na}_{2} \mathrm{CO}_{3} \\
& \mathrm{Na}_{2} \mathrm{SO}_{4} \\
& \mathrm{NaAlO}_{2} \\
& \underset{1}{\mathrm{NaOH}} \\
& { }^{3} \mathrm{Cs}
\end{aligned}
$$

$$
\begin{aligned}
& 4-5 \mathrm{M} \\
& 0.1 \mathrm{M} \\
& 0.05-0.1 \mathrm{M} \\
& 0.5-1 \mathrm{M} \\
& 1-1.5 \mathrm{M} \\
& 1-20 \mathrm{Ci} / \mathrm{gal}
\end{aligned}
$$

Sludge

$$
\left.\begin{array}{l}
\mathrm{Fe}(\mathrm{OH})_{3} \\
\mathrm{MnO}_{2} \\
{ }_{9}{ }^{0}(\mathrm{OH})_{3} \\
2{ }^{39} \mathrm{Pu} \\
23{ }^{8} \mathrm{Pu}
\end{array}\right\}
$$

$$
\left\{\begin{array}{l}
\text { Settled Volume } \\
5-8 \% \text { of } \\
\text { supernate volume } \\
10-500 \mathrm{Ci} / \mathrm{gal} \\
3-30 \times 10^{-3} \mathrm{Ci} / \mathrm{gal} \\
2 \times 10^{-1} \mathrm{Ci} / \mathrm{gal}
\end{array}\right.
$$

\section{TABLE 5}

\section{PHYSICAL PROPERTIES OF AGED WASTE}

Supernate

Specific Gravity

Viscosity

Heat Generation, \% of total

(Practically all from cesium)
$1.2-1.4$

$\sim 2 \mathrm{cp}$

50

$1.5-1.8$

Very high

50 


\section{TABLE 6}

LOW CONCENTRATION

NONRADIOACTIVE CONSTITUENTS OF H-AREA SUPERNATE

Constituent

$\mathrm{CO}_{3}{ }^{-2}$

$\mathrm{SO}_{4}-2$

$\mathrm{PO}_{4}^{-3}$

$\mathrm{Cl}^{-}$

$\mathrm{CrO}_{4}^{-2}$

$\mathrm{F}^{-}$

$\mathrm{Fe}$

$\mathrm{Hg}$

$\mathrm{NH}_{4}{ }^{+}$

$\mathrm{Ag}$

$\mathrm{Pb}$

$\mathrm{U}$

Reducing normalities
Concentration

$<0.1-0.3 \mathrm{M}$

$0.02-0.08 \mathrm{M}$

$<0.01-0.05 \mathrm{M}$

$0.005-0.029 \mathrm{M}$

$0.001-0.005 \mathrm{M}$

$0.001-0.004 \mathrm{M}$

$6 \times 10^{-5}-0.2 \mathrm{M}$

$60-340 \mu \mathrm{g} / \mathrm{m} 1$

$<1-67 \mu \mathrm{g} / \mathrm{m} 1$

$0.1-4 \mu \mathrm{g} / \mathrm{m} 1$

$2-58 \mu \mathrm{g} / \mathrm{ml}$

$0.4-6 \mu \mathrm{g} / \mathrm{m} 1$

$<0.01-0.3 \mathrm{~N}$

TABLE 7

RADIOACTIVE CONSTITUENTS OF H-AREA SUPERNATANT WASTE

Constituent

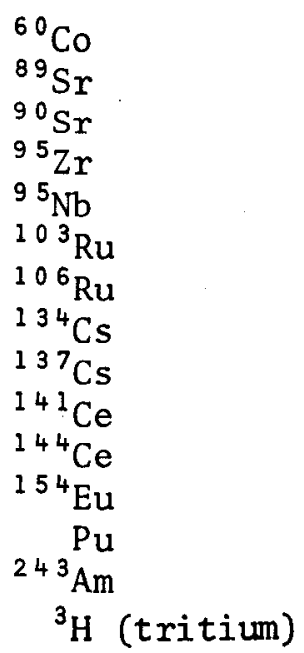

Concentration, $\mu \mathrm{Ci} / \mathrm{gal}$

$<3-12$

$<0.3-<35$

$30-3,600$

$<5-<10$

$<1-2$

$<2-4,900$

$1,500-6,800$

$100,000-170,000$

$1,000,000-20,000,000$

$<1-<44$

$<8-<440$

$<3-5$

$0.01-240$

$<1-4$

$\sim 75$ 
- Cesium-137, a 30-year half-1ife fission product, is a gamma emitter with a specific activity of 87 curies per gram. Its concentration in the supernate is 1 to 20 curies per gallon.

sludge

- Strontium-90, a 28-year half-life fission product, is a beta emitter with a specific activity of 142 curies per gram. Its concentration in the sludge is 10 to 100 curies per gallon.

- Plutonium-238, an 87-year half-1ife actinide, is an alpha emitter with a specific activity of 17 curies per gram. Plutonium-238 is the predominant plutonium activity in the $\mathrm{H}$-Area waste for the first 800-1000 years. Its concentration in the sludge approaches 0.2 curies per gallon.

- Plutonium-239, a 24,000-year half-1ife actinide element, is an alpha emitter with a specific activity of 0.06 curies per gram. Its concentration in the sludge varies from 3 to 30 millicuries per gallon.

As indicated on page 24 , the waste that overfilled the Tank 16 annulus pan had not completely separated into sludge and supernate. The waste supernate phase, which leaked into the annulus, contained more $\mathrm{Sr}, \mathrm{Zr}-\mathrm{Nb}$ and $\mathrm{Ru}$ than the supernate listed in Table 7. Radiation and temperature profiles of the tank confirm this conclusion by indicating the sludge layer was only $30 \%$ of its expected final level. Slow settling of the sludge results from 1) the careful controls, which maintain a high hydroxide-to-aluminum ratio in the neutralized waste, to ensure the waste will stay as a solution while being handled, and 2) thermal agitation of the waste sludge from fission product decay heat release. Of the radionuclides present in the waste that leaked into the soil, ${ }^{137} \mathrm{Cs}$ is in the largest quantity and has the largest biological hazard. The ${ }^{90} \mathrm{Sr}$ concentration is relatively low $(0.13 \mathrm{Ci} / \mathrm{gal})$ but is still of concern. ${ }^{95} \mathrm{Zr}-{ }^{95} \mathrm{Nb},{ }^{10}{ }^{\mathrm{Ru}}$, and ${ }^{106} \mathrm{Ru}$ were present in 1 ow concentrations at the time of the leak, and due to their relatively short half lives $\left({ }^{106} \mathrm{Ru}\right.$ has the longest half 1 ife and it is 1 year) have decayed to less than $1 \times 10^{-4} \mathrm{Ci} / g a 1$ in the 14 years since the leak, and do not pose a significant hazard. This latter group of radionuclides is not treated in the following sections on migration of waste through the soil. 


\section{QUANTITATIVE DESCRIPTION OF RADIOACTIVITY MIGRATION IN SOILS}

If aqueous waste enters the ground above the water table, it percolates downward through the porous subsurface soil to the water table. When it reaches the water table (saturated zone), the waste will be diluted by ground water and will move horizontally and downward with the ground water through the saturated zone (below water table). If the aquifer is homogeneous and isotropic, the mechanism of transport and dispersion of ions in the porous medium may be described as follows: ${ }^{11,12}$

- Following introduction of a discrete quantity of a radioactive material into the ground, the center of distribution of the radioactivity will be influenced mainly by the motion of the ground water that transports and disperses the contamination, and by the sorptive capacities of the sediments of the aquifer, which delay the motion of each contaminant to various degrees.

- The envelope of contamination, originally spherical, will enlarge and elongate in the direction of flow. The concentration distribution of ions (1ongitudinally, transversely, and vertically) will approach the normal probability distribution (become Gaussian) after traveling a short distance. The standard deviation of the ion dispersion about the center of distribution will increase as the square root of the distance traveled and will be essentially independent of the velocity of the ground water or the sorbing ion.

- The envelope of contamination will under these conditions take on the shape of a prolate spheroid, or "football", having a size dependent both on the distance traveled and on the concentration of waste materials that is representative of the surface of the envelope beyond which the contamination can be considered negligible. 
As discussed earlier, the principal effects of soil chemistry (ion exchange and cesium fixation) are to reduce the movement of constituents of the waste relative to ground water flow. According to Simpson, 11

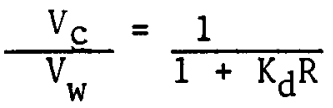

gives a good approximation of the relative rates of travel of the contaminants and the ground water. In this equation, $V_{C}$ is the average velocity of the contaminant, $V_{W}$ is the velocity of the ground water, $K_{d}$ is the distribution coefficient for the contaminant between the soil and ground water, $R=\rho[(1-\varepsilon) / \varepsilon], \rho$ is the bulk density of the soil, and $\varepsilon$ is the porosity. $R$ is about 3.5 for SRP soil $(\rho \sim 1.5$ and $\varepsilon \sim 0.3)$.

The distribution coefficient, $K_{d}$, may be regarded as a practical measure of the relative affinity of ions for the soil. By determining $K_{d}$ values under controlled conditions ( $\mathrm{pH}$ and ion concentration), it is possible to establish the average velocity of ions through the sediment, when the average velocity of the ground water is known. Laboratory-measured $K_{d}$ data in SRP soils $\mathrm{s}^{13}$ are given in Figure $\mathrm{C}-1$ of Appendix C. For a $\mathrm{pH}$ of 7.5 , the distribution coefficients are Sr, 800; Cs, 1000; and $\mathrm{Pu}(\mathrm{IV}), 8000$. These $\mathrm{K}_{\mathrm{d}}$ values indicate the relative rates of movement would be

Isotope

Movement of RadioIsotope Relative to Water

$$
\begin{array}{lll}
\mathrm{Sr} & >\mathrm{Cs} & >\mathrm{Pu}(\mathrm{IV}) \\
3.6 \times 10^{-4} & >2.9 \times 10^{-4}>3.6 \times 10^{-5}
\end{array}
$$

The relative movement of ruthenium has not been measured, but ruthenium chemistry indicates its rate may approach that of the ground water (see Appendix C).

The $K_{d}$ values measured by Prout and given in Figure $\mathrm{C}-1$ were measured on absorption and do not include the effect of cesium fixation, which further slows the movement of cesium relative to ground water and other radioisotopes. If the alkaline waste causes the kaolinite clay aggregates to disperse and form a plug, the rate of flow of both ground water and waste contaminants decreases in the vicinity of the plug.

In natural formations, the soil is neither homogeneous nor isotropic; thus uniform water flow rates cannot be expected. Channeling, which would increase soil permeability, might occur in the SRP soil (see page 47). Channeling tends to change the rates of flow of water and radioisotopes, but not their relative movement. 
Parsons ${ }^{14}$ at Chalk River, Canada, developed data on the extent of migration of radioactive material injected into the ground at three different disposal sites. An analysis of his data by Prout and Proctor confirms that dispersion follows normal probability distribution, both in the transverse and longitudinal directions. Standard deviations for the longitudinal dispersions were between 3 and 7 times that of the transverse dispersion, and at 300 feet from the point of injection, the transverse standard deviation was about 25 feet. The standard deviation of isotope dispersion for SRP is assumed to be the same as that calculated from the Chalk River data since the soil structure at both sites is similar (predominately sandy clay and clayey sand).

An important inference can be drawn from the supposition that the concentration gradients follow the normal probability curve illustrated in Figure 23. Since in this study the region of contamination of principal concern is one in which the concentration of the radionuclide is above the recommended concentration guide (CG) level for water, it is necessary to include within the envelope distances equivalent to six or seven standard deviations in each direction. These very wide limits result from the extremely low concentration represented by the CG value.

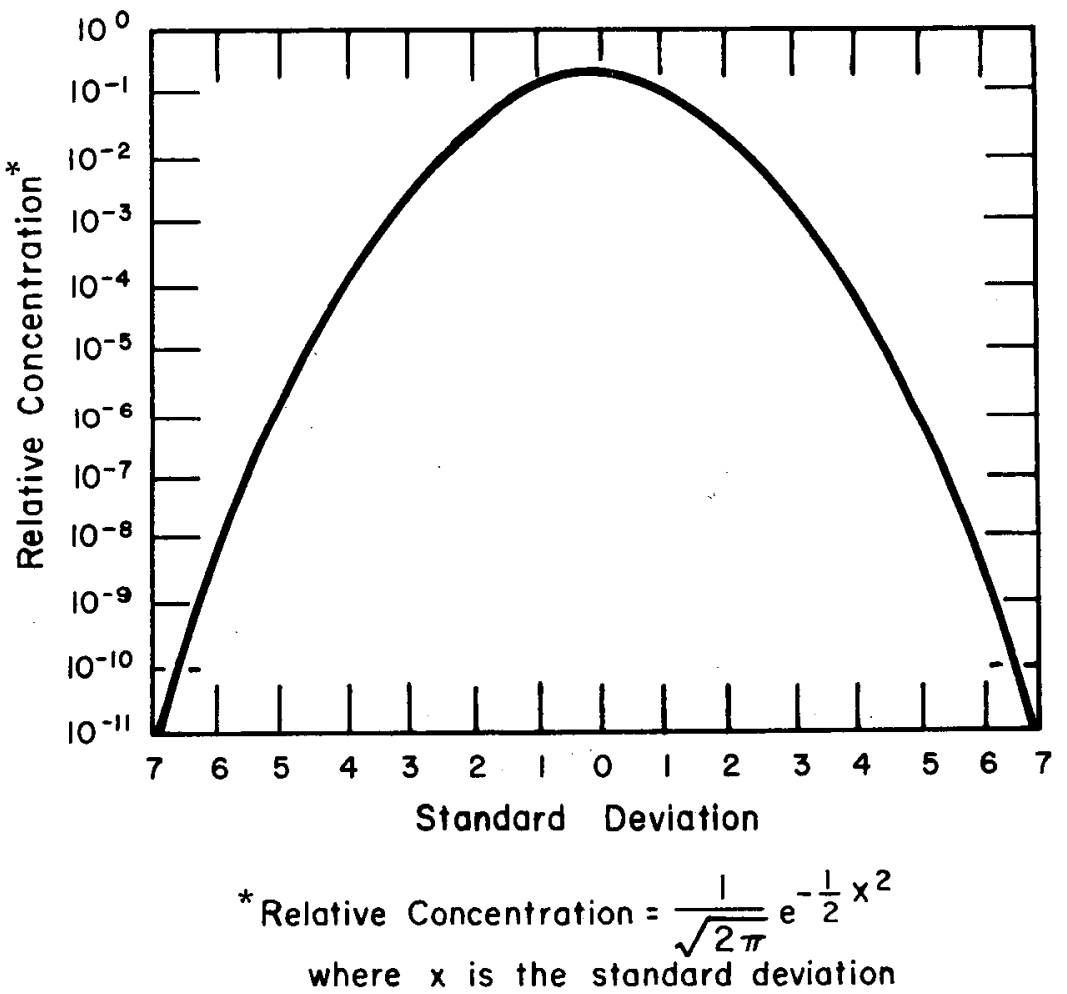

FIG. 23 PROBABILITY CURVE 
Inspection of the curve in Figure 23 shows that because the relative concentration decreases very steeply above three standard deviations, the size of the envelope of contamination is quite insensitive to the level of concentration in the center of the envelope. For example, if the center concentration were increased by a factor of 100, the envelope of contamination would be increased by only one standard deviation, or about 15 percent. This leads to the conclusion that analysis of movement through soil structures will be quite insensitive to the initial assumptions of activity leakage into the soil. A leak 10 to 100 times that assumed would not substantially increase the size of the envelope of contamination, but would only increase the severity of the contamination within the envelope. By contrast, at the point where the radioactive contaminant discharges from the soil into a creek or other surface formation, the quantity of contaminant is a direct function of the initial leak rate and concentration decreased by the radioactive decay that occurs in transit.

If waste were to leak into saturated soil below the water table, the rate of movement of its contained radionuclide can be calculated from the movement parameter given by Simpson and de Jong. The envelope containing the contamination will expand slowly from a spherical shape and take on an ellipsoidal shape. The rate of radioactivity movement is controlled by the ground water flow rate and ion exchange with the soil. Radioactivity will spread around the center of radioactivity due to dispersion. This dispersion would be caused by molecular diffusion, random flow path selection, inhomogeneities in the soil, etc. If the dispersion parameters observed at Chalk River are used, a one-time leak of activity will produce an activity finger. If the waste leakage was spread over a large area, as may have happened while pumping the water addition system, the radioactivity profile can be thought of as a radioactivity front. This radioactivity front should proceed at the same rates as determined from a point leak. Figure 24 gives the isoconcentration fronts that precede 50,85 , and $99.8 \%$ of the radioactivity of several radionuclides of the waste. Tritium is assumed to have zero sorption capacity and thus moves with the ground water at a rate of $0.01 \mathrm{ft} / \mathrm{day}$. Strontium and cesium movement were determined using distribution coefficients of 800 and 1000 , as measured by Prout at a pH of 7.5. If the flow rate of ground water is other than this rate, the location of the contaminant can be determined by dividing ground water flow rate by 0.01 , then multiplying by the values determined from Figure 24 . 


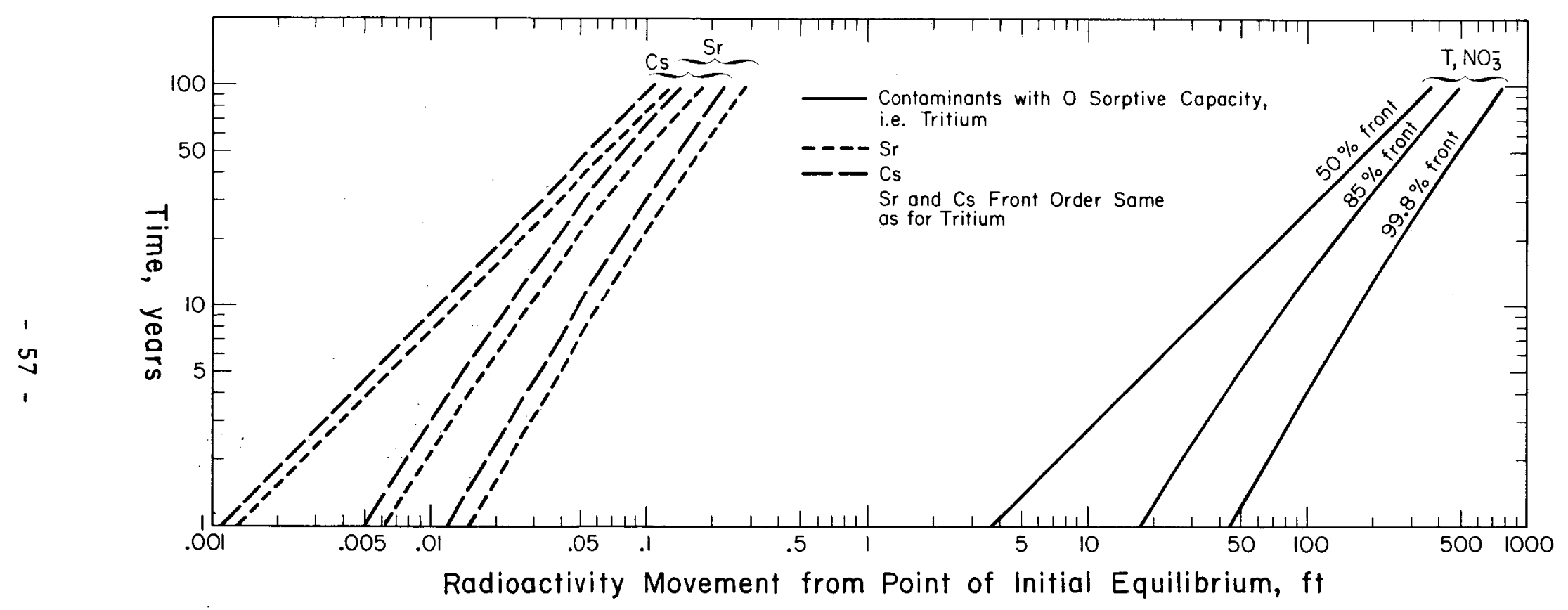

FIG. 24 CONTAMINANT FRONT PROFILE

Assumed ground water flow rate $0.01 \mathrm{ft} /$ day 


\section{APPLICATION TO TANK 16 LEAK}

As discussed on page 43 , the ground water flow rate near the area of the waste tanks is about 0.01-0.02 ft/day. In the intervening 14 years since the Tank 16 annulus pan was overfilled, the ground water would have moved 47 feet* toward the creek. During this time the centroid of radionuclides with no sorptive capacity for the soil (for example, tritium) would have moved a like distance. Due to dispersion, the tritium activity would be extended both ahead and behind this average. About $15 \%$ of the tritium that entered the ground would have moved more than 95 feet, * but only $0.2 \%$ would have moved more than 200 feet.*

Radioisotopes of cesium and strontium are delayed by ion exchange with the soil and, in the 14 years since the overfill, would have traveled a much shorter distance than tritium or the ground water. Calculations show that the central section of these isotopes would have moved only about 0.01 foot* from the point of initial equilibrium with the soil. (Before radioisotope equilibrium is attained, equilibrium of the major components of waste -- $\mathrm{NaNO}_{3}, \mathrm{NaOH}$, etc.-with the soil must be attained. Rough estimates indicate this requires about $100 \mathrm{ft}^{3}$ soil/gallon of waste.) Dispersion should increase the distance of the leading edge of cesium and strontium to about 0.1 foot* from the point of initial equilibrium.

The section on hydrology of the waste tank farms (Page 37) discusses the times necessary for water from the area of the waste tanks to reach the creeks. These data are summarized in Table 8 . The data indicate that the flow times range from a minimum of $52-70$ years to a more likely flow time of $350+$ years. For the assumed minimum value of 52 and the more likely 350 years for the ground water flow times to the creek and the populated areas, time for cesium and/or strontium to reach the public domain can be estimated. The leading edge, which precedes $99.8 \%$ of the cesium or strontium radioactivity, will not reach the creek for $1 \times 10^{5}$ to $8 \times 10^{5}$ years. The central section of this radioactivity would be delayed for $2 \times 10^{5}$ to $12 \times 10^{5}$ years. In any of these time periods, radiocesium or radiostrontium would have completely decayed, leaving harmless solutions of stable barium or zirconium. These estimates do not consider soil dispersion and pluggage nor cesium fixation discussed in the previous section.

* Assumes an average ground water flow rate of $0.01 \mathrm{ft} / \mathrm{day}$. 
TABLE 8

GROUND WATER FLOW

\begin{tabular}{|c|c|c|}
\hline \multirow{3}{*}{$\begin{array}{l}\text { Geological } \\
\text { Formation }\end{array}$} & \multicolumn{2}{|c|}{ Ground Water Flow Path } \\
\hline & Distance from & Estimated Flow \\
\hline & Waste Tanks, $\mathrm{ft}$ & Time, years \\
\hline Hawthorn-Barnwel 1 & $2500-9000$ & $70-350$ \\
\hline McBean & 4100 & $52-546^{a}$ \\
\hline Congaree & 8000 & $7000^{b}$ \\
\hline
\end{tabular}

a. Includes 8-16 years for vertical flow and 44-530 years for horizontal flow.

b. Vertical flow time not significant in view of the long 7000-year horizontal time.

Increased soil permeability or channeling appears to be the most plausible possibility that could increase the rate of water flow to the creek. The experimental program to locate areas of channeling near Tank 16 was discussed on page 47 . Soil permeabilities measured in the experimental programs showed that permeabilities ranged only a factor of ten, and statistical analyses of these data indicate areas with higher permeability are rare. Even if assumed channeling increases flow and reduces travel time by a factor of 10-100, the delay time in the soil is still sufficient to allow complete decay of radiocesium and radiostrontium to their stable daughter products.

The above calculations assume climatic conditions, hydrology, and ground water usage remain unchanged during the periods covered by the calculation. In times as 1ong as hundreds of thousands of years, some of these conditions might change. If the above conditions were assumed to continue for 100 years on $1 y$, and sixteen gallons of waste were discharged into Upper Three Runs Creek in the period of one day, then the radioactivity of cesium in the creek would be just below the Concentration Guide Level for cesium $\left(1.9 \times 10^{4}\right.$ compared to $\left.2.0 \times 10^{4} \mathrm{pCi} / 1\right)$ for that one day period. Upper Three Runs Creek waters would be further diluted by a factor of 50 upon mixing in the Savannah River. The assumption of discharge of the total quantity of radioactivity to the creek in a one day time period is very conservative since the radionuclides of the waste would be dispersed over a reasonably wide area of soil, and release to the creek would require much more time than one day. Two possible times for discharge to the creek under this scenario are given below.

1. If one were to assume no ion exchange capacity of the soil and the radioactivity moved at the same rate as the ground water, the radioactivity would be spread ahead of the centroid of radioactivity 350 feet after one hundred years. If a like 
distance were assumed for spreading of radioactivity behind the centroid, the radioactivity would be spread over 700 feet and at a ground water flow rate of $1.3 \mathrm{ft} /$ day (measured rate at outcrop to creek) it would require about 1.5 years to discharge into the creek.

2. If one were to assume the expected ion exchange, the radioactivity would have moved only a few feet from the point of initial leakage and would be spread over a much smaller area. Using the same rationale as above to determine the amount of soil occupied by the radionuclides after 100 years and assuming a ground water flow velocity of $0.01 \mathrm{ft} /$ day (rate near the waste tanks) and further assuming that ion exchange ceases after 100 years and the radionuclides are washed directly to the creek, it would require 30 days for the radioactivity to wash into the creek. 


\section{EVALUATION AND CONCLUSIONS}

The estimated 700 gallons of waste that exceeded the level of the steel annulus pan places an upper limit on the amount that could have escaped from the tank into the ground. This 700 gallons contained 5,200 curies of radioactivity. The actual amount of waste that leaked into the soil is not known, but the monitoring data indicate that some radioactivity did reach the soil. The inleakage of waste into the annulus pan, detected in January-February 1972, supports the conclusion that some of the 700 gallons of waste probably never left the concrete encasement. The next several paragraphs summarize information on the amount of waste that may have leaked into the soil, its path, and possible consequences. Major conclusions are given in italics.

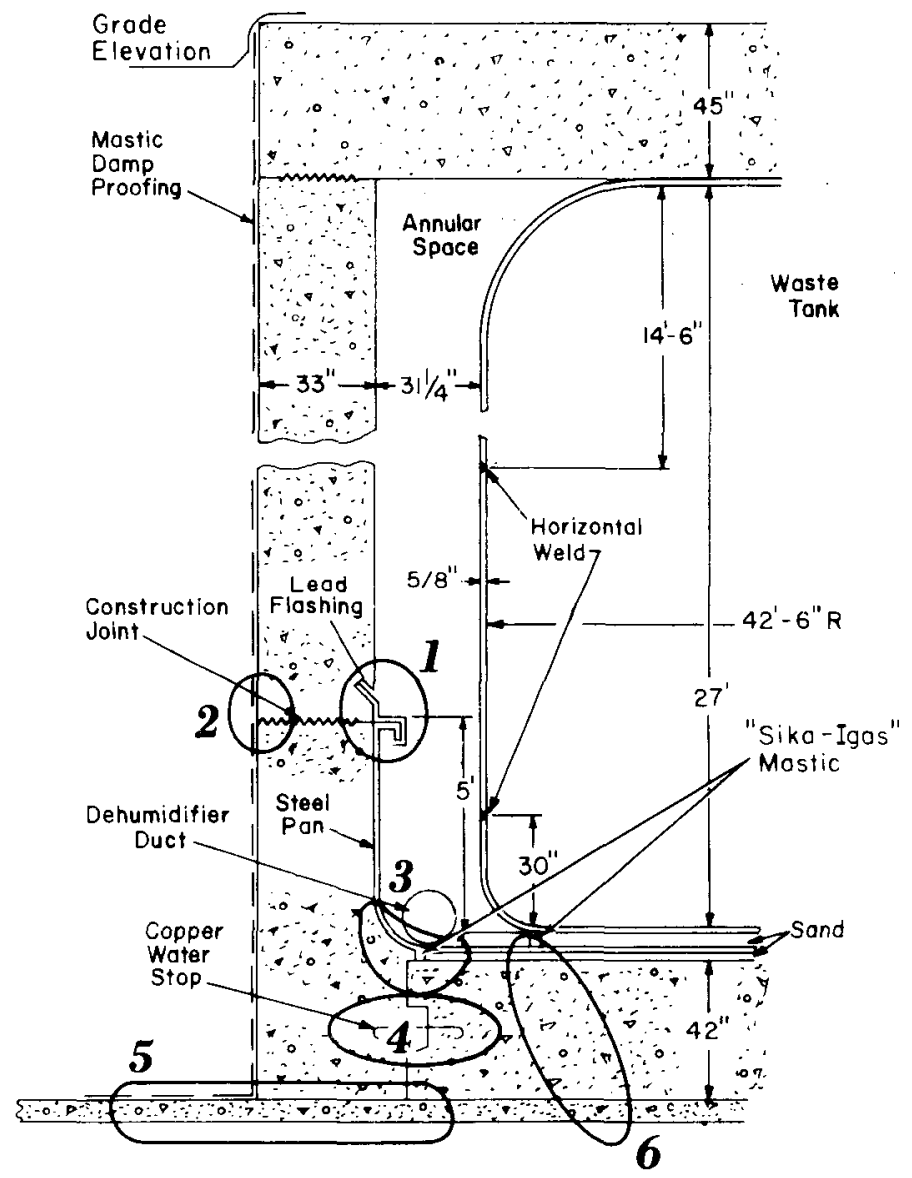

Figure 25 shows a section of Waste Tank 16 with numbers designating areas that are significant to possible leak paths. Enlargements of these areas are shown on the following pages with descriptions of possible flow paths. In summary, it appears most likely that leakage from this tank was through the construction joint located at the level of the top of the steel annulus pan. This joint probably weeped from several zocations when placed under the hydrostatic head resulting from the overfizl of the annulus pan. The maximum leakage was probably about sixteen galzons.

FIG. 25 SECTION OF WASTE TANK 16 ENCASEMENT 
AREA 1 - The waste in the steel annulus pan exceeded the top of the pan on September 8, 1960, for approximately six hours. If no leakage occurred during this time, the level would have reached 1.5 inches* above the top of the annulus pan (see Figure 4, page 23). Thus the maximum head that could force waste from the tank was 1.5 inches. For waste to escape from the annulus pan, the waste would have to circumvent or penetrate the lead flashing shown on the first view below. (This lead was installed to direct condensate, rain, or ground water inleakage above this level into the steel annulus pan.) Flow path 1 (over the flashing) is an improbable path since the upper surface of the lead flashing is located 4 inches above the top of the pan, and the maximum level of waste was only 1.5 inches above the top of the pan. Thus, waste must have gone either through holes in the lead flashing or under it, both of which seem reasonable possibilities.

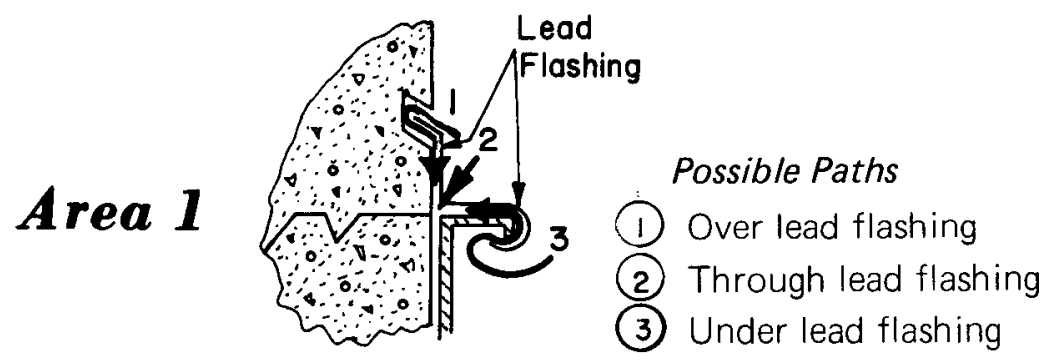

Once having circumvented the flashing, the waste would have two possible paths: through the construction joint or down between the pan and the concrete encasement. The flow directions would

(4) Through construction joint

(5) Between pan and concrete encasement

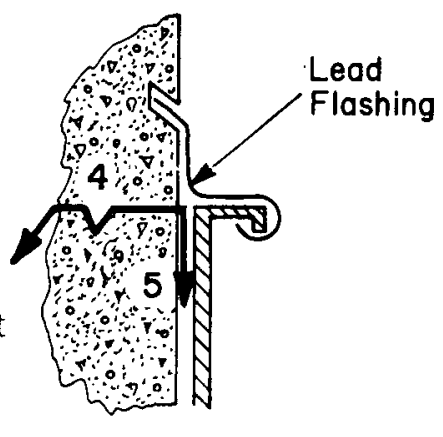

*This head was estimated from a straight line extrapolation of the leak rate and the measured levels in the annulus and assumes none of the waste leaked from the annular space via flow paths 1,2 , and 3 . 
depend upon the resistance each offered to the flow.

- The construction joint probably is not as watertight as the monolithic pours of either the upper or lower side walls of the concrete encasement. It can, however, be visualized as a very thick joint between concrete blocks. On setting, concrete tends to shrink, and a crack may have opened through this joint that would weep when put under a hydraulic head; the reinforcing steel would tend to minimize this shrinkage.

- The flow path between the lower encasement side wall and the steel annulus pan would not be expected to be as tight as that in the construction joint, even though the annulus pan was used as the inner form for this pour. Shrinkage as the concrete cured would probably leave a space between the pan and the encasement wall. The width of the space probably varies as the temperature differential between the annulus pan wall and the concrete encasement varies.

Flow velocities on the order of 10 to 20 feet per hour would be required for the maximum volume of waste that exceeded the top of the annulus pan to have escaped through either of these two paths. Flow velocities of this magnitude could not have been developed with the estimated 1.5-inch maximum solution head available. This seems to substantiate the supposition that a significant fraction (probably a large fraction) of the 700 gallons of waste never left the annular space, but was transferred to Tank 14 when the contents of the annulus pan were transferred. The waste that did flow out of the annular space probably split, most of it following flow path 5 and the lesser amount probably through flow path 4 . The flow velocities discussed above were calculated from the following assumptions :

- The flow space for flow path 4 was $1 / 32$ inch wide all the way around the tank (flow area: $0.776 \mathrm{ft}^{2}$ ).

- The flow space for flow path 5 was $1 / 16$ inch wide all the way around the tank (flow area: $1.55 \mathrm{ft}^{2}$ ). (The assumed $1 / 32$ and $1 / 16$ inch spaces are probably much larger than the actual spaces.)

- Maximum head available to drive flow was 1.5 inches.

- Maximum volume of waste was 700 gallons.

- Flow time available was 6 hours. 
AREA 2 - Waste that flowed through the concrete construction joint would have three further paths (or combinations) before reaching the soil as shown on Area 2 below. It is likely that the damp proofing and its protective layer (abrasion protection) around the tank would not provide guarantee against waste reaching the soil, but would offer additional resistance to flow. If the assumptions used in calculating flow velocities were used to calculate a volume that would be stored in the construction joint, 16 gallons. could be held up for leakage into the ground after the overfill of the annulus pan had been corrected. Monitoring around the tank after the overfill indicated that some radioactivity did reach the soil. Low concentrations of radioactivity were found at several locations around the tank circumference. All of the radioactivity was found either at the construction pad or below it. This may indicate with respect to Area 2 flow paths that it was easier for waste to flow to the damp proofing and then down to the construction pad via paths 7 and 8 . Soil pluggage from diluted waste dispersing the clay of the soil would limit flow via path 6 .
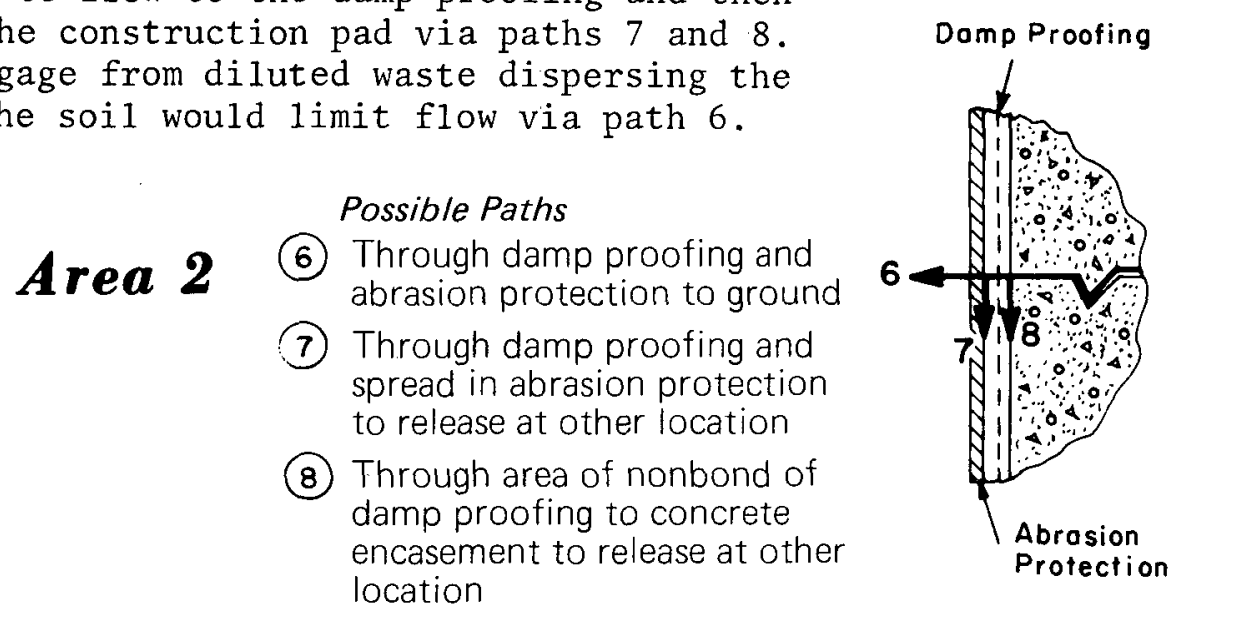

$A R E A 3$ - This area shows another possible flow split. The rate of flow along path 10 would be impeded by the "Sika-Igas" gasket installed between the base pad of the concrete encasement and the steel pan to contain the one-inch sand layer. Waste could flow into and be impeded by the construction joint between the base pad and the lower side wall of the encasement (path 9).

\section{Possible Paths}

(9) Between pan and concrete encasement to joint between base pad and side wall of encasement

(10) Same as(9) except leak into sand between base pad of encasement and pan bottom

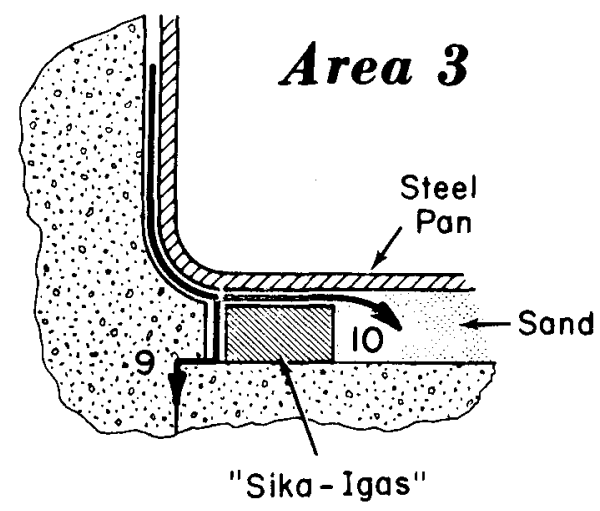


Areas 4 and 5 - Areas 4 and 5 show possible leakage paths for waste proceeding down path 9 in Area 3. The copper water stop used in this tank is effective and has been used to leakproof construction joints with much larger hydrostatic heads. This construction joint would impede flow as discussed above in Area 1; in addition, the water stop would be expected to stop further flow. The area between the top of the pan and the "Sika-Igas" gasket and the copper water stop could contain 290 gallons of waste if a 1/16-inch gap around the tank and a 1/32-inch gap in the construction joint were assumed. This probably fixes a maximum on the amount of waste that could have leaked through path 5 .

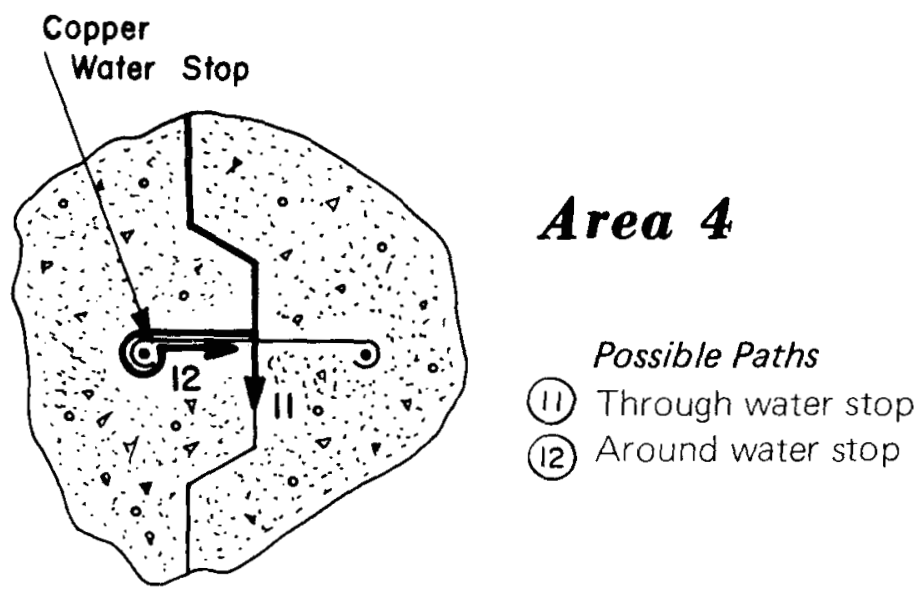

If the water stop were breached, which seems unlikely, the remainder of the construction joint and the construction pad would further impede flow of waste to the ground. The construction pad (Area 5) is known to have cracked, and monitoring showed the connection of some of the wells above the pad to the water addition system below the pad. The pad does, however, add another barrier to the leakage and requires lateral movement to reach a crack.

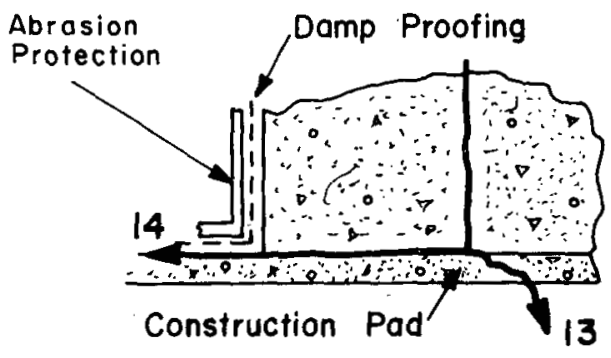

\section{Area 5}

\section{Possible Paths}

(13) Between base pad and side wall of encasement, then through crack in construction pad

(14) Between base pad and side wall of encasement, then between side wall and construction pad to outside edge of tank 
$A R E A 6$ - If waste has moved via flow path 10 (Area 3) into the sand layer, the sand has sufficient capacity to contain the entire amount of the overfill. For radioactivity to leak from the sand it would have to go through a crack in the base slab of the tank encasement. This is unlikely, since stress calculations indicate this base slab should have no cracks that disrupt its monolithic integrity. Minor cracks that penetrate the inner surface to the reinforcing rods are a possibility.

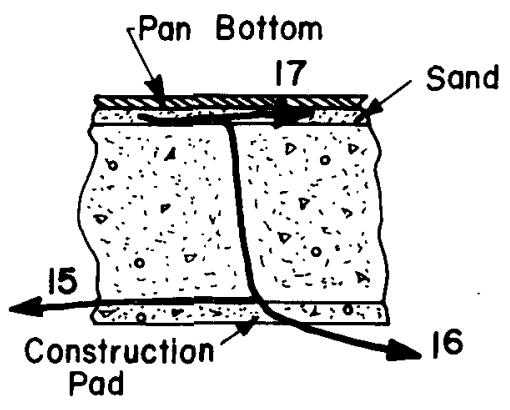

\title{
Area 6
}

\author{
Possible Paths \\ (15) From sand layer through crack \\ in concrete encasement base pad \\ to construction pad, then between \\ base and construction pad to edge \\ of tank \\ (16) Same as (15) except through crack \\ in construction pad to ground \\ (17) Remains in sand
}

If one were to postulate a crack in the lower section of this concrete encasement, hydraulic equilibrium inside and outside the concrete encasement would further limit the volume of waste that could have leaked via flow path 5, Area 1. At the time of the overfill the ground water level was 2.9 feet below the top of the annulus pan. If 2.9 feet of ground water were within the concrete encasement (outside the steel annulus pan), the free space below the top of the steel pan would be reduced from the 290 gallons discussed on page 65 to $\sim 30$ gallons. For more than 30 gallons of waste to enter this area, it would be necessary to displace some of this ground water. In view of the short time the level of waste exceeded the top of the annulus pan, significant outflow through this postulated crack in the concrete encasement would not be expected.

A significant portion of the waste that overfizled the annuzus pan was apparently contained by the concrete encasement and probably never escoped from the concrete encasement into the soil. This hypothesis was at least partially substantiated when solids were observed to have leaked back into the annulus pan from the concrete encasement on the January-February 1972 annulus inspection. Although neither the date nor the amount of inleakage can be determined, the salt deposits indicate the inleakage occurred around the circumference of the tank generally. Only one area inspected had no visible salt deposits. The most likely scenario of this inleakage is as follows: a) Some waste was retained in the construction joint and/or in the sand layer that separates the bottom of the annulus pan from the concrete encasement. (This layer has a calculat,ed free volume 
equivalent to 21800 gallons.) b) Ground water leaked into the concrete encasement through the construction joint (five feet above the bottom of the tank) during periods of high water table levels. c) This water dissolved the salt deposits from old evaporated waste if present, and diluted or displaced the waste, and then finally leaked slowly back into the annulus pan. d) The dehumidification air evaporated the water, leaving the salt deposits on the wall of the pan.

Monitoring around Tank 16 after the overfill revealed no single point with high radioactivity but revealed many areas with low radioactivity. These areas were not localized in any section of the tank, but spread around the circumference of the tank. This would indicate that the existence of several leak areas, each associated with a few gallons of waste leakage, should be considered as the most plausible rationale of the leakage.

The source of the highest radioactivity detected was in the water addition system, which accounted for 7.0 curies of radioactivity - - the equivalent of a leak of approximately one gallon of waste. Since this radioactivity was observed almost immediately, it probably indicates the leak occurred in an area that channeled to the water addition system.

A total of 5.6 curies of radioactivity have been removed from the water addition system by pumping, and an estimated 0.8 curies moved from this system with the ground water flow primarily between 1962 and 1973. Estimates are that $\sim 0.6$ curies remain in this area from the initial leak. Figure 26 shows:

1) groupings of ground water radioactivity pumped from the system (from Figure 10) which are denoted by the data bars located at the average activity.

2) the normal ground water flow calculated for the periods when the system was not actively being pumped. This volume is shown by the spaces between data bars.

0.8 curies of radioactivity are calculated to have moved from the system with the ground water primarily between 1962 and 1973 . This estimate is based on the calculated volumes and using the concentrations obtained from the mean curve on Figure 26. (The flow velocity of ground water through this system was assumed to be $0.02 \mathrm{ft} / \mathrm{day}$.$) Inspection of Figure 26$ shows the ground water flow is small compared to that which had been pumped. 
The elution characteristics of typical ion exchange columns can be represented graphically, as shown in Figure 27. During the elution, the radioactivity would be expected to come off the ion exchange media more rapidly initially, then more slowly. If this rate of elution approaches a straight line on a semilog plot of ion concentration and elutriant volume, it is possible to calculate the heel of the ion remaining beyond the last point $\left(\mathrm{C}_{2}, \mathrm{~V}_{2}\right)$ by extrapolating the curve to infinity $(\infty)$. Mathematically this could be represented as

$$
\text { heel }=\int_{V_{2}}^{\infty} C d V
$$

If we integrate this formula we have

$$
\text { heel }=\frac{C_{2}\left(V_{1}-V_{2}\right)}{2.3 \log \left(C_{2} / C_{1}\right)} \text { or } \frac{C_{2}\left(V_{1}-V_{2}\right)}{\ln \left(C_{2} / C_{1}\right)}
$$

Using this equation the amount of radioactivity left in the soil is calculated to be 0.6 curie if the mean curve on Figure 26 is used. The values are 1.1 and 0.4 curies if the upper and lower curves are used.

No areas contaminated by a large volume of leakage were found in the investigation. A large amount of waste when diluted $\sim 100$-fold with ground water to $20.03 \mathrm{M} \mathrm{Na}^{+}$would disperse the clay particles and plug the soil, reducing flow $23700-$ fold. If the maximum leakage of 700 gallons of waste is assumed, $2230 \mathrm{ft}^{3}$ of soil would be required to contain the waste. If this waste ran along a channel (natural or one formed at the boundary of the tank or construction pad and soil), the soil contaminated by the 700 gallons of waste would be wedge shaped with the apex at the bottom. If this wedge ran 10 feet along a crack or channel it would be about 3 feet wide and 15 feet deep. The outer boundary of the wedge would be defined by the point at which the leading edge of the waste had become diluted to $0.03 \mathrm{M}$ and plugged the soil. There is little doubt that had this much soil been contaminated it would have been discovered during the subsequent monitoring.

This pluggage mechanism, which limits movement of waste through the soil from the area of leakage, would also tend to minimize leakage of waste into the soil if these leak areas occurred where the soil was saturated with water. The waste would then require containment in cavities resulting from tank construction. If this cavity were $1 / 2$ inch wide, the surface area would have to be $2200 \mathrm{ft}^{2}$ to contain the 700 gallons of leakage. This seems. like an unreasonably large cavity to have been left from tank construction. 


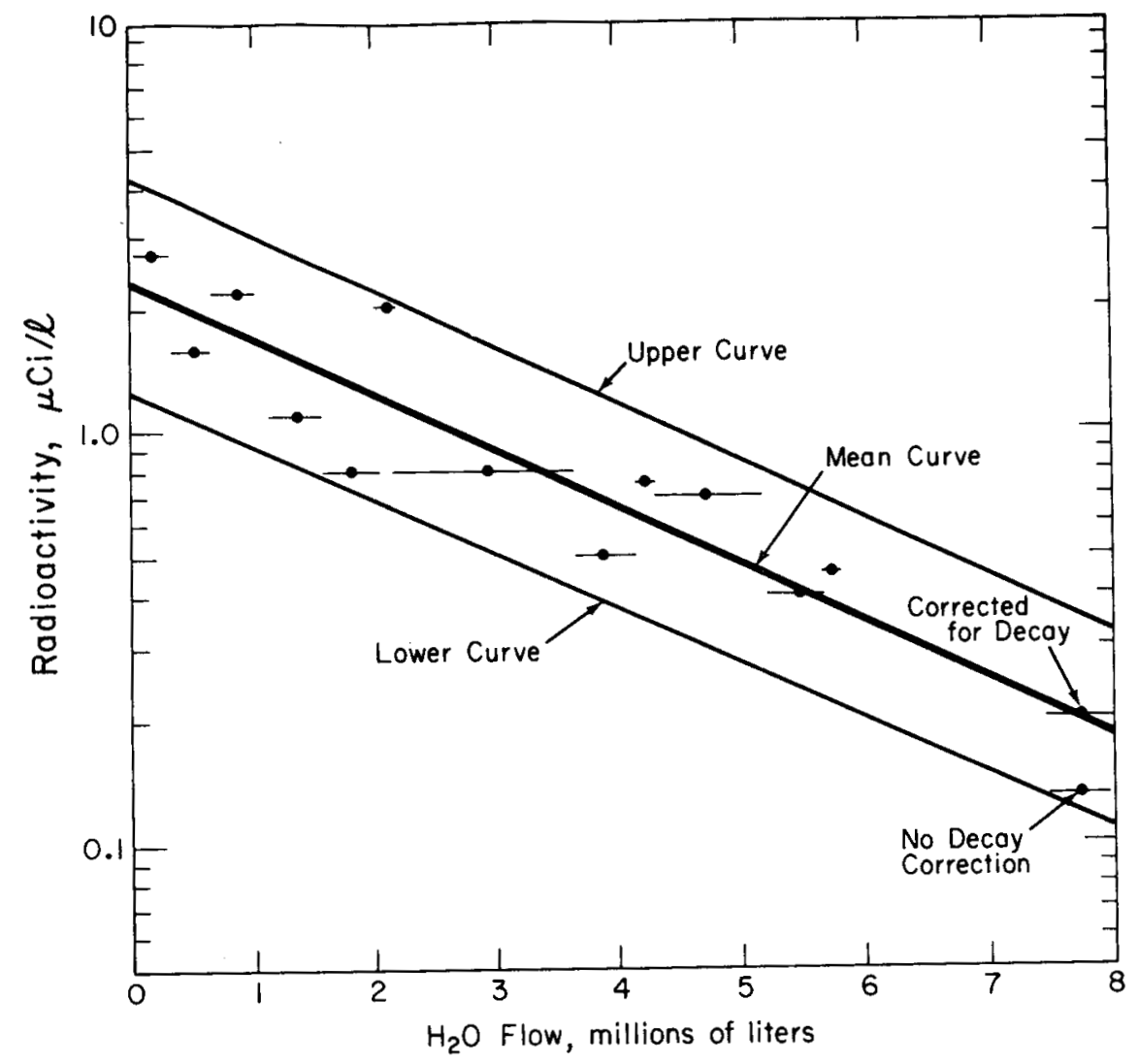

FIG. 26 RADIOACTIVITY REMOVED FROM WATER ADDITION SYSTEM

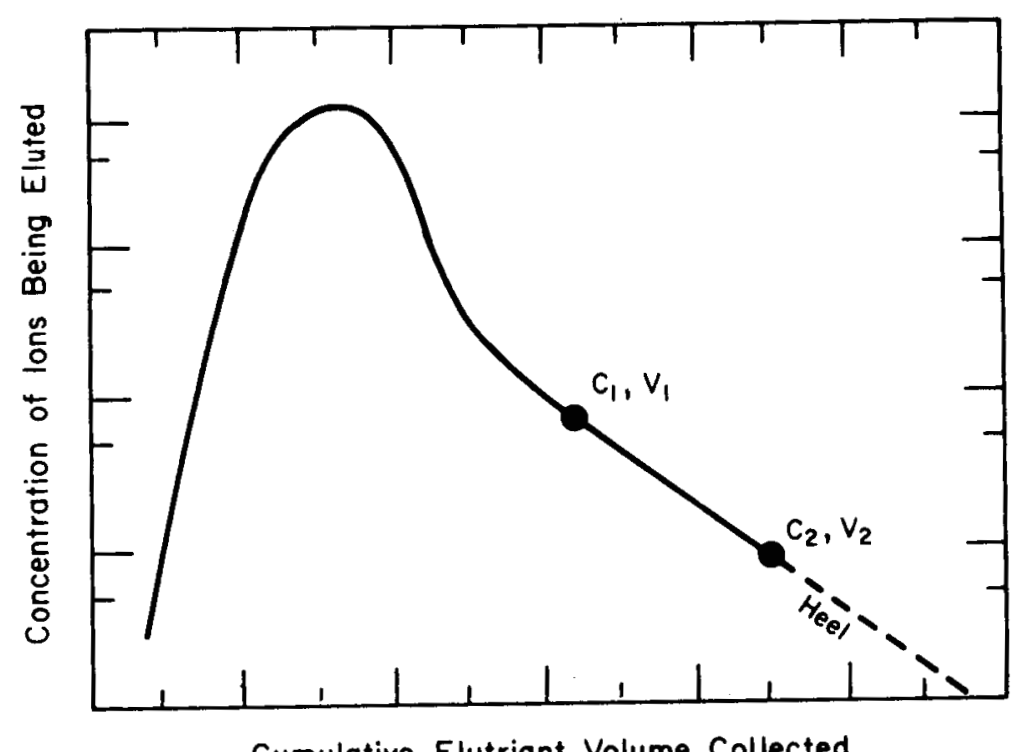

FIG. 27 ELUTION CHARACTERISTICS OF ION EXCHANGE MEDIA 
The calculated zow rate of radioactivity movement through the soil has been confirmed by monitoring experience. Based on known soil ion exchange characteristics and area hydrology, the leading edge (containing less than $0.2 \%$ of the cesium and strontium radioactivity) would be calculated to have moved approximately 0.1 foot in the 14 years since the annulus pan overfill. The center of the radioactivity would have traveled about 0.01 foot. If the radioactivity flowed through a zone with 10-100 times the permeability of the surrounding soil, the radioactivities would have moved less than 10 and 1 foot, respectively, for the leading edge and the center. In the 14 years that have elapsed since the annulus pan was overfilled, radioactivity has been discovered above and below the concrete construction pad near Tank 16 . This radioactivity located in these areas has been several hundred times the CG limit $\left(2 \times 10^{4}\right.$ $\mathrm{pCi} / 1)$. Ground water radioactivity within the tank area has decreased steadily since 1960. The radioactivity of the ground water 215 feet from the edge of the concrete construction pad has been fairly stable and well below the CG limit (between background and $100 \mathrm{pCi} / 1$ ). (One well 15 feet from the construction pad reached $1400 \mathrm{pCi} / 1$, apparently due to differences in permeability.) If one were to assume that the leakage had been mixed uniformly with water in the water addition system and was flowing at the expected rate and with an average concentration of $100 \mathrm{pCi} / 1$, between $2 \times 10^{-4}$ and $4 \times 10^{-4}$ curies of radioactivity would have moved more than 15 feet from the tank area.

In view of the low rate of radioactivity movement through the soil and the many areas of low radioactivity around the waste tank shortly after the annulus pan overfill, monitoring wells will not permit direct determination of the amount of radioactivity lost into the soil as a result of the Tank 16 annulus overfill. Monitoring does, however, substantiate other knowledge of radioactivity movement mechanisms. This total knowledge points out that the small loss of waste into the soil poses no threat to the public. 


\section{REFERENCES}

1. R. M. Girdler. Leaks in Radioactive-Waste Tanks. USAEC Report DP-990, E. I. du Pont de Nemours and Co., Savannah River Laboratory, Aiken, S. C. (1965).

2. WASH 1537. Environmental Statement: Waste Management Operation, Savannah River Plant, Aiken, South Carolina, to be issued.

3. WASH 1530. Environmental Statement: Additional High Level Waste Facilities. Savannah River Plant, Aiken, South Carolina, August 1974 .

4. WASH 1528. Environmental Statement: Status of High Level Waste Facilities, Savannah River Plant, Aiken, South Carolina, Apri 11973.

5. J. W. Fenimore. "Tracing Soil Moisture and Ground Water Flow at the Savannah River Plant." Conference Proceedings, Clems on University Council on Hydrology Conference CONF680309 , Hydrology in Water Resources Management, March 1968.

6. G. E. Siple. Geology and Ground Water of the Savannah River Plant and Vicinity, South Carolina. U. S. Geological Survey Water Supply Paper 1841. United States Government Printing Office, Washington, D. C. (1967).

7. S. 0. Reichert. "Geology Plays an Important Role in Radioactive Waste Management." Mining Engineering 20, No. 9, 98 (1968).

8. J. W. Fenimore and J. H. Horton. Influence of High Level Waste Salts on Movement of Strontium and Cesium in Savannah River Plant Soil. USAEC Report DP-1124, E. I. du Pont de Nemours and Co., Savannah River Laboratory, Aiken, S. C. (1968).

9. R. E. Grim. Clay Mineralogy. p 129, McGraw-Hill, New York (1953).

10. W. E. Prout. "Adsorption of Radioactive Wastes by Savannah River Plant Soil." Soil Science 86, 13 (1958). 
11. E. A. Simpson. "A Summary of Current Geological Research in the USA Pertinent to Radioactive Waste Disposal on Land." U. S. Geological Survey, Washington, D. C., in Disposal of Radioactive Wastes, Conference Proceedings, Monaco, November 16-21, 1959, Vo1. II, pp 517-531.

12. G. de Josselin de Jong. "Dispersion in Flow through Porous Media." Division of Hydraulic and Sanitary Engineering, University of California, Berkeley, Ground Disposal of Radioactive Wastes, Conference Proceedings TID-7621, Berkeley, California, August 25-27, 1959, pp 123-130.

13. W. E. Prout. Adsorption of Fission Products by Savannah River Soizs. USAEC Report DP-394, E. I. du Pont de Nemours and Co., Savannah River Laboratory, Aiken, S. C. (1959).

14. P. J. Parsons. Movement of Radioactive Waste Through Soiz. Report No. AECL-1325, Chalk River, Canada (1961). 


\section{APPENDIX A}

\section{CHRONOLOGY OF TANK 16 LEAKAGE AND DETECTION}

Waste.

May 29, 1959. Tank 16 received first transfer of High Activity

October 1959. Almost continuous difficulty with liquid in annulus was experienced. The leak detection system (a conductivity alarm located in the bottom of the annular space) was almost constantly in the alarm condition. Routine visual inspections of the annulus were undertaken. Trouble was thought to be rainwater inleakage. Rainwater was detected leaking through sealing compound used to seal access port plug. No waste was observed below the inspection access port.

November 5, 1959. Dampness was observed beneath both the south and north annulus access ports.

November 15, 1959. Radioactive liquid was found in the annulus beneath the north access port (a swab dipped in the solution read $12 \mathrm{R} / \mathrm{hr}$ at 3 inches). No significant radioactivity was detected beneath other access ports. White solid material was observed protruding from the side of the tank beneath the south annulus access port. Operation of the dehumidification system was stopped. An auxiliary blower was installed to purge the vapor space above the liquid waste of gaseous radiolytic decomposition products that might concentrate in this vapor space.

November 19, 1959. The white protrusions under the south annulus access port appeared to have increased in size. The access port plug was removed, and a sample of the white material was obtained. A $0.038-\mathrm{g}$ portion of the sample partially dissolved in $30 \mathrm{ml}$ of water resulted in a solution of $\mathrm{pH} \mathrm{10.6.} \mathrm{The} \mathrm{analysis}$ of the solution indicated the original sample radioactivity to be $4.3 \times 10^{6} \alpha \mathrm{d} /(\mathrm{min})(\mathrm{g}), 1.9 \times 10^{7} \beta \mathrm{c} /(\mathrm{min})(\mathrm{g})$, and $9.3 \times 10^{6}$ $\gamma \mathrm{c} /(\mathrm{min})(\mathrm{g})$.

November 20, 1959. Mirrors and a telescope were arranged for viewing leaks"beneath the south annulus access port. Seven separate salt protuberances were observed along the horizontal weld 30 inches above the bottom of the tank. Attempts to photograph the leaks using the mirrors were partially successful. 
November 30, 1959. Attempts to obtain clear photographs of the leaks using the mirrors were unsuccessful, and were discontinued. (Figure $A-1$ is representative of the best of these photographs.) Inspection using a TV camera was begun.

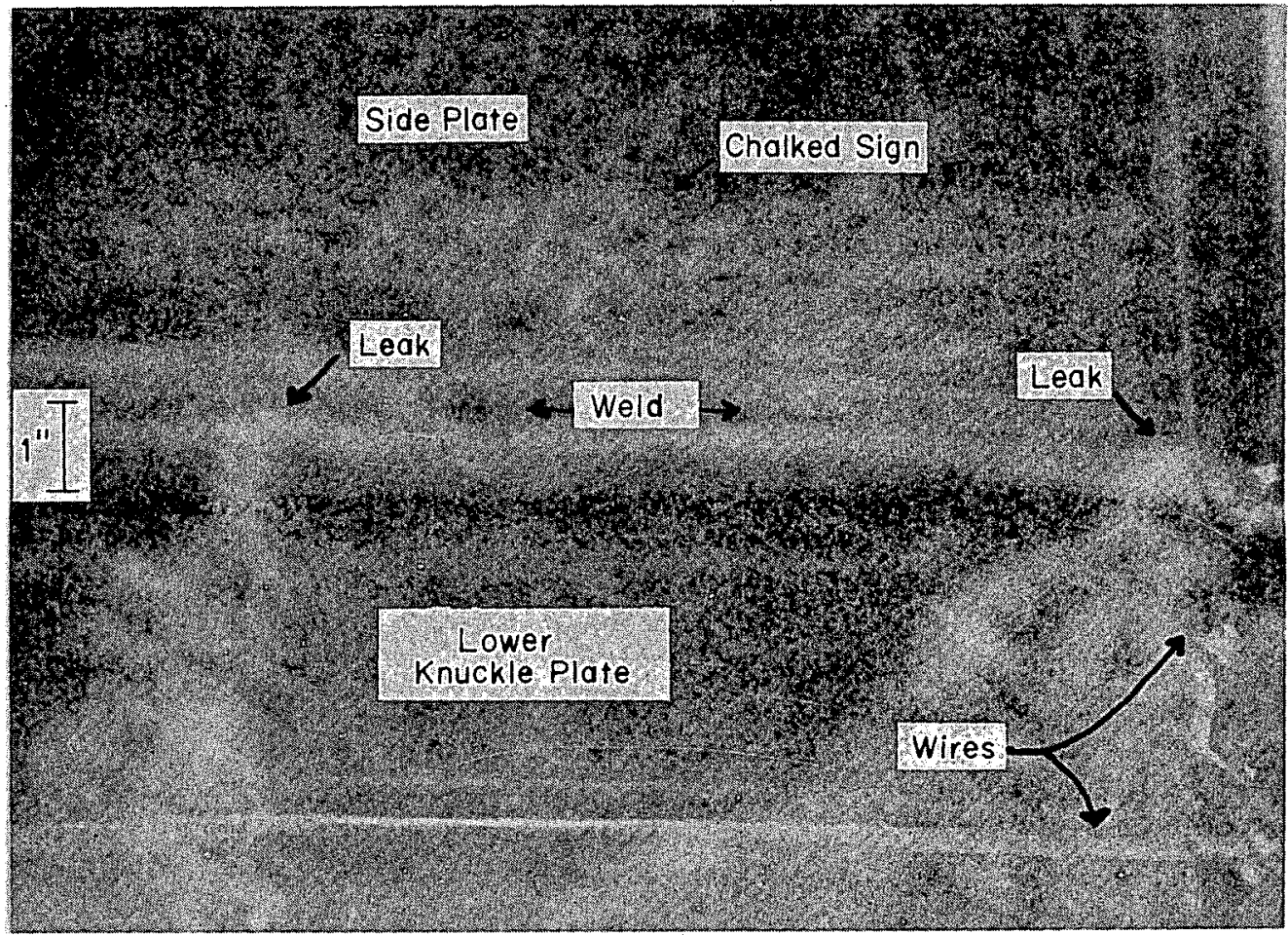

FIG. A-1 PHOTOGRAPH OF INITIAL LEAKAGE - TANK 16

December 4, 1959. The entire area beneath the south annulus access port was inspected using the mirrors and telescope. Five areas of suspected leakage were observed at the lower knuckle plate weld.

December 10, 1959. Radiation and temperature profiles indicated that the sludge zone was about 6 to 9 inches in height (the small amount of radioactive waste in the annulus was not thought to affect the radiation profile). The 6 to 9 inch sludge level indicated the sodium aluminate was still in solution and the sludge had only attained $\sim 1 / 3$ of its expected level. For this amount of waste, the sludge was expected to be about $1-1 / 2$ to 2 feet deep, and supernate radiation about $1 / 3$ of the observed values. 
January 5, 1960. A routine visual inspection of the annulus was made. No changes were noted.

February 11, 1960. A television camera was lowered into the annulus. Photographs of the monitor screen were taken (see Figure A-2). Comparing these pictures with construction $x$-rays of welds, the leakage appeared to occur at patched areas in seam welds between lower knuckle and side wall plates. The x-rays indicated that the weld had been satisfactorily repaired. A reproduction of the construction $x$-ray for the region photographed is shown in Figure A-3.

The project was discontinued because of mechanical difficulties with the television equipment. Negotiations were started for purchase of an improved television system for further viewing.

February 17, 1960. A routine visual inspection of the annulus revealed no change.

Apriz 7, 1960. A routine visual inspection of the annulus through the north annulus access port revealed:

- Liquid on the floor of the annulus pan. The wet area was $\sim 2$ $\mathrm{ft}^{2}$. This area had been dry since November 1959.

- White solids protruding from the side of the tank at about the elevation of the lower knuckle plate weld (30 inches from the bottom of the tank). This white protuberance was quite similar in appearance to that observed under the south annulus access port.

Apriz 18, 1960. A routine visual inspection of the annulus indicated no significant change beneath the north access port.

Apriz 28, 1960. The condition beneath the north annulus access port was essentially unchanged. The liquid was less than $1 / 2$ inch deep (conductivity alarm wires located on the pan floor were visible above the surface).

May 19, 1960. Tank 16 was filled to design capacity, 303 inches, and high activity waste was diverted to Tank 14 . 


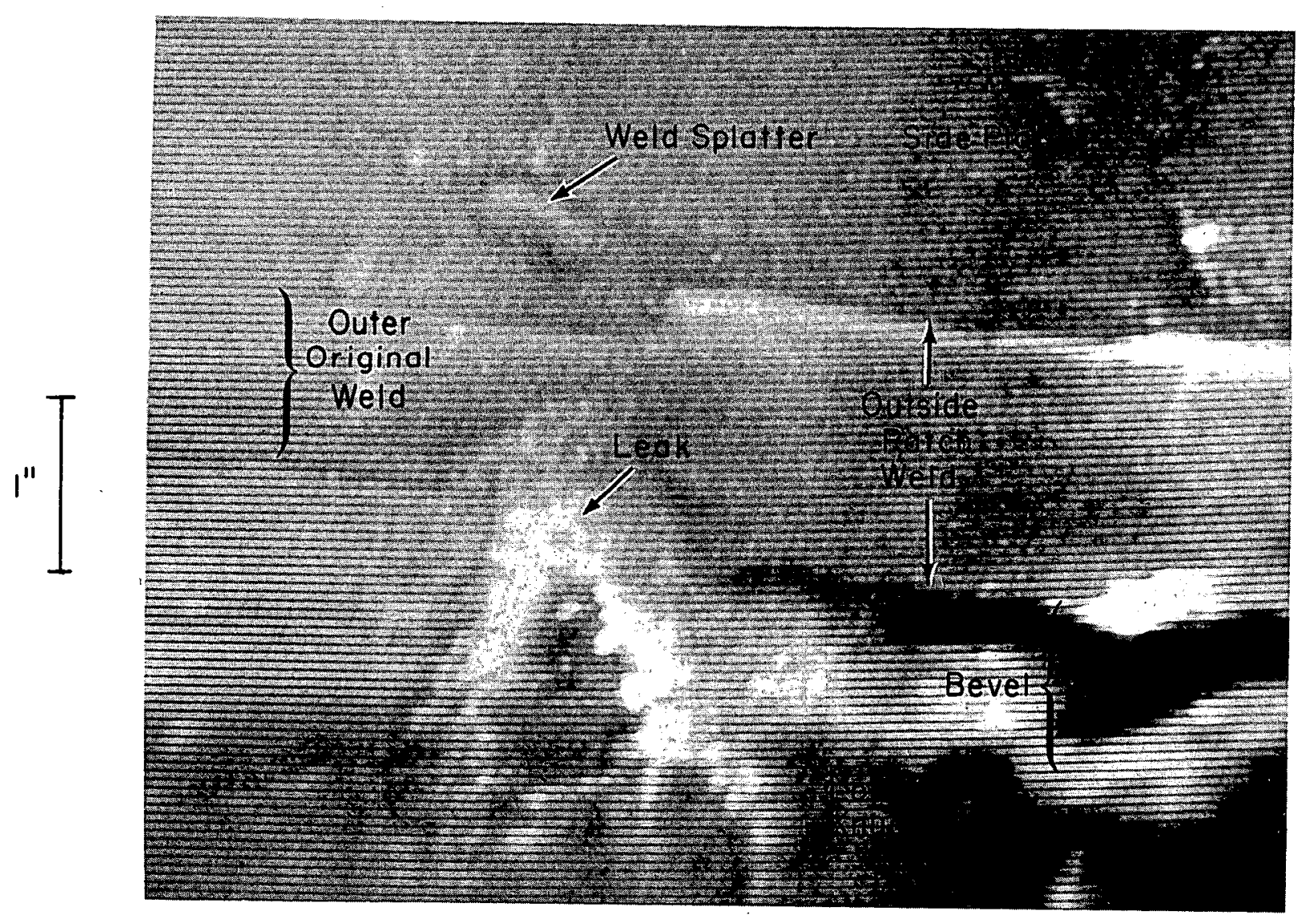

FIG. A-2 TV IMAGE OF INITIAL LEAKAGE - TANK 16 


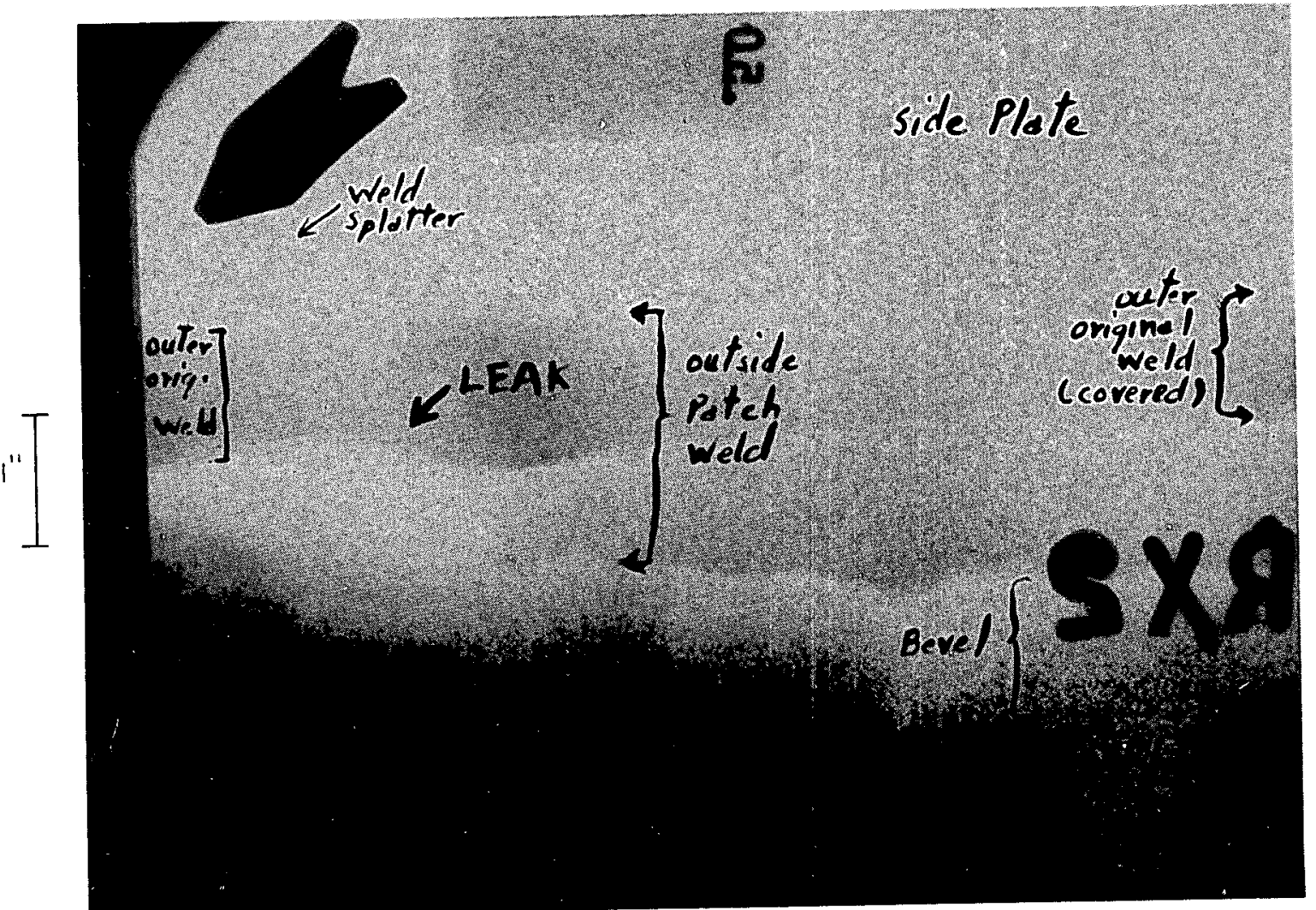

FIG. A-3 CONSTRUCTION WELD X-RAY OF POINT OF INITIAL LEAKAGE TANK 16 
May 25, 1960. Tank 16 sludge and supernatant samples were taken See Table A-1 for analytical results of these samples. Work on sludge samples obtained from Purex high level waste tanks at about the same time indicated that representative sludge samples may be difficult to obtain.

TABLE $A-1$

\section{ANALYSES OF WASTE FROM TANK 16}

\begin{tabular}{|c|c|c|c|}
\hline & $\begin{array}{l}\text { Annulus } \\
9 / 17 / 00\end{array}$ & $\begin{array}{c}\text { Tank Supernatan } \\
\text { Solution } \\
5 / 25 / 00 \\
\end{array}$ & $\begin{array}{c}\text { Tank Sludge } \\
5 / 25 / 60 \\
\end{array}$ \\
\hline $\mathrm{pH}$ & $>11$ & $>11$ & $>11$ \\
\hline Specific Gravity & 1.36 & 1.37 & $a$ \\
\hline Solid Content, wt $\%$ & 42.0 & 45.8 & 50.3 \\
\hline $\mathrm{OH}^{-}, \mathrm{g} / \mathrm{l}$ & $b$ & 64.8 & 300 \\
\hline $\mathrm{CO}_{3}=\mathrm{g} / \mathrm{l}$ & $b$ & None Detected & None Detected \\
\hline $\mathrm{HCO}_{3}{ }^{-}, \mathrm{g} / \mathrm{l}$ & $b$ & None Detected & None Detected \\
\hline Gross Alpha, d/(min) (m1) & $5.2 \times 10^{3}$ & $7.6 \times 10^{3}$ & $3.4 \times 10^{4 c}$ \\
\hline $\mathrm{Pu}, \mathrm{d} /(\min )(\mathrm{ml})$ & $b$ & $8.7 \times 10^{3}$ & $3.2 \times 10^{4 c}$ \\
\hline $\mathrm{Am}-\mathrm{Cm}, \mathrm{d} /(\mathrm{min})(\mathrm{ml})$ & $b$ & $<2.5 \times 10^{3}$ & $500^{c}$ \\
\hline $\mathrm{Np}, \mathrm{d} /(\min )(\mathrm{m} 1)$ & $b$ & 22 & $16.6^{c}$ \\
\hline Gross Beta, d/(min) (m1) & $3.7 \times 10^{9}$ & $2.8 \times 10^{9}$ & $4.4 \times 10^{9 d}$ \\
\hline Ce, $d /(\min )(m 1)$ & $b$ & $1.9 \times 10^{6}$ & $8.0 \times 10^{3 d}$ \\
\hline $\mathrm{Sr}, \mathrm{d} /(\mathrm{min})(\mathrm{ml})$ & $b$ & $7.7 \times 10^{7}$ & $2.2 \times 10^{7 d}$ \\
\hline $\mathrm{TRE}^{e} \mathrm{~d} /(\min )(\mathrm{m} 1)$ & $b$ & $5.3 \times 10^{7}$ & $3.5 \times 10^{8 d}$ \\
\hline Gross Gamma, d/(min) (m1) & $4.6 \times 10^{9}$ & $4.2 \times 10^{9}$ & $5.0 \times 10^{7 d}$ \\
\hline $\mathrm{Zr}-\mathrm{Nb}, \mathrm{d} /(\min )(\mathrm{ml})$ & $b$ & $3.8 \times 10^{8}$ & $2.6 \times 10^{7 d}$ \\
\hline $\mathrm{Cs}, \mathrm{d} /(\mathrm{min})(\mathrm{ml})$ & $b$ & $3.7 \times 10^{9}$ & $1.8 \times 10^{7 d}$ \\
\hline $\mathrm{Ru}, \mathrm{d} /(\min )(\mathrm{ml})$ & $b$ & $2.2 \times 10^{9}$ & $1.4 \times 10^{7 d}$ \\
\hline $\mathrm{U}, \mathrm{g} / \mathrm{l}$ & $b$ & $2.4 \times 10^{-3}$ & $1.1 \times 10^{-3} f$ \\
\hline $\mathrm{Al}, \mathrm{g} / \mathrm{l}$ & $b$ & 25.5 & $b$ \\
\hline $\mathrm{Cl}, \mathrm{g} / \mathrm{l}$ & $b$ & 0.6 & $a$ \\
\hline
\end{tabular}

a. Not analyzed due to high viscosity of sample.

b. Not determined.

c. Results reported in d/(min) (mg).

d. Results reported in $\mathrm{d} /(\mathrm{min})(\mathrm{mg})$.

$e$. Total Rare Earths plus $\mathrm{UX}_{1}$.

f. Result reported in $\mathrm{mg} / \mathrm{mg}$. 
August 1, 1960. A visual inspection of the annulus under the north access port showed that all surfaces were dripping wet. No crystals were visible either on the side of the tank or on the bottom of the annulus. The conductivity alarm wires were visible through the waste which covered them.

August 2, 1960. The high liquid level probes, installed to take the place of the conductivity alarm, were checked, adjusted, and repositioned in the annulus. The voltage was set so that the alarm from these probes was deenergized in the humid atmosphere but would come on if the probe were lowered into the liquid waste. The probes were rewired so that the alarm would be energized by probe-to-ground conduction rather than conduction between the two probe contacts.

August 12, 1960. The dehumidification system was modified to purge the annulus and tank in series and restarted. The change was made to remove the condensation observed in the annulus on the inspection of August 1. Considerable difficulty was encountered in sealing the small annulus access port plugs against the 1 -inch $\mathrm{H}_{2} \mathrm{O}$ pressure developed by the blower. Unsealed plugs leaked contaminated water vapor from the tank.

August 19, 1960. A visual inspection of the annulus beneath the north access port was made. Surfaces of the tank appeared much drier than on August 1. The liquid appeared turbid rather than clear. White crystals on top of the liquid were again visible. The liquid level was apparently about the same as on the previous inspection. Conductivity alarm wires could not be seen due to the turbidity of the solution and the presence of crystals. The dehumidification system was functioning well and evaporating water from the annulus.

August 21, 1960. The dehumidification system was turned off because of contamination from air leaks around the annulus access port plugs. The radiation at this time had increased from a background reading of $\sim 2,000 \mathrm{c} / \mathrm{min}$ on August 12 to $30,000 \mathrm{c} / \mathrm{min}$ on August 19. The air escaping from the forced dehumidification system contained $30 \times$ CG of fission products.

August 25, 1960. The dehumidification system was turned on for 8 hours to purge the gas space of the tank.

August 30, 1960. The dehumidifier was operated 7 hours again to purge the gas space of the tank.

September 1; 1960. A temperature profile of the tank contents was made. Results were similar to those measured on December 10 , 1959 and indicated the sludge layer had still not completely settled. 
September 7, 1960. A visual inspection of the annulus revealed that the liquid level in the annular space surrounding Tank 16 was much higher than on previous inspections. It was rodded and found to be 4-1/2 feet deep. Gross leakage from the tank into the annulus (in excess of $1-1 / 2$ gallons/minute) had developed during the previous several weeks. The high liquid level probes did not provide the intended function of notification of a significant change in level in the annulus.

Fabrication of a jet assembly for transferring the liquid from the annulus of Tank 16 to Tank 14 was undertaken immediately on an emergency basis. Before the jet could be installed and the transfer started, the liquid level in the annulus reached, and, on September 8 exceeded the top of the steel annulus pan. The volume of waste exceeding the top of the annulus pan for about 6 hours was estimated to be 700 gallons. Figure A-4 shows the time when the annulus pan was overfilled. Table A-1 gives the analyses of a sample from the annulus and shows the solution to be waste.

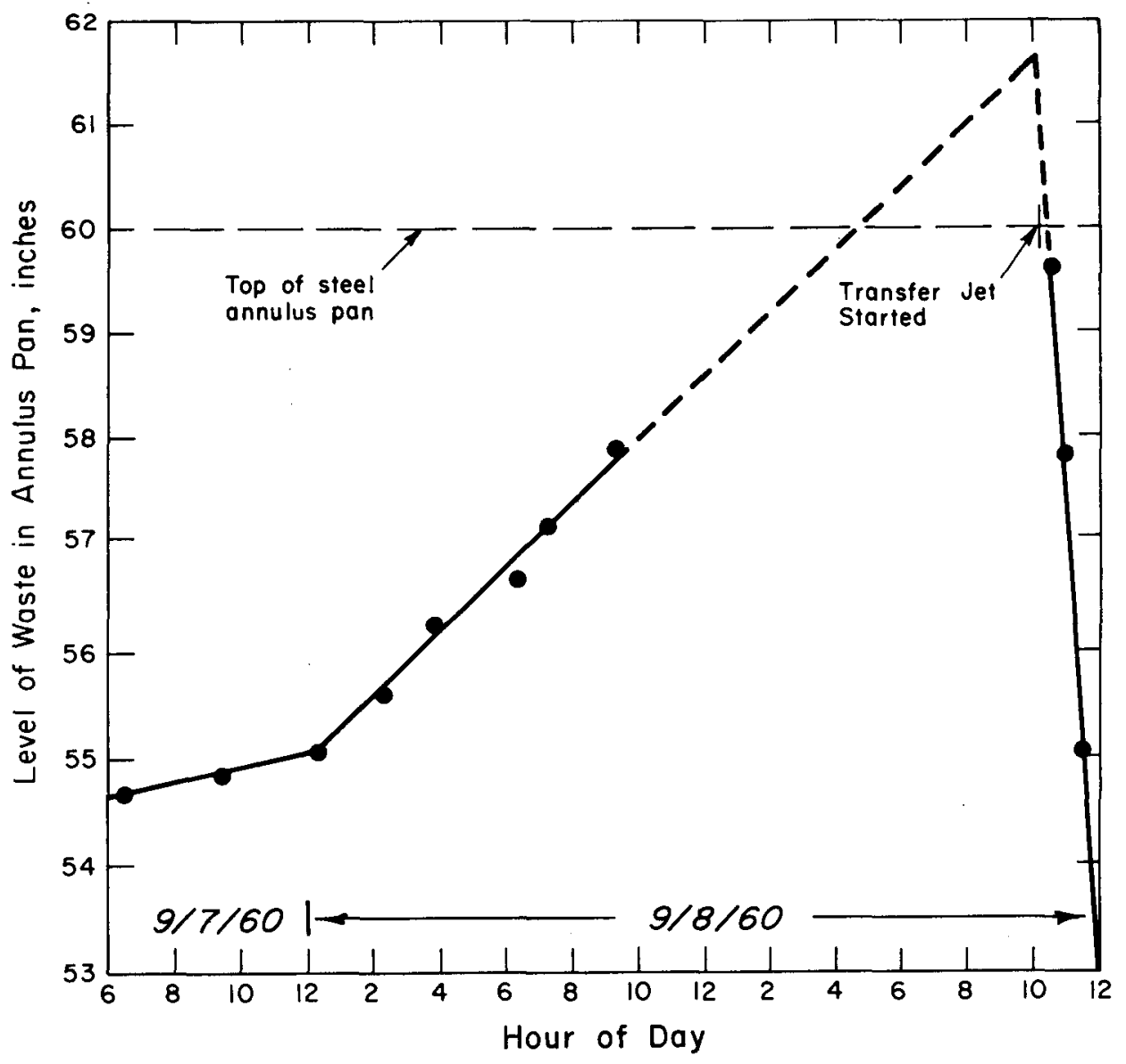

FIG. A-4 WASTE LEVEL IN TANK 16 ANNULUS 
September 11 to October 15, 1960. Periodic operation of the annulus jet assembly kept the waste level in the annulus below the top of the steel annulus pan (Figure A-5) after the initial overflow. The rate of leakage continued to increase until the level in the tank decreased to the horizontal weld between the top knuckle plate and side plate. This continued increase in the rate of leakage indicated that the size or number of the fault or faults on the upper knuckle plate weld continued to increase. When the waste inside the tank decreased to the upper knuckle plate weld, the leak rate decreased to $3.5 \mathrm{gallons} / \mathrm{min}$ and appeared to level out at that rate (see Detail 1 of Figure A-6). About 185,000 gallons of waste leaked from the tank into the annulus pan and was transferred to Tank 14.

October 12, 1960. A jet was installed in Tank 16, and part of the contents of Tank 16 was transferred to Tank 15 starting on October 12. Approximately 350,000 gallons was transferred by October 15. During the period of the transfer from Tank 16 to Tank 15 the rate of leakage from Tank 16 into the annulus appeared to decrease stepwise. This pattern in the leakage rate indicated that three major areas of leakage existed below the large leak at the upper knuckle plate weld, at about the 223-inch, 192-inch, and 160-inch levels (Detail 2 of Figure A-6).

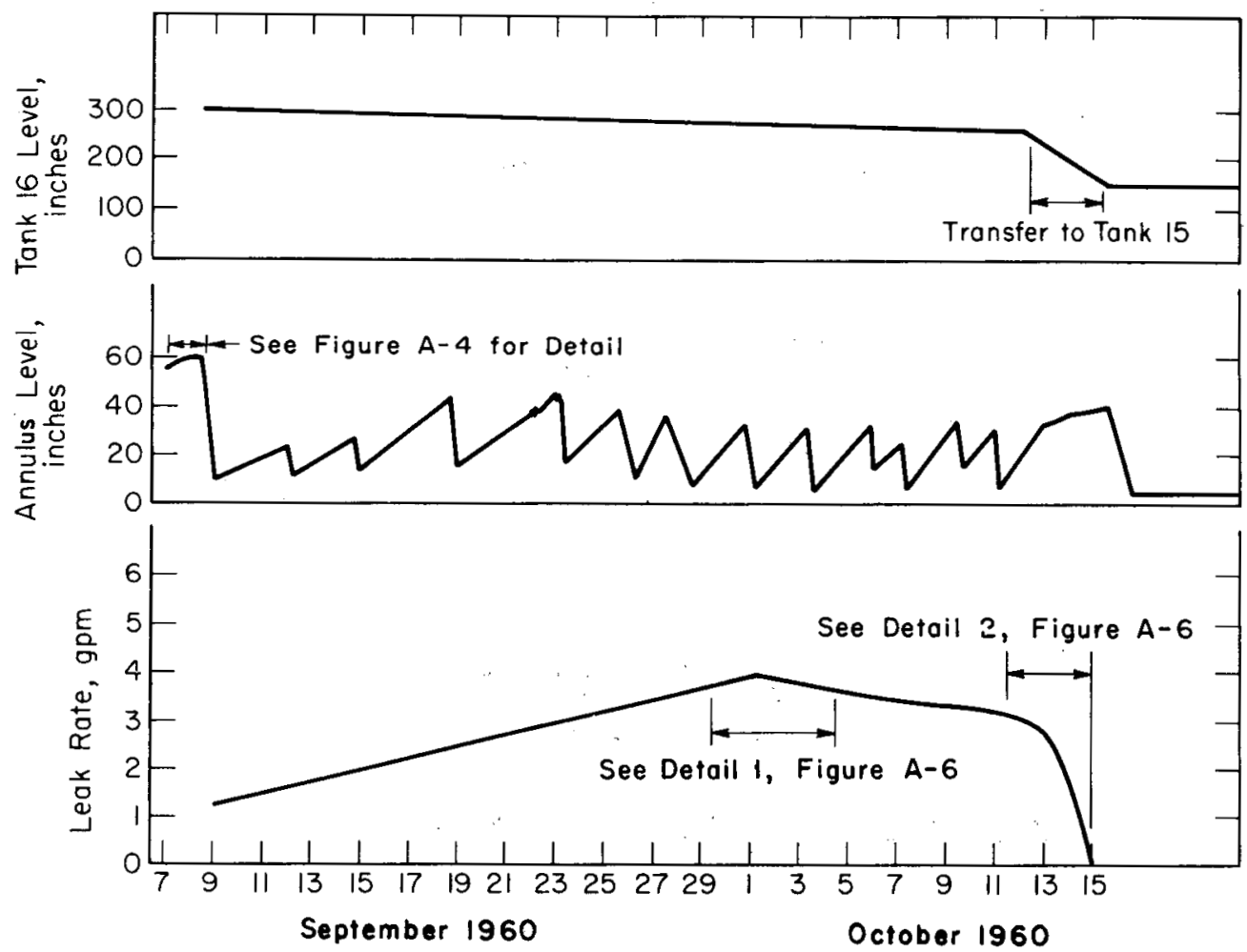

FIG. A-5 WASTE TANK 16 LEAKAGE 

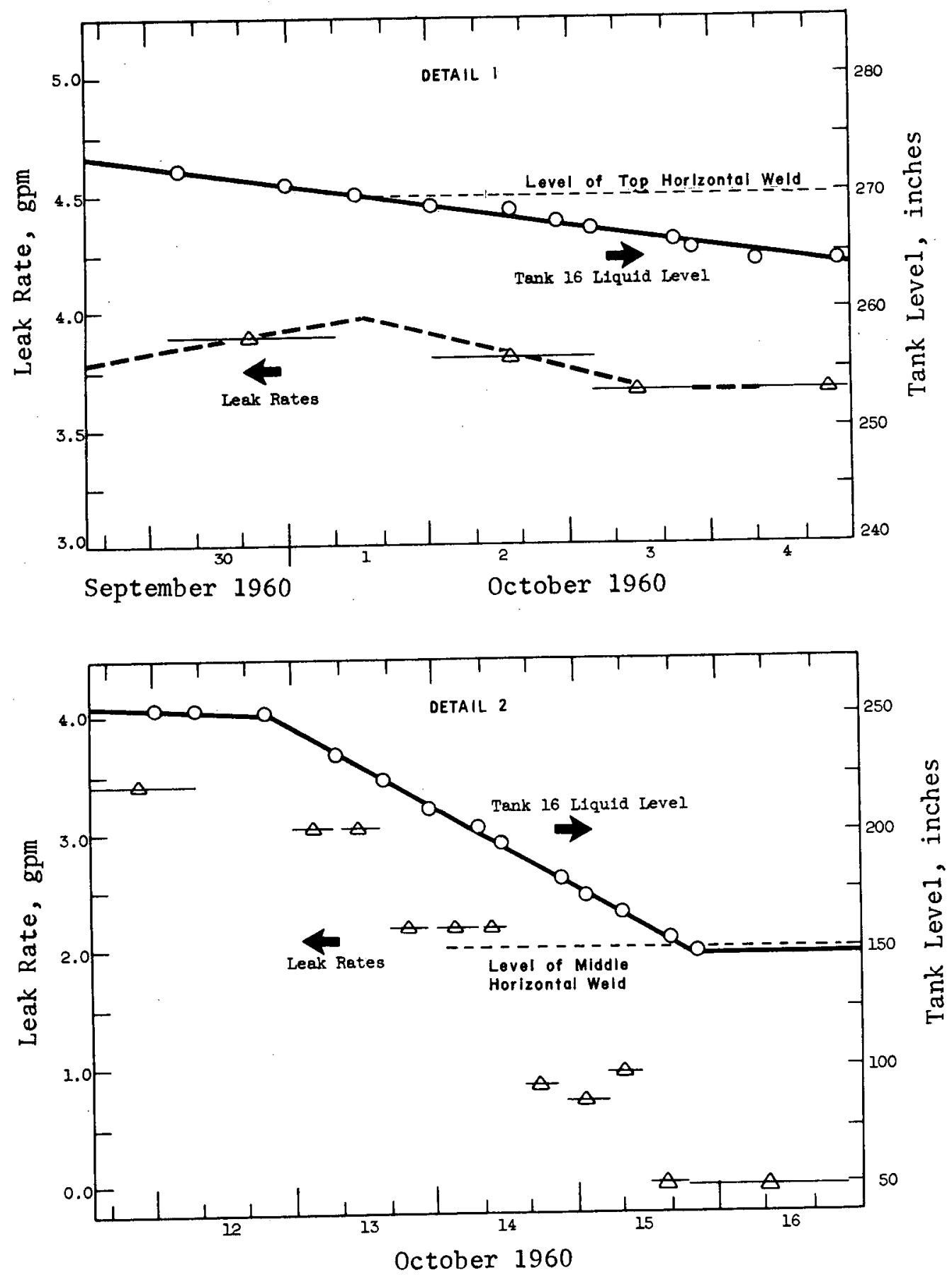

FIG. A-6 WASTE TANK 16 LEAKAGE DETAILS 
Leakage from Tank 16 apparently stopped when the level in the tank was lowered to a point just above the center horizontal weld, and the transfer to Tank 15 was discontinued at a tank level of 147 inches which is slightly below the center horizontal weld.

September 1960. Immediately following the overfill of the pan, a search was begun for radioactivity in the ground surrounding the tank. Samples of ground water were obtained from four wells ( 1 , 2,3 , and 4 in Figure A-7) which had been installed during the construction of the tanks and extended to a depth of 12 feet below the concrete construction pad. These samples contained no radioactivity immediately after the overfill of the annulus pan. Static water levels in these wells indicate a gradient sloping to the NW of only $0.06 \%$. With such a small gradient, ground water flow was very slow. Wells 2 and 3 were sampled for several years and these results are discussed in Appendix B, Extended Monitoring Program.

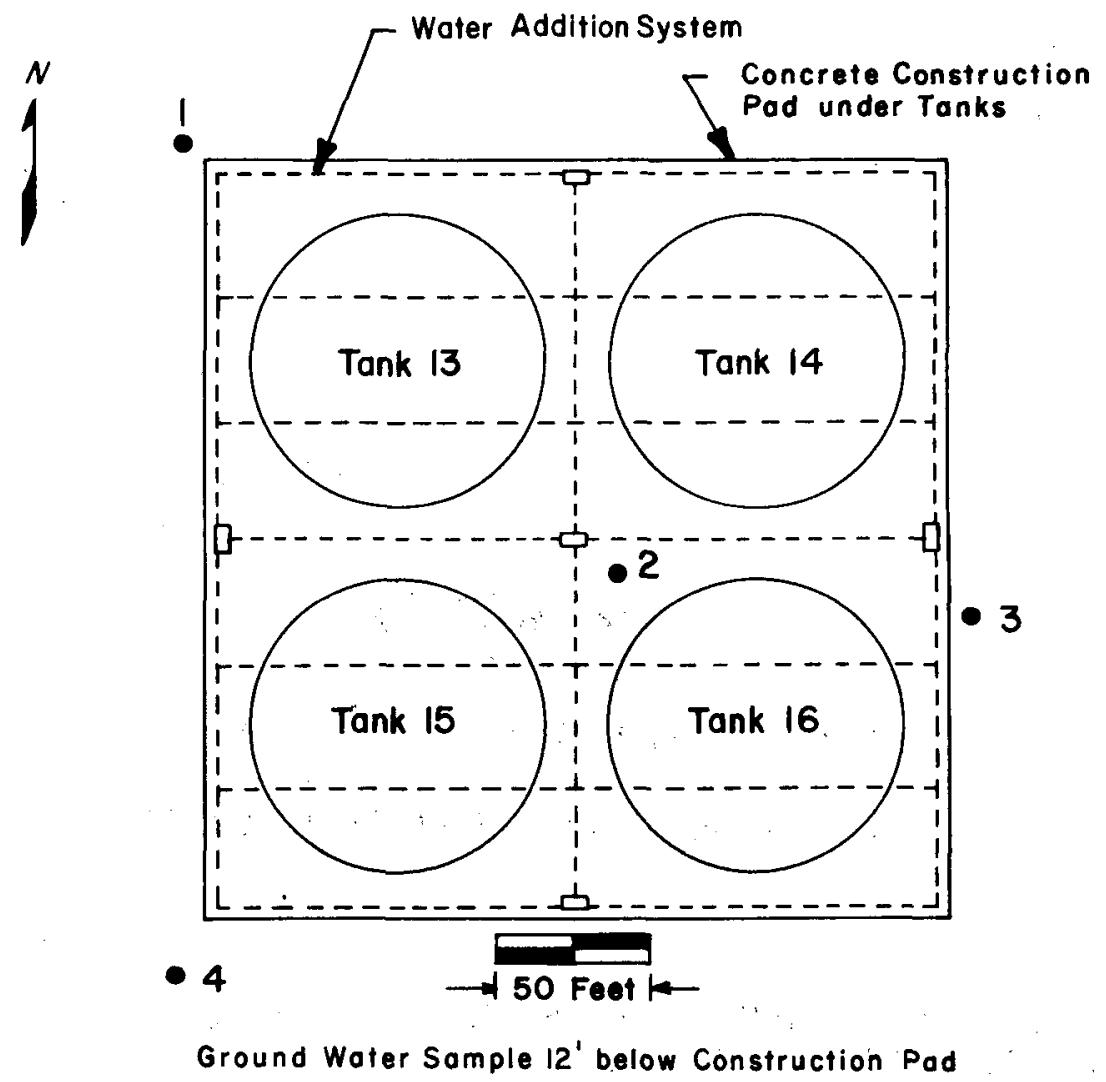

FIG. A-7 EXISTING GROUND WATER MONITORING WELLS 
September 19 to September 21, 1960. Four wells were installed 5 feet from Tank 16 encasement. These wells were drilled to the depth of the concrete construction pad. Location of the wells can be seen on Figure A-8.

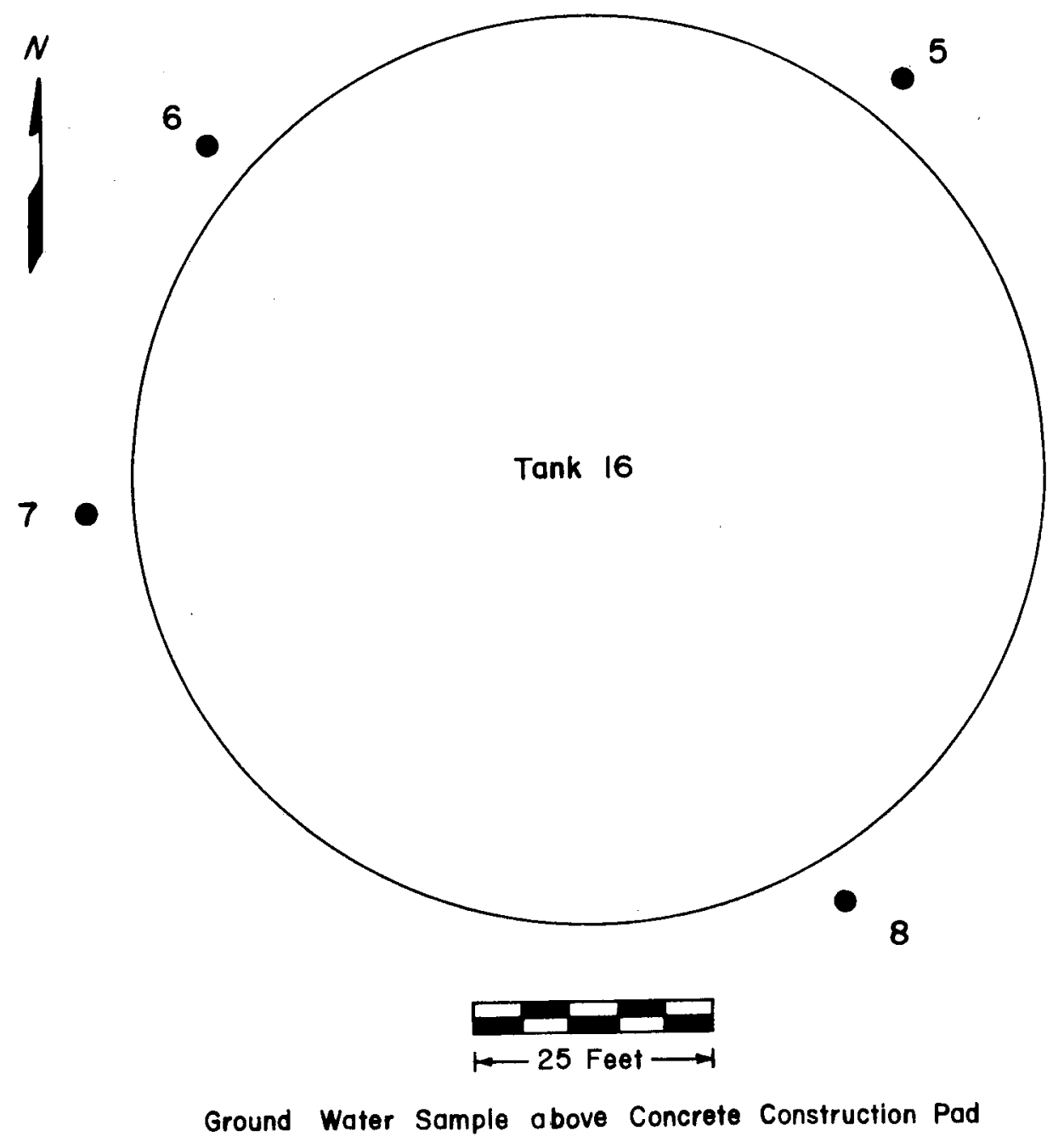

FIG. A-8 WELLS FIVE FEET FROM TANK 16

September 23, 1960 to March 26, 1961. Well 6 was selected as the well from which to pump a large sample of ground water since the water table sloped in that direction at the time. Water was pumped from that well at 1.26 liters per minute $(0.33$ gallon per 
minute) from September 23, 1960 to March 26, 1961, and sampled daily. Daily samples were also taken from Wells 5,7 , and 8 , and all were analyzed for nonvolatile beta.* After pumping from Well 6 for 11 days (or 25,300 gallons), radioactivity appeared in the water and increased rapidly, as shown in Figure A-9. The peak concentration of $750,000 \mathrm{pCi} / 1$ iter was reached on November 27, 1960. The concentrations in Wells 5, 7, and 8 fluctuated between 20 and $200 \mathrm{pCi} / \ell$, during this time only slightly above background of 5-15 $\mathrm{pCi} / \ell$. The radioactivity was identified as primarily $134,13^{7} \mathrm{Cs}$. No strontium could be detected. (NOTE: The other radionuclides of the waste shown on Table A-1 could have been masked by the cesium radioactivity).

The ratio of ${ }^{137} \mathrm{Cs}$ to ${ }^{134} \mathrm{Cs}$ in the water was 8 to 1 . Calculations of the ${ }^{137} \mathrm{Cs}$ to ${ }^{134} \mathrm{Cs}$ ratio based on reactor data of the waste in each tank almost positively identified the radioactivity as having come from Tank 16. The ratios of ${ }^{137} \mathrm{Cs}$ to ${ }^{134} \mathrm{Cs}$ calculated for waste in Tanks 13 and 14 were more than 20 to 1 , but that calculated for Tank 16 waste was 9 to 1 . Water pumped from Well 6 contained a total of $0.06 \mathrm{Ci}$. Pumping and sampling of water from Well 6 were abandoned near the end of March because more radioactivity had been found under the concrete construction pad in the water addition system than in Well 6. Sampling of We1ls 5, 7, and 8 is continuing and results are discussed in Appendix B, Extended Monitoring Program.

October 13 to October 21, 1960. After radioactivity was detected in Well 6, twenty-one temporary wells (Wells 9 through 29 in Figure $A-10$ ) were drilled to the concrete pad around the circumference of Tank 16 encasement, one foot from the encasement and at about 13-foot intervals. Drill cuttings were monitored continuously with portable survey instruments, and water samples were collected and analyzed for radioactivity. Gamma radiation levels in each well were determined with a gamma scintillation probe inserted into the we11. Gamma radiation from the waste tank overshadowed any reading from radioactivity in the drilled wells. Portable survey instruments detected no significant radioactivity in the drill cuttings. Contaminated damp proofing material was removed from two wells on the south side of the tank. This material from Wells 14 and 19 radiated $1 \mathrm{mrad} / \mathrm{hr}$ and $150 \mathrm{mrad} / \mathrm{hr}$ at 2 inches, respectively. The ground water from these two wells plus that from several others contained low levels of radioactivity. These wells and their radioactivity levels are listed in Table A-2. These temporary wells were sampled, then backfilled and abandoned.

*Nonvolatile beta analysis was used to determined the radioactivity of ground water unless otherwise noted. This general purpose analysis measures both beta and gamma radioactivities of the samples. Calibration for this analysis was established using Radium D \& E standards. 


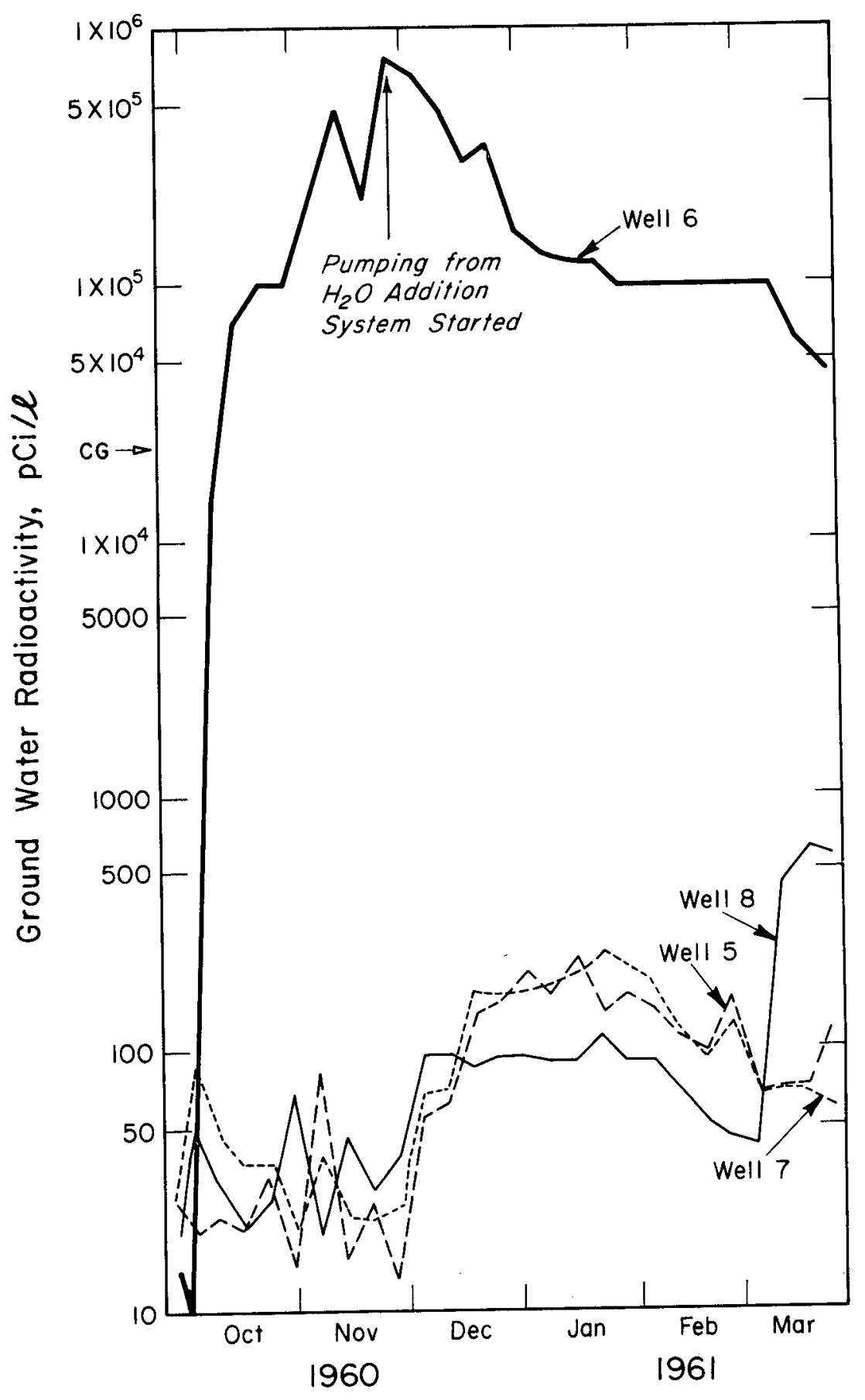

FIG. A-9 GROUND WATER RADIOACTIVITY 


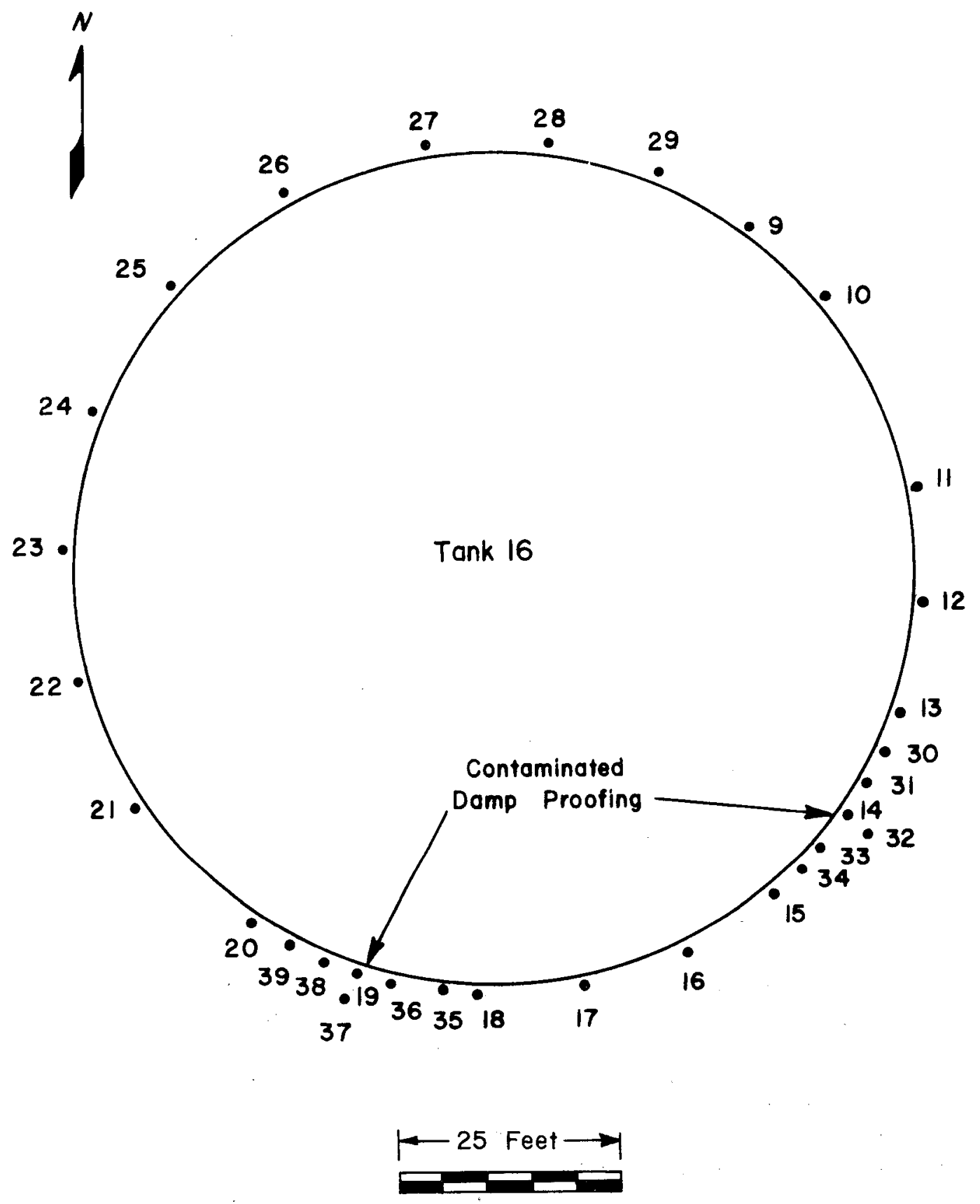

Ground Water Sample above Concrete Construction Pad

FIG. A-10 CIRCUMFERENTIAL WELLS SURROUNDING TANK 16 
TABLE A-2

RADIOACTIVITY OF GROUND WATER

ONE FOOT FROM TANK 16

\begin{tabular}{cc}
$\begin{array}{c}\text { Wel1 } \\
\text { Nuslber }\end{array}$ & $\begin{array}{c}\text { Ground Water Radioactivity, } \\
\text { pCi/liter }\end{array}$ \\
\cline { 1 - 2 } 10 & 2,000 \\
11 & 700 \\
13 & 1,200 \\
14 & $18,000^{a}$ \\
16 & 3,000 \\
19 & $60,000^{b}$ \\
21 & 1,800 \\
Background & $5-15$ \\
a. Identified as $144 \mathrm{Ce}$, the source \\
of which could not be determined. \\
b. Identified as 134,137 Cs.
\end{tabular}

October 22 to October 23, 1960. Ten additional wells (We11s 30 through 39, Figure A-10) were drilled at 4-foot intervals on either side of Wells 14 and 19 . These wells contained no significant radioactivity, and were backfilled and abandoned.

October 27 to November 17, 1960. To locate the flow path of radioactivity to Well 6 , nine additional temporary wells (Wells 40 through 48 in Figure A-11) were installed. Radioactivity of 8800 pCi/liter was found in Well 48. The other eight wells contained only low or background levels of radioactivity. These wells were backfilled and abandoned also. The radioactivity appeared to enter We11 6 in a narrow band.

November 29, 1960 to May 4, 1961. To measure the radioactivity below the concrete construction pad directly below Tanks 13, 14, 15, and 16, water was pumped from the water addition system below these tanks and the construction pad. (Figure A-12 shows the layout of the water addition system.) Ground water was pumped at an average rate of 11.4 liters/min (4300 gallons/day) from Riser 2 and returned to the water addition system through Riser 3 and sampled daily for radioactivity. Radioactivity was discovered immediately, as seen in Figure A-13, at concentration 210 times that found above the construction pad. 


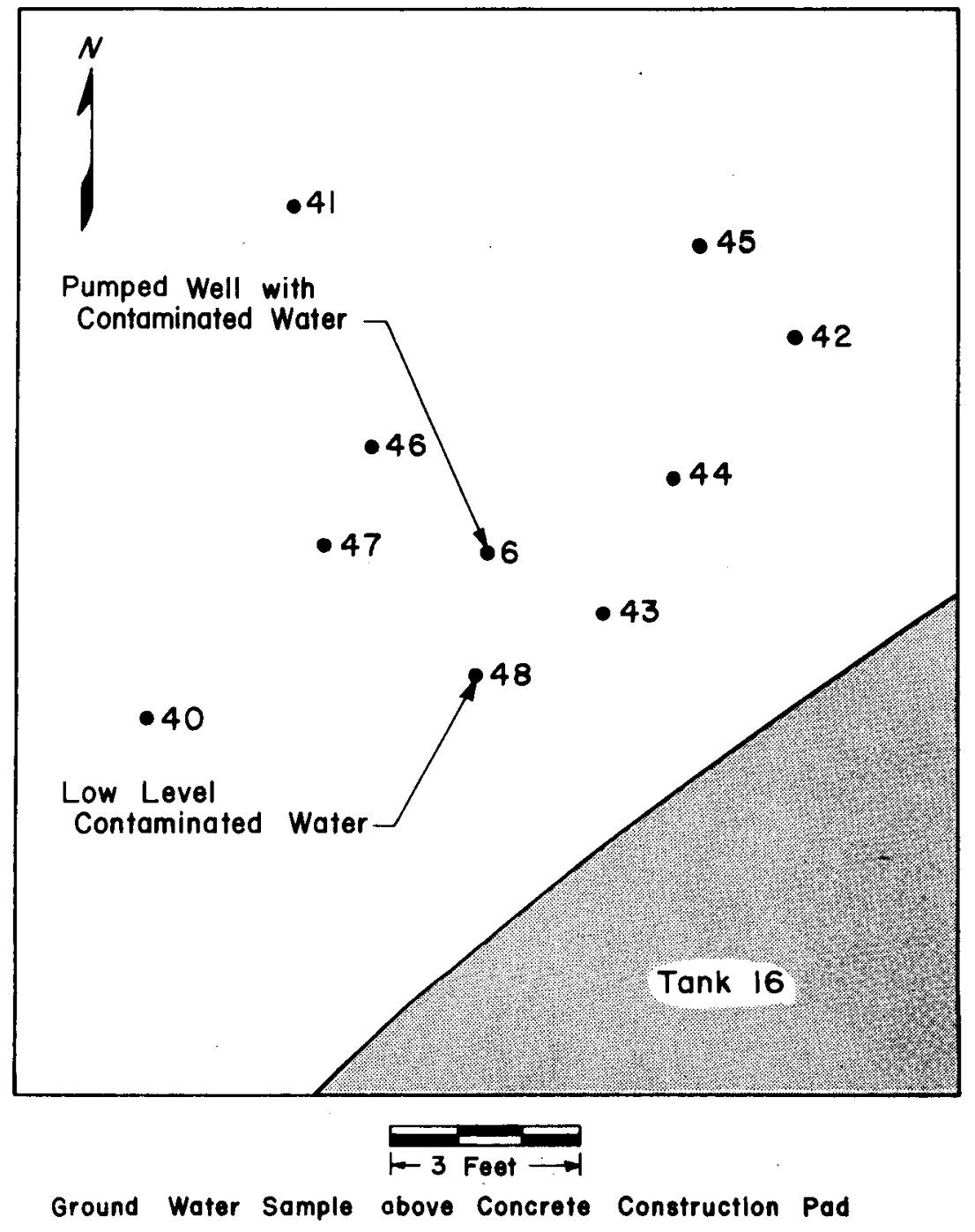

FIG. A-11 WELLS TO DETERMINE LEAK PATH TO WELL 6 


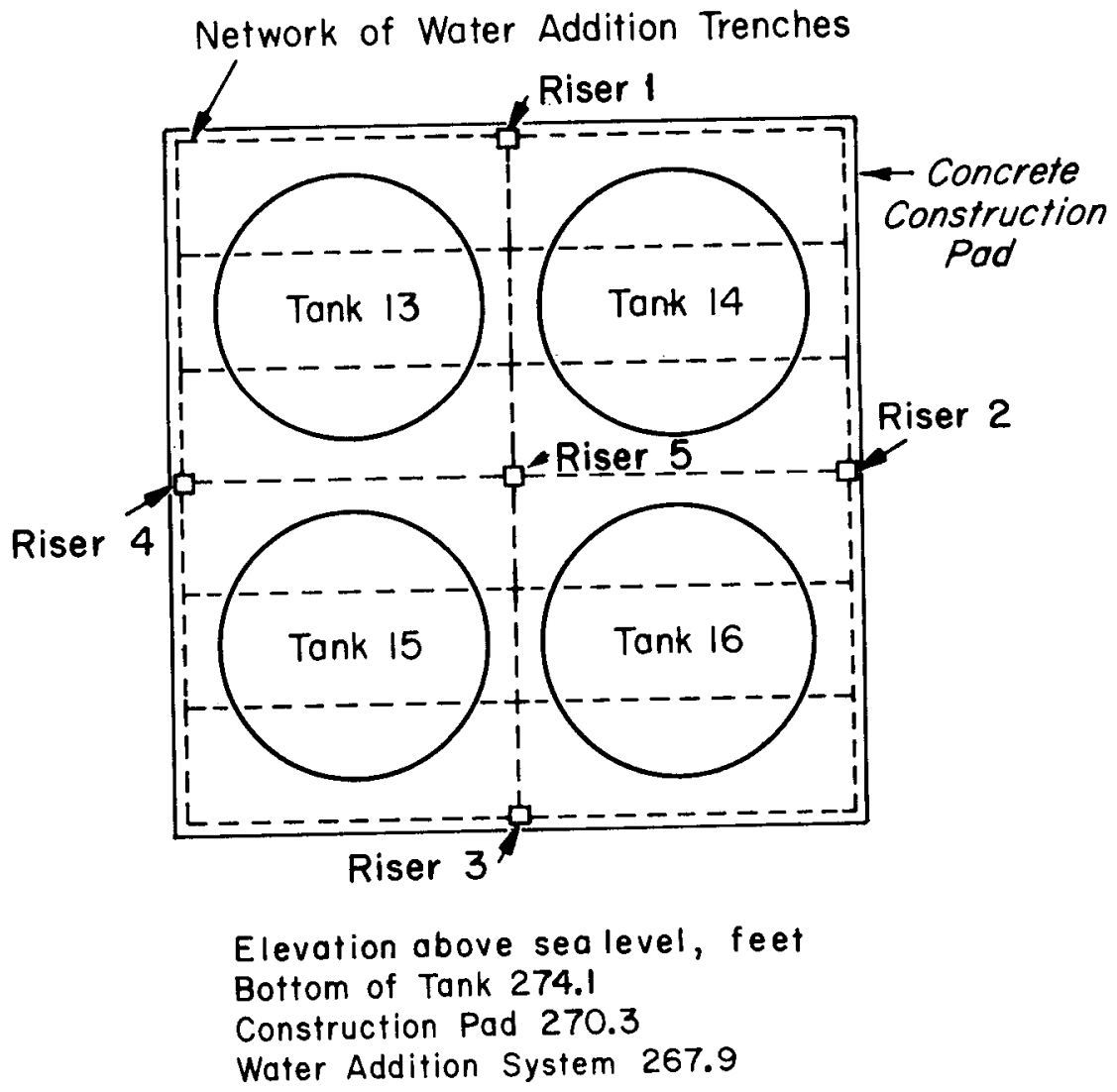

FIG. A-12 WATER ADDITION SYSTEM UNDER TANKS 13, 14, 15, AND 16 

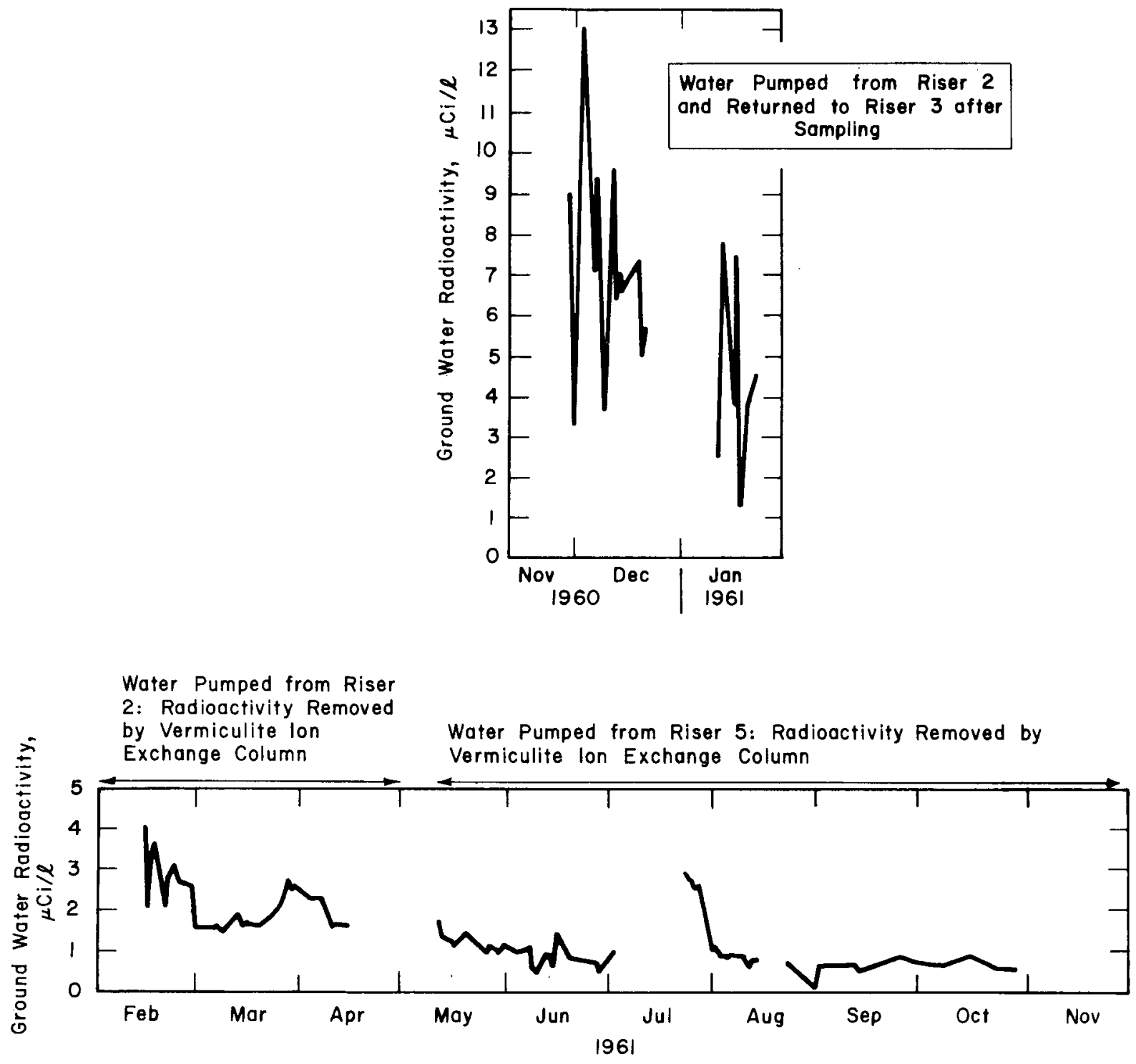

Woter Pumped from Woter Addition System Not Returned

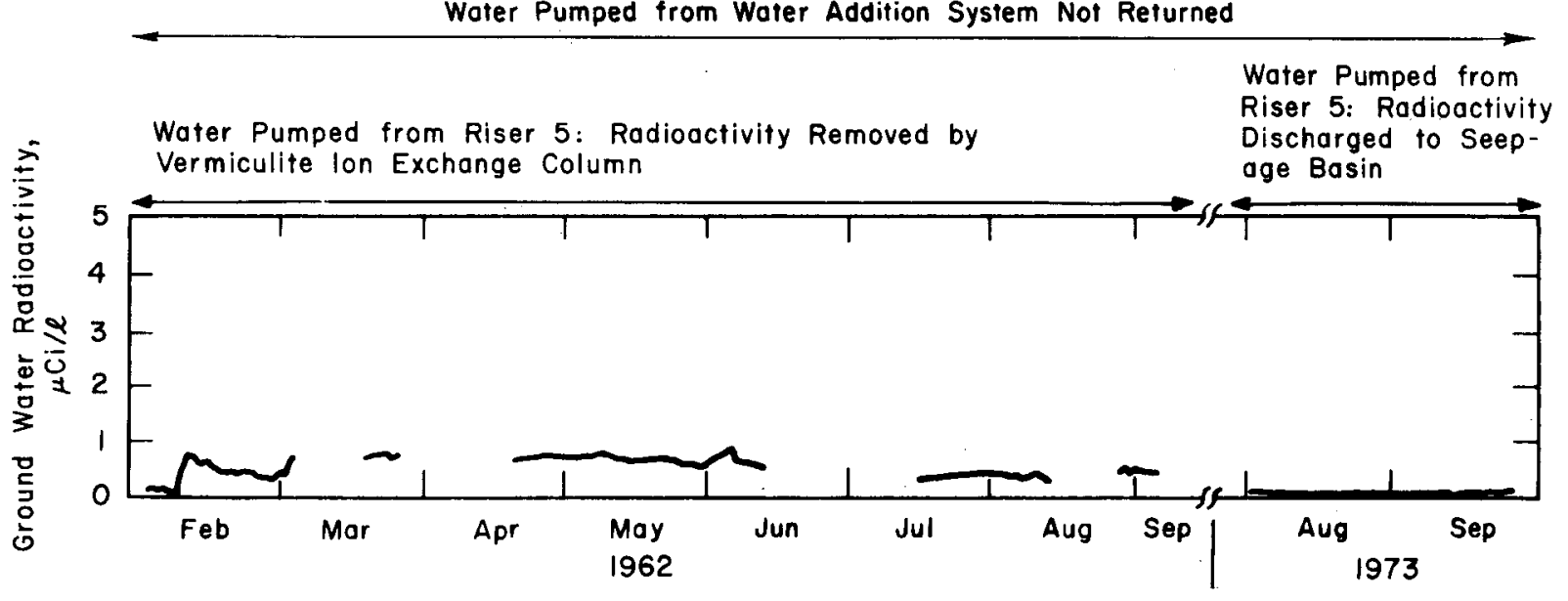

FIG. A-13 RADIOACTIVITY REMOVED FROM WATER ADDITION SYSTEM 
Pulse height analyses of water pumped from the water addition system during December 1960 and of water from Well 6 showed the radioactivity was almost. entirely ${ }^{134,137} \mathrm{Cs}$. The ${ }^{137} \mathrm{Cs}$ to ${ }^{134} \mathrm{Cs}$ ratio was also 8 to 1 , indicating that the radioactivity came from Tank 16. The water addition system had been sampled in March 1960 before the Tank 16 annulus overfill, and the maximum concentration at that time was $18 \mathrm{pCi} / 1$, which is essentially at background.

December 2 to December 15, 1960. To detect horizontal movement of radioactivity from the tank area, twelve permanent wells (We11s 49-60) were installed. Most were located about 15 feet from the edge of the concrete construction pad and screened 10 feet below the construction pad. Locations of these wells are shown in Figure A-14. The water from these wells was at or near background initially. The results of the long range sampling program can be found in Appen$\operatorname{dix}$ B, Extended Monitoring Program.

January 4, 1961. In a visual inspection, the annulus appeared dry. The waste left in the annulus from the previous transfer had crystallized.

February, 1961. The walls of Tank 16 were systematically examined, using a closed circuit television camera suspended below the annulus access ports. The first area that was inspected was the wall beneath the south annulus access port. A total of 19 "suspected" or "probable" leaks were observed in this series of observations, which covered 8 to $10 \%$ of the tank wall. The leaks were generally on or near the horizontal welds, as seen on Figure A-15. Three leaks located on the side wall plates did not appear to be associated with any weld. Appendix D covers the tank wall inspections, metallurgical studies, and sampling program to establish the cause of leakage.

February 4 to August 14, 1961. An ion exchange colum filled with vermiculite to remove cesium radioactivity from the water was installed in the Riser 2 pump discharge of the water addition system. Water from this pump was then diverted to the seepage basin. Previously the water containing the radionuclides was recirculated to the water addition system. The radioactivity removed from the water addition system during the period is shown on Figure A-13.

October 1961 to March 1962. Two 5-3/4-inch-diameter samples were cut from the Tank 16 wall straddling the top horizontal seam weld. Cracks in the samples were judged by metallurgists to have been caused by stress corrosion. 


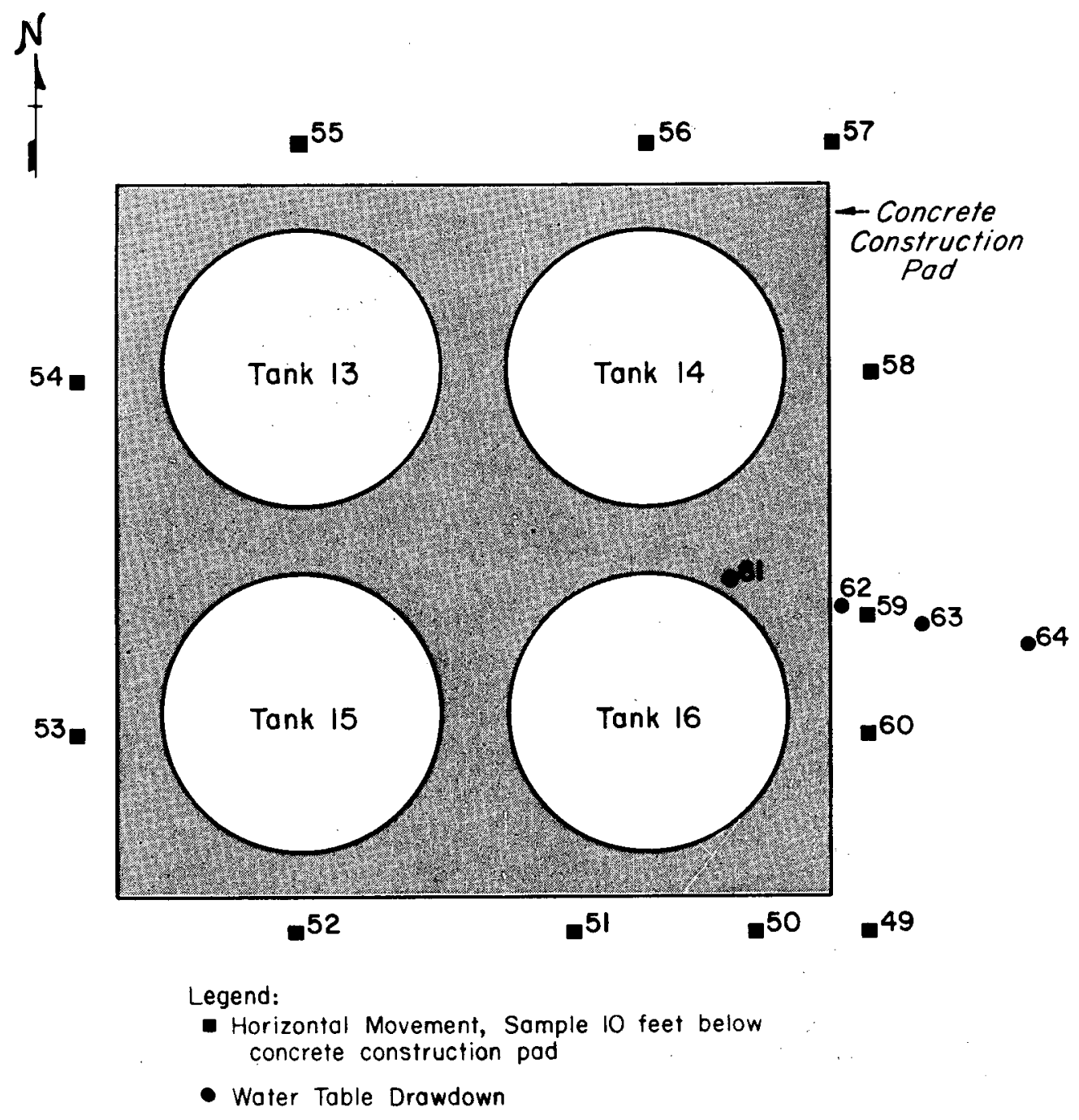

FIG. A-14 WELLS TO DETERMINE HORIZONTAL MOVEMENT AND WATER TABLE. DRAWDOWN 


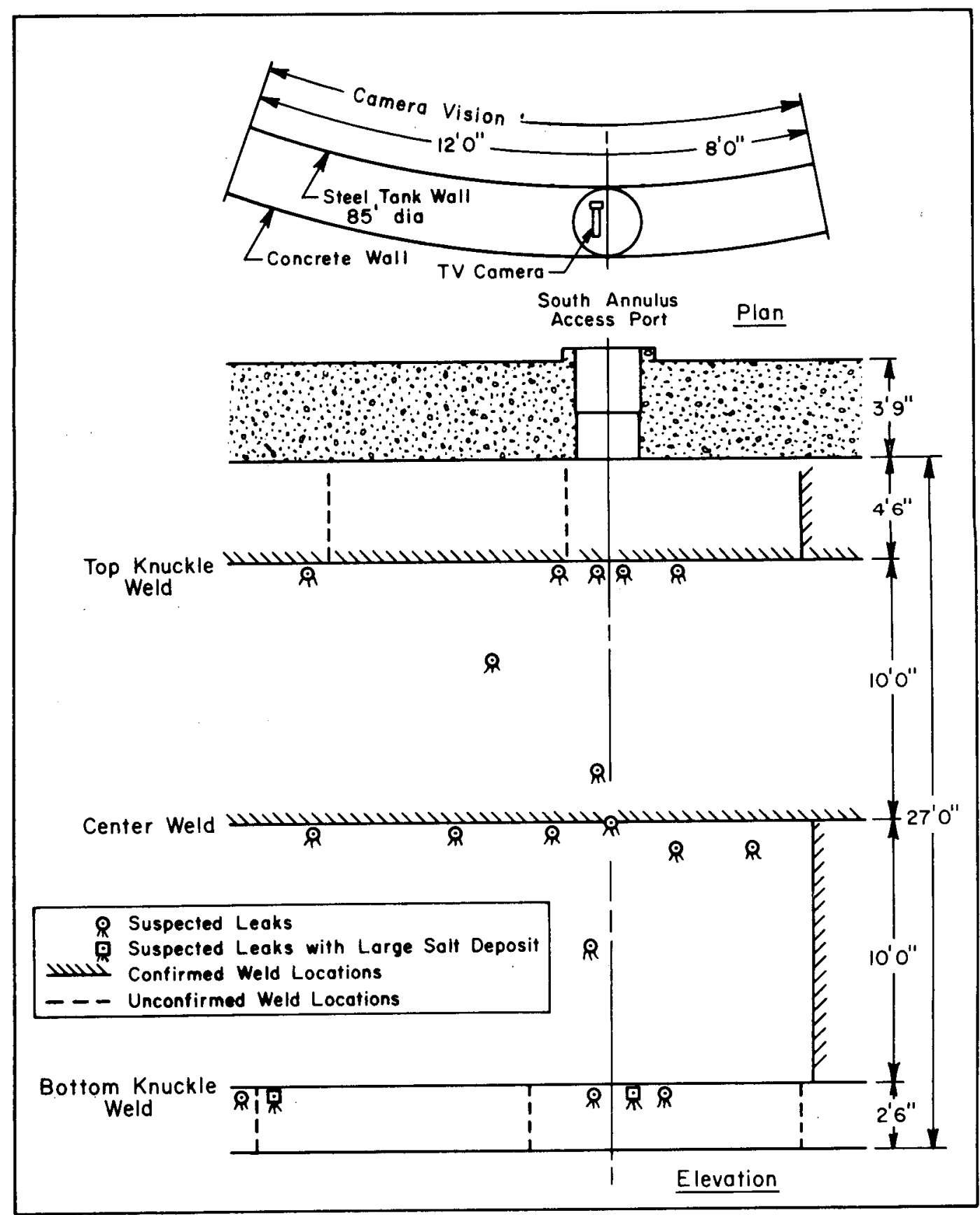

FIG. A-15 LEAK AREAS BELOW SOUTH ANNULUS ACCESS PORT OF TANK 16 FEBRUARY 1961 
May 11, 1961 to November 1, 1963. Water was pumped intermittently from Riser 5 to the seepage basins at a rate of 11.4 liters/min. Vermiculite ion exchange columns continued to be used to remove cesium activity from the water before the water was discarded.

A cone of depression, created by pumping ground water from the water addition system, caused ground water flow into the water addition system from all directions. This inflow of water prevented migration of radionuclides from the area surrounding Waste Tank 16. To measure the extent of the water table depression, four additional we11s $(61,62,63$, and 64 shown in Figure A-14) were installed. Intermittent pumping demonstrated both drawdown and recovery of the water table. Results of this study are presented in Appendix F, Reversal of Ground Water Gradient.

September 11, 1964 to Apriz 14, 1965. Since no significant radioactivity was found in the soil surrounding Waste Tank 16 for several years following the annulus overfill, an investigation was undertaken to determine if radioactivity had migrated down in the soil beneath the tank. The specific gravities of ground water and waste supernate were 1.0 and 1.36 , respectively.

In percolating downward, the waste would probably disperse because of stratification of the underlying soil. Therefore, wells drilled around the concrete encasement and to a depth of about 100 feet below the bottom of the tank should intercept soil through which the waste moved as it flowed downward. Between September 1964 and April 1965, fifteen wells were drilled around the tank to depths of 70 to 120 feet below the concrete pad (We11s 65 to $76,78,80$, and 81 in Figure A-16). Samples of the soil were taken at approximately 1 -foot intervals. Except in Wel1 78 on the northwest side adjacent to Well 6, none of the soil contained ${ }^{134,137} \mathrm{Cs}$. The maximum ${ }^{134,137} \mathrm{Cs}$ concentration in the soil was in Well 78. It was only $53 \mathrm{pCi} / \mathrm{g}$ just beneath the pad, and concentrations decreased to background about 30 feet below the pad. Two additional wells were drilled 2 feet on each side of Well 78 (Wells 77 and 79) to a depth of 20 feet below the concrete pad. Similar radioactivity was detected in each of these three wells as shown in Table A-3. The radioactivities were not high enough to indicate large quantities of radionuclides in the ground. After obtaining the soil samples, the wells were backfilled and abandoned. No water samples were obtained from these wells.

January 1965. A permanent annulus dehumidification system was installed on each of the leaking waste tanks (including Tank 16). This system included an annulus exhaust filter and permanent purge and low flow alarm for the tank vapor space. The annulus dehumidification system had not been operated since the leak in 1960. 

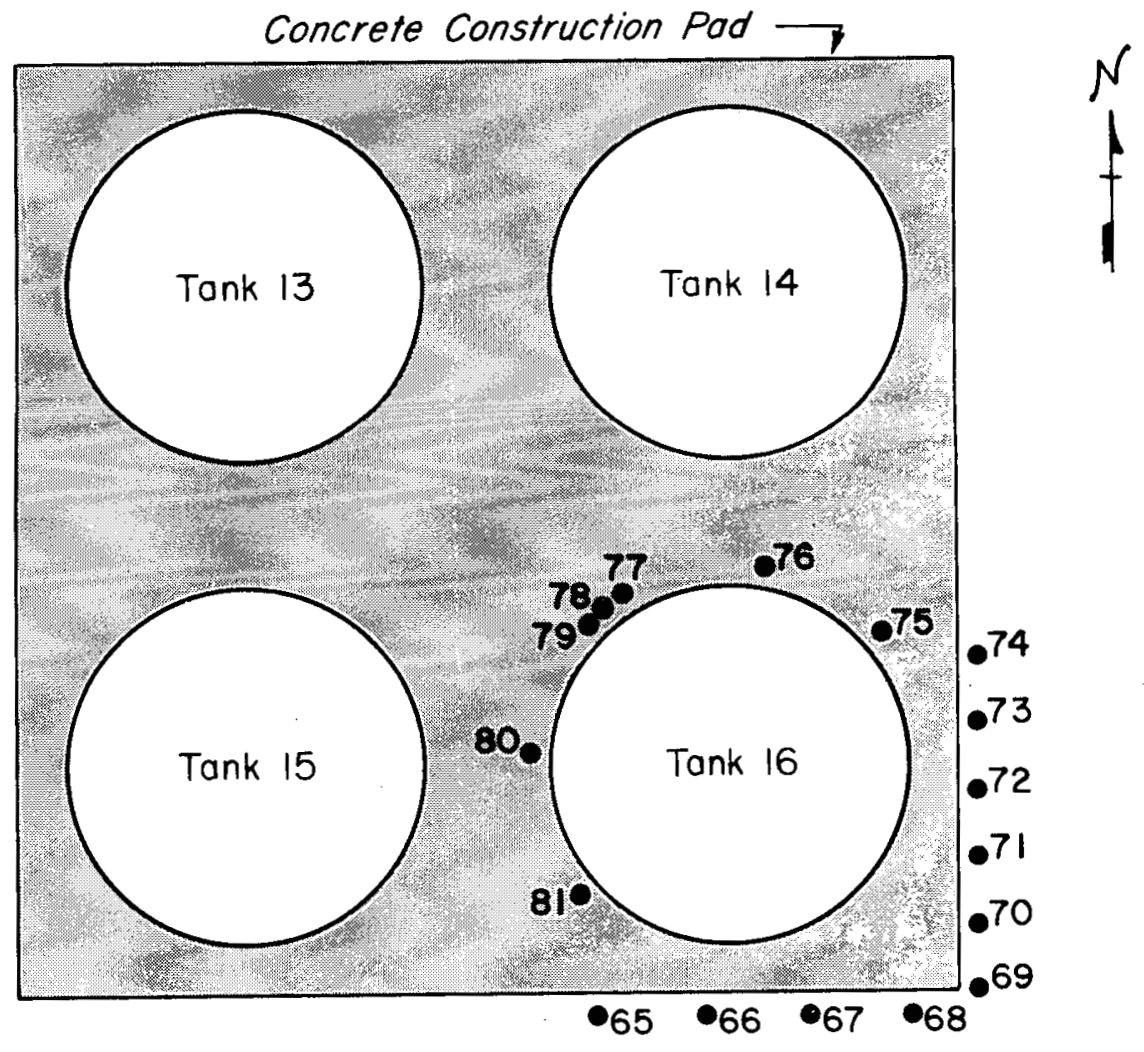

Soil Samples to Depth of 70-120 feet below Concrete Construction Pod

FIG. A-16 DEEP WELLS 
TABLE A-3

RADIOACTIVITY IN CORE SAMPLES

FROM DRY WELL BORING

\begin{tabular}{|c|c|c|c|}
\hline \multirow[b]{2}{*}{$\begin{array}{l}\text { Depth Below } \\
\text { Pad, ft }\end{array}$} & \multicolumn{3}{|c|}{$\begin{array}{c}\text { Nonvolatile Beta Emitters, } \\
\mathrm{pCi} / \mathrm{g} \text { soil }\end{array}$} \\
\hline & $\begin{array}{l}\text { Hole } 79 \\
\text { (cored) } \\
\end{array}$ & $\begin{array}{c}\text { Hole } 78 \\
\text { (augered) } \\
\end{array}$ & $\begin{array}{l}\text { Hole } 80 \\
\text { (cored) } \\
\end{array}$ \\
\hline 0 & - & 53 & - \\
\hline 1.8 & 11 & 43 & 11 \\
\hline 2.3 & 2 & - & 42 \\
\hline 2.8 & 2 & 48 & 79 \\
\hline 3.2 & 6 & - & 17 \\
\hline 3.6 & 15 & - & 3 \\
\hline 4.0 & 16 & 38 & 4 \\
\hline 4.5 & - & - & 24 \\
\hline 5.0 & 2 & 38 & 30 \\
\hline 5.5 & 1 & - & 28 \\
\hline 6.0 & 3 & 42 & 21 \\
\hline 6.8 & 181 & - & 15 \\
\hline 7.1 & 153 & 42 & - \\
\hline 7.4 & 15 & - & - \\
\hline 8.0 & - & 32 & - \\
\hline 9.0 & - & 35 & - \\
\hline 10.0 & - & 32 & - \\
\hline 11.0 & - & 22 & - \\
\hline 12.0 & - & 25 & - \\
\hline 13.0 & - & 22 & - \\
\hline 14.0 & - & 23 & - \\
\hline 15.0 & - & 19 & - \\
\hline 16.0 & - & 22 & - \\
\hline 17.0 & - & 21 & - \\
\hline 18.0 & - & 14. & - \\
\hline 19.0 & - & 16 & - \\
\hline 20.0 & - & 11 & - \\
\hline
\end{tabular}


October 1967 to June 1968. On October 10, fresh Low Activity Waste was routed to formerly leaking Waste Tank 16 to utilize the remaining freeboard below the holes cut in the upper knuckle plate to side plate weld of the tank. Frequent visual inspection of the tank annulus had shown no recurrence of leakage. Confidence in the ability to utilize the remaining space (about 420,000 gallons, up to 18 inches below the top horizontal weld) in Tank 16 was based on the demonstrated ability of waste to solidify in the seeping cracks, thus effecting closure. Tank 14 also had cracks below the liquid level that had sealed in this manner. Maintenance of a warm, dry atmosphere in the annular space was a key factor in effecting self-sealing of cracks.

Before returning Tank 16 to active service, the transfer jet from Tank 16 was tested and found to be operable, and the Tank 16 annulus jet was confirmed to be open (suction not plugged with waste salt in the annulus). The tank was filled to its reduced maximum limit in June 1968.

March 1968. Seepage of waste into the annulus was observed from an area near the middle horizontal weld on the south side of the tank. Investigation showed that the seepage, barely enough to run to the bottom of the annulus, probably resulted from insufficient flow of drying air in the annulus. When the filters on the annulus air exit were changed, the seepage nearly ceased within three days. The new air flow rates were $3100 \mathrm{cfm}$ in the annulus and $190 \mathrm{cfm}$ of tank purge. The leak was probably sealed by salt deposition from evaporation of leaked waste, in the same manner as the previous 164 known cracks in Tank 16 were sealed.

September 1968 and July to August 1969. Supernate was transferred from Tank 16 to Tank 13 .

August 1969 to July 1970. An assortment of wastes (aged High Activity Waste, evaporator concentrates, etc.) were added to and removed from the tank, finally leaving the tank at the reduced maximum level with high specific gravity (1.4 to 1.5$)$ waste.

January to March 1972. In J anuary-February 1972, periscope inspections revealed enlarged salt deposits on the tank wall and on the pan floor, and also additional leak sites. The supernate was transferred out of the tank (down to a sludge heel) in March 1972 as a first step toward taking the tank out of service. This heel consists of 67,000 gallons of sludge. This sludge consists of $47 \%$ oxides and hydroxide precipitates dispersed in supernate.

Study of the photographs obtained from the periscopic inspection showed a number of additional salt deposits (denoting cracks in the tank wall) which were not seen in photographs 
taken during the previous periscopic inspection in 1961. An exact count of the new leaks was not possible because several areas on the lower horizontal weld where individual deposits were observed in 1961 were obscured in 1972 by wide streaks of dried salt from leaks above. There was no way to determine whether the new leaks all developed shortly (i.e., within several months) after the 1961 inspection, or if they had developed gradually throughout the intervening ten years.

Generally, previously observed salt deposits on the tank wall below the current liquid level had grown in size, indicating additional seepage between the 1961 and 1972 inspections. The seepage may have occurred during the period of 1960 to 1965 when the annulus ventilation was turned off (there was no filter on the annulus exit air until March 1965), but it is also possible that extremely slow seepage since 1961 could account for the increase in salt-deposit size.

The Tank 16 annulus pan (Figure A-17) contained an irregular layer of dried salt, extending rather uniformly around the tank and estimated to be 12 to 15 inches deep. This was 7 to 10 inches more than reported under one access port in August 1967. Because the normal annulus ventilation had been employed since early 1965 , the 5 -inch accumulation of salt in the annulus is indicative of the rate of continued leakage.

The salt in the annulus of Tank 16 was probed with a coring tool. Portions of the salt were mushy, and liquid waste was seen to rise to a level of 11 to 13 inches in cored holes. The upper 5 to 6 inches were generally mushy, and the bottom 8 to 9 inches were more firm. Attempts to remove some of the liquid with the installed annulus jet were made. Liquid was jetted from the Tank 16 annulus to Tank 14 on March 8. Radiation readings at the transfer line indicated that flow continued about 20 minutes, implying removal of perhaps 1000 gallons of liquid. Liquid was still visible in the cored holes afterwards.

During this periscopic inspection and photographic study, streaks of white solids were observed on the wall of the annulus pan of Tank 16 at several locations. Figure A-17. shows these streaks of white solids. The streaks appeared to have formed from the drying of solids-bearing liquid which ran down from the top of the annulus pan. White solids were also observed on top of the ledge formed by a stiffening ring at the top of the pan and hanging down from the edge of the ledge. To determine the nature of these solids, samples were taken of the material on the ledge, material hanging from the edge of the ledge, and also from the top of the salt bed in the annulus. Attempts to scrape a sample of the streaks on the pan were hampered by the intervening ledge and poor visibility, so no sample was obtained. 


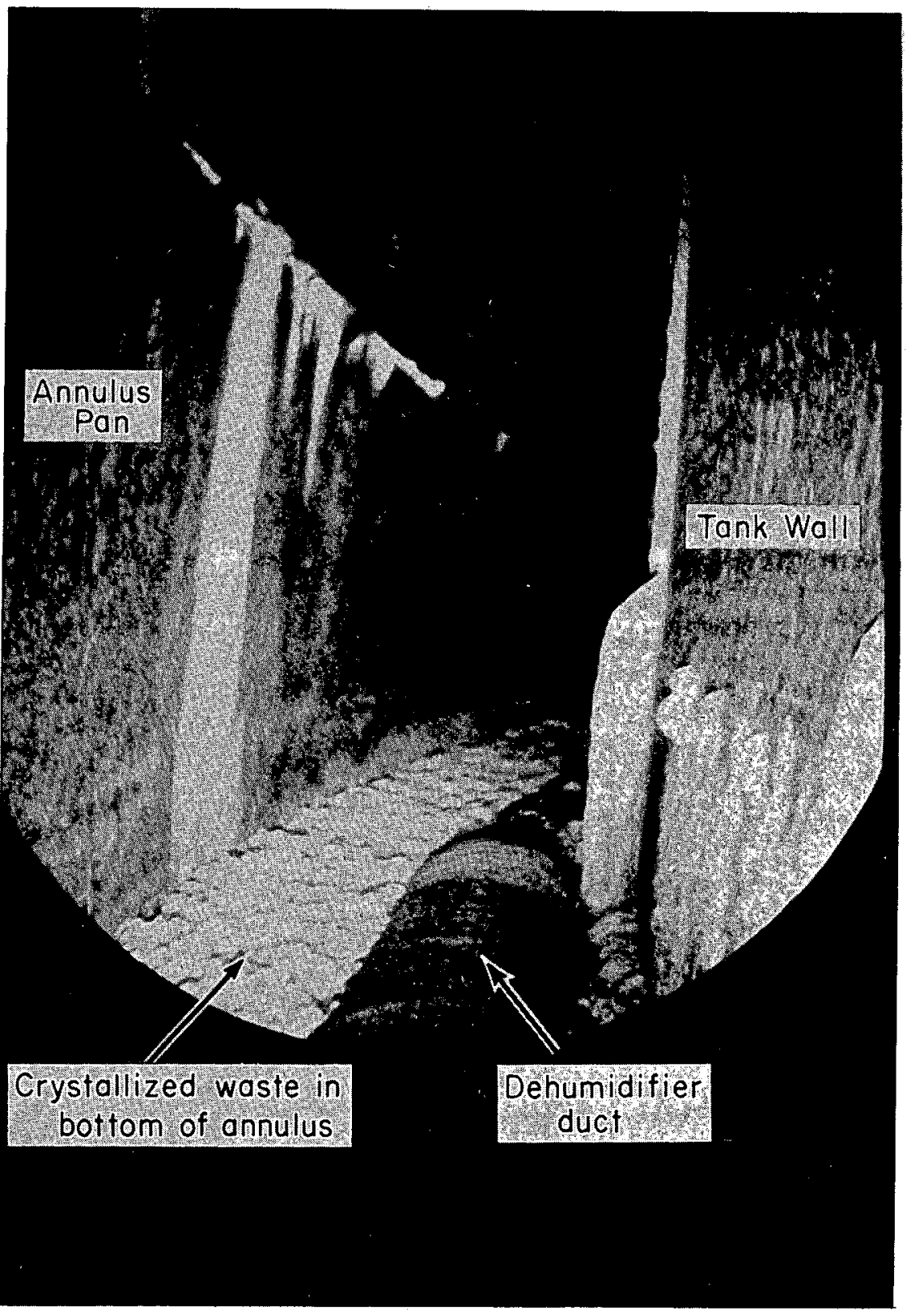

FIG. A-17 TANK 16 ANNULUS INSPECTION OF FEBRUARY 10, 1972 
TABLE A-4

\section{SAMPLES FROM TANK 16 ANNULUS}

February 1972

\begin{tabular}{|c|c|c|c|}
\hline & Top of Salt Bed & $\begin{array}{c}\text { Edge } \\
\text { of Pan Ledge } \\
\end{array}$ & $\begin{array}{c}\text { Top } \\
\text { of Pan Ledge } \\
\end{array}$ \\
\hline Description of Sample & $\begin{array}{l}\text { Wet, light } \\
\text { brown, sandy } \\
\text { appearance }\end{array}$ & $\begin{array}{l}\text { Dry solid, } \\
\text { white to } \\
\text { brown, } \\
\text { oatmeal } \\
\text { appearance }\end{array}$ & $\begin{array}{l}\text { Dry solid, white } \\
\text { and brown, oat- } \\
\text { meal appearance }\end{array}$ \\
\hline Solubility in $\mathrm{H}_{2} \mathrm{O}$, wt $\%$ & 82 & 99 & 99 \\
\hline \multicolumn{4}{|l|}{$\begin{array}{l}\text { Relative sample radiation } \\
\text { compared to top of pan } \\
\text { ledge sample }\end{array}$} \\
\hline $\begin{array}{l}\text { mrads } \\
m R\end{array}$ & $\begin{array}{l}20 \\
20\end{array}$ & 2.7 & $\begin{array}{l}1 \\
1\end{array}$ \\
\hline \multicolumn{4}{|l|}{ Radioactivity, d/(min) (g) } \\
\hline $\begin{array}{l}1{ }^{37} \mathrm{Cs} \\
13{ }^{4} \mathrm{Cs}\end{array}$ & $\begin{array}{l}1.5 \times 10^{9} \\
2.5 \times 10^{8}\end{array}$ & $\begin{array}{l}8.3 \times 10^{8} \\
5.5 \times 10^{6}\end{array}$ & $\begin{array}{l}4.5 \times 10^{8} \\
3.7 \times 10^{6}\end{array}$ \\
\hline${ }^{137} \mathrm{Cs} /{ }^{134} \mathrm{Cs}$ ratio & 6 & 151 & 122 \\
\hline $\begin{array}{l}\text { Age, years (assume } x \text { years } \\
\text { at } 13{ }^{7} \mathrm{Cs} / 13{ }^{4} \mathrm{Cs} \text { ratio of } 6 \text { ) }\end{array}$ & $x$ & $x+10.6$ & $x+9.9$ \\
\hline
\end{tabular}

Analyses (Table A-4) show that the samples were all highly radioactive and largely water-soluble. Comparison of the ${ }^{13} \mathrm{Cs}$ to ${ }^{134} \mathrm{Cs}$ ratios indicates that the ledge material was 10 years older than the material in the upper layer of the bulk salt in the pan. Presumably the material on the ledge was a portion of the waste that leaked out of the tank in September 1960, and the top layer of salt in the annulus was leakage of waste recently added to the tank. Neither the salt streaks on the pan wall nor the salt on the pan ledge was visible in color photographs taken through the periscope following the annulus pan overfill. Thorough examinations were also made in 1961 and 1962. Therefore, it must be assumed that the streaks formed since that time. Two hypotheses could explain the pan-wall salt; both assume that some part of the waste that leaked from the pan in 1960 had been retained in some space outside the pan and returned to the pan later. The hypotheses are :

- Increased hydraulic loadings as the tank was filling or refilling may have decreased the volume between the pan and concrete encasement, forcing some of the waste from beneath the pan back into the annulus. 
- Waste between the pan and the concrete slab (or, conceivably, even in the earth surrounding the tank) may have been carried or displaced into the annulus by slow inleakage of ground water. Appendix E shows that the ground water elevation near Tank 16 has been above the pan top for considerable time during the interim.

August to September 1973. Water from the water addition system was again pumped continuously to determine the radioactivity levels remaining. The cesium removed from the water addition system was not removed by vermiculite ion exchange as had been done previously, but was discharged directly to the seepage basin. Figure A-13 shows the radioactivity, which was very low. 


\section{APPENDIX B}

\section{EXTENDED MONITORING PROGRAM}

Several of the wells discussed in Appendix A have been sampled as part of the environmental monitoring program at Savannah River since the overfill of the Tank 16 annulus pan in September 1960. This appendix describes the results of this extended monitoring. The data (collected over long periods of time) are important in detecting relative movement (direction and rates) of the leaked radioactivity. They support knowledge determined from modeling of radioactivity movement through the soil and confirm that the leaked radioactivity has moved only a short distance since the leak.

\section{SAMPLING ABOVE CONSTRUCTION PAD}

Figure B-1 (similar to Figure A-9 of Appendix A) shows the radioactivity of water samples taken from immediately above the construction pad (Figure B-2) from September 27, 1960 to March 26, 1961. (These wells are located five feet from Tank 16.) Several key points are:

- Water was pumped continuously from Well 6 at a rate of 1.26 liters/min from September 23 to March 26. Samples from the other 3 wells were dip samples.

- Water from We11 6 remained near background for about 11 days after the pumping began, then radioactivity appeared. The radioactivity level of the water from Well 6 increased, reaching a maximum of $\sim 7 \times 10^{5} \mathrm{pCi} / \ell$. Pumping of this well created a small cone of depression drawing radioactivity to the well along with the ground water.

- When a pump was inserted in the water addition system and operated, the radioactivity in Well 6 immediately started to decrease, and was stil1 decreasing when pumping of Well 6 and its sampling were discontinued.

- The radioactivity level of the water in the unpumped wells remained essentially constant at 10 to $25 \mathrm{pCi} / 1$ iter until the pump in the water addition system was started. The radioactivity in these unpumped wells then increased to the range of 50 to 250 $\mathrm{pCi} / \mathrm{l}$. This increase was probably due to the spread of radioactivity in the water addition system when pumping was begun and the pumped contents were returned to the water addition system (December 1960 and January 1961, see Figure A-13 of Appendix A). 


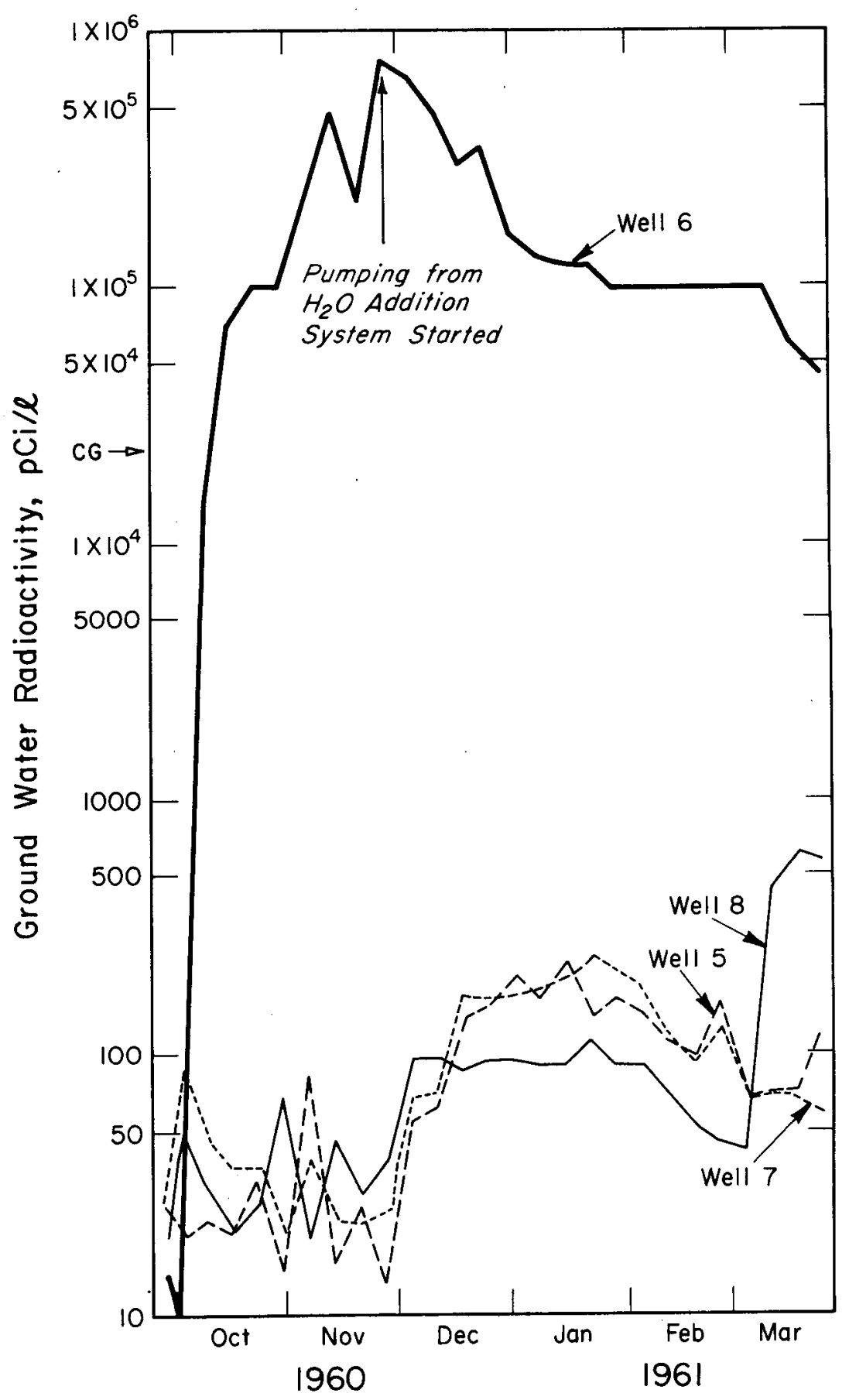

FIG. B-1 GROUND WATER RADIOACTIVITY SAMPLED ABOVE CONSTRUCTION PAD 


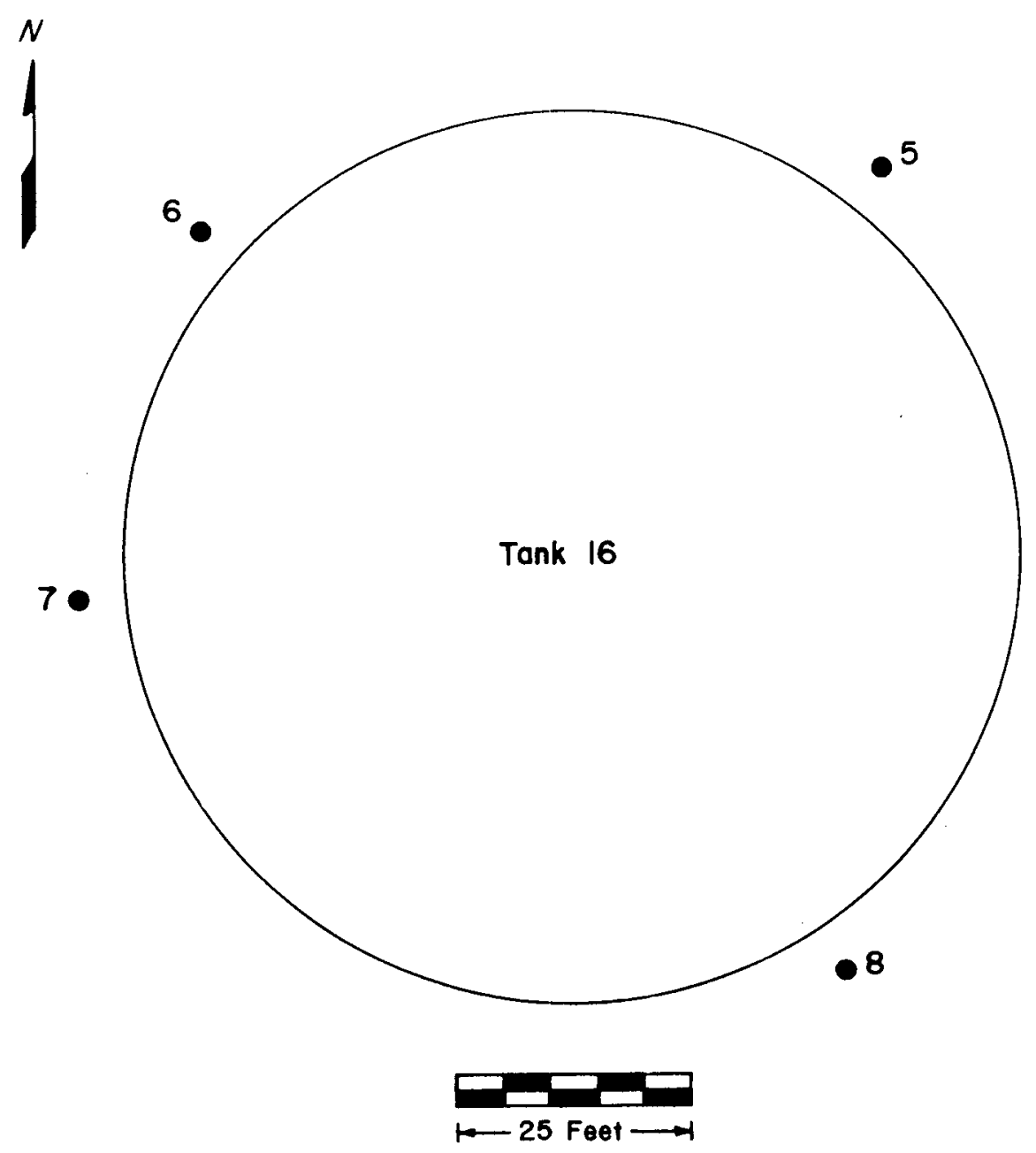

Ground Woter Somple above Concrete Construction Pad

FIG. B-2 WELLS ABOVE CONSTRUCTION PAD 
Figure B-3 shows the results of the extended semiannual sampling program for Wells 5, 7, and 8. These samples show that the radioactivity in the ground water above the construction pad has remained higher than background levels (5-15 pCi/l) since the overfill of Tank 16 annulus pan. The significance of the changes for an individual well is not known. Overall, the sample data on the NE side of the tank (Well 5) has generally decreased, whereas wells on the SE and $W$ sides (We11s 7 and 8) have increased. The wells were so close to the tank that local effects appear to dominate the normal ground water flow pattern, which is flow in a northeasterly direction.

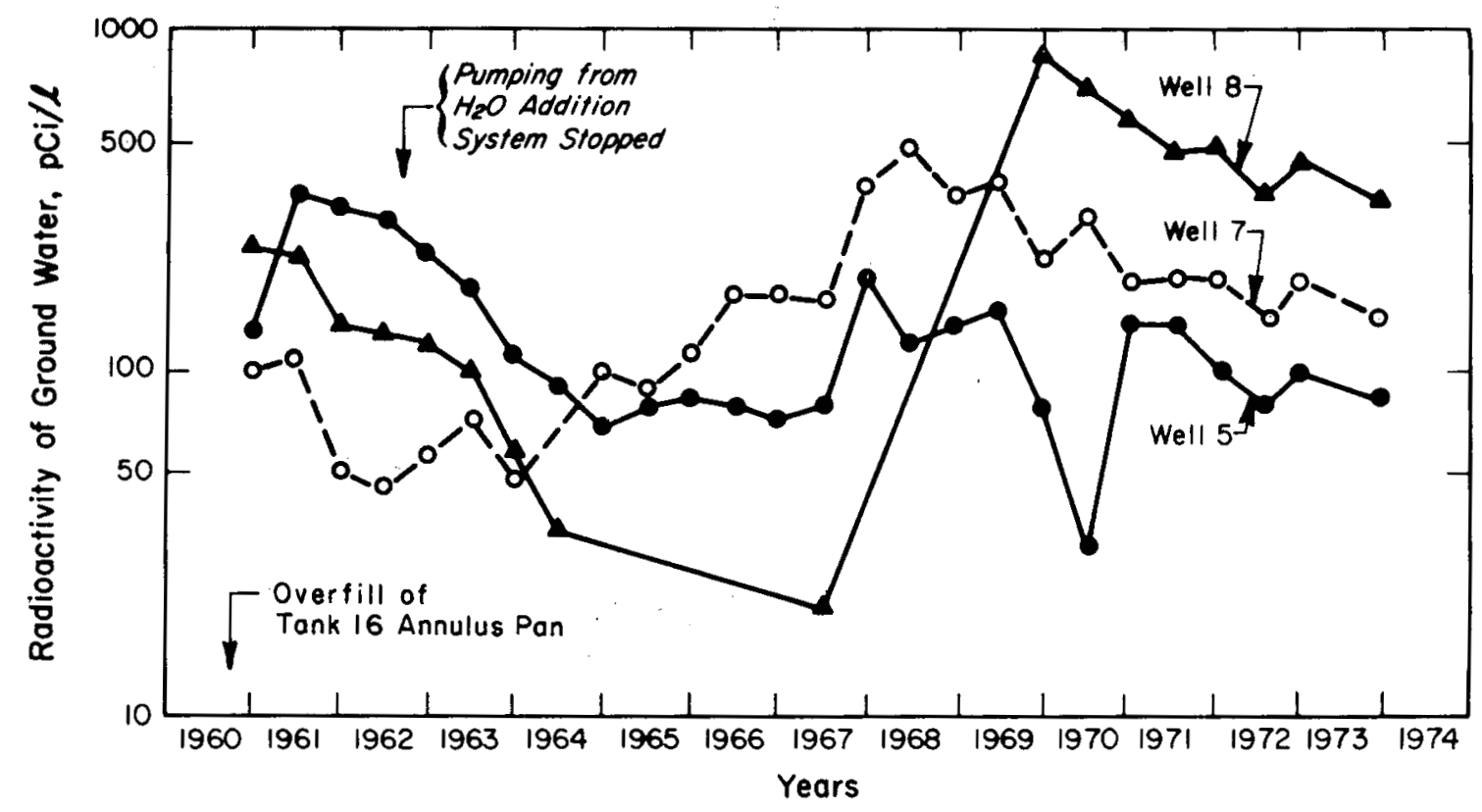

FIG. B-3 GROUND WATER RADIOACTIVITY ABOVE CONSTRUCTION PAD 
The radioactivity in the ground water directly below the construction pad has been measured in the water addition system and in We11 2 (Figure B-4). The radioactivity profile of the water removed from the water addition system was given in Figure A-13 of Appendix A. This information is also given in Figure B-5 as monthly averages; short periods of time when this system was not pumped and sampled are not shown. Radioactivity was detected in the first sample withdrawn from this system (about 82 days after the Tank 16 annulus pan overfill) and has decreased steadily since.

Dip samples taken from Well 2, located near the center of the construction pad and about 10 feet deeper than the water addition system (Figure B-4); showed water radioactivity slightly above background almost immediately after the Tank 16 annulus pan overfill (Figure B-5). A significant increase was observed 9 to 10 months later and the radioactivity approached that of the water in the water addition system. The radioactivity reached a peak in SeptemberNovember 1961 (about 14 months after the overfill) and has since decreased. Figure B-6, which is based on six-month averages, shows Wel1 2 radioactivity over a longer time than is shown on Figure B-5.

Ground water samples taken 15 feet from the edge and 10 feet below the construction pad (35 feet from the edge and 10 feet below Waste Tank 16 bottom) are shown on Figures B-7, 8, and 9 . Locations of the wells are given on Figure B-4. The data points are not identified on Figures $B-7$ and 8 since there appears to be no correlation from well to well. The data points for each side of the waste tank are enclosed in an envelope on the figures to show relative radioactivities. These figures show that radioactivity is slowly moving to the east and south. The water on the north side of the tank (Figure B-7) remained at background. The radioactivity of the ground water from Well 54 (on the northwest side of the tank) increased. This indicates radioactivity initially moved northwest with the water flow (water table gradient at the time of the overfill was to the northwest). Then, as the water flow turned to the northeast, the radioactivity decreased to background. The ground water south of the tank area is about three times background radioactivity (Figure B-8). One well (Number 3 ) to the east of the tank area has 10 to 100 times the radioactivity of the other wells. This well is on the probable ground water flow path. However, the other wells on the east side of Tank 16 are also on this normal flow path and their mean is only two times background. This indicates the radioactivity flowed through a zone of higher permeability from the point of leakage to Well 3. Sampling of Well 3 was discontinued in 1966 due to pluggage of the well.

Statistical analyses of the data given on Figures B-7, 8, and 9 are presented in Table B-1. 


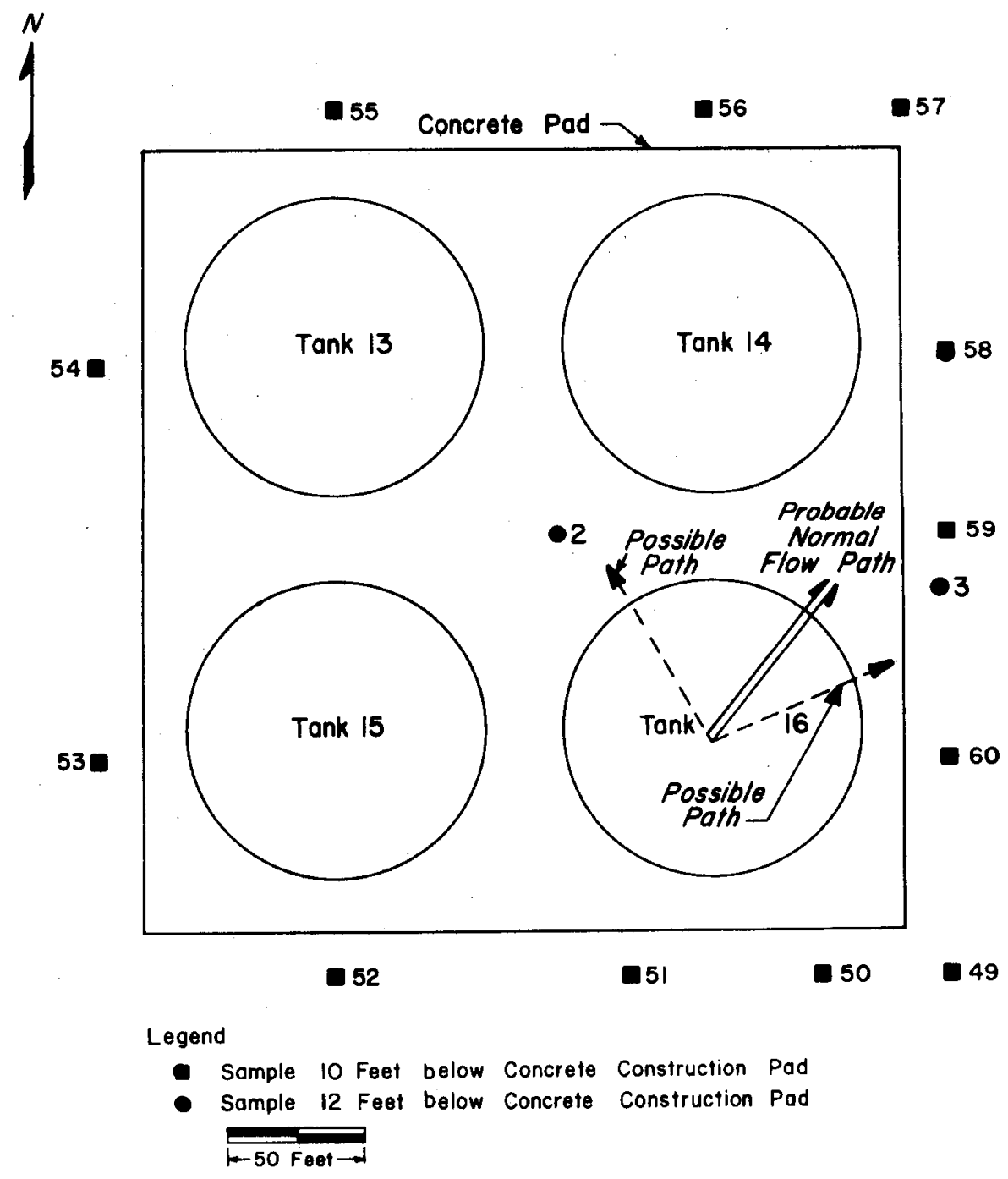

FIG. B-4 WELLS BELOW CONSTRUCTION PAD 


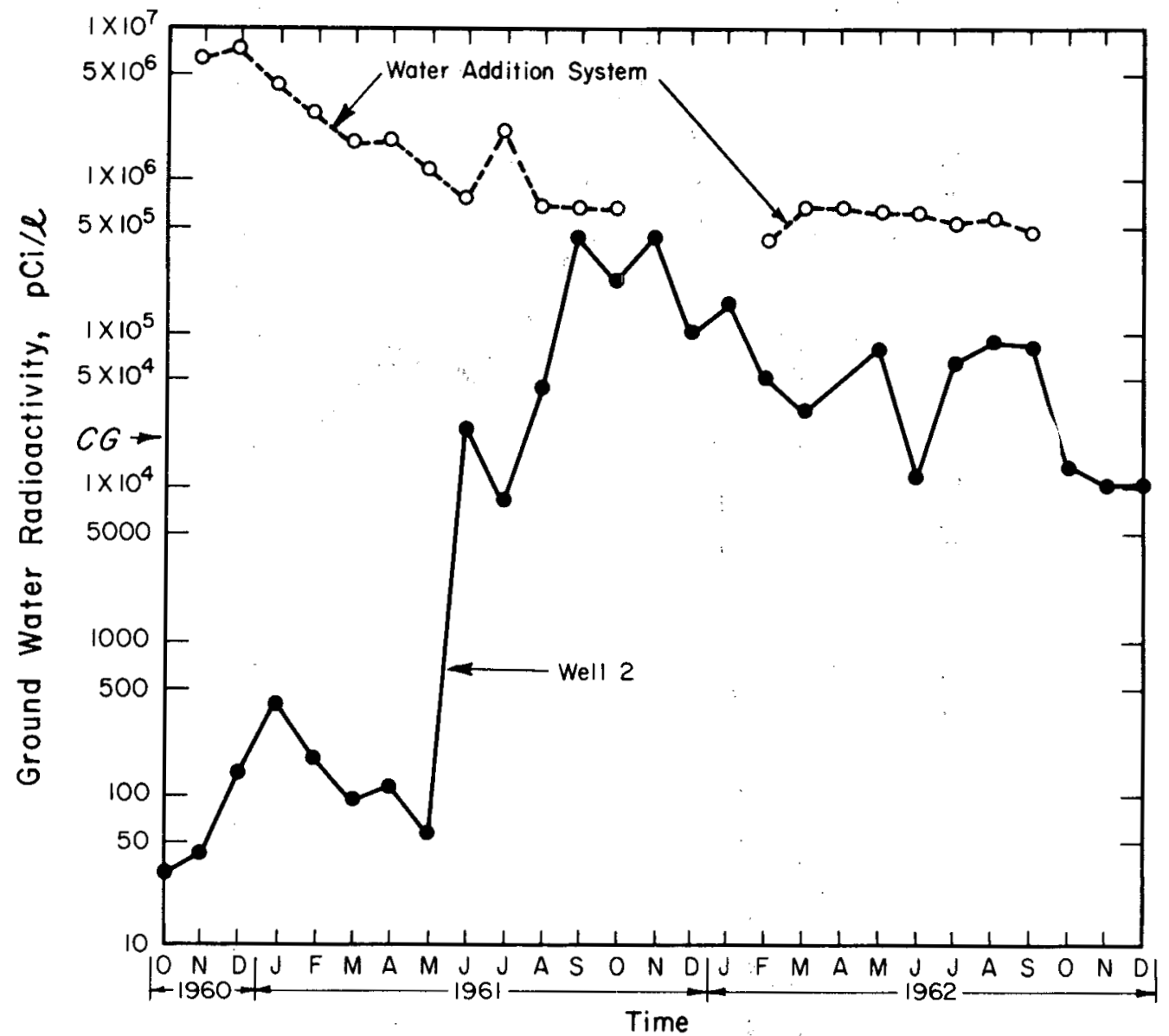

FIG. B-5 GROUND WATER RADIOACTIVITY BELOW CONSTRUCTION PAD 


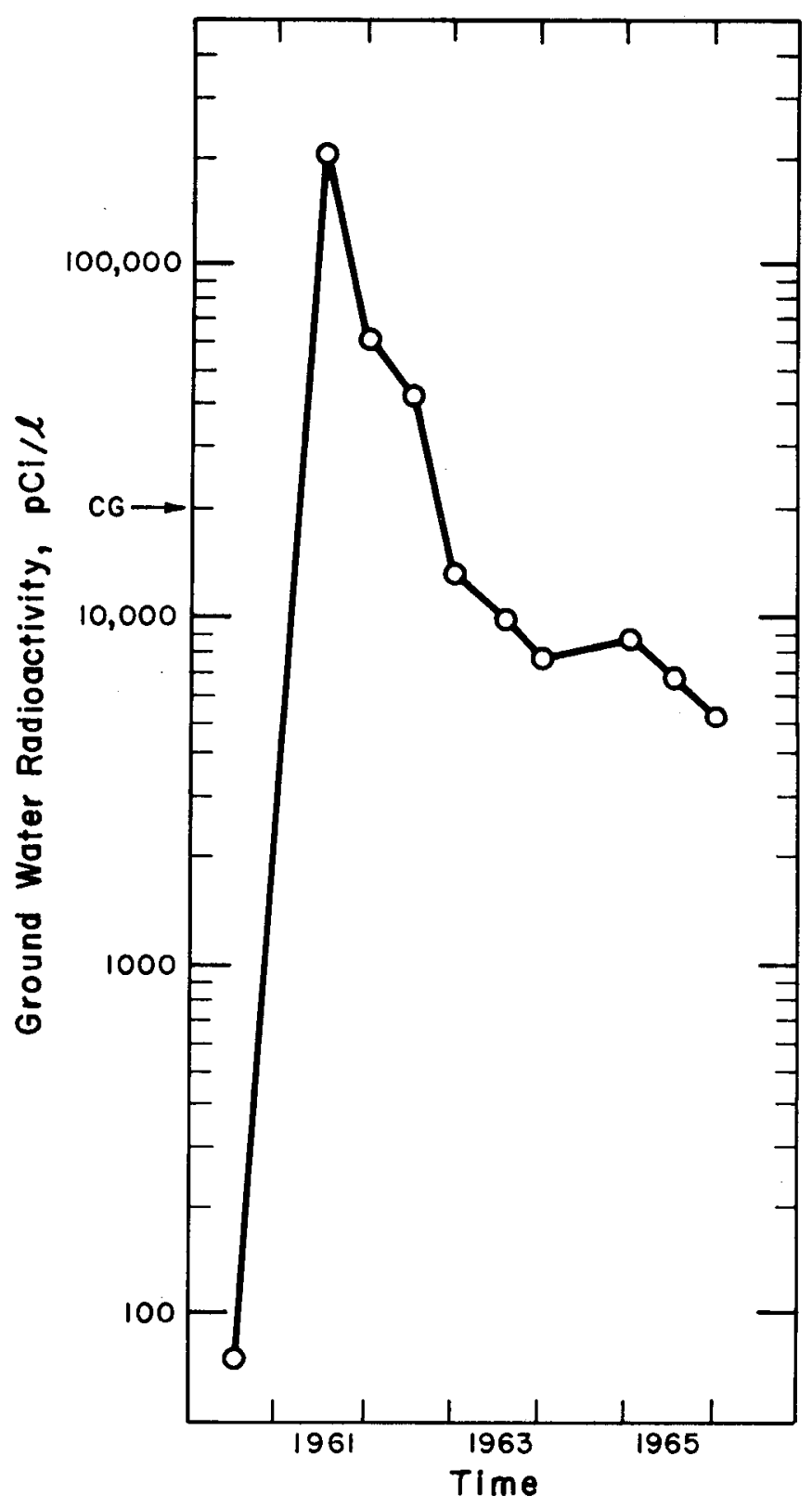

FIG. B-6 GROUND WATER RADIOACTIVITY FROM WELL 2

B-8 


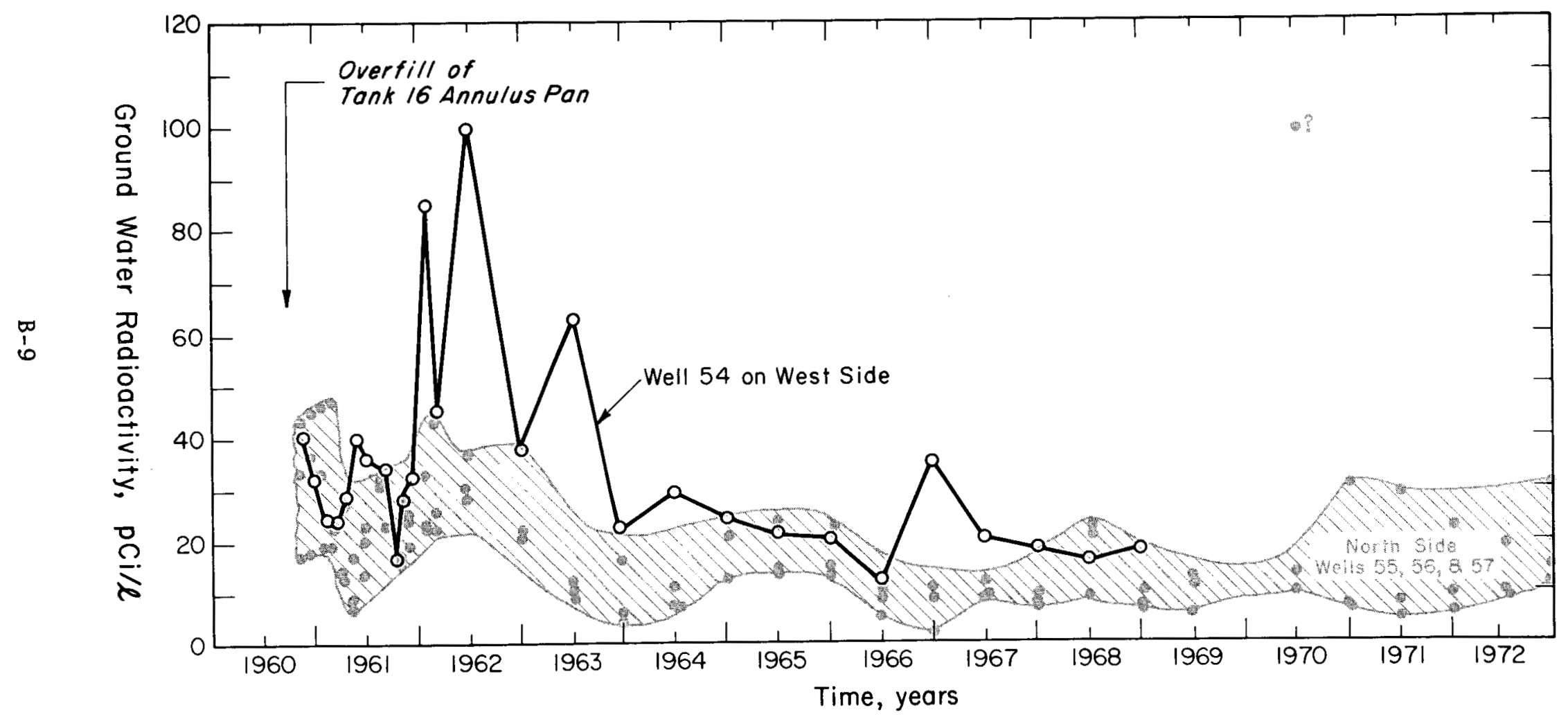

FIG. B-7 GROUND WATER RADIOACTIVITY 15 FT FROM AND 10 FT BELOW CONSTRUCTION PAD NORTH AND WEST SIDES 


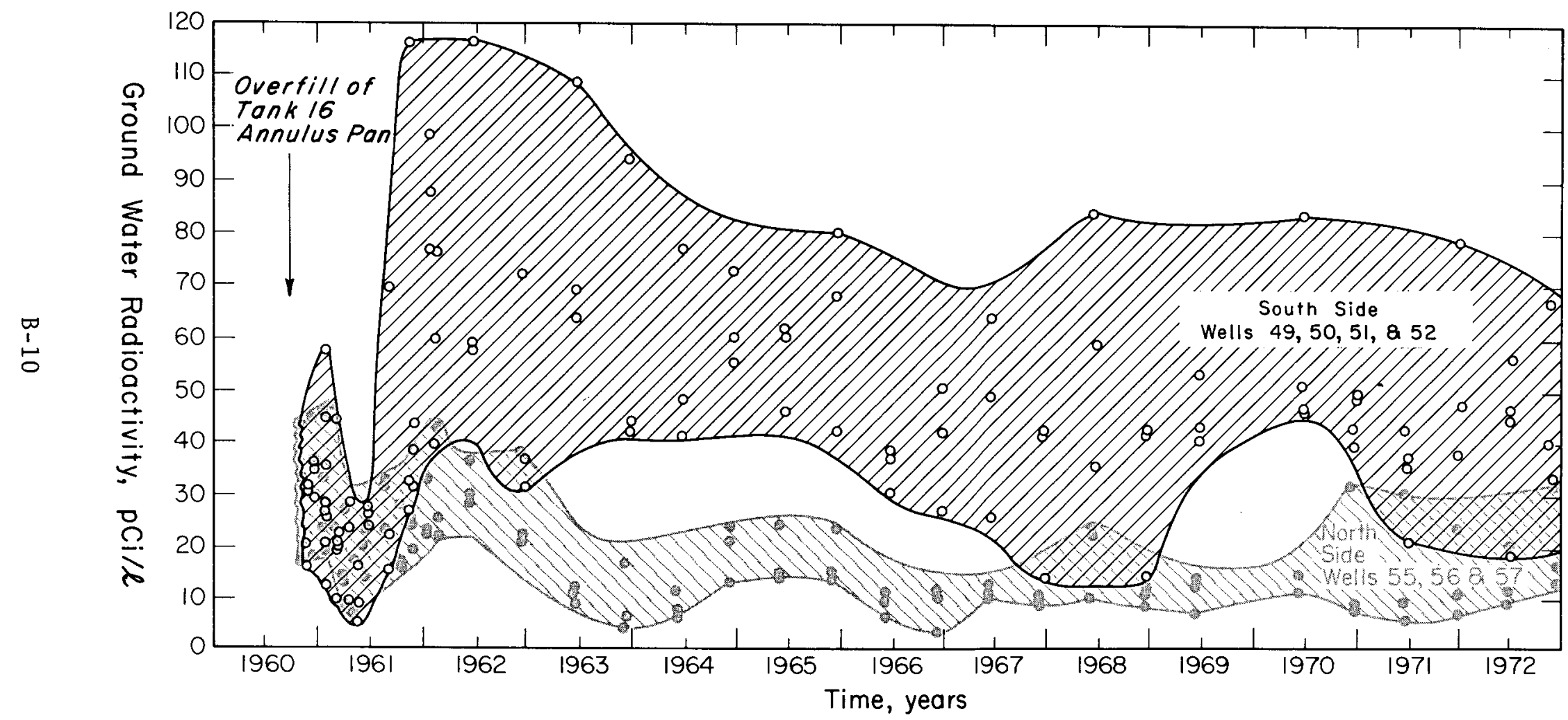

FIG. B-8 GROUND WATER RADIOACTIVITY 15 FT FROM AND 10 FT BELOW CONSTRUCTION PAD NORTH AND SOUTH SIDES

O 


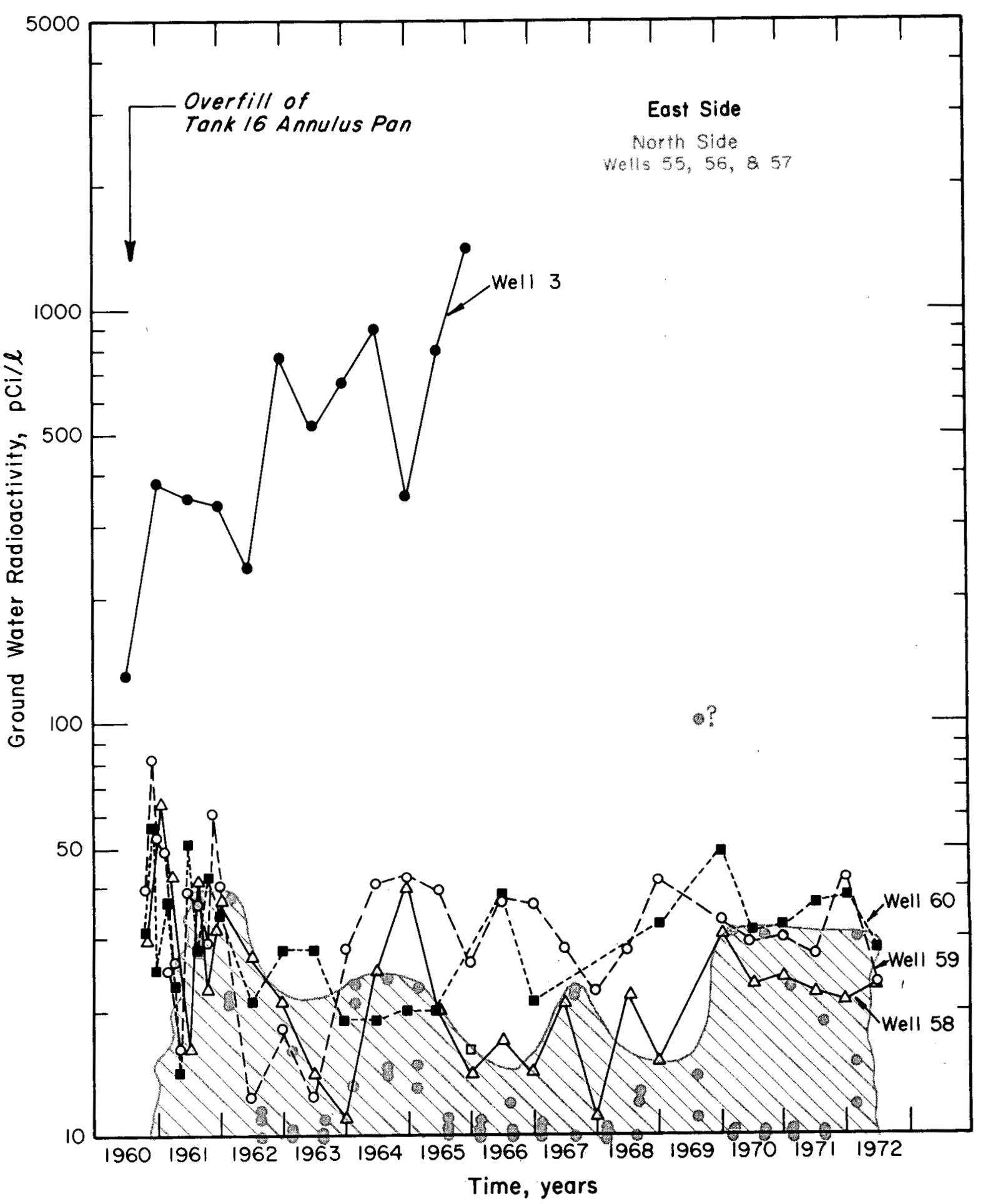

FIG. B-9 GROUND WATER RADIOACTIVITY 15 FT FROM AND $10 \mathrm{FT}$ BELOW CONSTRUCTION PAD NORTH AND EAST SIDES 
TABLE B-1

STATISTICAL ANALYSIS OF GROUND WATER RADIOACTIVITY

15 FT FROM AND $10 \mathrm{FT}$ BELOW CONSTRUCTION PAD

Radioactivity of 'Ground Water, $\mathrm{pC} i / 1$

\begin{tabular}{|c|c|c|c|c|c|c|c|}
\hline Well & Location & $\begin{array}{l}\text { Range of } \\
\text { Data }\end{array}$ & $\begin{array}{l}\text { Mean Con- } \\
\text { centration }\end{array}$ & 10 & $\begin{array}{l}\text { Range of } \\
\text { Data }\end{array}$ & $\begin{array}{l}\text { Mean Con- } \\
\text { centration }\end{array}$ & 10 \\
\hline 55 & $\mathrm{~N}$ & $6-30$ & 10.2 & 5.5 & & & \\
\hline 56 & $\mathrm{~N}$ & $9-38^{*}$ & 18.9 & 9.2 & $2-38^{*}$ & 8.4 & 14.3 \\
\hline 57 & N & $2-31$ & 13.0 & 8.3 & & & \\
\hline 58 & E & $11-37$ & 21.7 & 7.8 & $11-49$ & 26.8 & 9.4 \\
\hline 59 & E & $12-42$ & 28.9 & 11.0 & & & \\
\hline 60 & E & $16-49$ & 28.3 & $8.8)$ & $11-1400$ & 119.9 & 250.7 \\
\hline 3 & $\mathrm{E}$ & $130-1400$ & 578.3 & 351.0 & & & \\
\hline 49 & $S$ & $19-84$ & 47.7 & 15.6 & & & \\
\hline 50 & S & $18-117$ & 57.6 & 26.2 & $14-117$ & 49.9 & 20.1 \\
\hline 51 & $\mathrm{~S}$ & $35-83$ & 59.3 & 19.9 & & & \\
\hline 52 & $S$ & $14-64$ & 41.7 & 13.5 & & & \\
\hline 53 & w & ** & ** & $* *$ & & & \\
\hline 54 & $w$ & $12-100$ & 30.3 & 24.3 & $12-100$ & 30.3 & 24.3 \\
\hline
\end{tabular}

* A single sample analyzing $100 \mathrm{pCi} / 1$ was eliminated

** No samples

Several of the normal ground water monitoring wells, located in a rough semi-circle ranging from 1700 to 2800 feet from Tank 16, have shown no indication of increased radioactivity as a result of the Tank 16 annulus pan overfill. The locations of these wells are shown on Figure $B-10$. The ground water radioactivity monitored in these wells is shown on Figure B-11. As can be seen, the water radioactivity has been $<25 \mathrm{pCi} / 1$ iter or about background level. The mean concentration for the values is 7.8 and the one sigma range is \pm 3.6 $\mathrm{pCi} /$ liter. 


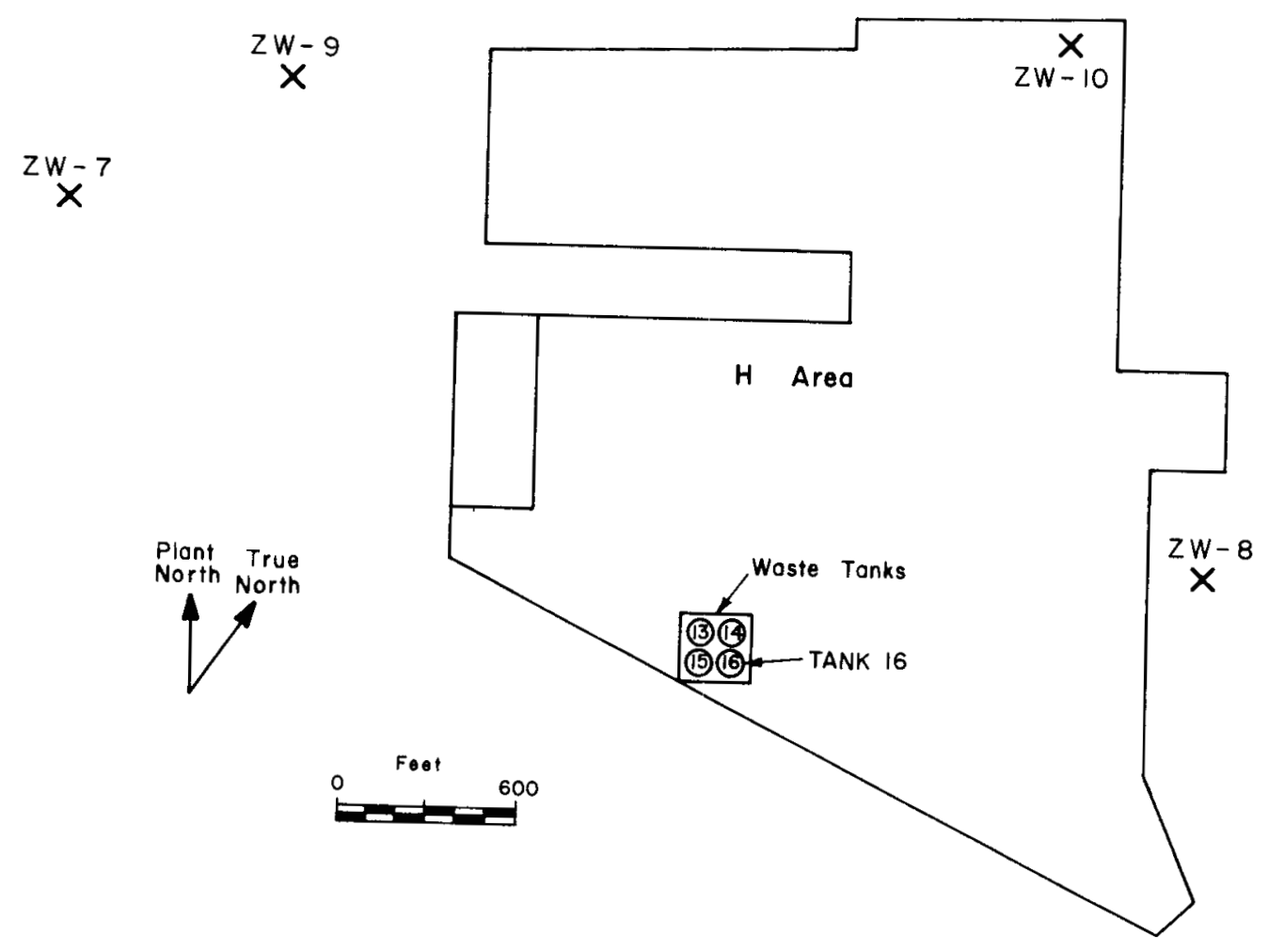

FIG. B-10 H-AREA MONITORING WELLS 1700-2800 FT FROM TANK 16

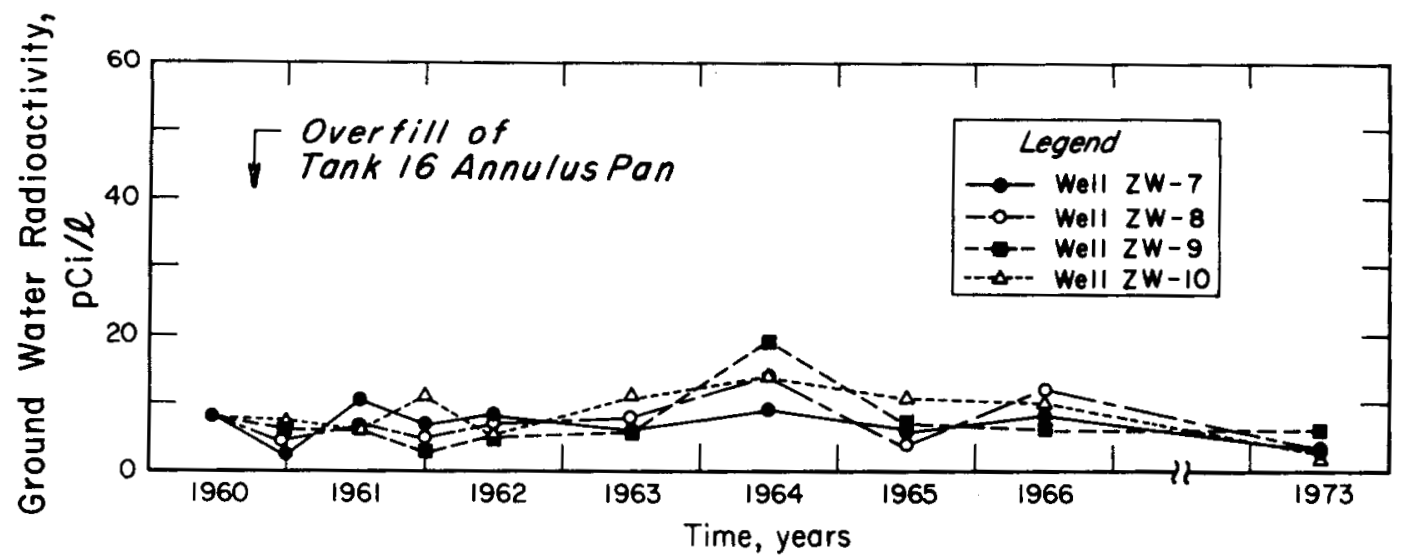

FIG. B-11 GROUND WATER RADIOACTIVITY 1700-2800 FT FROM TANK 16 


\section{APPENDIX C \\ FACTORS INFLUENCING MIGRATION OF RADIONUCLIDES IN SRP SOILS}

\section{ION EXCHANGE}

Soils present in the water table in the 200 Area are clayey sand or sandy clay containing 20 to $40 \%$ clay. The dominant clay mineral is kaolinite with small amounts of other clays including weathered mica.' According to Grim ${ }^{1 *}$, kaolinite clays are aluminosilicates and are made up of alternate layers of silica and alumina.

The ion exchange properties of the Savannah River Plant (SRP) soils are due mainly to the presence of clays within the soil complex. There are three causes of cation exchange in clay minerals, but in kaolinite clays only the first two are of any consequence. The third is important in the weathered mica in the SRP soil.

- Broken bonds around the edges of the silica-alumina units give rise to unsatisfied charges, which would be balanced by sorbed cations.

- The hydrogen of exposed hydroxyls may be replaced by an exchangeable cation.

- Substitutions within the lattice structure of trivalent aluminum and other lower valence ions for quadrivalent silicon in the tetrahedral sheet result in unbalanced charges in the structural units of some clay minerals. In kaolinite clays, the layers of silica and alumina are closely packed and do not exhibit ionic substitution within the crystal lattice.

In the kaolinite clays, the charges originate from the exposed valence bonds at broken bonds, at broken corners, and at edges. Charges also originate from the ionization of exposed hydroxyl groups, such as:

$$
\supseteq \mathrm{Si}-\mathrm{OH}+\mathrm{H}_{2} \mathrm{O} \Longrightarrow \mathrm{SiO}^{-}+\mathrm{H}_{3} \mathrm{O}^{+}
$$

* References for this appendix are on page $\mathrm{C}-10$. 
The negative charge increases with $\mathrm{pH}$ as a result of increased ionization of the acidic group. Kaolinite clays, therefore, have variable exchange capacities depending on $\mathrm{pH}$. The exchange capacity ${ }^{2}$ of the water-table soils at SRP is given in the following table.

Exchange Capacity of Water-Table Soil
$\begin{array}{rcc}\mathrm{pH} & \mathrm{meq} / 100 \mathrm{~g} \text { Soil } \\ 4 & 0.01 & \mathrm{meq} / 100 \mathrm{~g} \mathrm{Clay} \\ 5 & 0.11 & 0.06 \\ 6 & 0.37 & 0.54 \\ 7 & 0.50 & 1.9 \\ 8 & 0.60 & 2.5 \\ 9 & 0.74 & 3.0 \\ 10 & 1.2 & 3.7 \\ \end{array}$

The rate of cation exchange varies with the clay mineral, the concentration of the cations, and the nature and concentration of the anions. In general, the reaction of cations with kaolinite is almost instantaneous.

In general, the ability of cations to be absorbed or eluted from ion exchange media depends on their valence (i.e., the higher the valence of the sorbing ion the more strongly it is absorbed and retained during elution). In addition, most resins have specificity characteristics for certain cations resulting in these cations being absorbed or eluted preferentially according to general rules. Sorption of cations like cesium or strontium by kaolinite soils is inhibited by the presence of metal ions like sodium or aluminum, and hydrogen ions, probably due to mass action. Maximum sorption occurs between $\mathrm{pH} 7$ and 9 (Figure $\mathrm{C}-1$ ). The effect of $\mathrm{pH}$ on the sorption of contaminants that are readily hydrolyzed in solution (such as $\mathrm{Zr}-\mathrm{Nb}, \mathrm{Sr}$, and $\mathrm{Pu}$ ) is complicated by the formation of hydrolytic species and precipitates at high $\mathrm{pH}$.

Distribution coefficients, the relative concentration of a cation in the soil to that in the solution after equilibrium is reached, have been measured for most of the significant contaminants of high activity waste using soil obtained beneath the waste tanks. The distribution coefficients for radionuclides are low in high salt solutions because of the competition for ion exchange sites on the soil by the other ions in solution. As the high salt solution is diluted with ground water the distribution coefficient increases rapidly. In addition, the stable chemicals in the waste that provide the competition move ahead, leaving the radionuclides 
to reach equilibrium with the ground water system. The distribution coefficients for cesium were measured in various dilutions of high activity waste to provide a basis for predicting the transient conditions that exist before equilibrium is established. The following table shows these results:

\begin{tabular}{|c|c|c|}
\hline $\begin{array}{l}\text { Dilution } \\
\text { Factor } \\
\end{array}$ & $\begin{array}{c}\text { Solution } \\
\mathrm{pH} \\
\end{array}$ & $\begin{array}{c}\text { Distribution Coefficient } \\
\text { for } \mathrm{Cs} \\
\end{array}$ \\
\hline None & ح14 & 1.5 \\
\hline 10 & $\sim 13$ & 15 \\
\hline 100 & $\sim 12$ & 80 \\
\hline 1000 & $\sim 11$ & 180 \\
\hline Large & 7.5 & 1000 \\
\hline
\end{tabular}

As equilibrium is approached, distribution coefficients like those shown in Figure $\mathrm{C}-1$ will apply. If a $\mathrm{pH}$ of about 7.5 is selected (a value that might result if alkaline waste is diluted with SRP ground water of $\mathrm{pH} 6.3$ to 6.8 ), the distribution coefficients are $\mathrm{Sr} 800, \mathrm{Cs} 1000$, and Pu-IV 8000. These indicate that the relative rates of migration would be $\mathrm{Sr}>\mathrm{Cs}>\mathrm{Pu}-\mathrm{IV}$.

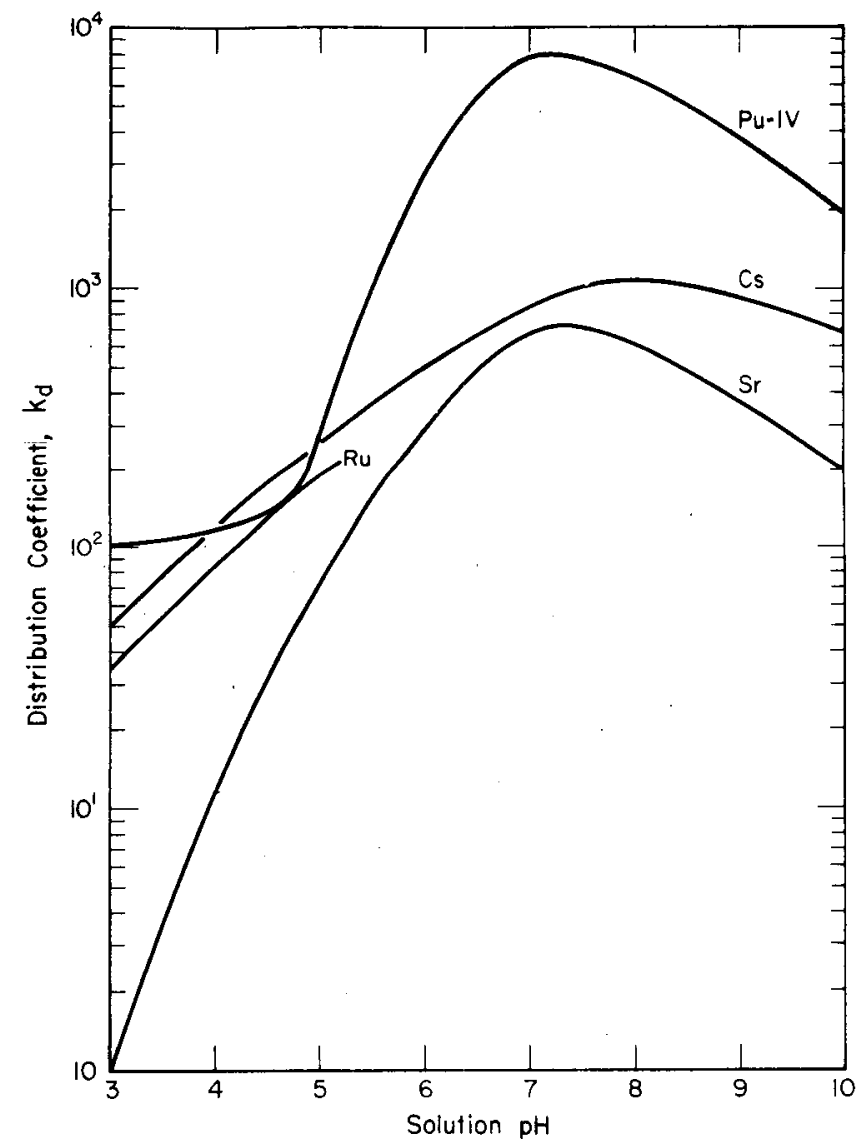

FIG. C-1 SORPTION OF VARIOUS CATIONS BY SRP SOILS C-3 
Distribution coefficients for ruthenium from alkaline waste in ground water have not been measured in SRP soils. Ruthenium chemistry indicates that the effective distribution coefficient might be low under ground water conditions, and that the rate of migration of ruthenium would trail that of ground water only slightly. The chemistry of ruthenium is complex since it forms many compounds, some of which act as anions and others as cations. Figure $\mathrm{C}-1$ shows the measured distribution coefficients for ruthenium in the soil under low $\mathrm{pH}$ conditions. The ruthenium complexes in alkaline waste would probably be $\operatorname{RuNO}(\mathrm{OH})_{2}\left(\mathrm{H}_{2} \mathrm{O}\right)_{3}$, $\operatorname{RuNO}(\mathrm{OH})_{4}\left(\mathrm{H}_{2} \mathrm{O}\right)^{-}$, and $\operatorname{RuNO}\left(\mathrm{NO}_{2}\right)_{4}(\mathrm{OH})^{=}$. The former would act as a weak cation and the latter two as anions. As the alkaline waste is diluted with ground water, the $\mathrm{RuNO}(\mathrm{OH})_{4}\left(\mathrm{H}_{2} \mathrm{O}\right)^{-}$ would tend to slowly convert to $\mathrm{RuNO}(\mathrm{OH})_{3}\left(\mathrm{H}_{2} \mathrm{O}\right)_{2}$, which at a pH of $\sim 7$ would precipitate, and probably be filtered from the ground water-waste mixture, giving an indication of a large effective distribution coefficient. This, of course, would result in a significant discontinuity in the distribution coefficient curve. The location of this discontinuity has not been established.

\section{Cesium Fixation}

The measured rate of movement of cesium is much slower than would be predicted by distribution coefficients discussed above. This is due to a phenomena called cesium "fixation." ${ }^{3}$ Potassium, cesium, and other cations having similar ionic radii are entrapped in interlayer lattice holes of weathered mica as first described by Page and Baver. ${ }^{4}$ This reaction is influenced by other cations in the soil, e.g., the stable sodium in waste. Several investigations $5,6,7,6$ showed this fixation could be explained by the degree of lattice expansion. 9,10

Mica minerals in the SRP soil are in various stages of weathering so that the interlayer planar surfaces are occupied by all of the various cations in soil. The distance between unit layers is determined by the cations adsorbed between the layers. For the cations of interest in SRP soil, the distances between unit layers are $\mathrm{Ca}(15.07)$ *, $\mathrm{H}(14.33)$ *, $\mathrm{Na}(12.56)$ *, Cs $(11.97)^{*}$, and $K(10.42)^{*}$. Three possible configurations of the crystal lattice of mica minerals depending upon the interlayer cations are shown in Figure $\mathrm{C}-2$. The contracted lattice (Figure C-2A) of unweathered mica contains only potassium ions, and interlayer exchange sites are restricted. The expanded lattice (Figure $\mathrm{C}-2 \mathrm{C}$ ) permits easy access by any cation smaller

* Basal reflection $\mathrm{d}(002)$ in $\AA$ as obtained with vermiculite. 10 These are due to differences in the hydrated radii of the cations when adsorbed in the interlayer space and are quite different from those of the cations in solution. 
than the lattice-expanding cation to the interlayer exchange sites. Along the front where weathering is in progress, there is a change in the space between layers. This change in spacing extends from the weathered area inward to the unweathered mineral. This results in a wedge-shaped space for partially weathered mica minerals (Figure C-2B). Exchange of the larger hydrated cations for cesium is hindered in this area because the larger ions can enter this space on1y with difficulty. Cesium exchange will progress along this front only as the lattice expands. This is one phase of cesium fixation. If potassium ions are available and replace the expanding cations in the weathered area, the lattice will collapse and trap cesium within the interlayer area (Figure C-2D). Fixation is then complete, and the mineral will have to be reweathered from the edge of the sheet to the former weathering front before cesium exchange will resume. Since sodium can expand the lattice sufficiently for cesium to enter when high activity waste enters the soil, the large concentration of sodium will significantly increase cesium fixation and thereby reduce the migration rate of cesium through the soil.

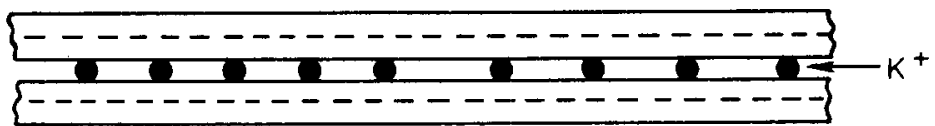

A. Unweathered, contracted lattice

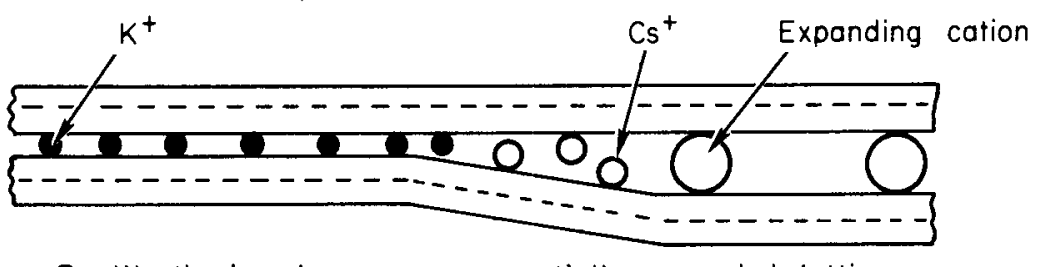

B. Weathering in progress, partially expanded lattice

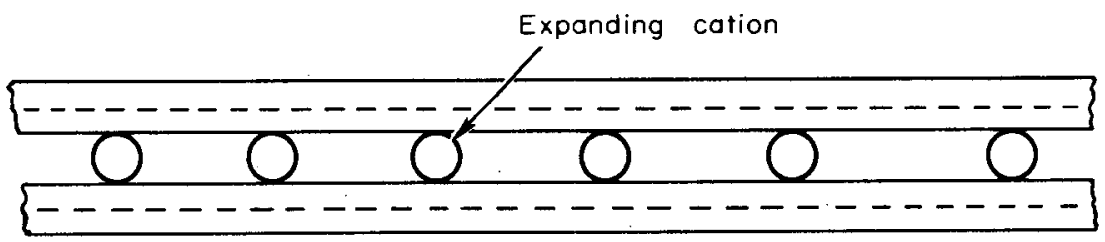

C. Weathered, fully expanded lattice

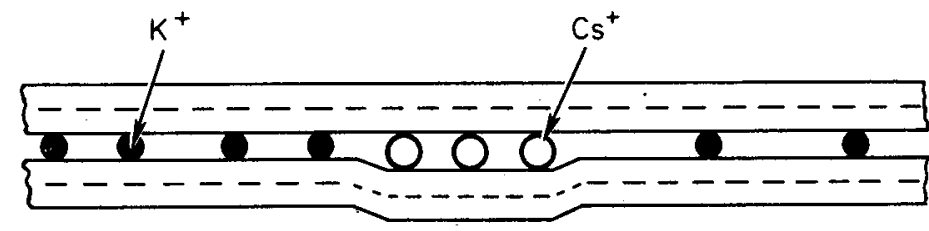

D. Fixed cesium

FIG. C-2 POSSIBLE CONFIGURATIONS OF THE CRYSTAL LATTICE OF MICA MATERIALS 


\section{SOIL PERMEABILITY}

Clay particles normally exist in soil as aggregates; pores between aggregates and other particles are large, and permeability is high. If the clay aggregates become dispersed into smaller particles, soil pores then fill with the smaller clay particles and permeability is reduced. Salts in the high level waste when diluted by ground water can disperse clay aggregates. Undiluted waste does not disperse clay.

The effect of waste salts upon the soil is due to the same phenomena that cause dispersion or flocculation of suspended colloids. ${ }^{11}$ Maximum dispersion occurs in a dilute solution of monovalent cations, and the concentration of cation required to flocculate a colloidal suspension decreases as the valence increases. In SRP soil wetted with ground water, the active cations in the soil water system included $\mathrm{H}^{+}, \mathrm{Na}^{+}, \mathrm{K}^{+}, \mathrm{Ca}^{2+}$, $\mathrm{Mg}^{2+}, \mathrm{Fe}^{3+}$, and $\mathrm{Al}^{3+}$, and the concentrations of divalent and trivalent cations are adequate to prevent clay dispersion. If high level waste, which contains large quantities of sodium ions and free hydroxide, spills into the ground, dispersion will not occur because the high concentration of $\mathrm{Na}^{+}$prevents dispersion, even through $\mathrm{H}^{+}$, $\mathrm{Fe}^{3+}$ (and possibly $\mathrm{Ca}^{2+}$ and $\mathrm{Mg}^{2+}$ ) have been removed from solution and from the soil exchange sites due to neutralization and/or precipitation. As the $\mathrm{Na}^{+}$is diluted to a critical concentration by ground water, the clay aggregate will disperse and soil permeability will decrease.

The effect of simulated waste salts on soil permeability has been studied on several different scales in laboratory experiments. Three experiments were conducted with soil excavated during waste tank construction, and one experiment used undisturbed soil at a test facility located about 10 miles from Tank 16.

- In a laboratory experiment, a 1 -inch permeameter filled with soil that had been dispersed with a dilute solution of $\mathrm{NaOH}$ did not permit any flow of water during a 6 -month period under a hydraulic gradient of 2.9 feet of liquid per foot of soil column.

- In another small scale laboratory test, a soil column 2 inches in diameter and 6 inches deep was treated with simulated waste, and then the permeability to ground water measured. The permeability was $4.6 \times 10^{-6} \mathrm{~cm} / \mathrm{sec}$ as compared to $1.7 \times 10^{-2}$ $\mathrm{cm} / \mathrm{sec}$ in untreated soil. This measured permeability indicates a flow reduction of 3700 resulted from treatment of the soil column with waste followed by ground water inleakage. 
- In a large scale laboratory study, soil columns of about 22-inch diameter and 30 to 60 inches deep were maintained under a constant water head and charged with simulated Purex waste (3.4M $\mathrm{NaNO}_{3} ; 0.55 \mathrm{M} \mathrm{NaAlO} 2 ; 0.35 \mathrm{M} \mathrm{Na}_{2} \mathrm{CO}_{3}, 0.3 \mathrm{M} \mathrm{NaOH}, 0.08 \mathrm{M} \mathrm{Na}_{2} \mathrm{SO}_{4}$ ). Following addition of the simulated waste, the flow decreased rapidly because the sodium ions in the waste, after dilution with water, dispersed the clay aggregate and reduced permeability. The depth of soil with reduced permeability increased as flow continued. (Since the thickness of the zone of reduced flow could not be measured accurately, the apparent permeability was calculated based on the entire soil column.) The apparent permeability coefficient is shown in Figure $\mathrm{C}-3$ as a function of the soil bed volumes of effluent. The data for all permeameters show an inflection at about 0.5 bed volume of effluent-- presumably coincident with removal of the original water. No constant value was reached for the permeability coefficient. (A constant value would correspond to dispersion of all of the clay.)

- In a test to approximate leakage from a waste tank whose bottom is above the water table, simulated Purex waste was added continuously into undisturbed ground through a section of 10-inch diameter pipe extending 4.5 feet below the ground surface. The flow decreased sharply from 64 to $0.16 \mathrm{gallon} /$ day after only 189 gallons of flow. After the first day, the flow could be described by

$$
Q=42 T^{0.22}
$$

where

$Q=$ total volume, gallons

$T=$ time, days

This equation predicts that only 600 gallons would flow from the pipe in 500 years. If flow had been into water-saturated soil, the waste would have become diluted sooner with the resulting dispersion reducing flow from the pipe even more rapidly. The distribution of the salts in the soil as determined by sodium analyses is shown in Figure $\mathrm{C}-4$.

In further tests to define the concentration of waste solution that would disperse the soil, a narrow range for dispersion was defined between dilution factors of 165 and 167; the corresponding concentrations of $\mathrm{Na}^{+}$are 0.0309 and $0.0305 \mathrm{M}$. In other tests, the maximum dispersion occurred at about $0.032 \mathrm{M}$. Therefore dispersion of clay and the resulting decreased permeability occur at the leading boundary where the leaked waste is diluted with surrounding ground water. 


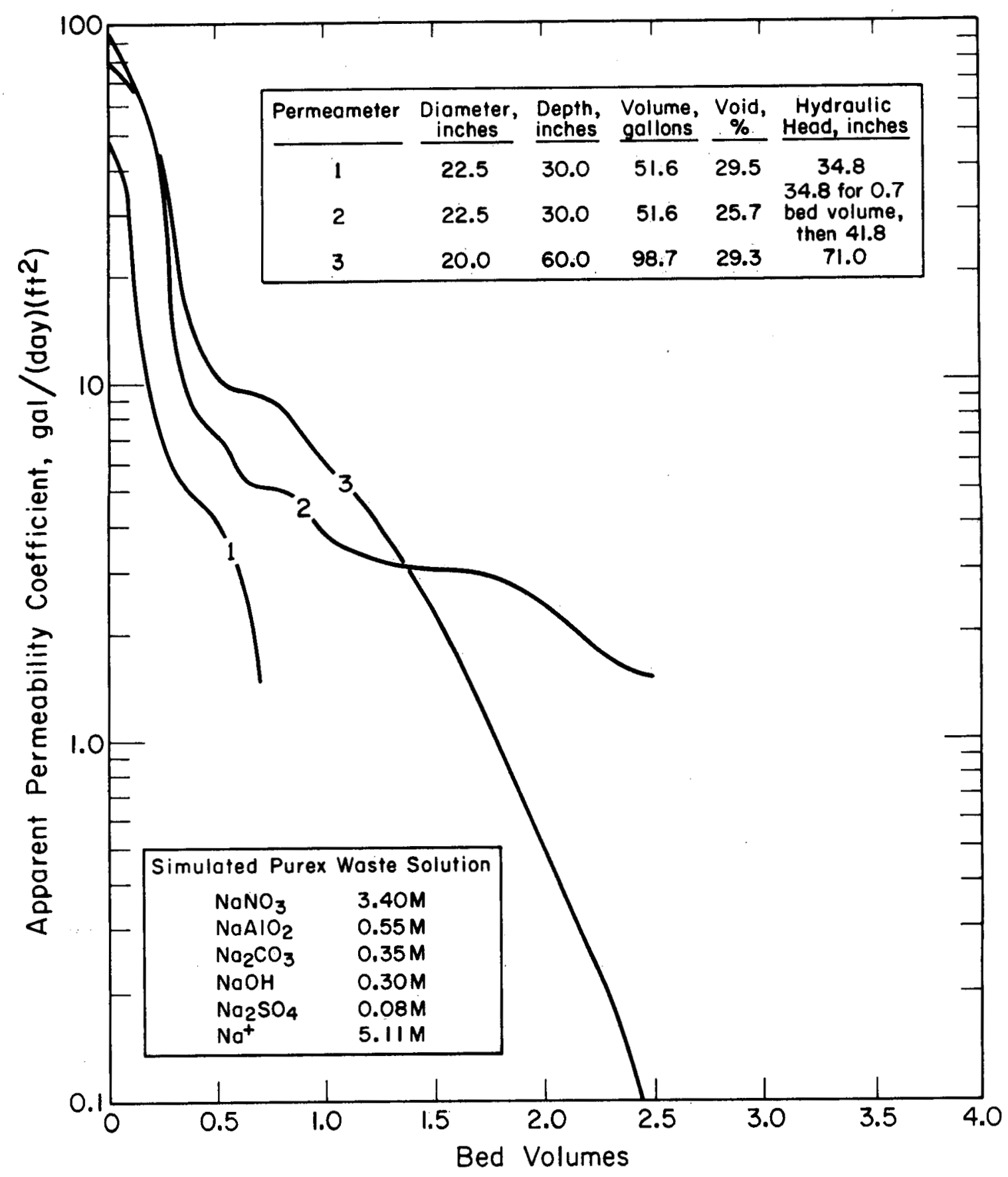

FIG. C-3 MOVEMENT OF SIMULATED WASTE IN SOIL

$$
\text { C-8 }
$$




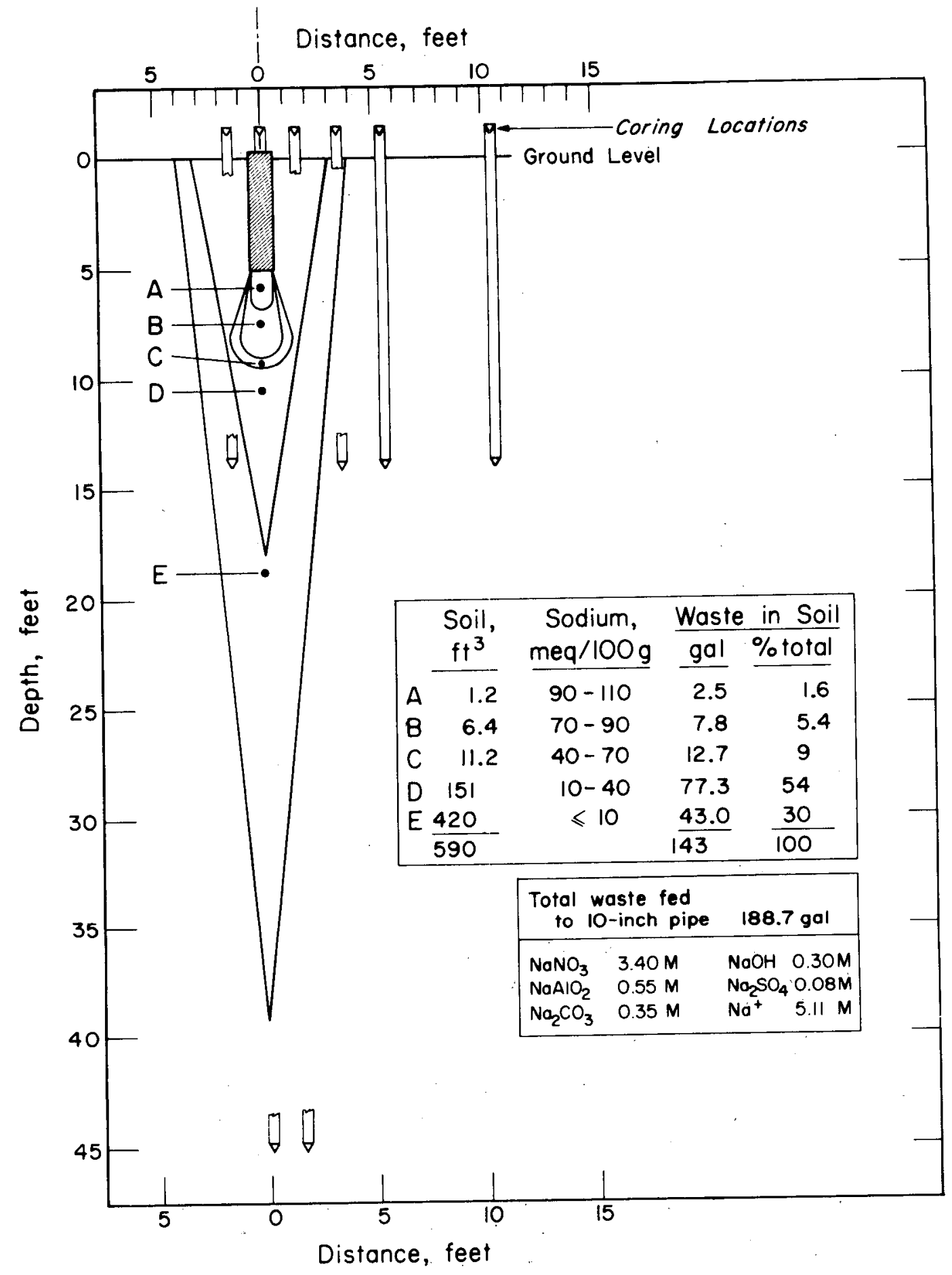

FIG. C-4 PENETRATION OF SOIL BY SIMULATED WASTE 


\section{REFERENCES FOR APPENDIX C}

1. R. E. Grim. Cloy MineraloZogy, p 129, McGraw-Hil1, New York, 1953.

2. W. E. Prout. "Adsorption of Radioactive Wastes by Savannah River Plant Soil." Soil Science, 86.(1), 13 (1958).

3. J. W. Fenimore and J. H. Horton, Jr. "Influence of High Level Waste Salts on Movement of Strontium and Cesium in Savannah River Plant Soi1." USAEC Report DP-1124, E. I. du Pont de Nemours \& Co., Savannah River Laboratory, Aiken, S. C. (January 1968).

4. J. B. Page and L. D. Baver. "Ionic Size in Relation to Fixation of Cations by Colloidal Clay." Soiz Science, Soc. Am. Proc. 4, 150 (1939).

5. J. H. Horton. "The Release and Fixation of Potassium in Fifteen Pennsylvania Soils." PhD Thesis, Pennsylvania State University (1952).

6. G. H. Bolt, M. E. Sumner, and A. Kamphorst. "A Study of the Equilibria Between Three Categories of Potassium in an Illitic Soil." Soil Science, Soc. Am. Proc. 27, 294 (1963).

7. C. I. Rich. "Effect of Cation Size and pH on Potassium Exchange in Nason Soi1." Soil Science, 98, 100 (1964).

8. C. I. Rich and W. R. Black. "Potassium Exchange as Affected by Cation Size, pH, and Mineral Structure." Soil Science, 97, 384 (1964).

9. I. Barshad. "Vermiculite and Its Relation to Biotite as Revealed by Base-Exchange Reactions, $\mathrm{X}$-ray Analyses, Differential Thermal Curves, and Water Content." Am. Mineral. 33, 655 (1949).

10. I. Barshad. "The Effect of the Interlayer Cations on the Expansion of the Mica Type of Crystal Lattice." Am. Mineral. 35,225 (1950).

11. H. Van 0lpnen. An Introduction to Clay Colzoid Chemistry for Clay Technologists, Geologists and Soil Scientists. Interscience Pubs., New York (1963). 


\title{
APPENDIX D
}

\author{
INSPECTION TO ESTABLISH CAUSE OF WASTE TANK LEAKAGE
}

\section{INSPECTION REQUIREMENTS}

Inspection of leaking waste tanks requires use of remote techniques, because of high radiation fields and contamination potential. Inspections of the primary containment waste tanks are normally from the outside of the tank (viewing it through the annular space). These include visual inspection made with periscope, direct camera photography, ultrasonic measurement of wall thickness, and use of corrosion specimens (including excision of a portion of a tank). Inspections of the interior wall of the tanks have utilized some of the same general techniques, but have not been made to the same extent as exterior wall inspection since the field of view is much more limited. This appendix describes tank inspections as they relate to Tank 16.

\section{INITIAL INSPECTIONS}

Though Tank 16 was not the first tank to leak, it was the first tank where the source of leakage could be seen below one of the four annulus access ports. An initial inspection was made in November 1959 using a mirror lowered into the annulus and a telescope mounted on top of the tank for magnification. Seven separate salt protuberances were observed along the horizontal welds 30 inches above the bottom of the tank. Photographs of the leak sites on the tank wall that were made by using mirrors were unsatisfactory. Figure A-1 of Appendix A is representative of the best of the photographs obtained.

In early 1960, a television camera was lowered into the annulus. Photographs of the monitor screen (Figure A-2 of Appendix A is a typical photograph) confirmed the areas of leakage observed earlier with the mirror-telescope. Comparing these TV pictures with Construction x-rays of welds (Figure A-3 of Appendix A), the leakage appeared to occur at patch areas in seam welds between lower knuckle and side wall plates. (The x-rays showed that the patches in the weld had been satisfactorily made.) Viewing of the tank with the television was discontinued due to mechanical difficulties. 
INSPECTION EQUIPMENT

By January 1961, equipment had been fabricated to support a television camera directly below existing access ports to the annulus. This camera could be turned $360^{\circ}$ horizontally and $180^{\circ}$ vertically and positioned to view a 6 -inch strip of the tank wall about four feet wide.

In addition, a 40-foot long periscope was purchased which could be lowered through a 7-3/4-inch-diameter hole. This required removal only of an instrument plug rather than the 30-inch-diameter annulus access port plug. Approximately 7-1/2 feet of the tank wall on either side of the entrance hole could be viewed or photographed with an attached camera.

\section{1-1962 GENERAL INSPECTION}

Tank 16 side wall inspections made in 1961 and 1962 indicated 134 leak sites on the area inspected. Approximately $73 \%$ of the tank wall could be inspected. Crusts of salt trailing downward from well-defined spots indicated positions of leaks. Most of these were near welds between plates. Later studies with a reflectoscope indicated that cracks not near visible welds were probably near welds on the interior of the tank.

Figure D-1 is an elevation view of the outside wall of Tank 16. The location of each significant leak is indicated by a spot and tail that roughly portray the appearance of the leak.

\section{GENERAL INSPECTION}

A comprehensive inspection program of Waste Tank 16 was again undertaken in 1971. This survey indicated the tank contained an estimated 350 leak sites. An exact count of leak sites was not feasible due to larger salt deposits obscuring the smaller ones. A summary of this inspection indicated:

- Salt deposits on the walls at previously observed leak sites were thicker than before, indicating seepage during at least part of the previous ten-year period. Increased amount of salt in the annulus pan was also evident.

- Additional leak sites were visible in the 1972 photograph. Figures D-2 and D-3 show typical leakage in 1962 and 1972. These photographs were of the same section of the tank.

- Wall thickness measurements have not been made on Waste Tank 16 but have been made on other tanks of similar construction and containing similar waste. The measurements indicate no significant thinning of the tank walls. The devices used do not detect small pits or thin cracks.

$$
\mathrm{D}-2
$$




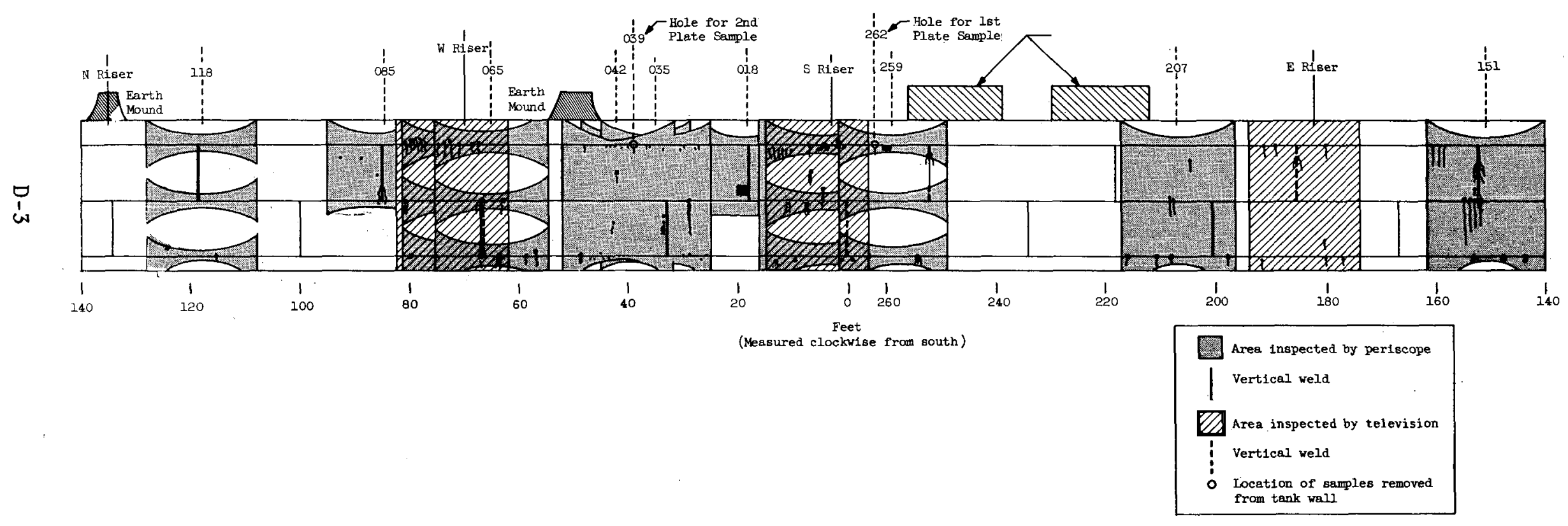

FIG. D-1 FACE MAP OF TANK 16 WALL (1962 INSPECTION) 


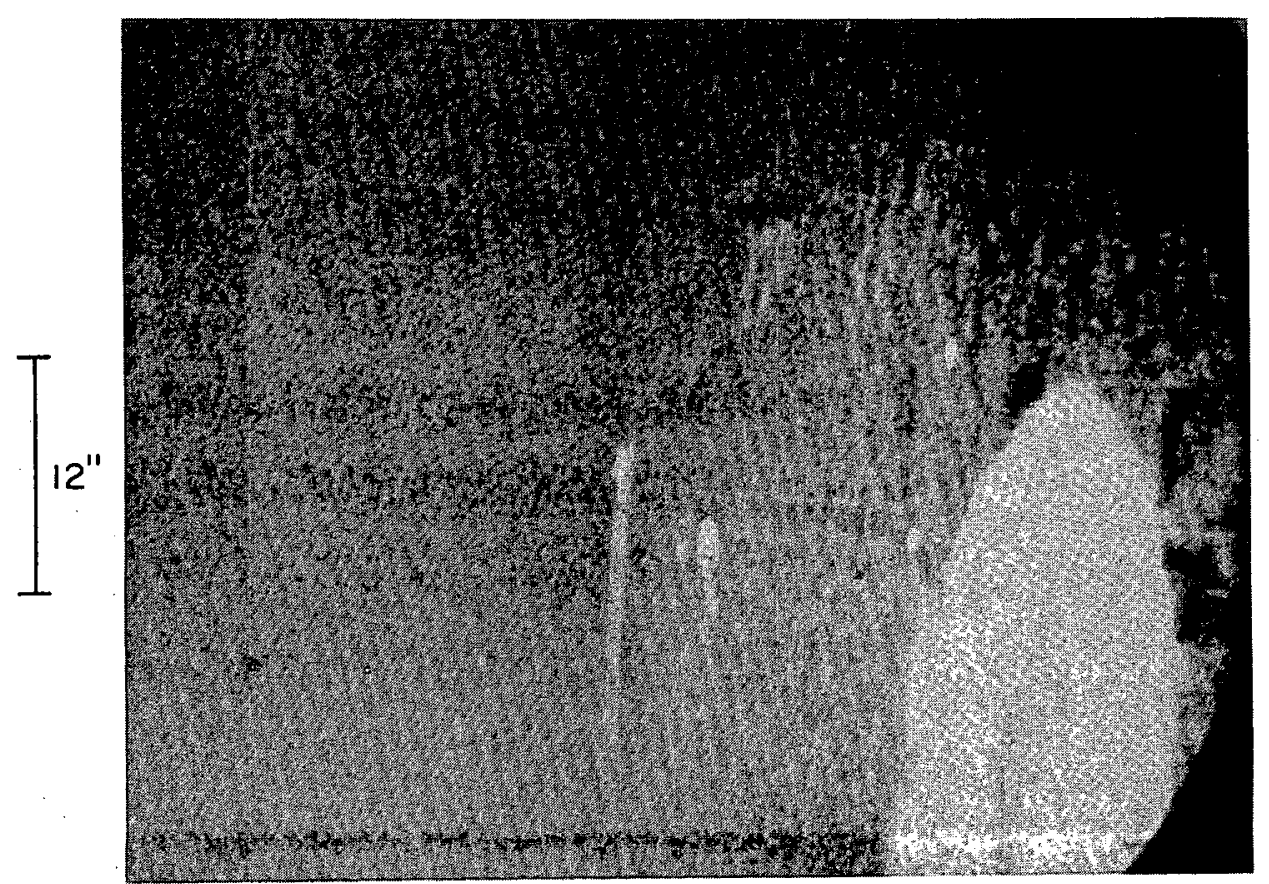

FIG. D-2 TANK 16 PRIMARY WALL, BY PERISCOPE, 1962 Shows leakage at lowest horizontal seam weld.

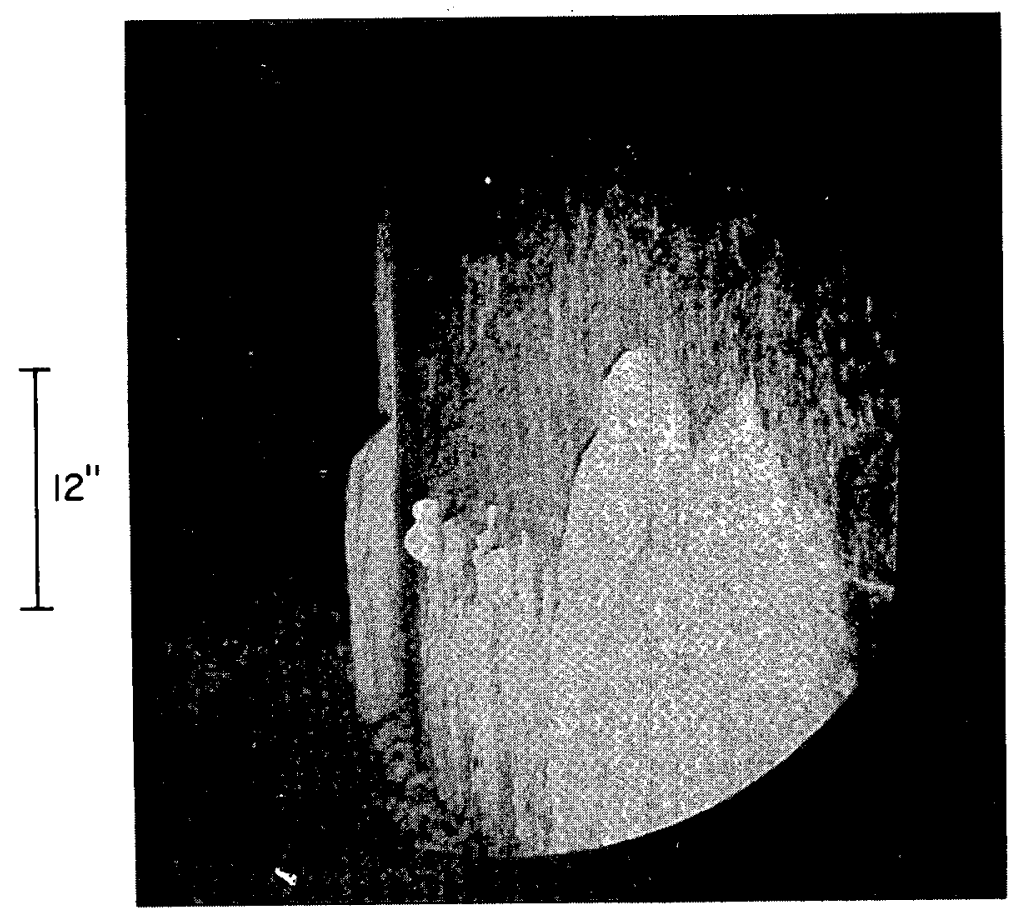

FIG. D-3 TANK 16 PRIMARY WALL, BY PERISCOPE, 1972 Enlarged deposits and additional leak sites compared to 1962 photograph. 
Examination of the tank wall revealed the number and location of the leaks, but very little about the leaks themselves. More information was obtained, first by washing the accumulated salts from an individual leak and removing the rust by sandblasting while observing and photographing the leak area through the periscope after each operation. As shown in Figure D-4, there were definite cracks under the salt deposit.

Figure D-5 shows a summary of both visual and photographic inspections of the sandblasted vertical weld near Hole 151 of Tank 16. Ten sizeable cracks were observed, four of which were 4 to 6 inches long. Figure D-5 also shows the surface imperfections visible through the periscope and discernible on the $x$-rays of the weld: internal and external weld beads, and the punch marks used as x-ray reference marks. Although three of the cracks appear to be located near these weld beads, most of the cracks show no correlation with known fabrication blemishes. All of the cracks are in areas likely to be affected by stresses caused by making the seam welds. Photographs of one of the large cracks are shown in Figures $\mathrm{D}-6, \mathrm{D}-7$, and $\mathrm{D}-8$.

A sample of the tank wall was removed in October 1961 for metallographic examination. This sample, a plate 5-5/8 inches in diameter, was removed through the annular space, using a cutter head that retained the cut-out sample with magnets. The location of the sample, selected to include two previously observed leaks, is shown in Figure D-1. Prior to the removal, this area had been sandblasted and showed cracks where there had been deposits. The sample was centered approximately on the weld between the top knuckle and shell plates.

Because of the radioactive contamination of the sample, most of the examination was conducted in the high level caves at the Savannah River Laboratory. Examination of the specimen prior to cleaning revealed three cracks, two of which completely penetrated the 5/8-inch thick disk. The cracks were essentailly perpendicular to the tank girth weld and probably started on the inner surface. Two cracks could be seen on the exterior surface of the specimen, but a tightly adherent brown deposit obscured all minor details of the interior surface. Attempts to remove the surface layer by mechanical methods were not successful, primarily because of the magnetism in the sample that resulted from the use of magnets during its removal from the tank. Most of the coating on the inner surface was finally removed by briefly dipping the specimen in inhibited hydrochloric acid. The cracks in the specimen are highlighted on Figure D-9 by the arrows. 

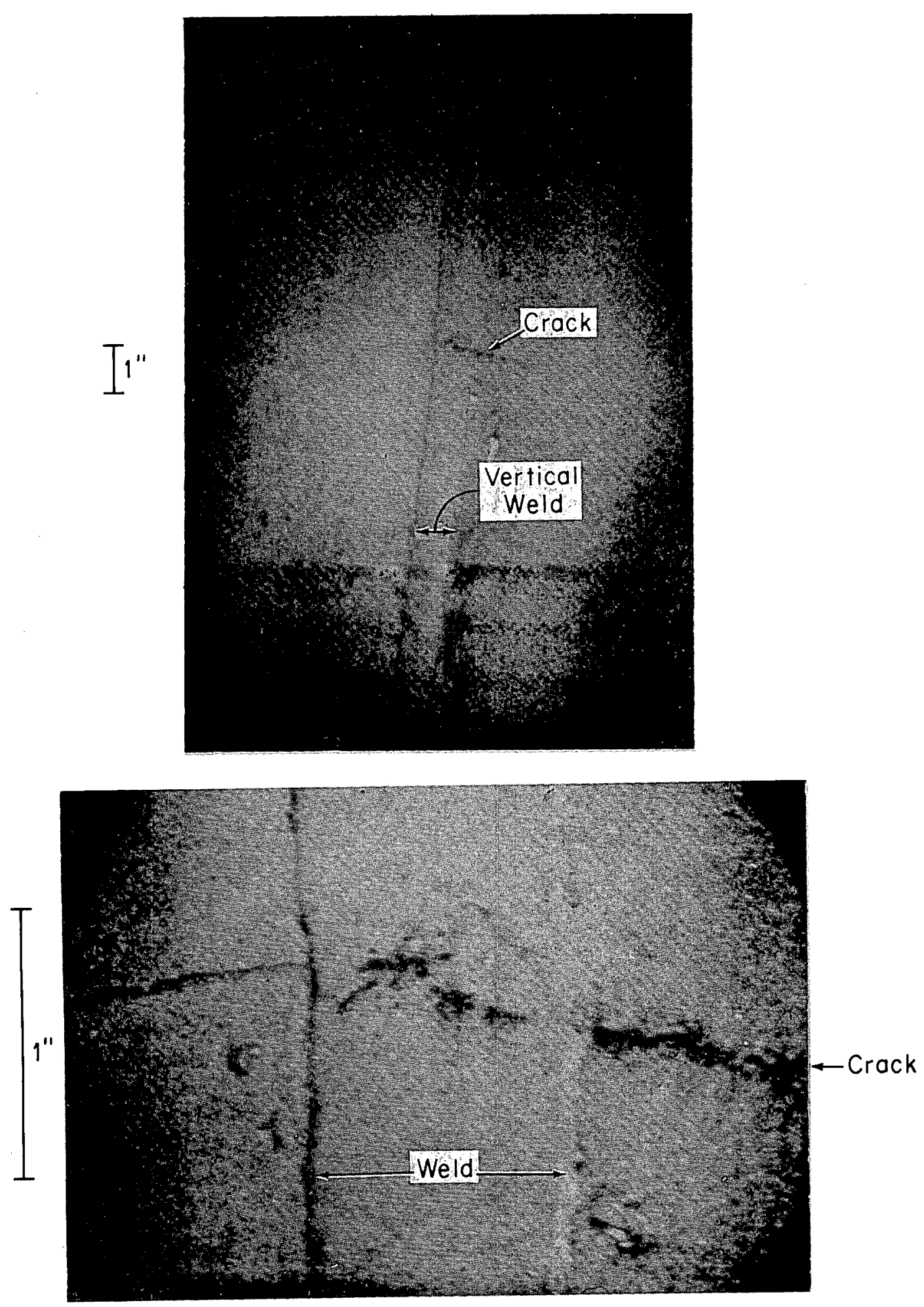

FIG. D-4 LEAK POINT IN A VERTICAL SEAM WELD OF TANK 16 PRIOR TO SANDBLASTING

$$
\text { D-6 }
$$




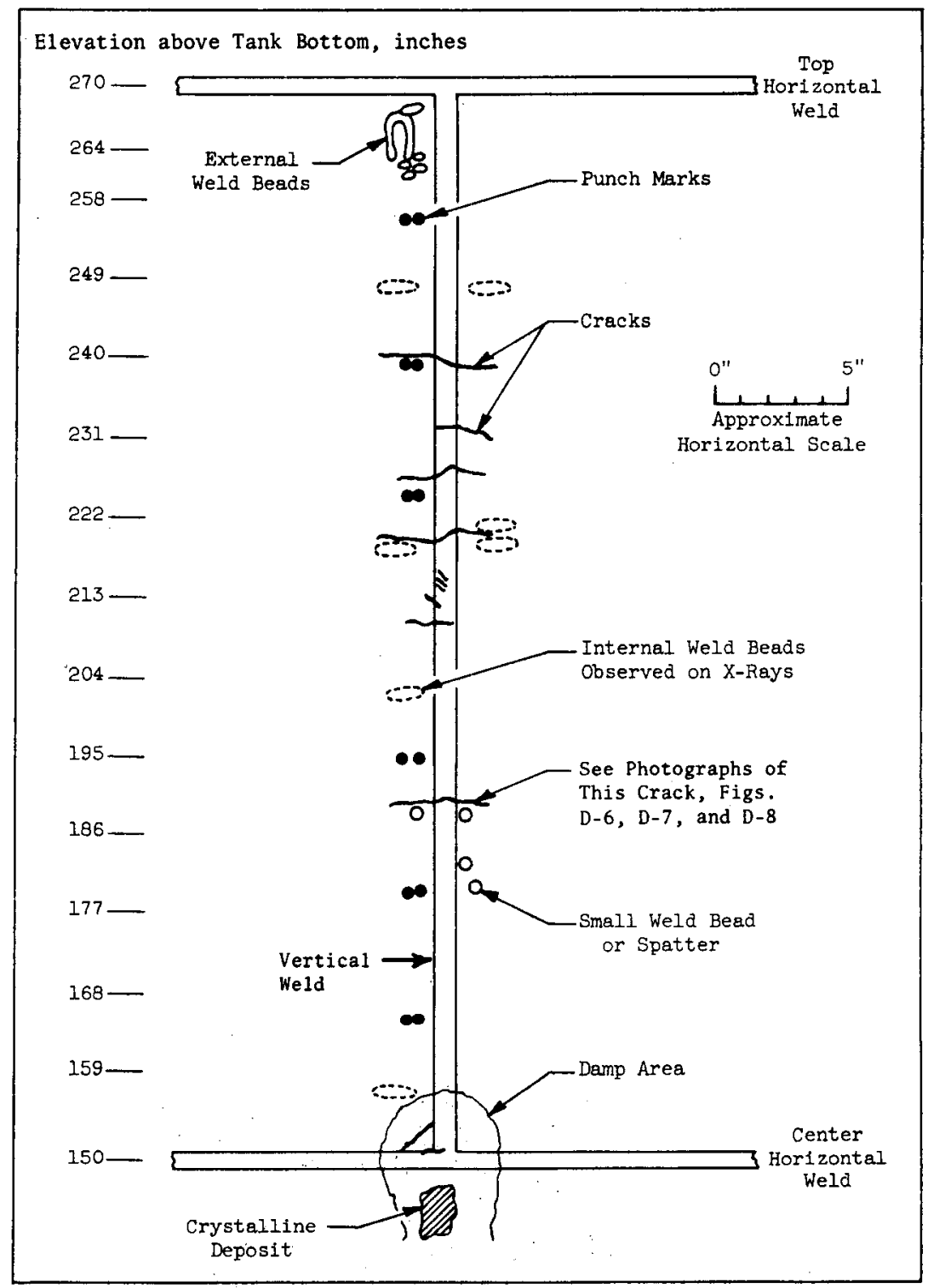

FIG. D-5 PERISCOPE INSPECTION OF SANDBLASTED VERTICAL WELD, ACCESS HOLE 151 


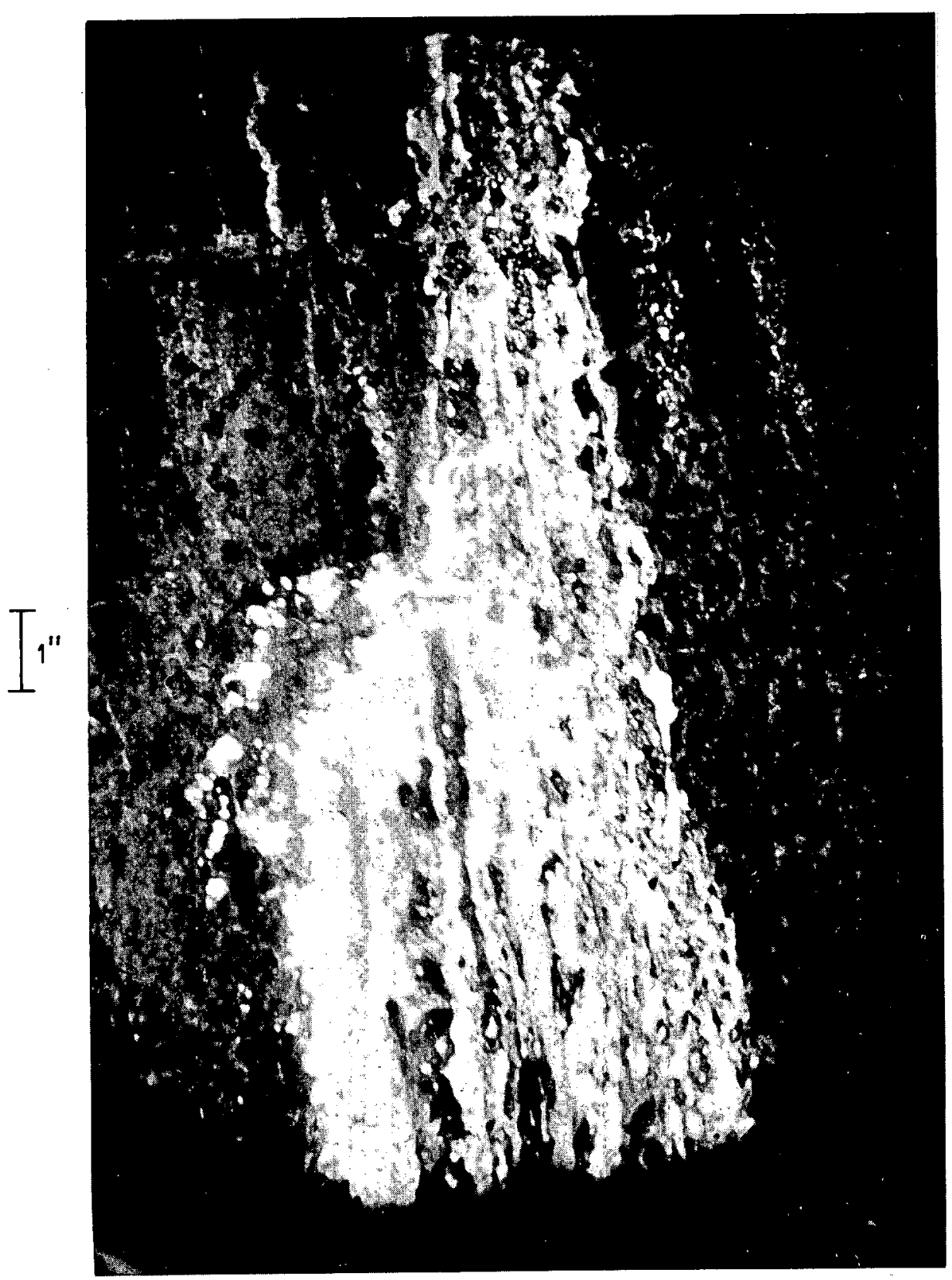

FIG. D-6 - LEAK DEPOSITS AROUND CRACK ACROSS VERTICAL WELD 190" above tank bottom, viewed through Access Hole 151 . 


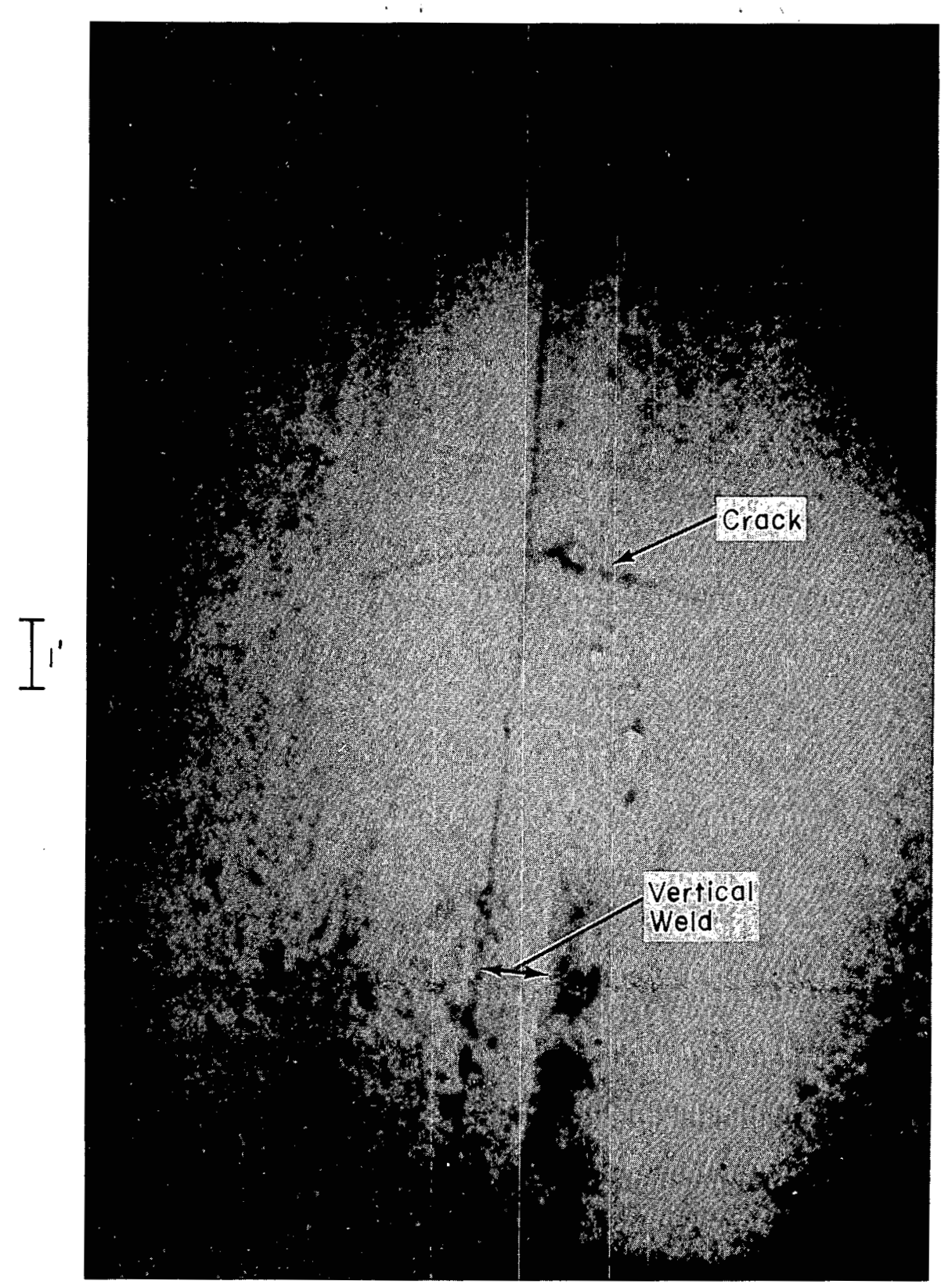

FIG. D-7 SAME AREA AS FIGURE D-6, AFTER SANDBLASTING 


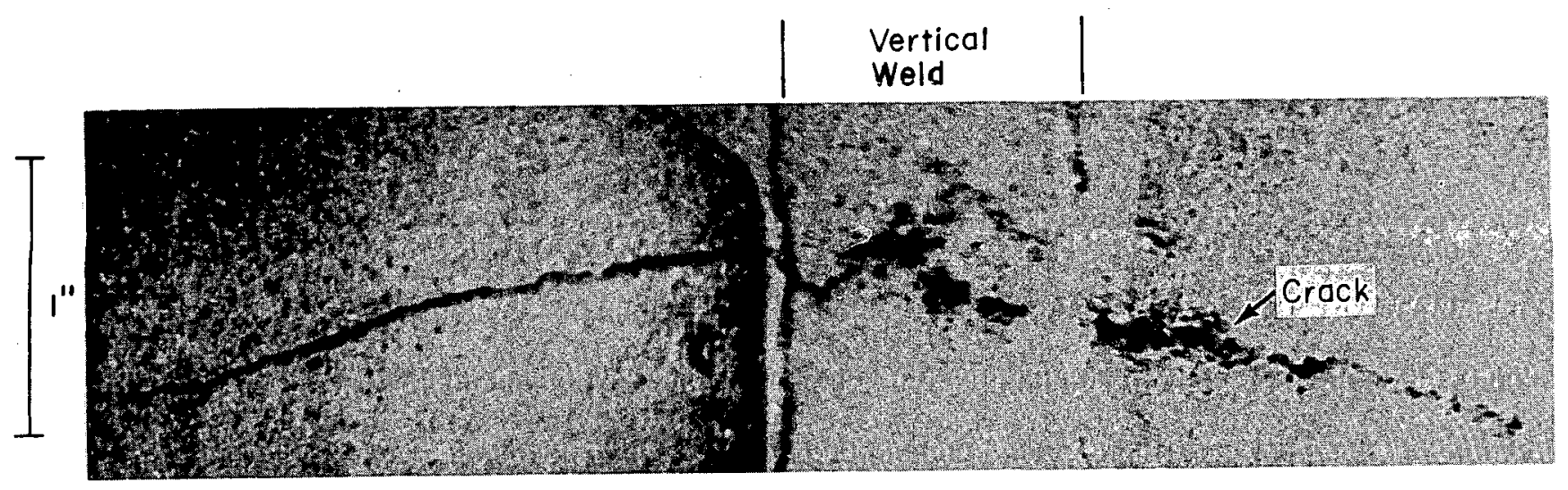

FIG. D-8 COMPOSITE PHOTOGRAPH OF CRACK SHOWN IN FIGURE D-7 


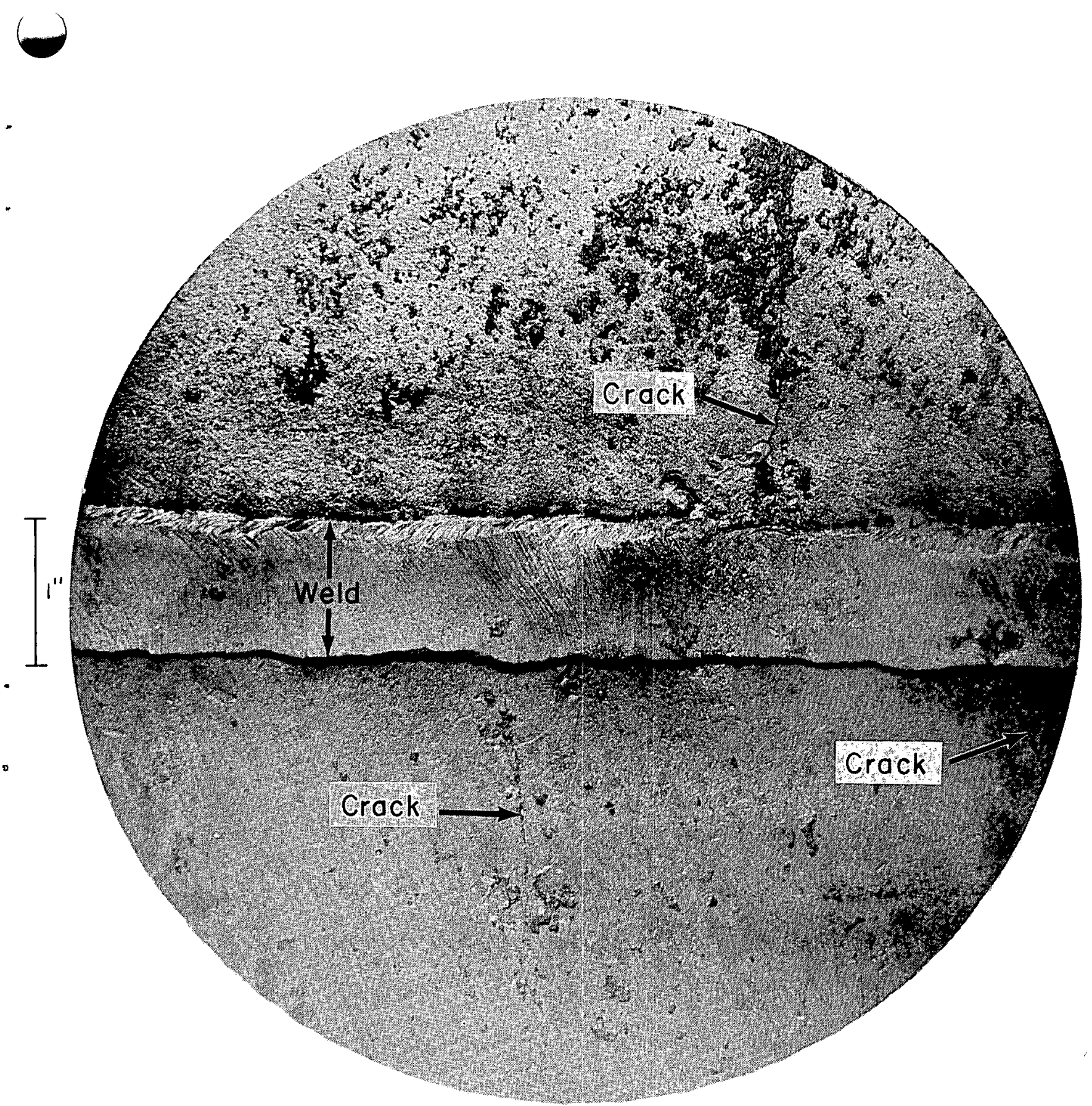

FIG. D-9 SAMPLE REMOVED FROM WALL OF TANK 16

(Interior surface after sample was cleaned) 
A second sample, 5-5/8 inches in diameter, centered approximately on the weld between the top knuckle and side-wall plate, was removed from the tank at a known leak point 45 feet from the first sample (see Figure D-1). This sample had the same characteristics with respect to cracking as the first sample, so it was concluded that representative samples of the failures in Tank 16 had been obtained.

Chemical analyses of the knuckle and side-wall plates from the sample agreed with mill-test reports submitted by the tank erector; they were within the limits specified for A.S.T.M. A-285 Grade B firebox quality steel. Compositions of the weld material and plate material were essentially the same.

Good ductility was demonstrated by bend tests performed with strips cut from the decontaminated portion of the sample.

Very little general corrosion of the inner surface occurred during the seven months in which waste solution was in contact with the steel and the much longer periods in which the tank was empty or partially filled. Grinding marks that were made when the tank was erected are visible on the weld. Shallow pitting, about 0.020 inch deep, occurred at several locations.

Al1 cracks were intergranular (Figure D'-10). One crack in the knuckle plate appeared to originate adjacent to the arc strike. Figure D-11 shows a cross section through this arc strike. Neither of these two major cracks propagated into the weld.

Numerous small cracks were observed on the inner surface. These cracks, shown in Figure D-12, were located in both the knuckle and side-wall plates in bands about $1 / 2$ inch wide. The edge of these bands was located between $1 / 16$ and $1 / 8$ inch from the edge of the weld. The cracks ranged from $1 / 16$ to $1 / 2$ inch in length and the deepest ones were removed by grinding about $1 / 32$ inch from the surface. 


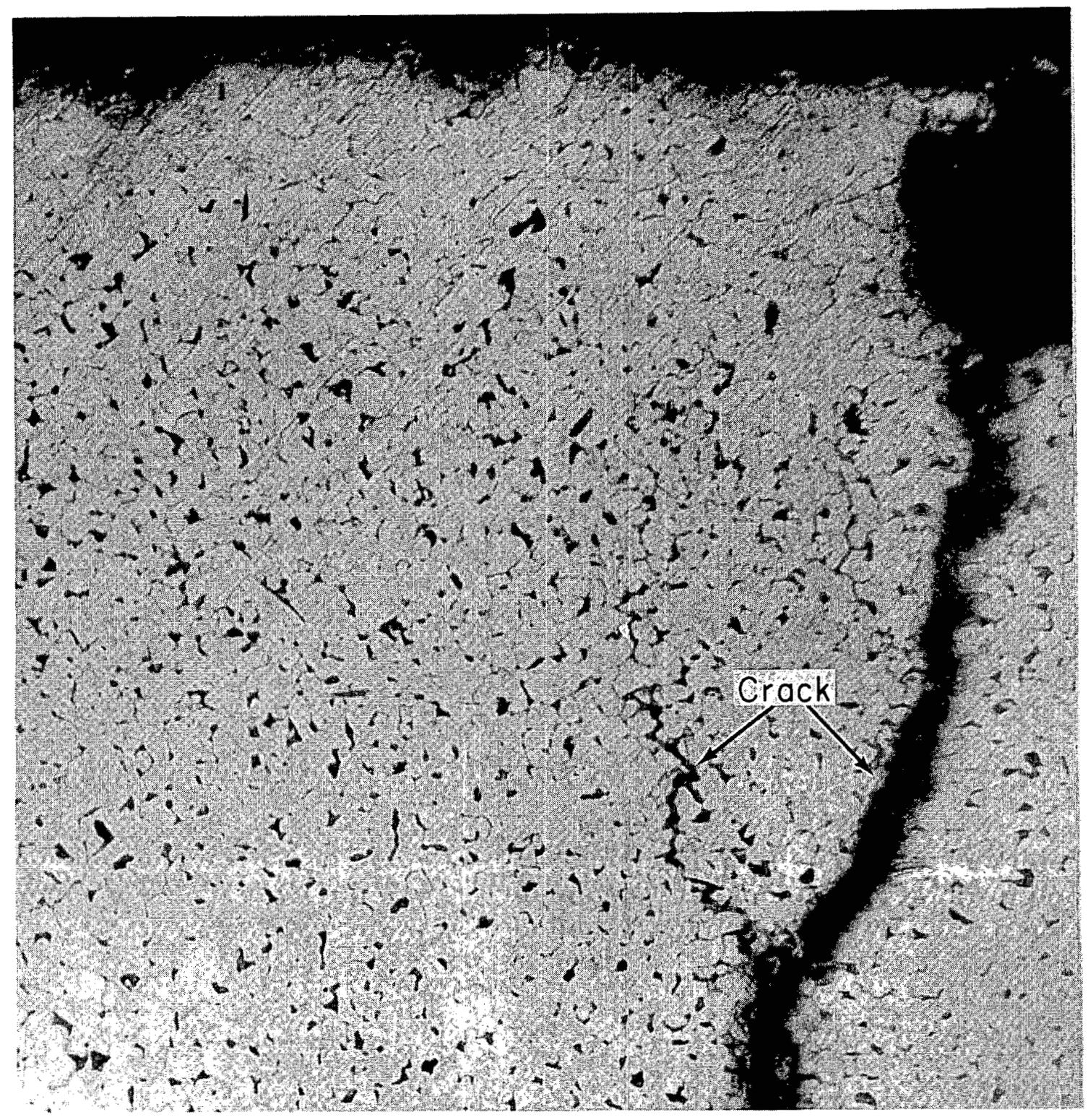

FIG. D-10 PHOTOMICROGRAPH OF SAMPLE FROM WALL OF TANK 16 Approximately $130 \mathrm{X}$ 


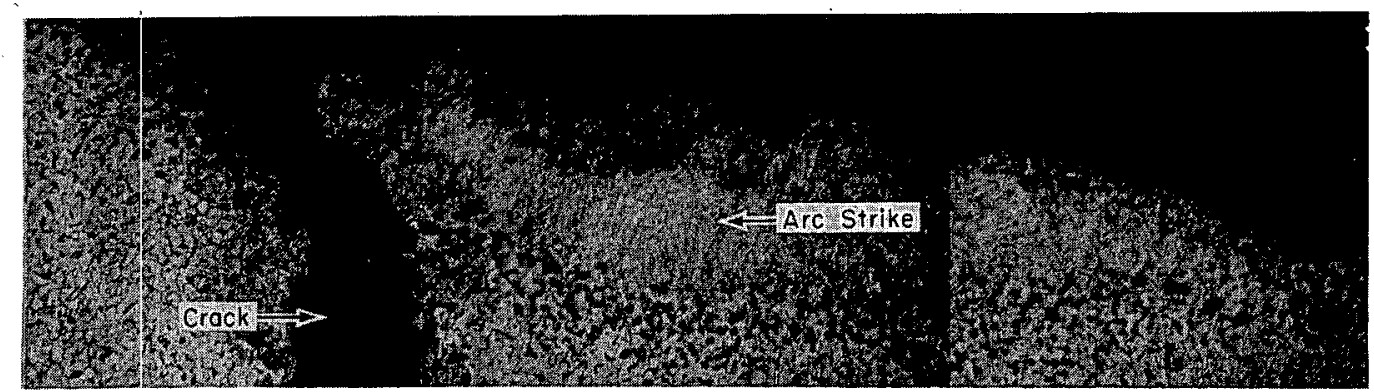

FIG. D-11 PHOTOMICROGRAPH OF SAMPLE OF TANK 16 WALL SHOWING AREA NEAR ARC STRIKE

Approximately $23 X$

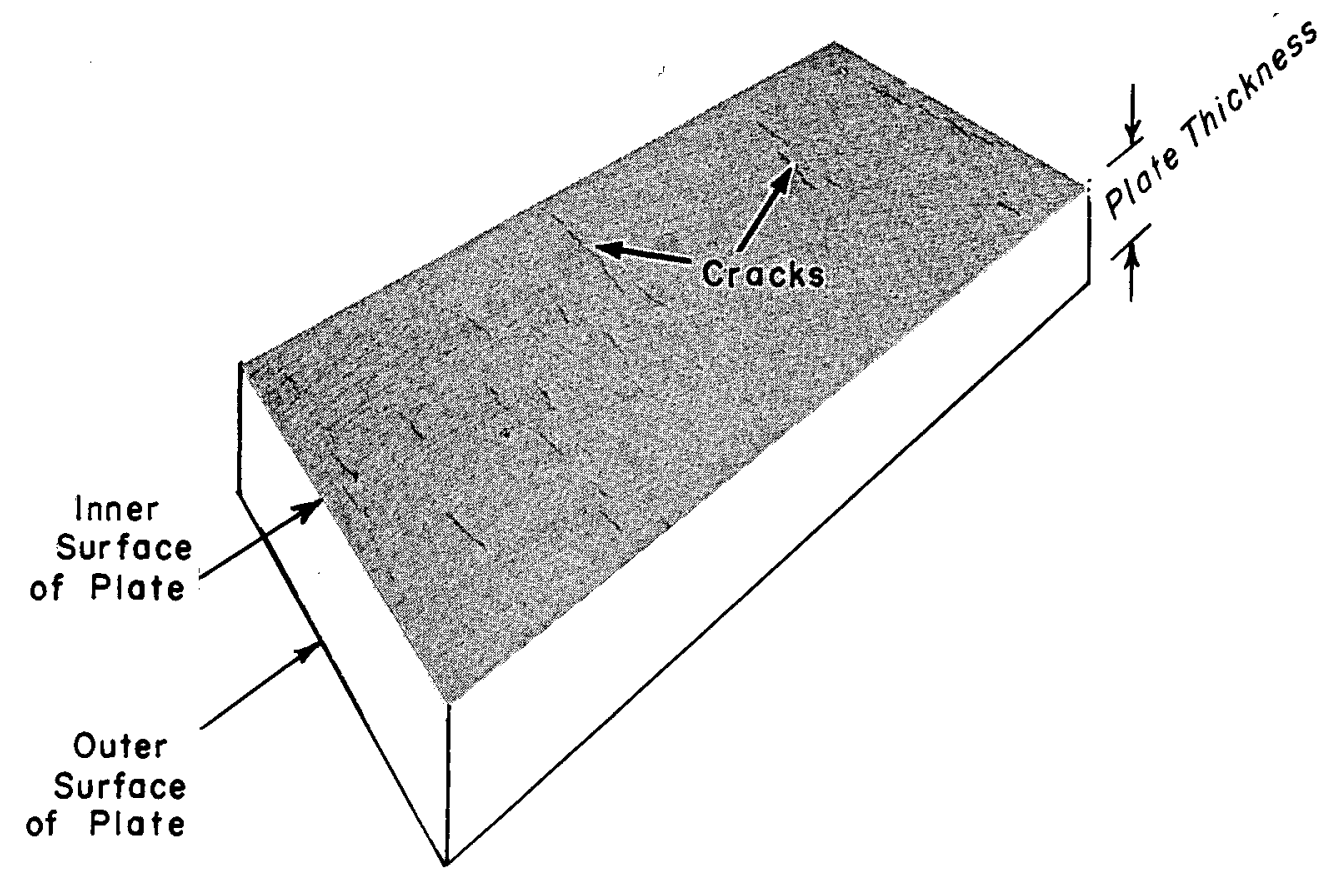

FIG. D-12 PHOTOGRAPH OF SAMPLE OF TANK 16 WALL SHOWING NUMEROUS CRACKS ON INNER SURFACE Approximately $2 X$ 


\section{CAUSE OF LEAKS}

The observations described lead to the conclusion that Tank 16 leaked because of the development of numerous cracks on the inner surface of the tank. Some of these cracks penetrated the plate, and were large enough to pass liquid when under hydrostatic pressure.

Stress corrosion cracking is the most likely cause of the leaks in Tank 16 since the following characteristics of stress corrosion cracking of carbon steel were present:

- The cracking was intergranular.

- The leaks occurred near welds where large residual stresses would be expected from thermal effects during welding.

- The stressed steel was exposed to an aqueous solution containing considerable sodium nitrate and sodium hydroxide, agents known to promote stress corrosion cracking.

An extensive laboratory program showed that stress corrosion cracks developed in steel plate similar to that used in Tank 16 when exposed to waste solutions chemically similar to those in Tank 16. 


\section{APPENDIX E \\ WATER TABLE ELEVATION}

Water table levels measured in the vicinity of Waste Tank 16 are shown in Figure E-1. As can be seen, the frequency of data collection varied over the period of collection. Water table levels were measured in Well 1 (Figure E-2) until We11 49 was installed in December 1960. Since then, all water table levels reported are from Well 49.

The water table level has been measured only sporadically since 1967. The curve given on the lower half of Figure E-1 is an interpolation curve and anchored to measured points. The normal seasonal variations for this interpolation were obtained from 1961 through 1963. The annual rainfall seems to bear out the interpolation.

The rainfall for 1958 through 1960 was measured in the 700 Area ( $\left(6 \frac{1}{2}\right.$ miles from Tank 16), and later values were measured in $F$ area ( 2 miles from Tank 16).

The elevations of several construction features of Waste Tank 16 are also given on Figure E-1 for reference. The dashed lines shown at 270.3, 274, and 279 feet are the levels of the concrete construction pad, the level of the bottom of the tank, and the elevation of the top of the steel annulus pan (also the construction joint in the concrete encasement), respectively. Several key historical factors relating to Tank 16 are also given on Figure E-1.

The water table has been higher than the annulus pan rim and construction joint at least six times since 1958. On one of these occasions (March 1964 to May 1965), it remained above the rim and joint for all but one month in a thirteen-month period so that inleakage could easily have occurred if a path exists. The water table has fallen below the tank bottom twice since 1958, but has never dropped below the construction pad. At the time of the annulus pan overfill, the water table was 2.9 feet below the rim of the annulus pan. 


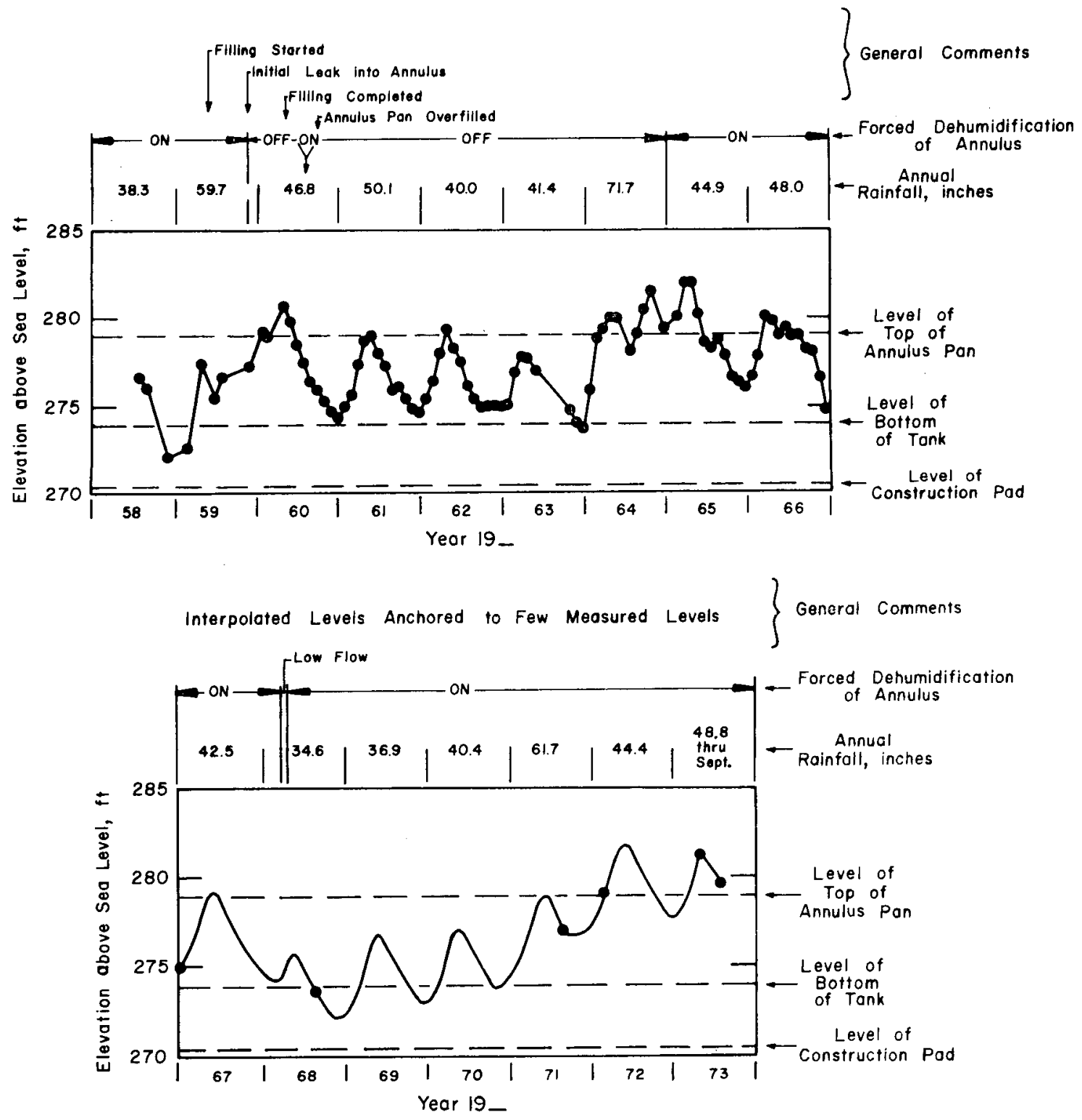

FIG. E-1 WATER TABLE LEVEL AROUND WASTE TANKS

E-2 


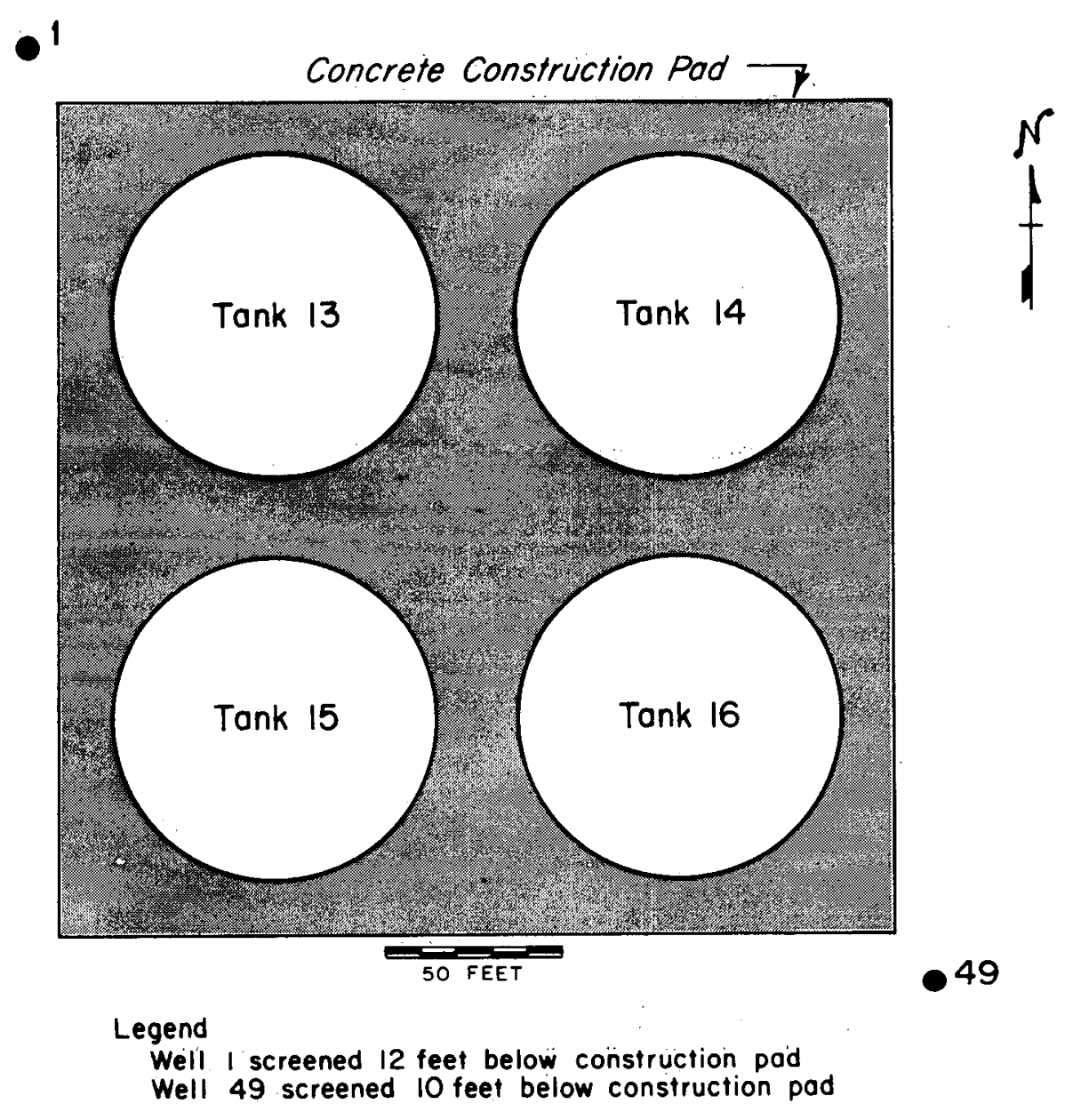

FIG. E-2 WATER TABLE LEVEL MEASURING WELLS 


\section{APPENDIX $F$ \\ REVERSAL OF GROUND WATER GRADIENT}

Tests were made to demonstrate that a local depression in the level of the ground water could be created. This depression would direct all ground water flow to the depression and prevent spilled radionuclides in the ground water from migrating from the area of the spill. The water addition system under Tank 16 was used as a pump field from which water was removed at 4 gallons/min during 1961 to 1963 . This low pump rate reversed the water table gradient so that flow was toward and not away from the water addition system. In this study, water level measurements were made in Wells 59. and 61 through 64 (Figure F-1), which form a line down the water table gradient from Riser 5 of the water addition system and extending across the edge of the concrete construction pad. The reversal of the gradient was most readily demonstrated by comparing the elevations in Well 59 (15 feet from the edge of the concrete pad) and We11 64 (76 feet from the concrete pad).

\begin{tabular}{llrll} 
& & \multicolumn{2}{l}{ Water Table Elevation, ft } \\
\cline { 5 - 5 } & & Pump & We1159 & We1164 \\
\cline { 3 - 4 } $9 / 15 / 61$ & $-9 / 22 / 61$ & OFF & 276.2 & 275.0 \\
$9 / 25 / 61-10 / 24 / 61$ & ON & 275.1 & 275.4 \\
$11 / 6 / 61$ & $-11 / 20 / 61$ & OFF & 275.0 & 274.8 \\
$12 / 13 / 61-12 / 18 / 61$ & ON & 275.1 & 275.5 \\
$12 / 19 / 61-1 / 23 / 62$ & OFF & 276.0 & 275.8 \\
$1 / 31 / 63$ & $-2 / 20 / 62$ & ON & 276.1 & 277.8 \\
$3 / 5 / 62$ & $-3 / 22 / 62$ & OFF & 279.1 & 278.6 \\
$4 / 24 / 62$ & $-4 / 30 / 62$ & ON & 279.2 & 280.0 \\
$5 / 1 / 62$ & $-5 / 7 / 62$ & OFF & 279.4 & 279.0 \\
$5 / 8 / 62$ & $-5 / 14 / 62$ & ON & 278.3 & 278.4 \\
$5 / 15 / 62$ & $-5 / 21 / 62$ & OFF & 279.0 & 278.6
\end{tabular}

a. Above mean sea level.

When the pump was off, the elevation of the water table was higher in We11 59 than in Well 64 so that flow was away from the concrete pad. When the pump was on (and equilibrium established), the elevation of the water table was higher in We1l 64 than in We11 59 so that ground water flow was toward the concrete pad. 


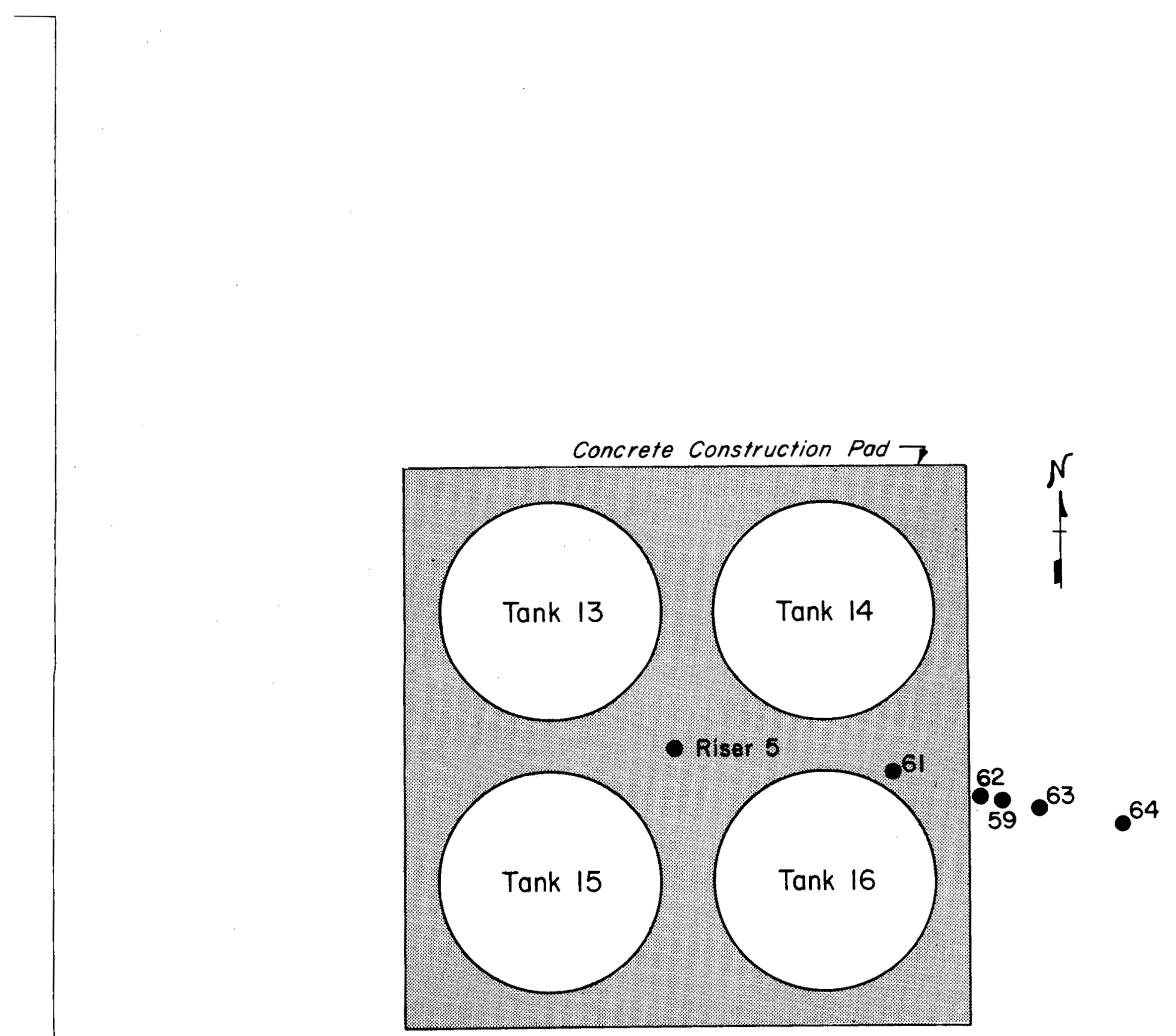

FIG. F-1 LOCATION OF GROUND WATER LEVEL MONITORING WELLS 